\title{
Ruthenium- and Cobalt-Catalyzed C-H Activation
}

\author{
Dissertation \\ for the award of the degree \\ "Doctor rerum naturalium" \\ of the Georg-August-Universität Göttingen
}

within the doctoral program of chemistry

of the Georg-August University School of Science (GAUSS)

Submitted by

Qingqing Bu

From Xinxiang (China)

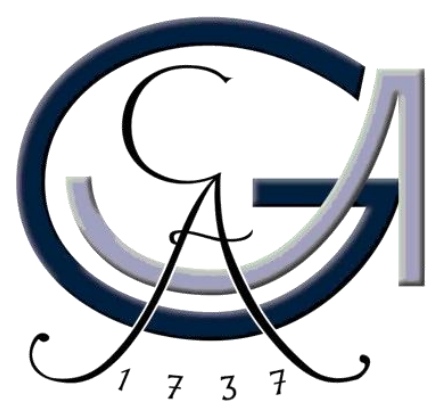

Göttingen, 2018 


\section{Thesis Committee}

Prof. Dr. Lutz. Ackermann, Institute of Organic and Biomolecular Chemistry

PD Dr. Alexander Breder, Institute of Organic and Biomolecular Chemistry

\section{Members of the Examination Board}

Reviewer: Prof. Dr. Lutz. Ackermann, Institute of Organic and Biomolecular Chemistry

Second Reviewer: PD Dr. Alexander Breder, Institute of Organic and Biomolecular Chemistry

\section{Further Members of the Examination Board}

Prof. Dr. Dr. h.c. Lutz-F. Tietze, Institute of Organic and Bimolecular Chemistry

Prof. Dr. Dietmar Stalke, Institute of Inorganic Chemistry

Dr. Franziska Thomas, Institute of Organic and Bimolecular Chemistry

Dr. Shoubik Das, Institute of Organic and Biomolecular Chemistry

Date of the oral examination: 30. 10. 2018 


\section{Contents}

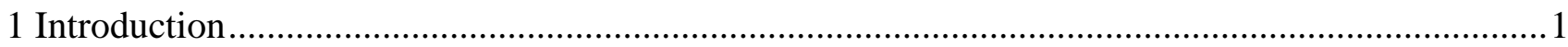

1.1 Transition Metal-Catalyzed C-H Functionalizations ...................................................... 1

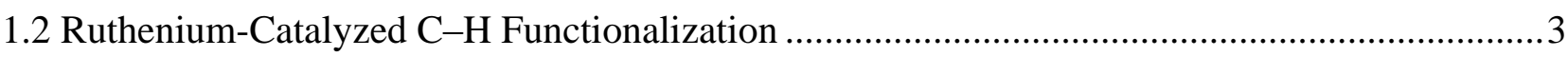

1.2.1 Ruthenium Catalyzed C-H Alkenylation ................................................................. 4

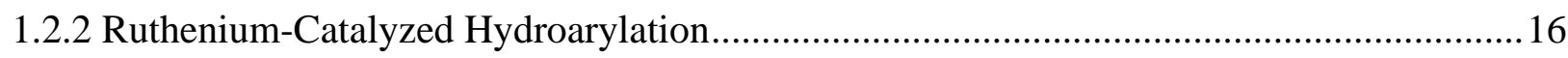

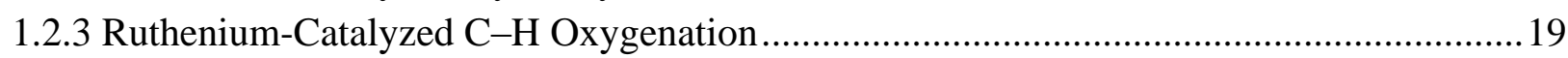

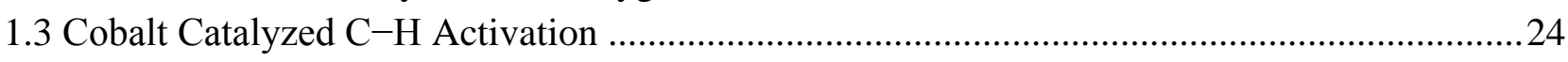

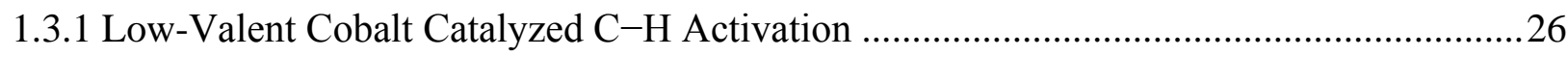

1.3.2 High Valent Cobalt(III)-Catalyzed C-H Activation .................................................... 32

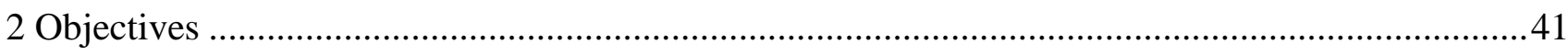

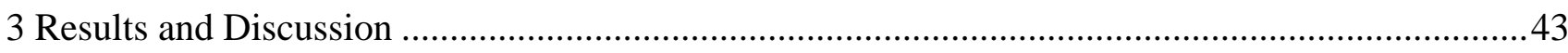

3.1 Distal Weak Coordination of Acetamides in Ruthenium(II)-Catalyzed C-H Activation..........43

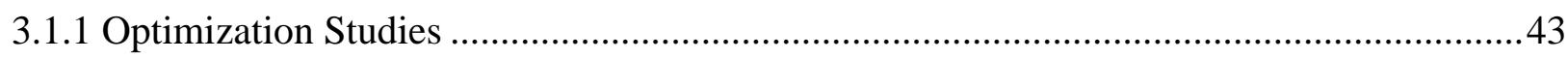

3.1.2 Scope of Ruthenium(II)-Catalyzed C-H Alkenylation ...............................................45

3.1.3 Weak $O$-Coordination for $\mathrm{C}-\mathrm{H}$ Activation/Alkyne Hydroarylation .................................48

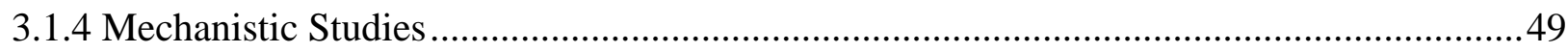

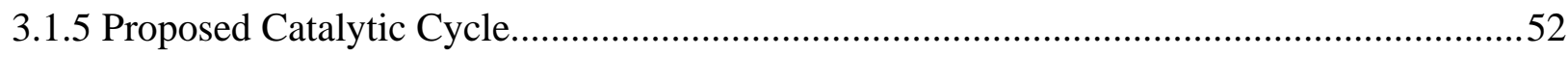

3.2 Ruthenium(II)-Catalyzed C-H Oxygenation of Weakly-Coordinating ...................................54

3.2.1 Optimization Studies for Ruthenium(II)-Catalyzed C-H Oxygenation............................54

3.2.2 Scope of Acetamides in Ruthenium(II)-Catalyzed C-H Oxygenation ............................56

3.3 Low-Valent Cobalt-Catalyzed C-H Arylation ..............................................................5

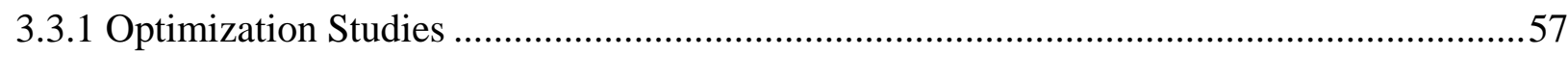

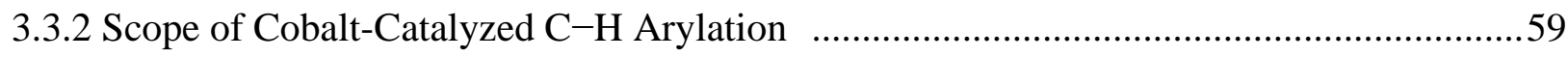

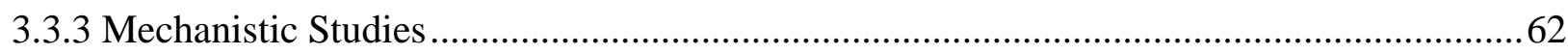

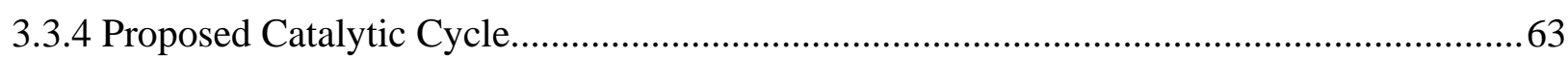

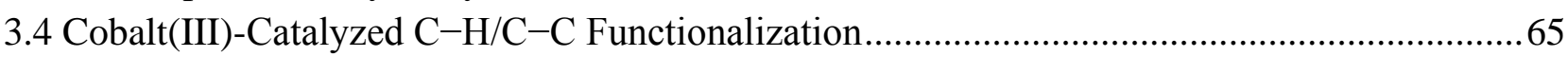

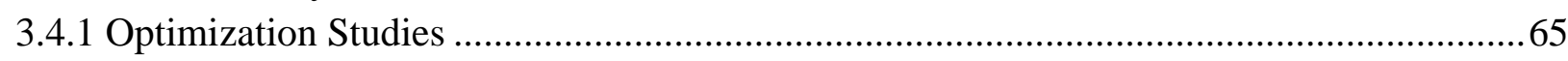

3.4.2 Scope of the Cobalt(III)-Catalyzed C-H/C-C Functionalization....................................66

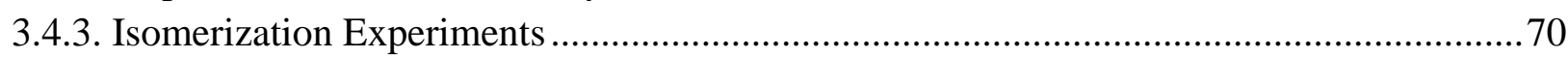

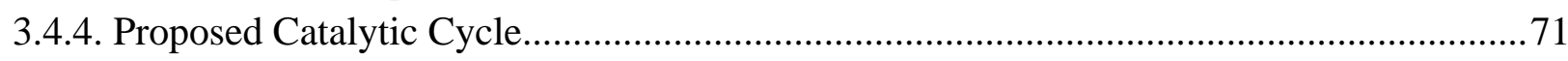

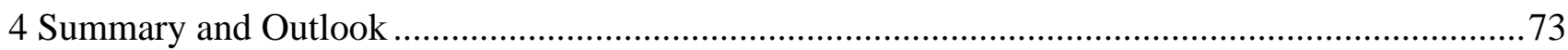

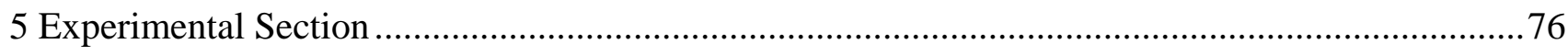

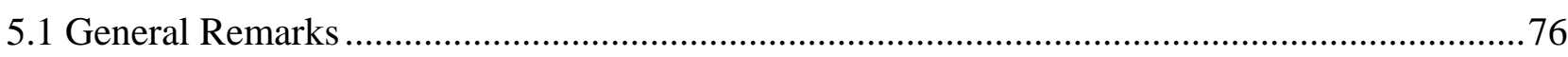

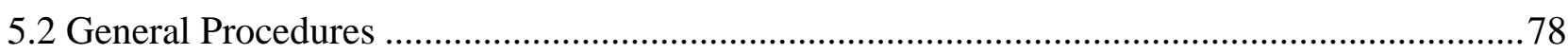

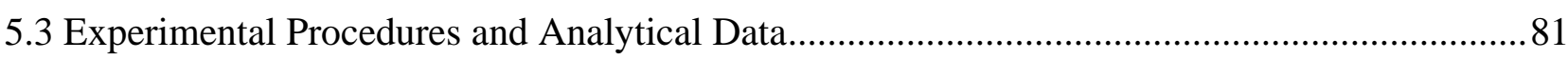

5.3.1 Ruthenium-Catalyzed Oxidative C-H Alkenylations of Arylacetamides........................81

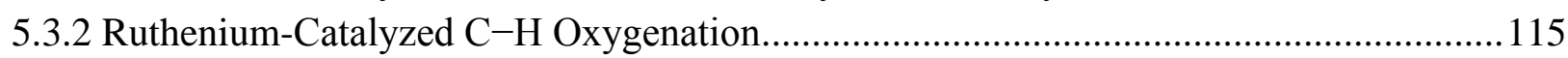

5.3.3 Low-Valent Cobalt-Catalyzed C-H Arylation............................................................ 124

5.3.4 Cobalt-Catalyzed C-H/C-C Functionalizations ..................................................... 142 
Reference

169

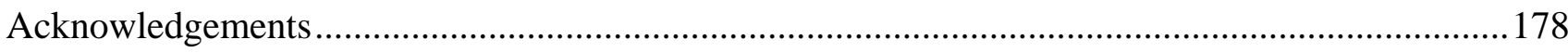

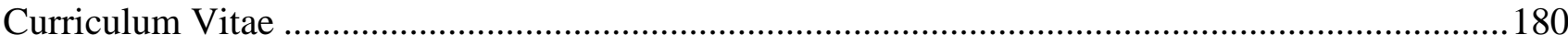


Abbreviations

\section{Abbreviations}

Ac

Ad

Alk

Aq.

$\mathrm{Ar}$

atm

ATR

BIES

$\mathrm{Bn}$

$\mathrm{Bu}$

cat

CMD

conv.

$\mathrm{Cp}$

$\mathrm{Cp} *$

$\mathrm{Cy}$

$\delta$

$\delta$

DCE

DCM

dd

DFT

DG

DMA

DMF

DMSO acetyl

adamantyl

alkyl

aqueous

aryl

atmospheric pressure

attenuated total reflectance

base-assisted internal electrophilic substitution

benzyl

butyl

catalytic

concerted metalation-deprotonation

conversion

cyclopentadienyl

1,2,3,4,5-pentamethylcyclopentadienyl

cyclohexyl

chemical shift

doublet

1,2-dichloroethane

dichloromethane

doublet of doublet

density functional theory

directing group

$\mathrm{N}, \mathrm{N}$-dimethylformamide

$N, N$-dimethylacetamide

Dimethylsulfoxide 
$\mathrm{dt}$

EDG

EI

equiv

ESI

Et

EWG

FG

g

GC-MS

GVL

h

Het

Hept

Hex

HPLC

HRMS

$\mathrm{Hz}$

$i$

IES

IR

$J$

KIE

L

$m$

$\mathrm{m}$

M doublet of triplet

electron-donating group

electron ionization

equivalents

electronspray ionization

ethyl

electron-withdrawing group

functional group

gram

gas chromatography-mass spectrometry

$\gamma$-valerolactone

hour

hetero(aryl)

heptyl

hexyl

high performance liquid chromatography

high resolution mass spectrometry

Hertz

iso

internal electrophilic substitution

infrared

coupling constant

kinetic isotope effect

ligand

meta

multiplet

metal 


\begin{tabular}{|c|c|}
\hline$[\mathrm{M}]^{+}$ & molecular ion peak \\
\hline $\mathrm{Me}$ & methyl \\
\hline Mes & 2,4,6-trimethylphenyl \\
\hline $\mathrm{Mg}$ & Milligram \\
\hline $\mathrm{MHz}$ & megahertz \\
\hline $\mathrm{mL}$ & milliliter \\
\hline mmol & millimol \\
\hline M.p. & melting point \\
\hline MS & mass spectrometry \\
\hline$m / z$ & mass-to-charge ratio \\
\hline NMP & $N$-methyl-2-pyrrolidinone \\
\hline NMR & nuclear magnetic resonance \\
\hline$o$ & ortho \\
\hline$P$ & para \\
\hline $\mathrm{P}$ & $\operatorname{PhI}(\mathrm{TFA})_{2}$ \\
\hline PEG & polyethylene glycol \\
\hline $\mathrm{Ph}$ & phenyl \\
\hline Piv & 2,2-dimethylpropanoyl \\
\hline ppm & parts per million \\
\hline $\mathrm{pKa}$ & logarithmic acid dissociation constant \\
\hline $\operatorname{Pr}$ & propyl \\
\hline py & pyridine \\
\hline AQ & aminoquinolin \\
\hline Q & Quartet \\
\hline ref. & reference \\
\hline RT & room temperature \\
\hline s & singlet \\
\hline
\end{tabular}


Abbreviations

sat.

$t$

$\mathrm{t}$

$\mathrm{T}$

$\mathrm{t}-\mathrm{Am}$

Tf

TFE

TFA

TFAA

THF

TM

TS

Ts

X saturated

tert

triplet

temperature

tert-Amyl

trifluoromethanesulfonyl

2,2,2,-trifluoroethanol

trifluoroacetic acid

Trifluoroacetic anhydride

tetrahydrofuran

transition metal

transition state

tosyl

(pseudo)halide 



\section{Introduction}

\subsection{Transition Metal-Catalyzed C-H Functionalizations}

Carbon-carbon $(\mathrm{C}-\mathrm{C})$ and carbon-heteroatom $(\mathrm{C}-\mathrm{X})$ bonds are the basis of organic molecules in medicinal agents, functional materials, and natural products. ${ }^{[1]}$ Therefore, many organic chemists have focused on the development of novel methods for the construction of these bonds. In the past few decades, transition metal-catalyzed transformations, such as cross-coupling reactions, became one of the most powerful and reliable tools for the formation of $\mathrm{C}-\mathrm{C}$ and $\mathrm{C}-\mathrm{X}$ bonds (Scheme 1). ${ }^{[2]}$ In particular, the importance of this class of reactions was recognized with the Nobel Prize for Chemistry in 2010, the Mizoroki-Heck reaction, ${ }^{[3]}$ the Negishi coupling, ${ }^{[4]}$ and the Suzuki-Miyaura coupling. ${ }^{[5]}$ Despite the indisputable advances, the major drawback of cross-coupling reactions is the necessity for pre-activation of both reactive components, which add costly chemical steps to the overall synthesis. Inspired by the need for green and sustainable chemistry, synthetic chemists hence seek more efficient ways to construct $\mathrm{C}-\mathrm{C}$ and $\mathrm{C}-\mathrm{X}$ bonds.

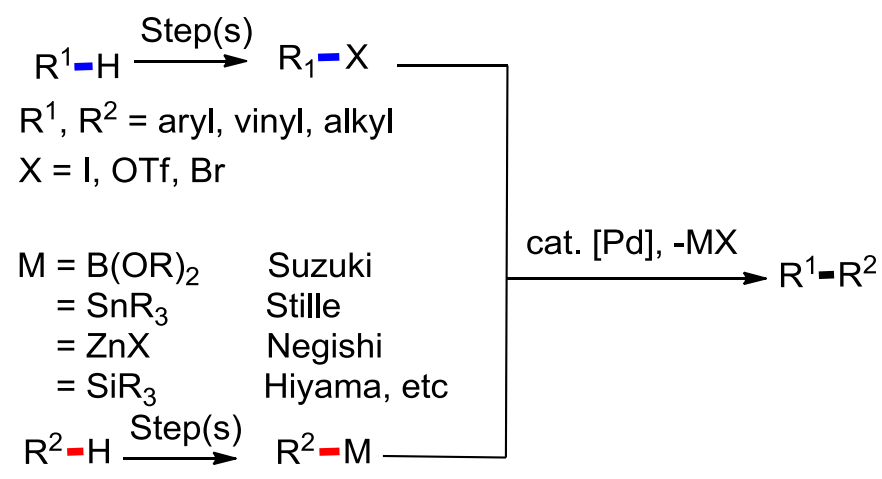

Scheme 1. Palladium-catalyzed cross-coupling reactions.

Recently, transition metal-catalyzed $\mathrm{C}-\mathrm{H}$ bond activation has emerged as an attractive alternative for $\mathrm{C}-\mathrm{C}$ and $\mathrm{C}-\mathrm{X}$ bond formation. This approach avoids the need of prefunctionalization of starting materials, and reduces or eliminates salt wastes, which result in high atom- and step-economy. Various transition metal catalysts such as palladium, ${ }^{[6]}$ ruthenium, ${ }^{[7]}$ rhodium, ${ }^{[8]}$ copper, ${ }^{[9]}$ iridium, ${ }^{[10]}$ manganese ${ }^{[11]}$ and others, ${ }^{[12]}$ have made a significant progress in enhancing the efficiency of $\mathrm{C}-\mathrm{H}$ bond transformation of heteroaromatic compounds. The direct $\mathrm{C}-\mathrm{H}$ bond functionalization of 
heterocycles can be arbitrarily classified into the following three general types (Scheme 2): (i) coupling of heteroarenes with electrophilic reactants, such as aryl-, alkyl-, alkenyl-, or alkynyl (pseudo)halides, ${ }^{[13]}$ (ii) reactions of heteroarenes with nucleophilic coupling partners, including aryl-, alkyl-, or alkenyl boronic acids, ${ }^{[14]}$ and (iii) cross-dehydrogentative couplings of heteroarenes with either another type of heteroarenes or hydrocarbons, including arenes, alkenes, alkynes, or alkanes. $^{[15]}$

(i)

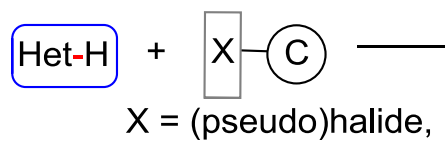

(ii)

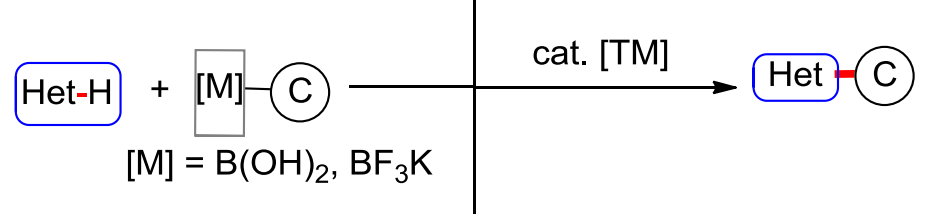

(ii)

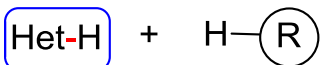

(C) = aryl, alkenyl, alkynyl, alkyl

Scheme 2. The general methods for $\mathrm{C}-\mathrm{C} / \mathrm{C}-\mathrm{Het}$ formation.

The challenges in transition metal-catalyzed $\mathrm{C}-\mathrm{H}$ activation chemistry are mostly the chemo- and site-selectivities. Site selectivity can be controlled by the close proximity of $\mathrm{C}-\mathrm{H}$ bonds to the reactive metal center. In the most cases, this is achieved by the introduction of directing group into the substrate core, which contains heteroatoms able to coordinate to metal center. The interaction of substrates and catalyst is then promoted through the coordination of heteroatoms to the transition metal catalysts (Scheme 3). ${ }^{[16]}$ Consequently, coordination of transition metals with directing groups, namely the chelation-assisted $\mathrm{C}-\mathrm{H}$ activation strategy, is usually considered as an essential step involved in these catalytic $\mathrm{C}-\mathrm{H}$ bond activation processes.

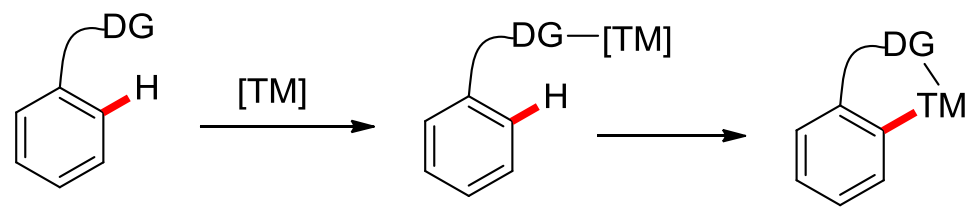

Scheme 3. Site-selective C-H activation by chelation-assistance. 
Various functional groups, including amide, ${ }^{[17]}$ anilide, ${ }^{[18]}$ imine,${ }^{[19]}$ heterocycles, ${ }^{[20]}$ as well as weakly coordinating functional group, like carboxylic acid, ${ }^{[21]}$ ester, ${ }^{[22]}$ ketone, ${ }^{[23]}$ and hydroxyl groups, ${ }^{[24]}$ have been employed as directing groups for catalytic $\mathrm{C}-\mathrm{H}$ bond activation (Figure 1).<smiles>[R]C(=O)N([R])CC</smiles>

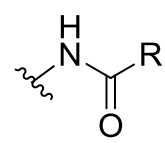<smiles>[R]C(=[V])N=[V]</smiles><smiles>CC(C)(C)c1ccccn1</smiles><smiles>Cn1cccn1</smiles><smiles>[13CH3]C(=O)O</smiles><smiles>[R]OC([14CH3])=O</smiles>

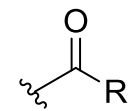<smiles>[14CH2]O</smiles>

Figure 1. Selected examples of important directing groups employed in $\mathrm{C}-\mathrm{H}$ activation reactions.

\subsection{Ruthenium-Catalyzed C-H Functionalizations}

In the past decades, the catalytic functionalization of $\mathrm{C}-\mathrm{H}$ bonds has emerged as a powerful tool for the production of pharmaceuticals and natural products and also it opened new routes for synthesis of materials and polymers. ${ }^{[25]}$ The regioselective direct transformation of $\mathrm{C}-\mathrm{H}$ bonds to $\mathrm{C}-\mathrm{C}$ bonds offers a unique opportunity to replace the classical catalytic cross-coupling reactions. ${ }^{[3,5 b, 26]}$ Tremendous progress has been made in transition metal-catalysed $\mathrm{C}-\mathrm{H}$ activation, most notably in the area of palladium and rhodium catalysis. ${ }^{[6 c, 8 c]}$ Futermore, inexpensive ruthenium complexes (Figure 2) also have been widely explored for efficient catalytic conversion of $\mathrm{C}-\mathrm{H}$ bonds. ${ }^{[7 c, 27]}$

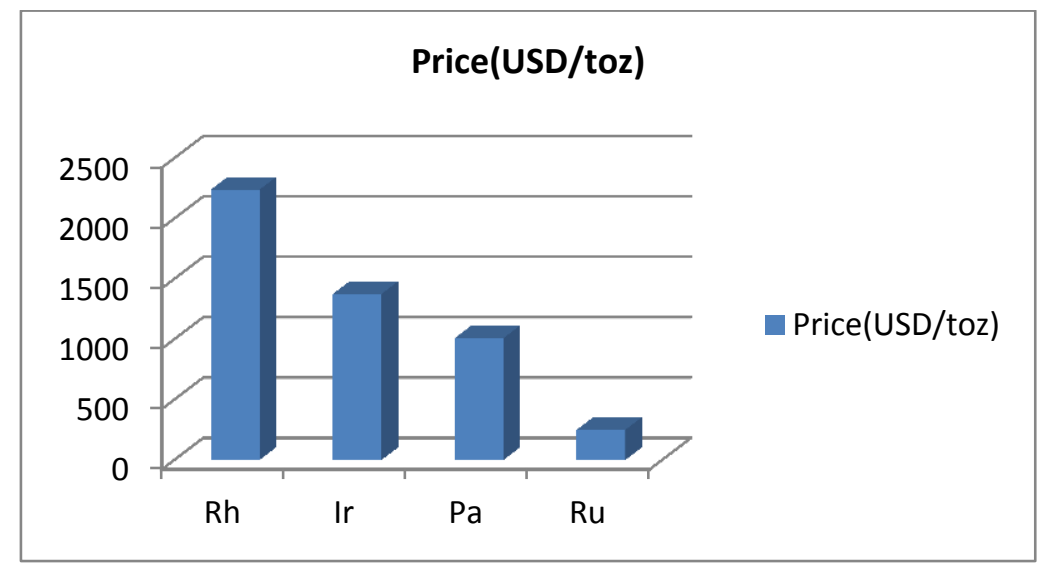

Figure 2. The prices of transition metals in 06.2018. 
For example, the inert $\mathrm{C}\left(\mathrm{sp}^{2}\right)-\mathrm{H}$ bonds have been successfully functionalized by inexpensive and active ruthenium $(0)$ catalyst $\left[\mathrm{RuH}_{2}(\mathrm{CO})\left(\mathrm{PCy}_{3}\right)_{2}\right] .{ }^{[28]}$ It was shown that an organometallic ruthenium complex can insert into $\mathrm{C}-\mathrm{H}$ bonds to generate a reactive $\mathrm{C}-\mathrm{Ru}-\mathrm{H}$ species via unsaturated substrate insertion processes. Versatile ruthenium(II) complexes have also been employed as the catalysts in $\mathrm{C}-\mathrm{H}$ activation transformations. The major contribution into this area have made by the Ackermann group, they focused on the application of ruthenium(II) complexes for $\mathrm{C}-\mathrm{H}$ bond activations, ${ }^{[29]}$ following the pioneering but not robust work of $\mathrm{Oi}$ and Inoune in 2001. ${ }^{[30]}$ The ruthenium(II)-catalyzed $\mathrm{C}-\mathrm{H}$ activation procceeds via a chelation-assisted $\mathrm{C}-\mathrm{H}$ metalation to deliver cyclometalated ruthenium(II) complex 1. ${ }^{[31]}$ Then, further activation steps for $\mathrm{C}-\mathrm{H}$ activation via oxidative addition of organohalides or insertion of unsaturated substrates delivered the products 2 or 3 respectively (Scheme 4). ${ }^{[27 a, 32]}$

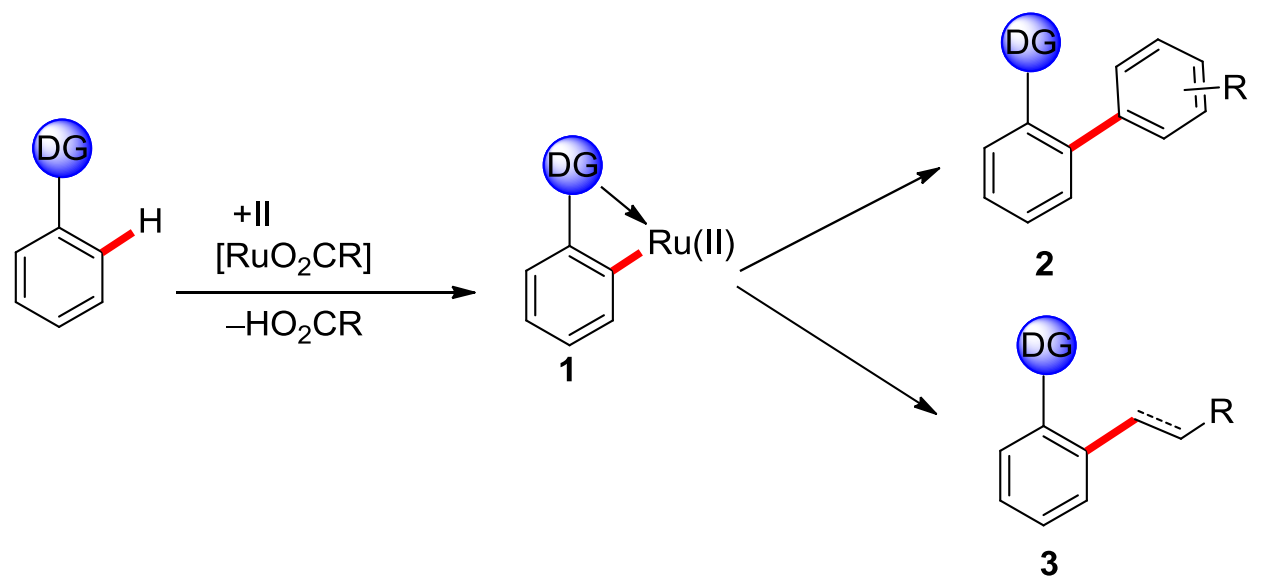

Scheme 4. Ruthenium-catalyzed $\mathrm{C}-\mathrm{H}$ activation.

\subsubsection{Ruthenium Catalyzed C-H Alkenylation}

Styrene derivatives are useful intermediates in synthetic organic chemistry. ${ }^{[33]}$ They can be obtained by Mizoroki-Heck reaction between arylhalides and alkenes in the presence of a palladium catalyst and base. ${ }^{[15 a]}$ In the most atom- and step-economical fashion, synthesis of alkenylarenes can be achieved by a $\mathrm{C}-\mathrm{H}$ activation reaction.

Based on an early report by Fujiwara and Moritani, ${ }^{[34]}$ a wealth of palladium- and rhodium-catalyzed oxidative alkenylations were developed. Less expensive ruthenium complexes were also explored in oxidative $\mathrm{C}-\mathrm{H}$ alkenylations reactions. ${ }^{[35]}$ 
In 2001, an early example of oxidative alkenylaton of an alkene $\mathbf{5}$ with aromatic $\mathrm{C}-\mathrm{H}$ bond was reported by Milstein and co-workers using $\mathrm{RuCl}_{3} \cdot 3 \mathrm{H}_{2} \mathrm{O},\left[\mathrm{Ru}(\mathrm{CO})_{3} \mathrm{Cl}_{2}\right]_{2}, \quad\left[\left(\eta^{6}-\mathrm{C}_{6} \mathrm{H}_{6}\right) \mathrm{RuCl}_{2}\right]_{2}$ or $\mathrm{Ru}(\mathrm{NO}) \mathrm{Cl}_{3} \cdot 5 \mathrm{H}_{2} \mathrm{O}$ catalyst complexes under an atmosphere of $\mathrm{CO}$ and $\mathrm{O}_{2}$ at $180{ }^{\circ} \mathrm{C}$ (Scheme 5). ${ }^{[36]}$ low yield of up to $40 \%$ of alkenylated arenes 6 were obtained. The optimizied results show that $\mathrm{O}_{2}$ or alkene can serve as oxidant and ruthenium(II) and ruthenium(III) had the same catalytic activity, whereas the ruthenium(0) precursor $\mathrm{Ru}_{3}(\mathrm{CO})_{12}$ was much less active. Directing groups were not required under the reaction conditions, however only poor site-selectivities were obtained.

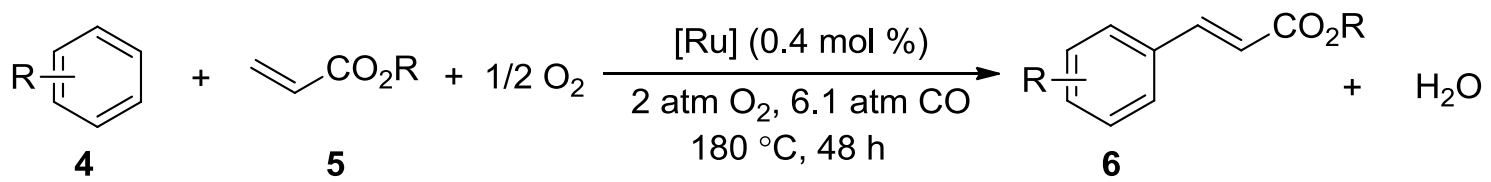<smiles>COC(=O)/C=C/c1ccccc1C</smiles>

6a: $44 \%(p: m=1: 1.6)$<smiles>C=C(C)c1ccccc1C</smiles>

6b: $4.4 \%(p: m=1: 1.6)$

Scheme 5. Ruthenium-catalyzed C-H alkenylation of arenes 4 with olefins 5.

Later, Brown and co-workers reported the oxidative Heck reaction of arene boronic acids 7 with acrylate 5a catalyzed by $\left[\mathrm{RuCl}_{2}(p \text {-cymene })_{2}\right]_{2}$ in the presence of $\mathrm{Cu}(\mathrm{OAc})_{2}$ as the oxidant (Scheme 6). ${ }^{[37]}$ In contrast to palladium catalyst system, in this reaction halides on the arenes 7 were tolerated. 


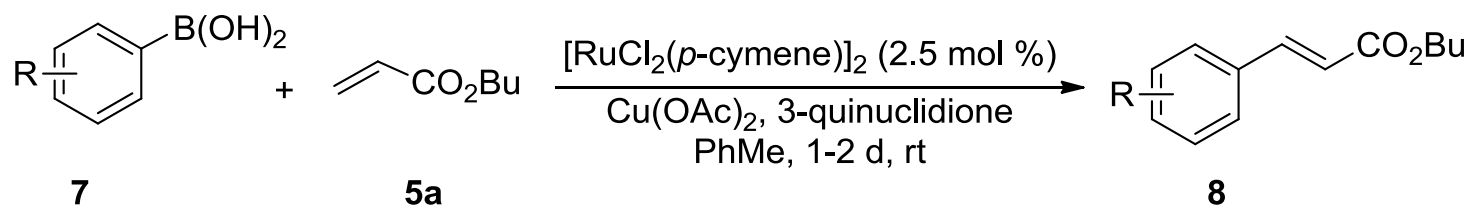<smiles>O=C(OCC=Cc1ccccc1)OCc1ccccc1</smiles>

3-Cl (8a): $77 \%$

4-Cl (8b): $93 \%$<smiles>CCCOC(=O)C=Cc1ccc(Br)cc1</smiles>

$3-\operatorname{Br}(8 c): 63 \%$ 4-Br (8d): $96 \%$<smiles>CCCOC(=O)C=Cc1ccccc1</smiles>

3-I (8e): $76 \%$ 4-I (8f): $77 \%$

Scheme 6. Ruthenium-catalyzed oxidation Heck reaction.

Later, the cross-coupling of $\mathrm{C}\left(\mathrm{Sp}^{2}\right)-\mathrm{H}$ bonds between an alkene and an arene was achieved by Yi and co-workers using cationic ruthenium hydride complex $\left[\left(\eta^{6}-\mathrm{C}_{6} \mathrm{H}_{6}\right)-\left(\mathrm{PCy}_{3}\right)(\mathrm{CO}) \mathrm{RuH}\right]^{+} \mathrm{BF}_{4}^{-}$as the catalyst precursor. ${ }^{[38]}$ The cationic ruthenium hydride complex was found to be a highly site-selective catalyst for the oxidative $\mathrm{C}-\mathrm{H}$ bond alkenylation of aryl-substituted amides $\mathbf{9}$ and unactivated alkenes 10 to give $o$-alkenylamide products 11 (Scheme 7a). In addition, kinetic experiments were performed to gain mechanistic insights into the coupling reaction. To examine the H/D exchange pattern on the amide substrate, the treatment of $\mathrm{C}_{6} \mathrm{D}_{5} \mathrm{C}(\mathrm{O}) \mathrm{NEt}_{2}\left([\mathrm{D}]_{5}-\mathbf{9 a}\right)$ and cyclopentene (10a) in the presence of the catalyst was performed. The result indicated a reversible arene $\mathrm{C}-\mathrm{H}$ activation step (Scheme 7b). In support of this notion, a negligible isotope effect of $k_{\mathrm{H}} / k_{\mathrm{D}}=1.1$ was found for the competition reaction between $\mathrm{C}_{6} \mathrm{H}_{5} \mathrm{C}(\mathrm{O}) \mathrm{NEt}_{2}$ (9a) and $\mathrm{C}_{6} \mathrm{D}_{5} \mathrm{C}(\mathrm{O}) \mathrm{NEt}_{2} \quad\left([\mathrm{D}]_{5}-\mathbf{9 a}\right)$ with cyclopentene (10a). Further detailed kinetic studies supported a mechanism involving a rapid vinyl $\mathrm{C}-\mathrm{H}$ activation followed by a rate-limiting $\mathrm{C}-\mathrm{C}$ bond forming reductive elimination. In these reactions, no external oxidant was added, the alkene as well as the newly formed alkenylated product severed here as hydrogen scavenger. Therefore the alkenylated product $\mathbf{1 1}$ was formed along with hydrogenated benzamides $\mathbf{1 2}$ as an insepeable mixture. 
a)<smiles>[R][R]1ccc(C2CCC([Y20])C2)c(C(=O)N([R])[R])c1</smiles>

b)

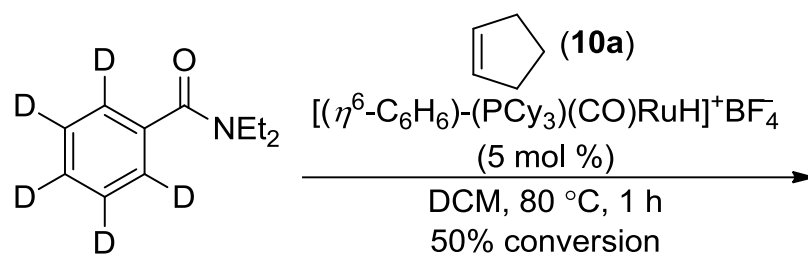

$[D]_{5}-9 a$<smiles>[2H]c1c([2H])c(C2=CCCC2)c(C(=O)NCC)c([Sb](=O)(=O)O)c1[2H]</smiles>

$(90: 10)$<smiles></smiles>

$[\mathrm{D}]_{n}-12 \mathbf{a a}$

$[\mathrm{D}]_{n}-9 \mathbf{a}$

Scheme 7. Ruthenium-catalyzed oxidative alkenylations of benzamides 9.

In 2011, the Ackermann group showed that the weakly-coordinating carboxylic group could direct the alkenylation with ruthenium(II) catalyst at the ortho-position of benzoic acid derivatives 13 with acrylates 5 or acrylonitrile 14 with 2 equivalent of oxidant $\mathrm{Cu}(\mathrm{OAc})_{2} \cdot \mathrm{H}_{2} \mathrm{O}$ (Scheme 8). ${ }^{[39]}$ This reaction occurred efficiently in environmentally benign water, in contrast to related palladium- or rhodium-catalyzed reactions, ${ }^{[40]}$ which were thus far could have been performed only in organic solvents. The alkenylated product underwent oxo-Michael addition, thus leading to a variety of lactones 15. The catalytic system tolerated valuable electrophilic functional groups, such as fluoro or bromo substituents, and even sterically hindered ortho-substituted acids 13a-13f were also accepted. 


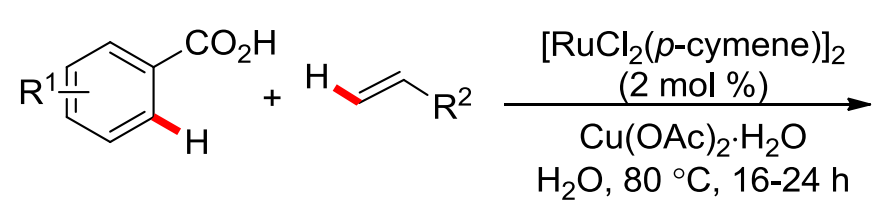

13

5 or 14<smiles>[R]CC1OC(=O)c2c[R1]#ccc21</smiles>

15<smiles>CCOC(=O)CC1OC(=O)c2c(OC)cc(OC)cc21</smiles>

15aa: $90 \%$<smiles>N#CCC1OC(=O)c2c1cccc2C(F)(F)F</smiles>

15db: $71 \%$

15ba: $66 \%$<smiles>CCOC(=O)CC1OC(=O)c2c(C)cc(Br)cc21</smiles>

15ec: $67 \%$<smiles>N#CCC1OC(=O)c2c(F)cccc21</smiles>

15cb: $76 \%$<smiles>Cc1cc(C)c2c(c1)C(C(C)C#N)OC2=O</smiles>

15fd: $80 \%($ d.r. $=2.6: 1)$

Scheme 8. Ruthenium-catalyzed oxidative alkenylation of benzoic acid in water.

Furthermore, the Ackermann group expanded the ruthenium(II)-catalyzed oxidative alkenylations process to other valuable substrates, such as anilides 16 and amides 9 (Scheme 9a). The high selectivity monoalkenylated products 18 were achieved using the $\left[\mathrm{RuCl}_{2}(p \text {-cymene) }]_{2} \mathbf{1 7}\right.$ catalyst with the non-coordinating salt $\mathrm{KPF}_{6}(20 \mathrm{~mol} \%)$ in the presence of $\mathrm{Cu}(\mathrm{OAc})_{2} \cdot \mathrm{H}_{2} \mathrm{O}{ }^{[41]}$ The intermolecular competition experiments revealed electron-rich anilides $\mathbf{1 6 b}$ to be preferentially functionalized (Scheme 9b). However, when using $N$-benzoyl anilines 19 as the substrates, the alkenylation reaction peformed only at the ortho $\mathrm{C}-\mathrm{H}$ bond of the aromatic ring linked to the amide carbonyl showing the preferential activation/alkenylation by the $-\mathrm{C}(\mathrm{O}) \mathrm{NHPh}$ than the $-\mathrm{NHC}(\mathrm{O}) \mathrm{Ph}$ group (Scheme 9c). 
a)<smiles>[R]OCC=Cc1ccc[R1]([H])c1[O-]</smiles><smiles>CCOC(=O)/C=C/c1ccccc1NC(=O)C(C)(C)C</smiles><smiles>CCOC(=O)/C=C/c1ccc(Cl)cc1NC(C)=O</smiles><smiles>CCOC(=O)C=Cc1cccc(OC)c1C(=O)N[Na]</smiles><smiles>CCOC(=O)/C=C/c1ccc(C(F)(F)F)cc1C(=O)N[Na]</smiles>

18a: $62 \%$

18b: $66 \%$

18c: $65 \%$

18d: $51 \%$

b)<smiles>CC(=O)Nc1ccc(F)cc1[18F]</smiles>

$16 a$<smiles>CC(=O)Nc1ccccc1</smiles>

$16 b$

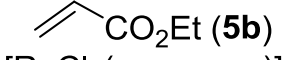

$\left[\mathrm{RuCl}_{2}(p \text {-cymene })\right]_{2}$ $(5.0 \mathrm{~mol} \%)$

$\underset{\mathrm{Cu}(\mathrm{OAc})_{2} \cdot \mathrm{H}_{2} \mathrm{O}}{\mathrm{KPF}_{6}(20 \mathrm{~mol} \%)}$

$\mathrm{H}_{2} \mathrm{O}, 120^{\circ} \mathrm{C}, 20 \mathrm{~h}$

$42 \%$ conv.

$18 a b: 18 b b=1.0: 2.5$<smiles>CCOC(=O)/C=C/c1cc(F)ccc1NC(C)=O</smiles><smiles>CCOC(=O)/C=C/c1ccccc1NC(C)=O</smiles>

$18 \mathrm{bb}$

$18 a b$

c)<smiles>[R]c1ccc(NC(=O)c2ccccc2)cc1</smiles>

19

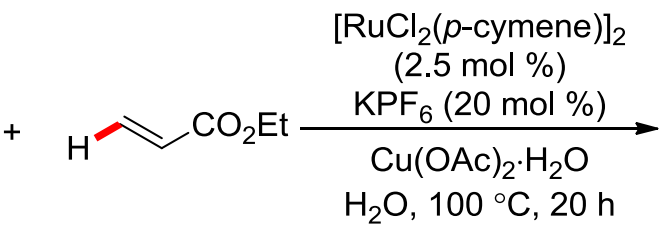

$5 b$<smiles>[R]OC=Cc1ccccc1C(=O)Nc1ccc([R])cc1</smiles>

$\mathrm{R}=\mathrm{H}(\mathbf{2 0 a b}), 46 \%$

$R=F(20 b b), 47 \%$

Scheme 9. Ruthenium-catalyzed $\mathrm{C}-\mathrm{H}$ alkenylation of anilides and amides. 
In contrast to the chelation-assisted alkenylations of benzamides, ruthenium-catalyzed oxidative functionalizations of weakly coordinating esters $\mathbf{2 1},{ }^{[42]}$ aldehydes $\mathbf{2 3}^{[43]}$ have also been reported by the research groups of Ackermann and Jeganmohan. By reacting the catalyst $\left[\mathrm{RuCl}_{2}(p \text {-cymene })\right]_{2}$ with $\mathrm{AgSbF}_{6}$ to abstract the chlorides from the ruthenium(II) complex, in the presence of $\mathrm{Cu}(\mathrm{OAc})_{2} \cdot \mathrm{H}_{2} \mathrm{O}$ as an acetate provider and oxidant, they succeeded here towards the alkenylation process (Scheme 10).

a) Ackermann, 2012<smiles>[R]OC(=O)c1cc#[R]cc1</smiles>

21

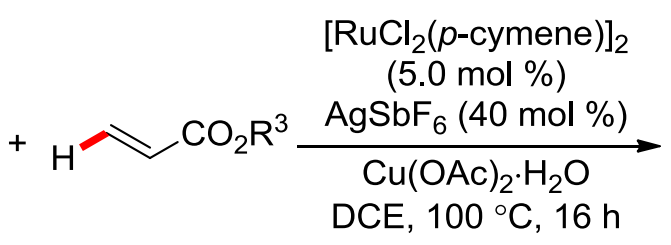

5<smiles>[R]OC(=O)C=Cc1c[R]([R])ccc1C(=O)O[R]</smiles>

22

b) Jeganmohan, 2012<smiles>O=Cc1cc#[R]cc1</smiles>

23<smiles>[R]OC(=O)C=[CH+]</smiles>

5

$$
\begin{gathered}
{\left[\begin{array}{c}
\left.\operatorname{RuCl}_{2}(p \text {-cymene })\right]_{2} \\
(3.0 \mathrm{~mol} \%)
\end{array}\right.} \\
\underset{\mathrm{AgSbF}}{\mathrm{AgS}(20 \mathrm{~mol} \%)} \\
\stackrel{\mathrm{Cu}(\mathrm{OAc})_{2} \cdot \mathrm{H}_{2} \mathrm{O}}{\longrightarrow} \\
\mathrm{DCE}, 100{ }^{\circ} \mathrm{C}, 16 \mathrm{~h}
\end{gathered}
$$<smiles>[R]OCC=CC1=C[Z10]([R])C=CC=C1C=O</smiles>

24

Scheme 10. Ruthenium(II)-catalyzed C-H alkenylation with weakly coordinating esters 21 and aldehydes $\mathbf{2 3}$ as directing groups.

Based on H/D-exchange experiments of ruthenium(II)-catalyzed $\mathrm{C}-\mathrm{H}$ alkenylation, the Ackermann group proposed the catalytic cycle to involve an initial reversible acetate-assisted cycloruthenation to form complex 26 (Scheme 11). Subsequent migratory insertion of alkene $\mathbf{5}$ and $\beta$-hydride elimination furnish desired product 22 , while reductive elimination and reoxidation by $\mathrm{Cu}(\mathrm{OAc})_{2}$ regenerate the catalytically active cationic species $\mathbf{2 5}$. 


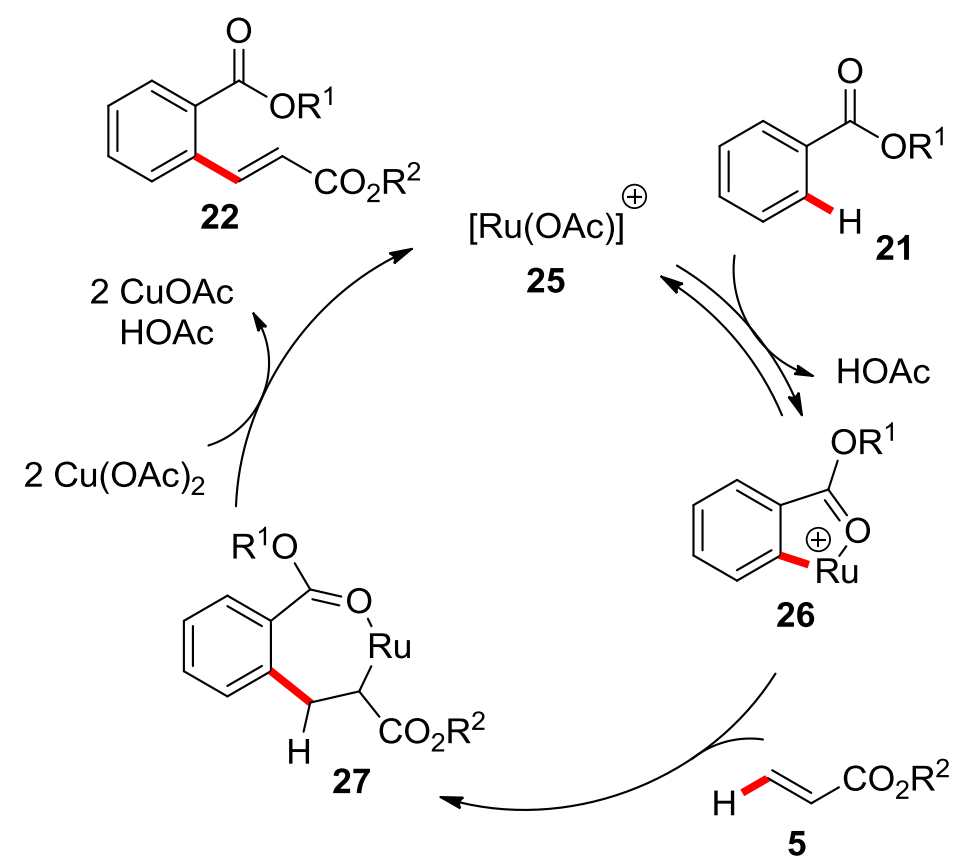

Scheme 11. Proposed catalytic cycle of ruthenium(II)-catalyzed C-H alkenylation of arenes.

The hydroxyl group of phenols does not direct ruthenium(II)-catalyzed C-H bond activation, but it's derivatives such as carbamates ${ }^{[44]]}$ and the strongly coordinating 2-pyridyl group ${ }^{[45]}$ have been shown to direct the ortho-selective $\mathrm{C}-\mathrm{H}$ cleavage to obtain the alkenylated products 28 . In 2012, the Ackermann group showed that carbamate derivatives of phenols $\mathbf{2 9}$ could undergo ortho-alkenylation with acrylates $\mathbf{5 b}$ in the presence of catalytic amount of $\left[\mathrm{RuCl}_{2}(p \text {-cymene })\right]_{2}$ and $\mathrm{AgSbF}_{6}$ with $\mathrm{Cu}(\mathrm{OAc})_{2}$ as oxidant in DME. The reaction was compatibles with a wide range of functional groups, including alkyl fluoro, chloro or bromo (Scheme 12). ${ }^{[44]}$ The carbamate directing group was easily removed to provide ortho-alkenylated phenol under basic reaction condition. 


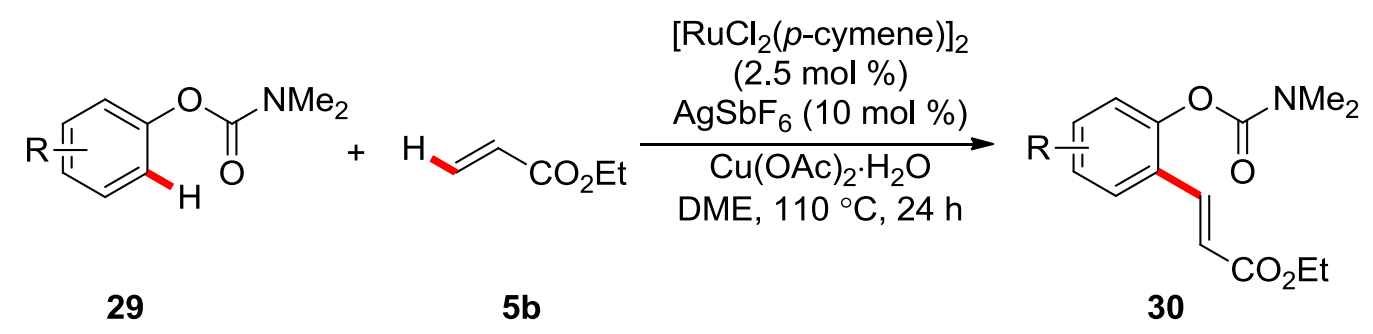<smiles>CCOC(=O)C=Cc1cccc(-c2ccccc2)c1OC(C)=O</smiles>

30a: $77 \%$<smiles>CCOC(=O)/C=C/c1cccc(C(F)(F)F)c1OC(=O)N(C)C</smiles>

30b: $65 \%$<smiles>CCOC(=O)/C=C/c1cccc(Cl)c1OC(=O)N(C)C</smiles>

30c: $51 \%$<smiles>CCOC(=O)/C=C/C=C/c1cc(Br)ccc1OC(=O)N(C)C(=O)Oc1ccc(C)cc1/C=C/C(=O)OCC</smiles>

30e: $56 \%$

30f: $60 \%$

30g: $61 \%$

Scheme 12. Oxidative C-H alkenylation of aryl carbamates 29.

Oxidative alkenylations of arenes with heterocyclic directing groups were also achieved in recent years. Dixneuf and co-workers reported on the synthesis of ortho-alkenylated $N$-arylpyrazoles 33 via ruthenium-catalyzed oxidative $\mathrm{C}-\mathrm{H}$ alkenylation of $N$-phenylpyrazole $31 \mathrm{a}$ using $\left[\mathrm{Ru}(\mathrm{OAc})_{2}(p\right.$-cymene) $]$ as the catalyst in HOAc at $100{ }^{\circ} \mathrm{C}$ (Scheme $\left.13 \mathrm{a}\right){ }^{[46]}$ For this reaction, in many cases the alkenylated products 33 were obtained with by-product 33' generated through dehydrogenative homocoupling. Later, Miura and Satoh reported the direct alkenylation of 1-phenylpyrazoles 31 with alkenes 32 using $\left[\mathrm{RuCl}_{2}(p \text {-cymene })\right]_{2}$ instead of $\left[\mathrm{Ru}(\mathrm{OAc})_{2}(p\right.$-cymene $\left.)\right]$ as catlyst in the presence of a copper (II) oxidant (Scheme 13b). ${ }^{[47]}$ The reaction was shown to tolerate various substituents on the arene ring, such as chloro, ester and nitrile groups. ${ }^{[48]}$ Here the formation of mixtures of mono- and bisalkenylated product (33 and 34) was observed. Under the same reaction conditions, a low yield was obtained for the phenylbenzothiazole $\mathbf{3 5}$ with acrylate $\mathbf{5}$. 
The $\mathrm{C}-\mathrm{H}$ alkenylation efficiency was considerably improved by the addition of $\mathrm{AgSbF}_{6}$ as the cocatalyst (Scheme13b).

a) Dixneuf

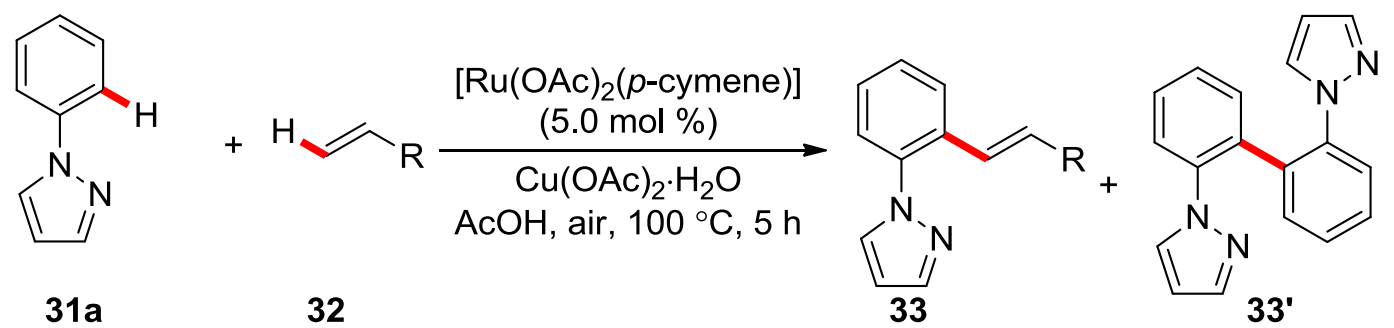

b) Miura<smiles>[R1]1=[R1]=CN=C1</smiles>

31<smiles>[R]C=C[NH2+]c1nc2ccccc2[nH]1</smiles>

35 32<smiles>[R]C=Cc1cccc(/C=C/[R])c1N1[R1]([R1])C=NN1/C=C/[R]</smiles>

$\left[\mathrm{RuCl}_{2}(p \text {-cymene })\right]_{2}$ $(5.0 \mathrm{~mol} \%)$ $\underset{\mathrm{Cu}(\mathrm{OAc})_{2} \cdot \mathrm{H}_{2} \mathrm{O}}{\mathrm{AgSbF}_{6}(20 \mathrm{~mol} \%)}$ $t-\mathrm{AmOH}, 100^{\circ} \mathrm{C}, 4 \mathrm{~h}$<smiles></smiles>

36

Scheme 13. Ruthenium-catalyzed C-H alkenylation.

Futhermore, in 2015, the Ackermann group reported the $\mathrm{C}-\mathrm{H}$ alkenylation of aromatic compounds with alkenes assisted by the 1,2,3-triazole group (Scheme 14). ${ }^{[49]}$ Under the optimal reaction conditions, the authors showed that various acrylates $\mathbf{5}$ and functional groups substituted aromatic rings 37 were tolerated. Particularly, a very good site-slectivity at a less hindered side of aromatics for the meta $\mathrm{Me}$ and $\mathrm{CF}_{3}$ substituted aromatics was observed. It is worth to note that heteroarenes 37c can be succesfully converted to indol derivative $38 \mathbf{c}$. 


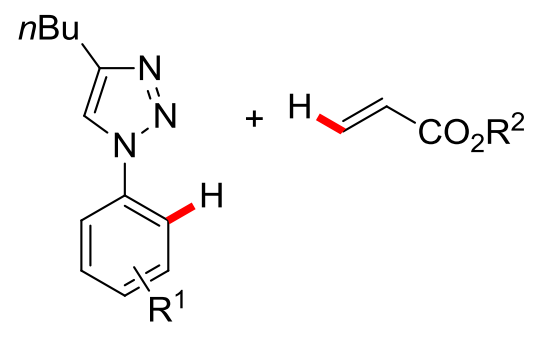

37

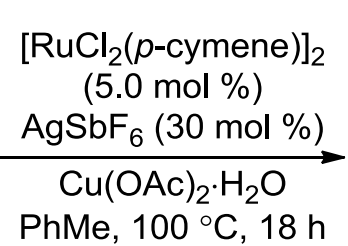

5<smiles>[R]OCC=Cc1ccccc1-n1cc(CCC)nn1</smiles>

38<smiles>CCCCc1cn(-c2cc(C)ccc2/C=C/C(=O)OCC)nn1</smiles>

38a: $65 \%$<smiles>CCCCc1cn(-c2cc(C(F)(F)F)ccc2/C=C/C(=O)OCC)nn1</smiles>

$38 b: 62 \%$<smiles>CCCCc1cn(-c2c(/C=C/C(=O)OCC)n(C)c3ccccc23)nn1</smiles>

38c: $50 \%$

Scheme 14. Ruthenium-catalyzed alkenylation of triazole derivatives 37.

Subsequently, the Ackermann group reported the efficient oxidative $\mathrm{C}-\mathrm{H}$ alkenylation of sulfonic acid, sulfonyl chlorides, and sulfonamides (39 and 41) with ample substrate scope. For the alkenylation of sulfonic acids, not only acrylates, but also vinyl sulfones, nitriles, phosphonates and ketones proved to be viable substrates. For the reaction of sulfonamides $\mathbf{4 1}$, the alkenylation was followed by intramolecular $a z a$-Michael reaction leading to cyclization into sultams $\mathbf{4 2}$ in good yields when increasing the temperature to $150{ }^{\circ} \mathrm{C}$ (Scheme 15). ${ }^{[50]}$ 
a)<smiles>[R][R5]Sc1cc[R1]cc1</smiles>

39<smiles>[R]C=C</smiles>

32
$\left[\mathrm{RuCl}_{2}(p \text {-cymene })\right]_{2}$

$(5.0 \mathrm{~mol} \%)$

$\underset{\mathrm{Cu}(\mathrm{OAc})_{2} \cdot \mathrm{H}_{2} \mathrm{O}}{\stackrel{\mathrm{AgSbF}_{6}(20 \mathrm{~mol} \%)}{\longrightarrow}}$

DMA, $120^{\circ} \mathrm{C}, 16 \mathrm{~h}$<smiles>[R]OC=Cc1cc[R1]#cc1S(=O)O[R4]</smiles>

40

$\mathrm{R}^{2}=\mathrm{H}, \mathrm{Cl}$

$\mathrm{R}^{3}=\mathrm{CO}_{2} \mathrm{R}^{4}, \mathrm{SO}_{2} \mathrm{Ph}, \mathrm{CN}, \mathrm{COMe}, \mathrm{PO}(\mathrm{OEt})_{2}$

$\mathrm{R}^{4}=$ Alk

b)

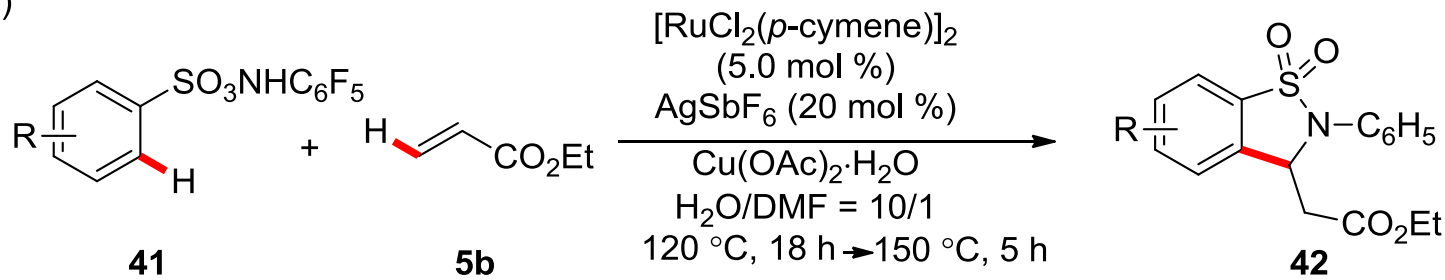

Scheme 15. Ruthenium-catalyzed $\mathrm{C}-\mathrm{H}$ alkenylation of sulfonic acid, sulfonyl chlorides, and sulfonamides 39.

Recently, the direct alkenylation of $\alpha, \alpha$-disubstituted benzylamines catalyzed by $\left[\mathrm{RhCp}^{*} \mathrm{Cl}_{2}\right]_{2}$ or low-cost $\left[\mathrm{RuCl}_{2}(p \text {-cymene })\right]_{2}$ in the presence of $\mathrm{Cu}(\mathrm{OAc})_{2}$ as oxidant was reported by Miura and co-workers. ${ }^{[51]}$ This was the first example of ruthenium(II)-catalysed $\mathrm{C}-\mathrm{H}$ bond functionalisation directed by a free $\mathrm{NH}_{2}$ group. When treating the $\alpha, \alpha$-disubstituted benzylamines $\mathbf{4 3}$ with alkenes 5 in the presence of $\left[\mathrm{RuCl}_{2}(p \text {-cymene })\right]_{2}$ and $\mathrm{Cu}(\mathrm{OAc})_{2}$ in dioxane at room temperature, the cyclization product $\mathbf{4 4}$ was formed in good yield (Scheme 16).<smiles>[R]C([R])(N)C1=CC=[R1]#CC=C1</smiles>

43
$\left[\mathrm{RuCl}_{2}(p \text {-cymene })\right]_{2}$ $(5.0 \mathrm{~mol} \%)$ $\mathrm{AgSbF}_{6}(20 \mathrm{~mol} \%)$

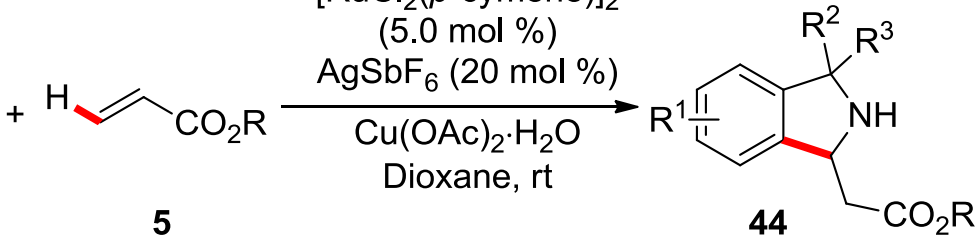

Scheme 16. Ruthenium-catalyzed alkenylation of $\alpha, \alpha$-disubstituted benzylamines 43 . 
The mechanism was suggested to involve the initial formation of a Ruthenium(II)-OAc species leading to form a five-membered metallacycle intermediate 46, then alkene insertion into aryl-metal bond to form 47 (Scheme 17). ${ }^{[51]}$ Subsequently, the $\beta$-hydrid elimination and the intramolecular Michael addition occur.

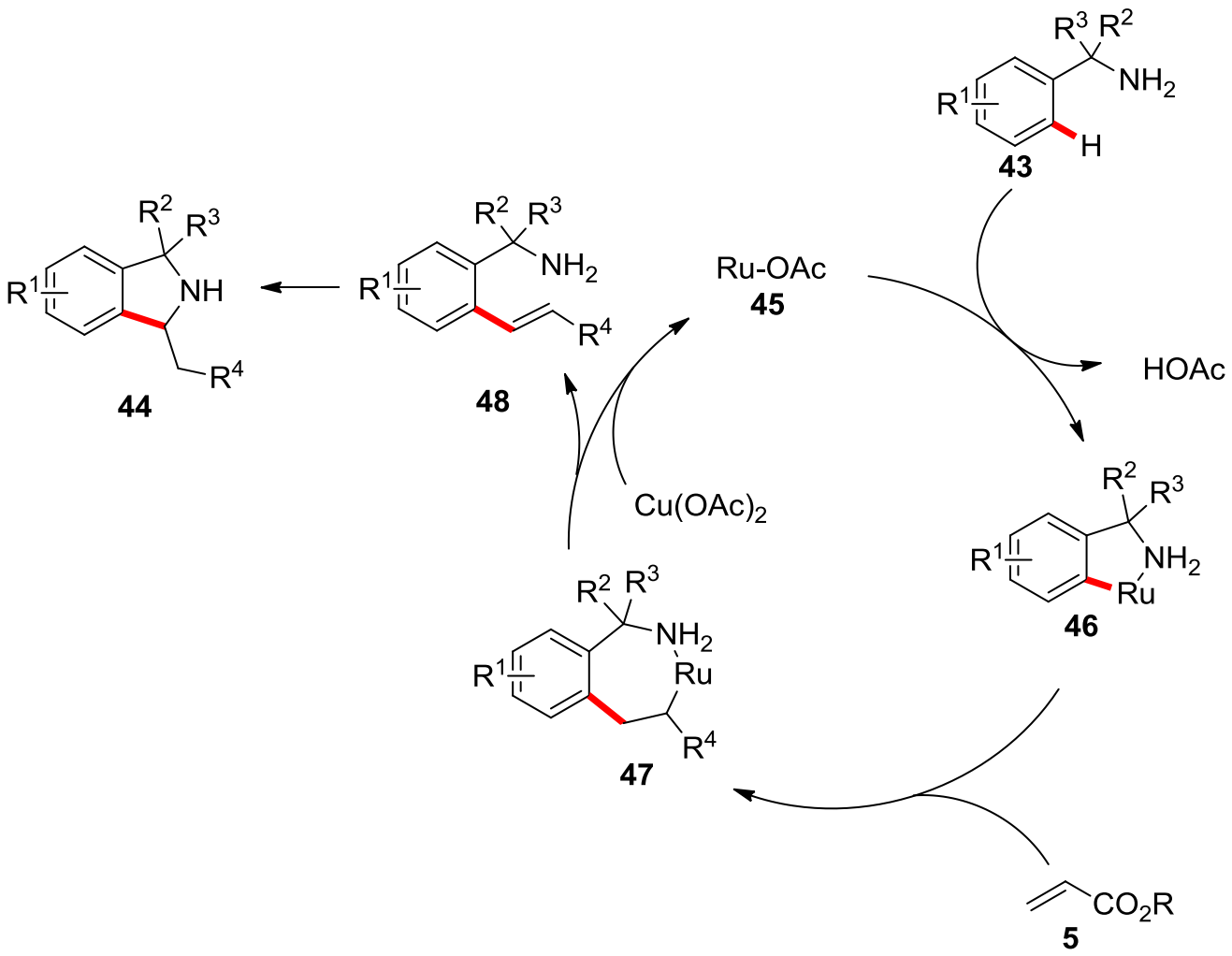

Scheme 17. A plausible pathway for the ortho-alkenylation of $\alpha, \alpha$-disubstituted benzylamines $\mathbf{4 3}$.

\subsubsection{Ruthenium-Catalyzed Hydroarylation}

Alkene derivatives are present various natural products, drug molecules and organic materials. They are also widely used in organic transformations. Based on the presented above transformation, alkene derivatives can be prepared by metal-catalyzed chelation-assisted oxidative alkenylation at the $\mathrm{C}-\mathrm{H}$ bond of arenes (Scheme 18a). ${ }^{[35]}$ Another efficient way to synthesize alkene derivatives is represented by metal-catalyzed hydroarylation of alkynes (Scheme $18 \mathrm{~b}) .^{[52]}$ 
a)

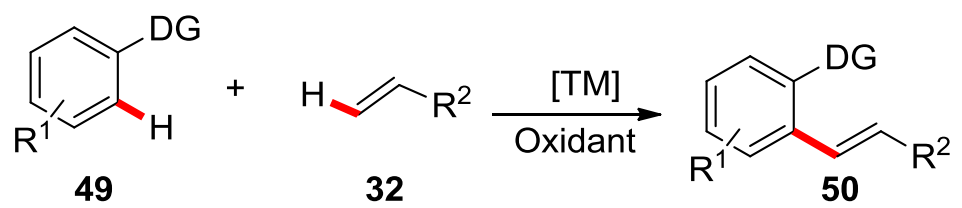

$\mathrm{TM}=\mathrm{Pd}, \mathrm{Rh}, \mathrm{Ru}, \mathrm{Co}, \ldots$

b)

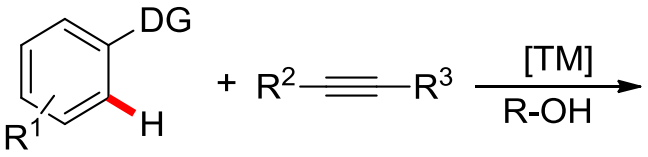

49

51<smiles>[R]C=C([R9])c1c[R]([R])ccc1[18OH]</smiles>

$\mathrm{TM}=\mathrm{Pd}, \mathrm{Rh}, \mathrm{Au}, \mathrm{Pt}, \mathrm{Ru}, \mathrm{Co}, \mathrm{Ni}, \ldots$

Scheme 18. Synthesis of alkene derivatives by $\mathrm{C}-\mathrm{H}$ activation.

As early as 1986, Lewis and Smith demonstrated ortho-metalation of aryl phosphites under Ru-catalyzed conditions. ${ }^{[53]}$ By catalytically generating the P-based directing group, they developed a hydroarylation approach to ortho-alkylated phenols. Subsequently, the Murai group reported a ruthenium-catalyzed chelation-assisted ortho-alkylation of aromatic ketones with alkenes via $\mathrm{C}-\mathrm{H}$ bond activation in the presence of $\mathrm{RuH}_{2}(\mathrm{CO})\left(\mathrm{PPh}_{3}\right)_{3}$ 53. ${ }^{[54]}$ Later, under the similar reaction conditions, the Murai group demonstrated that alkynes can successfully insert to aromatic ketones via chelation-assisted ortho $\mathrm{C}-\mathrm{H}$ cleavage (Scheme 19). When heating the mixure of ketone 54, internal alkyne 51 and $\mathrm{RuH}_{2}(\mathrm{CO})\left(\mathrm{PPh}_{3}\right)_{3}$ in toluene under $135{ }^{\circ} \mathrm{C}$, trisubstituted alkene 55 was achieved after 1-2 days. It is noteworthy that heteroaromatic ketons $\mathbf{5 6}$ were also tolerated. ${ }^{[55]}$ 
a) Hydroarylation of ketone<smiles>O=C1CCc2ccccc2C1</smiles>

54

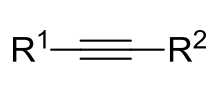

51

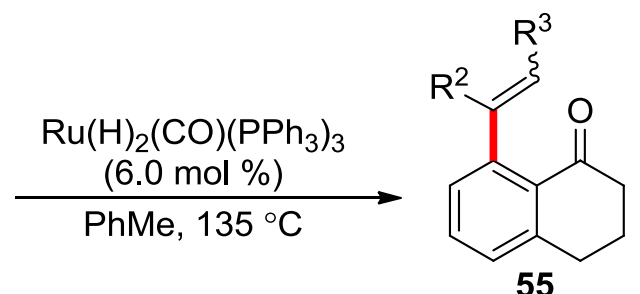

$E / Z=2 / 1-16 / 1$

b) Hydroarylation of heteroaromatic ketone

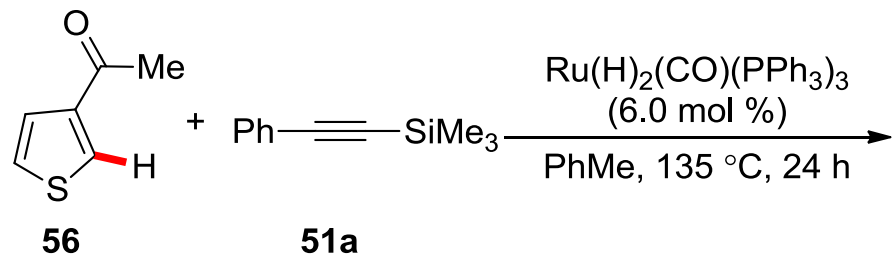

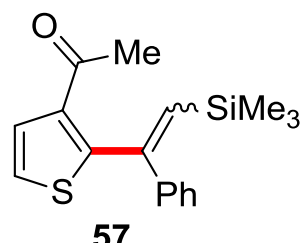

Scheme 19. Ruthenium(0)-catalyzed chelation-assisted hydroarylation of ketones 54.

The hydroarylation of alkynes proceeds via oxidative addition parthway, which introduce a five-membered hydrometallacycle intermediate $\mathbf{6 0}$ (Scheme 20), then the alkyne insertion into the metal-hydride bond of intermediate $\mathbf{6 0}$ occurs and is followed by reductive elimination, giving the final trisubstituted alkene $\mathbf{5 9}$ regenerating the ruthenium(0) catalyst. However, this type of hydroarylation reaction is not completely regio- and stereoselective.

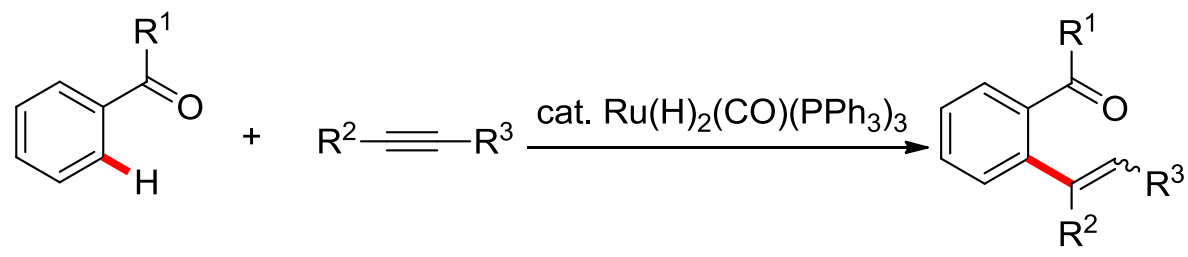

58

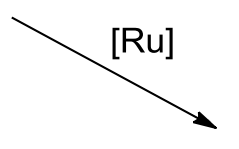<smiles>[R]c1o[R17]([H])c2ccccc12</smiles><smiles>[R]C#[R]CC</smiles>

60

Scheme 20. Mechanism for ruthenium(0)-catalyzed chelation-assisted hydroarylation. 
In recent years, it was clearly revealed that this type of regio- and stereoisomeric issues can be overcome by carrying out the hydroarylation reaction via base-assisted pathway. For instance, Zhang proposed alkenylation reactions of arylpyridines $\mathbf{6 1}$ with terminal alkynes $\mathbf{5 1}$ in the presence of benzoyl peroxide (Scheme 21). ${ }^{[56]}$

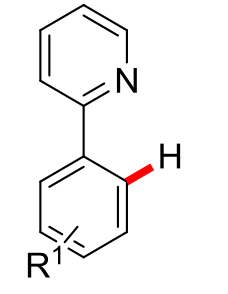

61

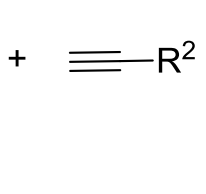

51

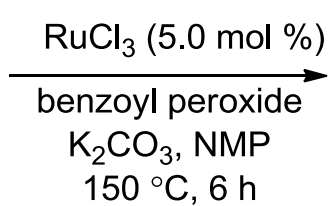

$150{ }^{\circ} \mathrm{C}, 6 \mathrm{~h}$

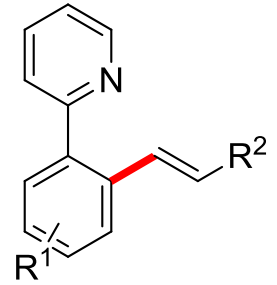

62

Scheme 21. Ruthenium-catalyzed hydroarylations of arylpridines 61.

Subsequently, a significant number of ruthenium-catalyzed hydroarylation reactions via base-assisted $\mathrm{C}-\mathrm{H}$ activation appeared in the literature, and these transformation were rapidly expanded to a variety of directing groups, including benzamides, ${ }^{[53 \mathrm{~b}, 57]}$ isoquinolones, ${ }^{[58]}$ carbamates, ${ }^{[59]}$ among others. ${ }^{[60]}$ In these transformations, substituted arenes reacted with alkynes in the presence of a ruthenium catalyst, giving alkene derivatives in a regio- and stereoselective manner. It is noteworthy that the copper oxidant is inherently not necessary for the hydroarylation reaction.

\subsubsection{Ruthenium-Catalyzed C-H Oxygenation}

During the past few years, ruthenium(II)-catalyzed $\mathrm{C}-\mathrm{H}$ oxygenations of $\mathrm{C}-\mathrm{H}$ bonds were reported by Ackermann and Rao group. ${ }^{[29 a, 61]}$ In contrast, DuBois and coworkers developed a protocol for the selective hydroxylation of tertiary $\mathrm{C}-\mathrm{H}$ bonds that uses catalytic amounts of $\mathrm{RuCl}_{3}$, an inexpensive terminal oxidant $-\mathrm{KBrO}_{3}$, and pyridine as an essential additive (Scheme 22). ${ }^{[62]}$ However, this reaction only has a good selectivity for tetiary $\mathrm{C}-\mathrm{H}$ centers and do not proceed through $\mathrm{C}-\mathrm{H}$ activation, but outer-sphere vadical processes. 

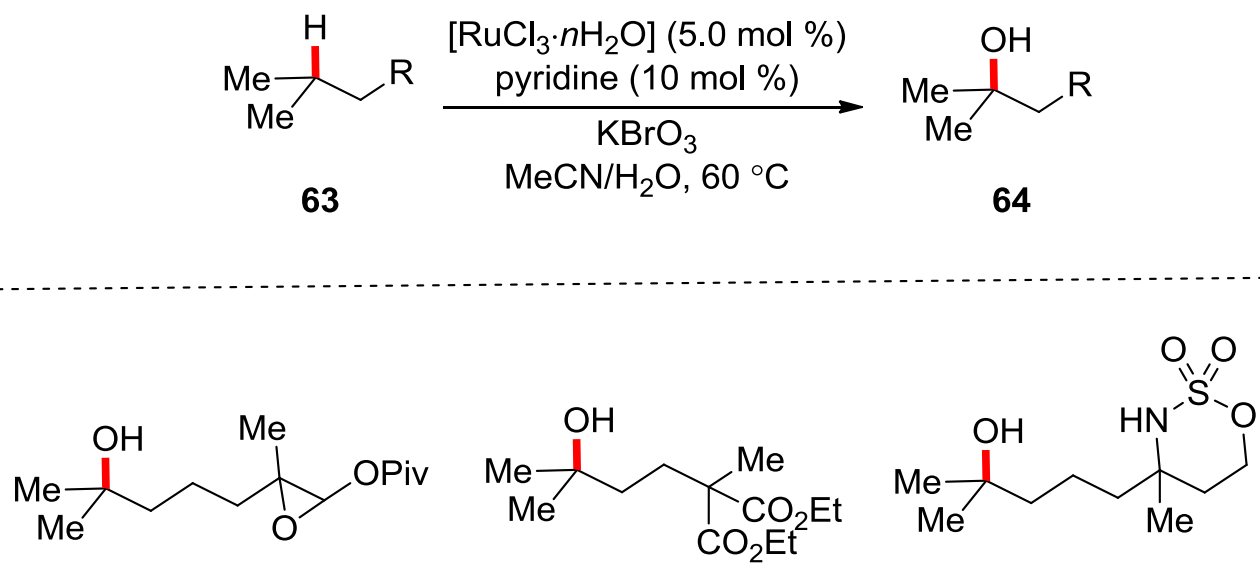

64a: $53 \%$

64b: $70 \%$

64c: $42 \%$

Scheme 22. Ruthenium-catalyzed outer-sphere oxygenation.

However, the Ackermann group developed ruthenium-catalyzed $\mathrm{C}-\mathrm{H}$ oxygenation using $\left[\mathrm{RuCl}_{2}(p \text {-cymene })\right]_{2}$, as well as well-defined ruthenium(II) biscarboxylate complex $\left[\mathrm{Ru}\left(\mathrm{O}_{2} \mathrm{CMes}\right)_{2}(p\right.$-cymene $\left.)\right]$, or even inexpensive $\left[\mathrm{RuCl}_{3} \cdot n \mathrm{H}_{2} \mathrm{O}\right]$ as catalysts, and $\mathrm{PhI}(\mathrm{OAc})_{2}$ as oxidant (Scheme 23a). Around the same time, Rao and co-workers used the complex $\left[\mathrm{RuCl}_{2}(\text { p-cymene })\right]_{2}$ as the precatalyst and $\mathrm{K}_{2} \mathrm{~S}_{2} \mathrm{O}_{8}$ or $\mathrm{HIO}_{3}$ as the oxidant in the oxygenation of $\mathrm{C}-\mathrm{H}$ bonds in arenes (Scheme 23b). ${ }^{[63]}$ TFA/TFAA cosolvent system and oxidants serve as the critical factors for oxygenation of arenes with esters 21. ${ }^{[61 \mathrm{~b}]}$

a) Ackermann, 2012

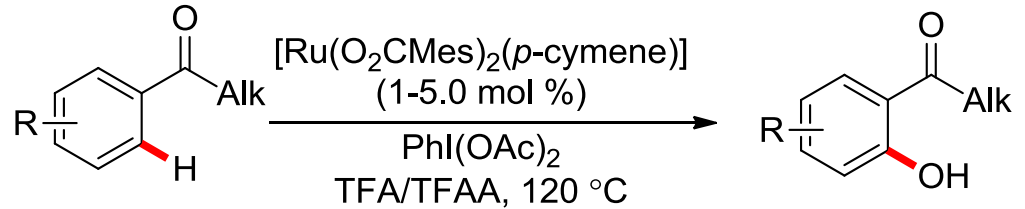

b) Rao, 2012<smiles>[R]OC(=O)c1cc#[R1]cc1</smiles>

21

$\left[\operatorname{RuCl}_{2}(p \text {-cymene })\right]_{2}$

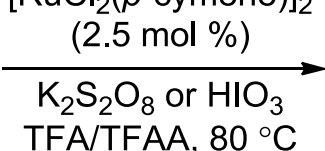

TFA/TFAA, $80^{\circ} \mathrm{C}$<smiles>[R]OC(=O)c1c[R1]ccc1O</smiles>

66

Scheme 23. Ruthenium-catalyzed C-H bond oxygenation of ketones $\mathbf{5 8}$ and esters 21 . 
The group of Ackermann ${ }^{[64]}$ and $\mathrm{Rao}^{[61 \mathrm{a}]}$ further expaned the scope of ruthenium-catalyzed $\mathrm{C}-\mathrm{H}$ oxygenation process to valuable aryl carbamates $\mathbf{6 7}$ and anilides $\mathbf{1 8}$ (Scheme 24).

a) Ackermann, 2013

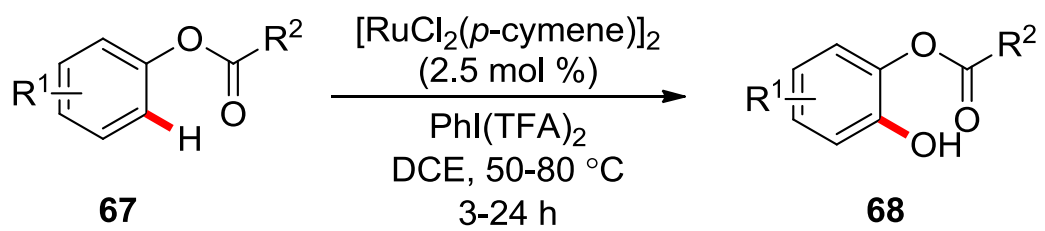

b) Rao, 2013

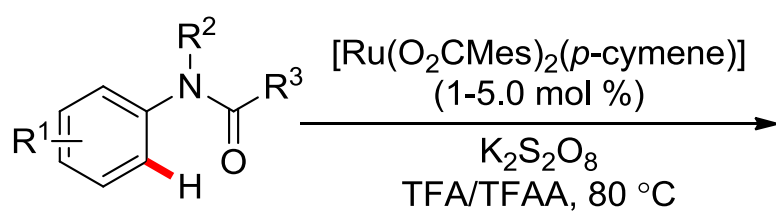

18<smiles>[R]C(=O)N([R])c1cc[R1]cc1O</smiles>

69

Scheme 24. Ruthenium-catalyzed C-H bond oxygenation of aryl carbamates 67 and anilides 18.

In 2014, the Ackermann group reported the first $\mathrm{C}-\mathrm{H}$ oxygenation by assistance of very weakly coordinating aldehydes $\mathbf{2 3}$ using a ruthenium(II) complex as the catalyst (Scheme 25). ${ }^{[65]}$ Under the optimal reaction conditions, electrophilic halide functional groups were well tolerated by the highly chemoselective ruthenium(II) catalyst. 
<smiles>O=Cc1c[R1]ccc1</smiles>

23

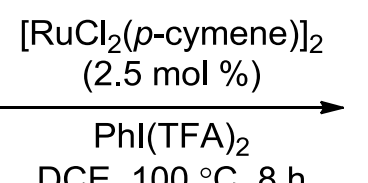

DCE, $100^{\circ} \mathrm{C}, 8 \mathrm{~h}$<smiles>O=Cc1cnccc1O</smiles>

70<smiles>O=Cc1ccccc1Cl</smiles>

70a: $50 \%$<smiles>O=Cc1c(Br)cccc1I</smiles>

70b: $57 \%$<smiles>COc1cc(C=O)ccc1F</smiles>

70c: $60 \%$

Scheme 25. Ruthenium(II)-catalyzed C-H oxygenation of aromatic aldehydes $\mathbf{2 3}$.

Competition studys between arenes with different directing groups clearly showed the challenges that are associated with the use of very weakly coordinating aldehydes (Scheme 26). The success of this reaction highlighted the remarkable power of versatile and mild ruthenium(II) catalysis for the selective functionalization of unactivated $\mathrm{C}-\mathrm{H}$ bonds. 
a) Intermolecular competition experiments<smiles>O=Cc1ccccc1</smiles>

1.0 equiv

23d<smiles>[R]C(=O)c1ccccc1</smiles>

1.0 equiv 58
$\left[\mathrm{RuCl}_{2}(p \text {-cymene })\right]_{2}$ $(2.5 \mathrm{~mol} \%)$

$\mathrm{Phl}(\mathrm{TFA})_{2}$ DCE, $100^{\circ} \mathrm{C}, 8 \mathrm{~h}$<smiles>O=Cc1ccccc1O</smiles>

$70 d$

$65 a^{\prime}$

$\mathrm{R}=\mathrm{N}(\mathrm{iPr})_{2}$

$\mathrm{R}=\mathrm{N}(\mathrm{Me})(\mathrm{OMe})$

$\mathrm{R}=t \mathrm{Bu}$

1

16.4

17.5

6.6

b) Intramolecular competition experiments<smiles>[R]C(=O)c1cccc(C=O)c1</smiles>

71<smiles>CCCCNC(=O)c1ccc(C=O)cc1O</smiles>

72a: $70 \%$

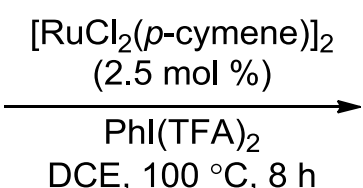

DCE, $100^{\circ} \mathrm{C}, 8 \mathrm{~h}$<smiles>CCOC(=O)c1ccc(C=O)cc1O</smiles>

72b: $13 \%$ (+59\% SM)<smiles>[R]C(=O)c1ccc(C=O)cc1O</smiles>

72<smiles>CC(C)(C)C(=O)c1ccc(C=O)cc1O</smiles>

72c: $76 \%$

Scheme 26: Competition experiments for ruthenium(II)-catalyzed C-H oxygenations of aldehydes 23.

Base on the above reaserch, Hong and co-workers reported ruthenium(II)-catalyzed direct $\mathrm{C}-\mathrm{H}$ oxygenation of flavones and chromones 73 (Scheme 27).<smiles>[R][R]1ccc(-c2cc(=O)c3cnccc3o2)cc1</smiles>

73

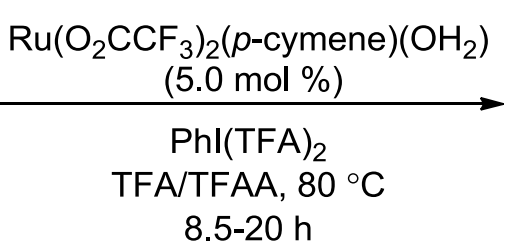

8.5-20 h<smiles>[R][R]1ccc(-c2cc(=O)c3c(o2)=CC=[R1]#CC=3O)cc1</smiles>

74

Scheme 27. Ruthenium(II)-catalyzed C-H oxygenations of flavone and chromone. 
A plausible catalytic cycle was proposed as depicted in Scheme 28. First, the five-membered ruthenacycle $\mathbf{7 7}$ can be formed via the $\mathrm{C}-\mathrm{H}$ bond activation of substrate, and then the ruthenium(IV) species $\mathbf{7 8}$ is formed through the oxidiation by the hypervalent iodine. Subsequent reductive elimination introduce 5-(trifluoroacetyloxy)-flavone $\mathbf{7 9}$ and regenerate the ruthenium(II) catalyst $\mathbf{7 6}$. Finally, the desired product is afforded from the trifluoroacetate $\mathbf{7 4}$ by aqueous work-up.

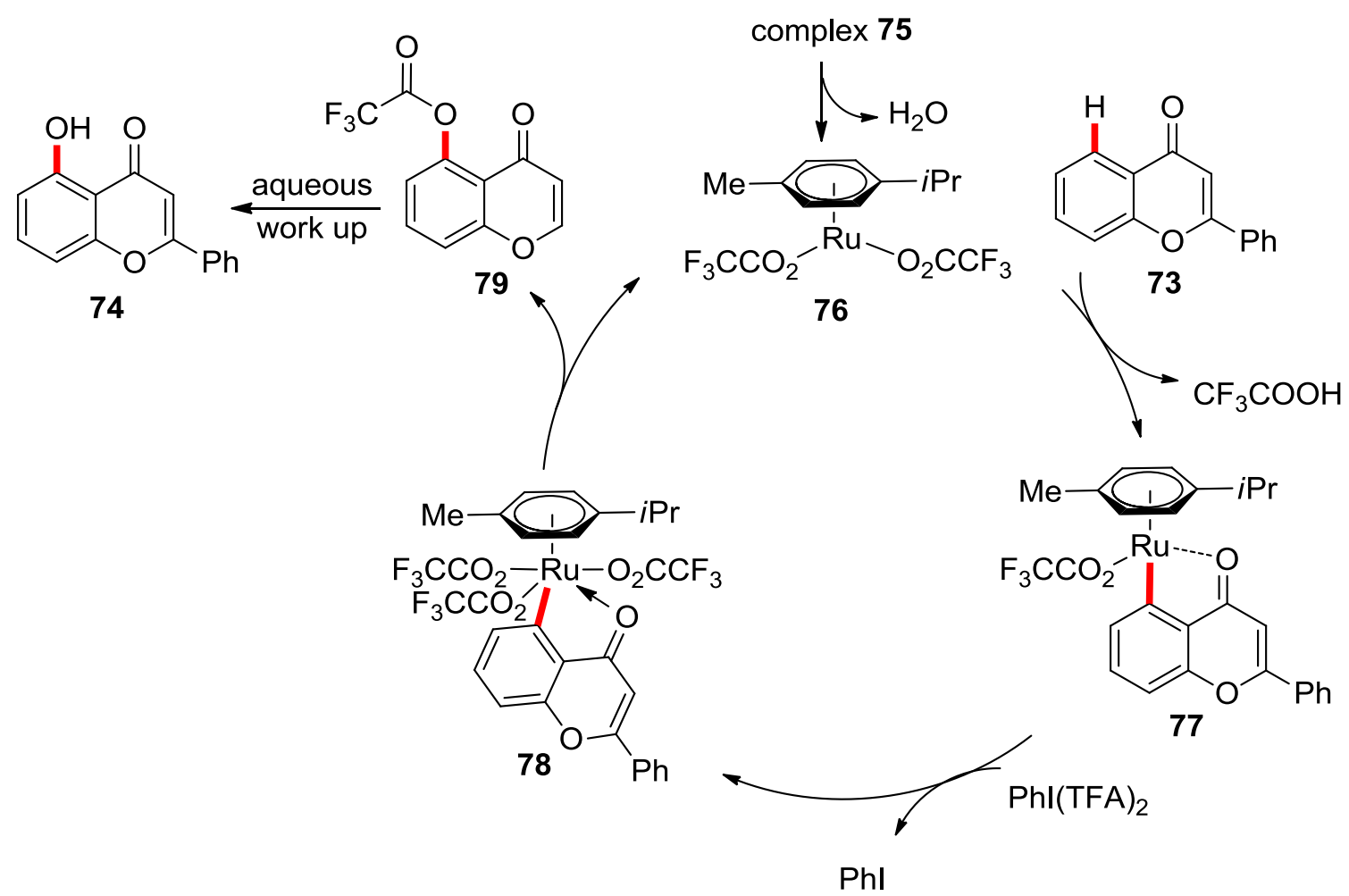

Scheme 28. A proposed mechanistic pathway for ruthenium(II)-catalyzed C-H oxygenations.

\subsection{Cobalt Catalyzed C-H Activation}

Transition metal-catalyzed $\mathrm{C}-\mathrm{H}$ functionalizations are increasingly viable tools for sustainable syntheses. Until now, most of metal-catalyzed $\mathrm{C}-\mathrm{H}$ functionalizations were achieved by second- and third-row transition metals catalyst. ${ }^{[7 \mathrm{a}, 13 \mathrm{a}, 16 \mathrm{a}]}$ Thus, the second-row transition metals, such as ruthenium, palladium and rhodium, have played a major role in $\mathrm{C}-\mathrm{H}$ functionalizations. ${ }^{[3,7 b, 8 c]}$ Despite of the great reactivity, the precious metal complexes are rather expensive and toxic. So the 
development of catalysts based on earth-abundant first-row transition metals catalysts for $\mathrm{C}-\mathrm{H}$ activation reactions that allow mild reaction conditions are meaningful.

Among the first-row transition metals, inexpensive cobalt acted as powerful catalyst and has been successfully used in $\mathrm{C}-\mathrm{H}$ interactive alkylations, arylations, hydroarylations, benzylations and alkenylations. ${ }^{[66]}$ In 1955, Murahashi and co-workers reported an early example of cobalt used in a chelation-assisted $\mathrm{C}-\mathrm{H}$ functionalization reaction. ${ }^{[67]}$ The reaction of a benzaldimine $\mathbf{8 0}$ with carbon monoxide in the presence of $\mathrm{Co}_{2}(\mathrm{CO})_{8}$ at extremely high temperature and pressure thus afforded phthalmidine $\mathbf{8 1}$ (scheme 29a). Later, it was found that under similar reaction conditions, azobenzene 82a reacted with carbon monoxide at 150 atmospheres of pressure to form indazolone $\mathbf{8 3}$ (Scheme $29 b){ }^{[68]}$

a)

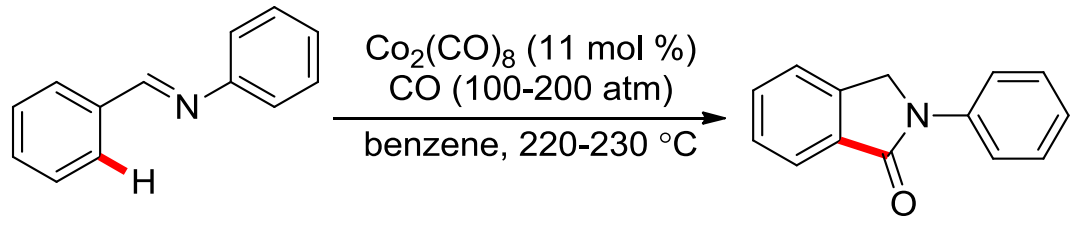

80

81: $80 \%$

b)<smiles>c1ccc(/N=N/c2ccccc2)cc1</smiles>

$82 a$

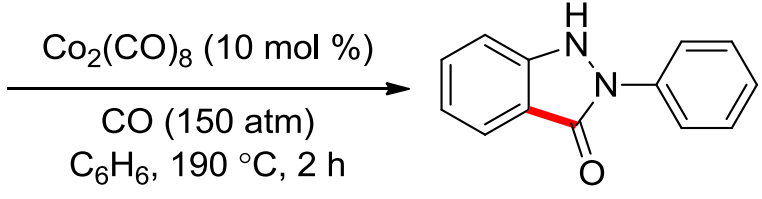

83: $55 \%$

Scheme 29. Cobalt-catalyzed carbonylative cyclization.

While reports of cobalt-catalyzed $\mathrm{C}-\mathrm{H}$ activation were rarely, until in 1994, Kisch and co-workers reported an ortho-alkenylation reaction of an azobenzene derivative $\mathbf{8 2}$ with alkyne $\mathbf{5 1 b}$ using a cobalt(I) catalyst $\mathrm{Co}(\mathrm{H})\left(\mathrm{N}_{2}\right)\left(\mathrm{PPh}_{3}\right)_{3}$ to afford the anti-addition product 84 (Scheme 30). ${ }^{[66 c]}$ 


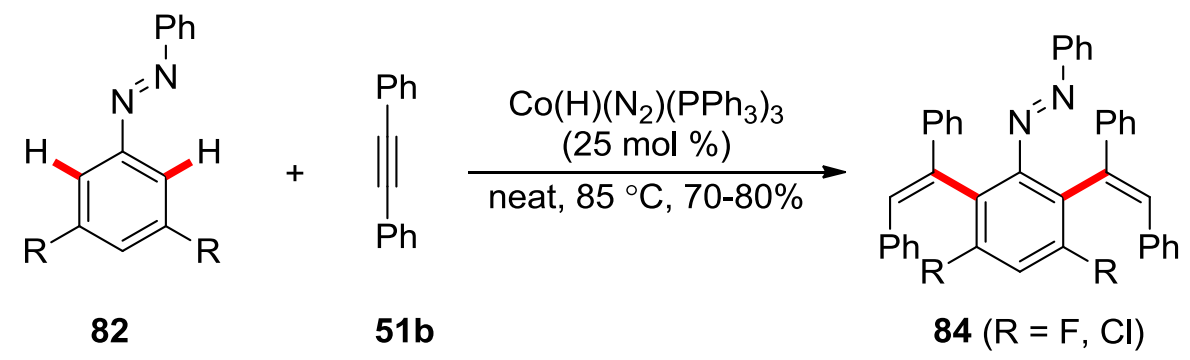

Scheme 30. Cobalt-catalyzed hydroarylation of alkyne 51b with azobenzenes 82.

Around the same time, Klein and co-workers reported an example of well-defined cyclometalation reaction using $\mathrm{Co}(\mathrm{Me})\left(\mathrm{PMe}_{3}\right)_{4}$ and azobenzene 82a through a stoichiometric $\mathrm{C}-\mathrm{H}$ activation (Scheme 31). ${ }^{[69]}$ Based on these findings, their group reported the synthesis of cobaltacycles by $\mathrm{C}-\mathrm{H}$ activation, directed by aromatic and olefinic substrates bearing nitrogen, oxygen, sulfur, and phosphorus directing groups. Those findings implied that cobalt have significant potential for catalytic $\mathrm{C}-\mathrm{H}$ functionalization, particularly for directed ortho $\mathrm{C}-\mathrm{H}$ functionalization of arenes.<smiles>c1ccc(/N=N/c2ccccc2)cc1</smiles>

$82 a$

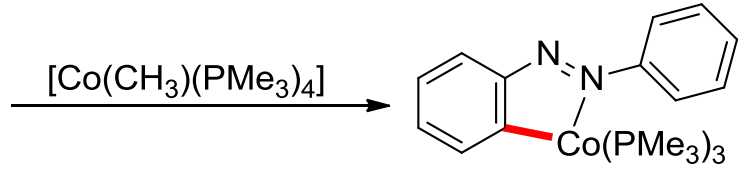

85

Scheme 31. Stoichiometric formation of cobaltacycle 85 through $\mathrm{C}-\mathrm{H}$ activation.

\subsubsection{Low-Valent Cobalt Catalyzed C-H Activation}

Since the first cobalt-catalyzed hydroarylation of alkynes using cobalt(I) complex (Scheme 30$)$, ${ }^{[66 c]}$ the development of cobalt-catalyzed hydroarylation of alkynes and olefins gained a significant attention during the last few years. Especially through the work of Yoshikai and co-workers, who in 2011, reported similar addition reactions of arylpyridines 61a to internal alkynes 51c to give trisubstituted olefins 86 in the presence of $\mathrm{CoBr}_{2}$ as the catalyst, the phosphine ligand $\mathrm{PMePh}_{2}$ and the stoichiometric reductant $\mathrm{MeMgCl}$ (Scheme 32a). ${ }^{[70]}$ Furthermore, their group managed to expand 
the scope of aromatic substrates to include aryl imines 87. ${ }^{[71]}$ Trisubstituted olefins 59 were hence obtained at room temperature (Scheme 32b). Potentially sensitive chloro and cyano substituents in substrates 87d and 87e were well tolerated. It is worth noting that the substrates bearing $m$-methoxy, $m$-chloro, $m$-cyano and $m$-fluoro substituents $\mathbf{8 7 c - 8 7 f}$ reacted preferentially at the more sterically hindered C2-positions.

a)

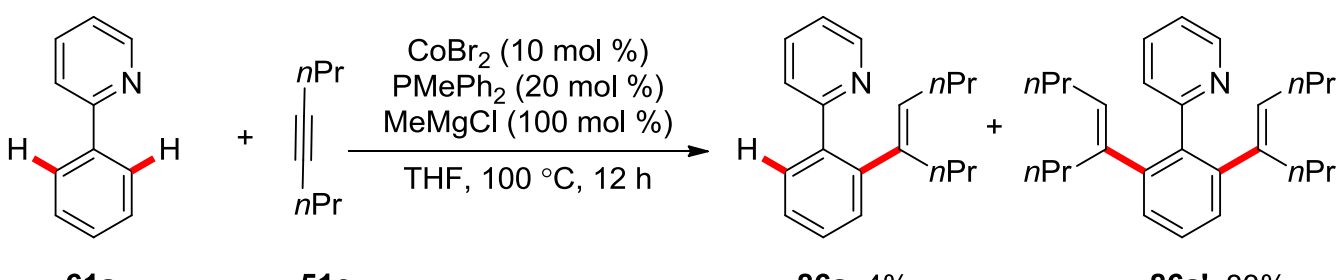

$61 \mathrm{a}$

$51 \mathrm{c}$

86a: $4 \%$

86a': $83 \%$

b)

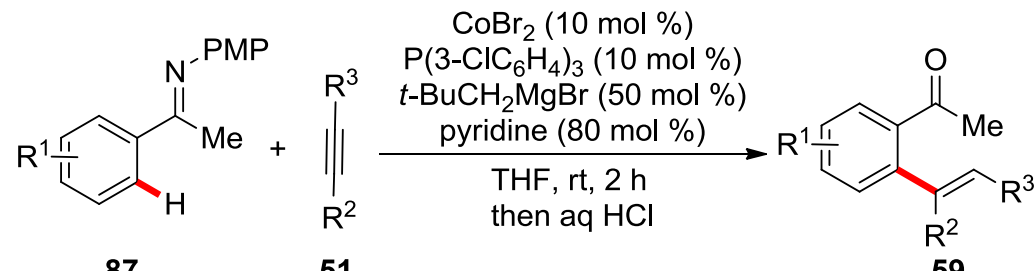

87

51

59<smiles>[R]CP/C=C(\P)c1ccc([R])cc1C(C)=O</smiles>

$\mathrm{R}^{1}=\operatorname{Me}(\mathbf{5 9 a}): 73 \%$

$\mathrm{R}^{1}=\mathrm{CF}_{3}$ (59b): $80 \%$

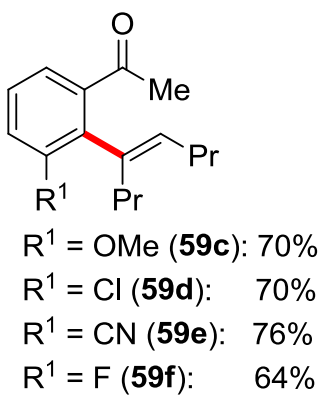

Scheme 32. Cobalt-catalyzed hydroarylation of alkynes 51.

With the successful development of alkyne hydroarylation reactions, the hydroarylation of olefins also proved to be viable by low valent cobalt catalysis. Hence, Yoshikai and co-workers explored the addition reaction of 2-phenylpyridine (61a) to styrene (32a) under conditions similar to hydroarylation of alkynes. A cobalt catalyst generated from $\mathrm{CoBr}_{2}, \mathrm{PCy}_{3}$, and $\mathrm{Me}_{3} \mathrm{SiCH}_{2} \mathrm{MgCl}$ promoted the reaction to afford the branched adduct $\mathbf{8 8 a}$ with high regioselectivity, while the use of 
an NHC ligand instead of $\mathrm{PCy}_{3}$ caused the reversal of the regioselectivity, leading to the formation of the linear adduct $\mathbf{8 8 b}$ (Scheme 33). ${ }^{[72]}$<smiles>c1ccc(CCc2ccccc2-c2ccccc2)cc1</smiles>

88b: $84 \%$ $(\mathrm{b}: \mathrm{l}=3: 97)$

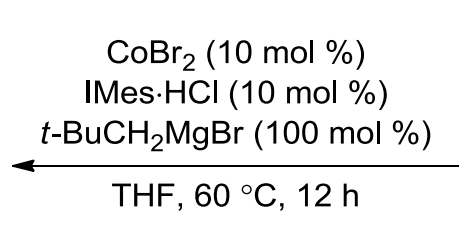<smiles>c1ccc(-c2ccccn2)cc1</smiles>

$61 \mathrm{a}$

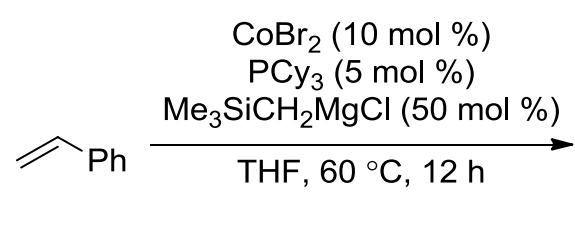

$32 a$

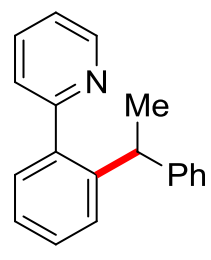

88a: $88 \%$ $(b: I=96: 4)$

Scheme 33. Cobalt-catalyzed hydroarylation of 2-phenylpyridine 61.

A mechanism addressing these findings was proposed (Scheme 34). First, reversible oxidative addition of the ortho $\mathrm{C}-\mathrm{H}$ bond to cobalt takes place, then reversible insertion of styrene 32a into the $\mathrm{Co}-\mathrm{H}$ bond occurs leading to a branched or a linear intermediate 89a or 89b. This is followed by reductive elimination to form the 1,1- or 1,2-diarylethane $\mathbf{8 8 a}$ or $\mathbf{8 8 b}$ and regenerate the cobalt species. 

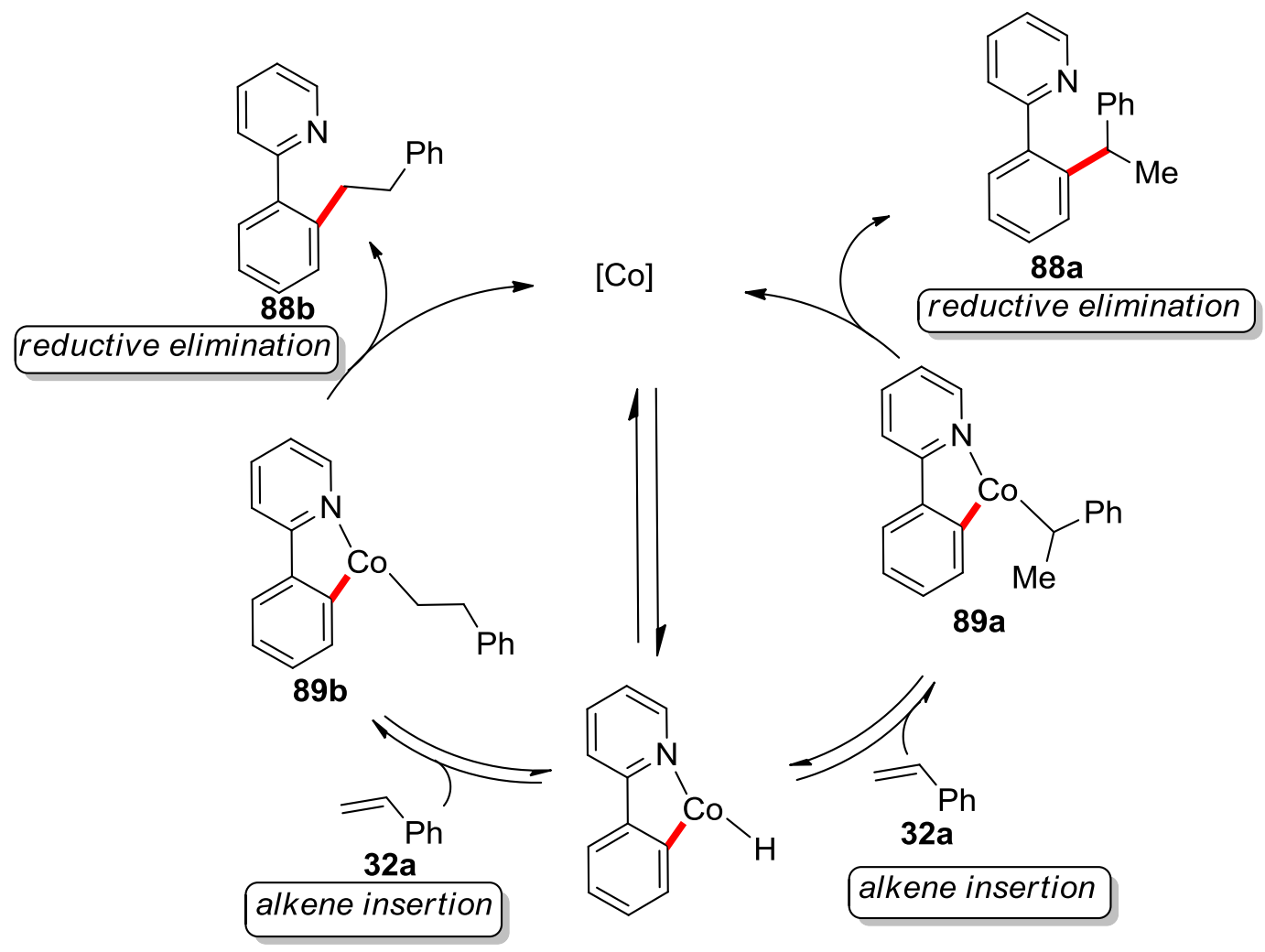

Scheme 34. Proposed catalytic cycles for cobalt-catalyzed hydroarylations of styrenes $\mathbf{3 2}$.

Based on the above research, a protocol for the synthesis of alkylated arenes by cobalt catalysis was viable through hydroarylations of alkenes. Synthesis of alkylated arenes was also successful through cobalt-catalyzed $\mathrm{C}-\mathrm{H}$ alkylations with organic electrophiles, such as alkyl halides. ${ }^{[73]}$ In 2011 , a cobalt-catalyzed ortho-alkylation using alkyl chlorides 90 as alkyl regent was reported. In this catalytic system, the alkylation of benzamides $\mathbf{9 1}$ was accomplished with various alkyl chlorides $\mathbf{9 0}$, notaly without NHC or phosphine ligand (Scheme 35$).{ }^{[74]}$ 
<smiles>[R]C=CC(=CC=[R])C(=O)NC</smiles>

18

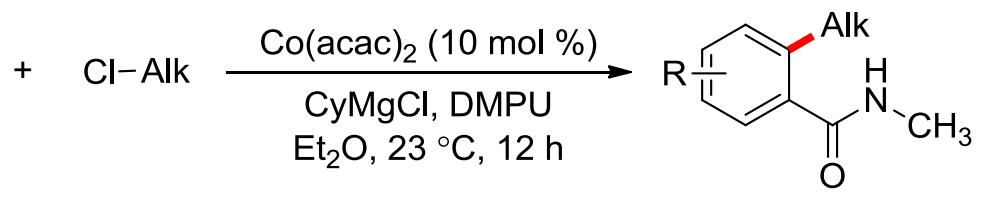

90<smiles>CCCCc1ccc(-c2ccccc2)cc1C(=O)NC</smiles>

91a: $81 \%$<smiles>CCCCc1ccc2ccccc2c1C(=O)NC</smiles>

91b: $64 \%$<smiles>CNC(=O)c1cc(-c2ccccc2)ccc1CCCC1(C)OCCO1</smiles>

91c: $64 \%$<smiles>CNC(=O)c1cc(-c2ccccc2)ccc1CCn1cccc1</smiles>

91d: $59 \%$

Scheme 35. Cobalt-catalyzed direct alkylation of benzamides 18 .

Later, the Ackermann group reported first $\mathrm{C}-\mathrm{H}$ arylation reactions with organic electrophiles. The catalytic system consisting of $\mathrm{Co}(\mathrm{acac})_{2}, \mathrm{IMesHCl}$ as a $\mathrm{NHC}$ precursor and cyclohexylmagnesium chloride allowed for the arylation of arylpyridines 61 with organic electrophiles, such as phenol derived aryl carbamates 92a, sulfamates $\mathbf{9 2 b}$, as well as aryl chlorides 92c. (Scheme 36a). ${ }^{[75]}$ Furthermore, the Yoshikai group contributed to extend the scope of cobalt-catalyzed $\mathrm{C}-\mathrm{H}$ arylation with organic electrophiles by using ketimines $\mathbf{8 7}$ as the directing groups (Scheme $36 \mathrm{~b}) .{ }^{[76]}$ 
a) Ackermann, 2012<smiles>[R1]1ccccc1-c1ccccn1</smiles><smiles>[R][R]1ccc([X])cc1</smiles>
$\mathrm{Co}(\mathrm{acac})_{2}(5-10 \mathrm{~mol} \%)$ $\stackrel{\text { IMes. } \mathrm{HCl}(20 \mathrm{~mol} \%)}{\text { CyMgCl, DMPU }}$ $\mathrm{Et}_{2} \mathrm{O}, 23-60{ }^{\circ} \mathrm{C}, 12 \mathrm{~h}$<smiles>[R]c1[R]cc(-c2ccccc2-c2ccccn2)cc1</smiles><smiles>COc1cc(C)ccc1-c1ccc(C)cc1-c1ccccn1</smiles><smiles>COc1ccc(-c2c(F)cccc2-c2ccccn2)cc1</smiles><smiles>FC(F)(F)c1ccc(-c2cc(C(F)(F)F)ccc2-c2ccccn2)cc1</smiles>

$X=\mathrm{OSO}_{2} \mathrm{NMe}_{2}$ (93a): $83 \% \quad X=\mathrm{OC}(\mathrm{O}) \mathrm{NMe}_{2}(\mathbf{9 3 b}): 90 \%$

b) Yoshikai, 2012<smiles>[Y6]N=C(C)c1ccccc1[CH+]</smiles>

87<smiles>Clc1cc[R]cc1</smiles>

92c

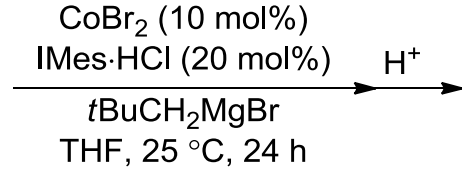

THF, $25^{\circ} \mathrm{C}, 24 \mathrm{~h}$<smiles>[R][R]1=C=[R1]=CC=C1c1ccccc1</smiles>

94

Scheme 36. Cobalt-catalyzed C-H arylation of arylpyridines 61 and ketimines 87.

Apart from alkylation and arylation reactions, ${ }^{[74,75]}$ Ackermann and co-workers showed that low valent cobalt catalysis could be applied for the $\mathrm{C}-\mathrm{H}$ alkenylation of arenes. In 2015, Ackermann and co-workers presented the first direct alkenylation of (hetero)arenes 95 with easily accessible enol esters 96 (Scheme 37). Under optimal reaction conditions highlighting $10 \mathrm{~mol} \% \mathrm{CoI}_{2}, 10 \mathrm{~mol} \%$ preligand IPrHCl, 2.0 equivalent of base in DMPU, a varieties of differently substituted heteroarenes 95 were successfully alkenylated. ${ }^{[77]}$ Pleasantly, 2-pyridylferrocene $\mathbf{9 5 g}$ was successfully alkenylated as well, giving the alkenyl ferrocene $\mathbf{9 7}$. 

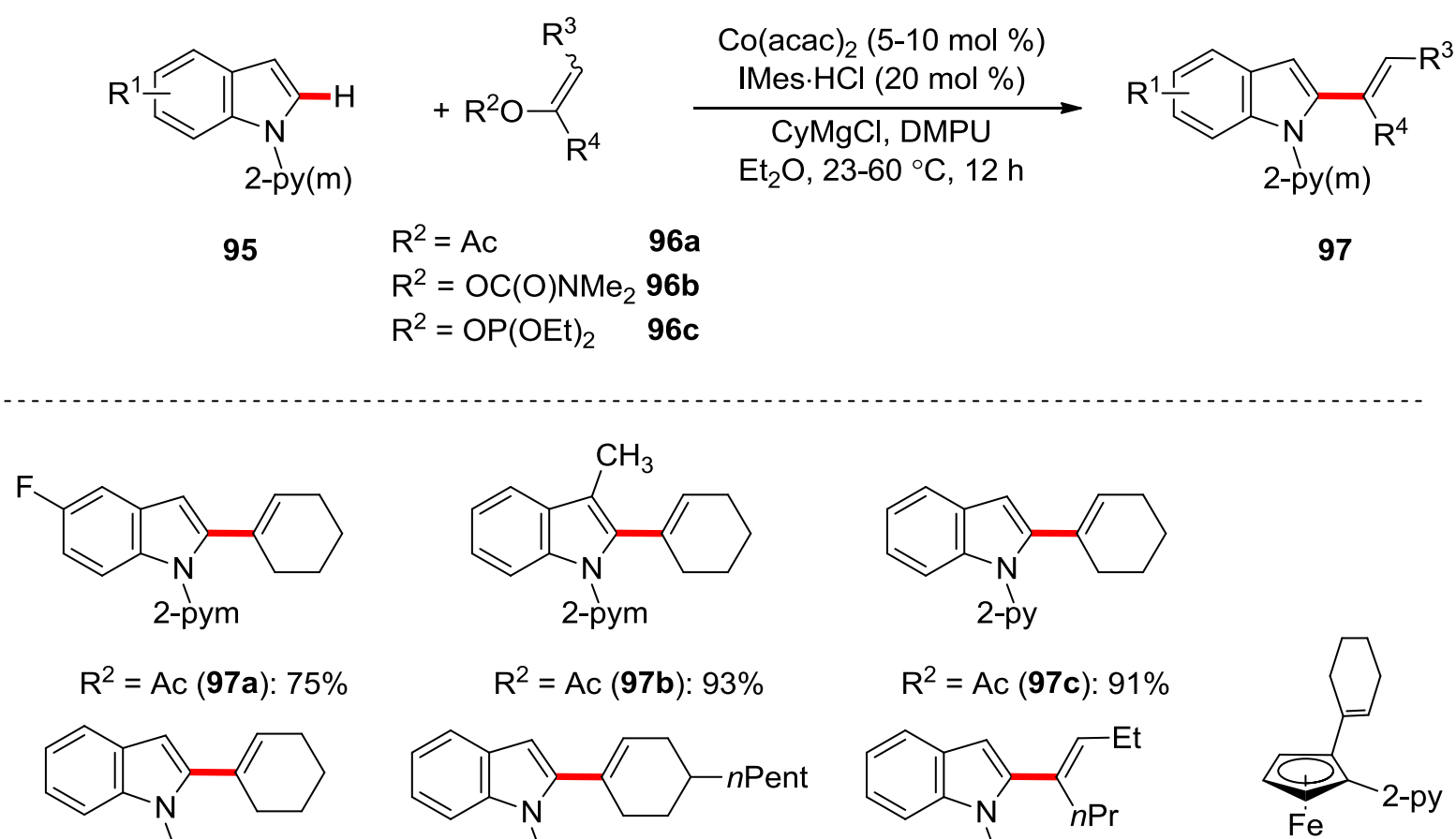

2-pym

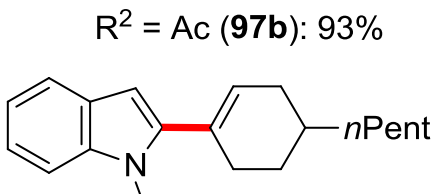

2-pym
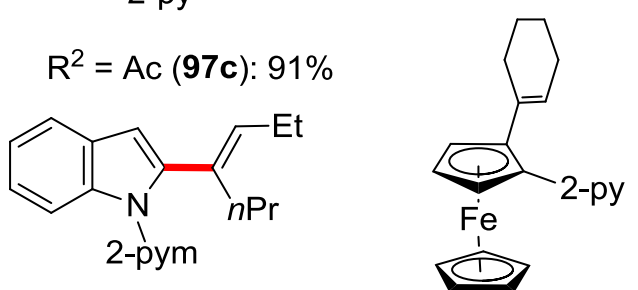

$R^{2}=A c(97 d): 88 \%$

$\mathrm{R}^{2}=\mathrm{OC}(\mathrm{O}) \mathrm{NMe}_{2}(\mathbf{9 7 e}): 82 \%$

$R^{2}=\mathrm{OP}(\mathrm{OEt})_{2}(\mathbf{9 7 f}): 88 \% R^{2}=\mathrm{Ac}(\mathbf{9 7 g}): 48 \%$

Scheme 37. Cobalt-catalyzed C-H alkenylation of heteroarenes 95.

\subsubsection{High Valent Cobalt(III)-Catalyzed C-H Activation}

In recent years, $\mathrm{C}-\mathrm{H}$ activation using $\mathrm{Cp} * \mathrm{Rh}(\mathrm{III})$-based catalysts has underwent a remarkable development, a variety of $\mathrm{C}-\mathrm{C}, \mathrm{C}-\mathrm{N}$, and $\mathrm{C}-\mathrm{O}$ bond formation by means of $\mathrm{C}-\mathrm{H}$ activation have been achieved under oxidative conditions. ${ }^{[8 \mathrm{~b}, 8 \mathrm{c}]}$ Although $\mathrm{Cp} * \mathrm{Rh}^{\mathrm{III}}$-catalyzed processes are useful and versatile, their high cost limites futher applications. Hence, it is necessary to search for an inexpensive base metal catalyst as an alternative to the cationic rhodium catalysis. ${ }^{[78,8 b, 8 c]}$ In 2013 , Kanai and co-workers found that a cationic high-valent cobalt complex $\left[\mathrm{Cp}^{*} \mathrm{Co}^{\mathrm{III}}(\right.$ arene $\left.)\right]\left(\mathrm{PF}_{6}\right)_{2} \mathbf{1 0 0}$ promoted the addition of 2 -aryl pyridines 61 to imines 98, enones 101a, and $\alpha, \beta$-unsaturated $N$-acyl pyrroles 101b as ester and amide surrogates (Scheme 38 ). ${ }^{[79]}$ It is worth noting that $\beta$-substituted $\alpha, \beta$-unsaturated esters and amides have not been used successfully in the corresponding direct 
addition of a $\mathrm{C}-\mathrm{H}$ bond catalyzed by $\mathrm{Cp} * \mathrm{Rh}^{\mathrm{III}}$ complexes, which indicated the unique reactivity profile of cobalt(III)-catalysis.

a)

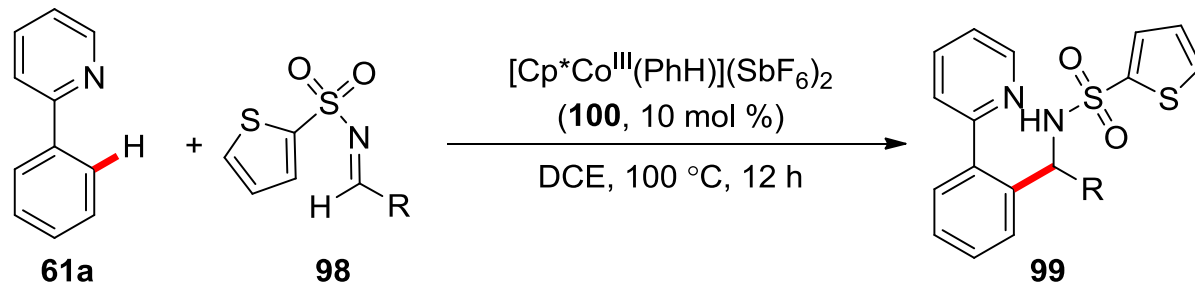

b)

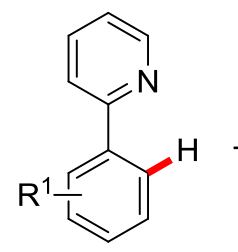

61

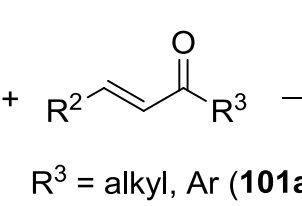
or pyrrol-1-yl (101b)

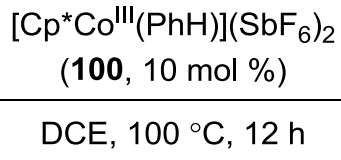

$\left[\mathrm{Cp}^{*} \mathrm{Co}^{\prime \prime \prime \prime}(\mathrm{PhH})\right]\left(\mathrm{SbF}_{6}\right)_{2}$ $(\mathbf{1 0 0}, 10 \mathrm{~mol} \%)$

DCE, $100^{\circ} \mathrm{C}, 12 \mathrm{~h}$<smiles>[R]C(=O)CC([R])c1ccccc1-c1ccccn1</smiles>

102

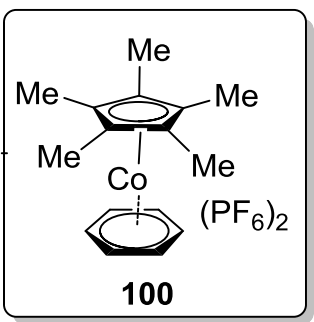

Scheme 38. Cobalt(III)-catalyzed addition reaction of 2-arylpyridines 61 to imines 98 and $\alpha, \beta$-unsaturated ketones 101.

Later, their group developed a C2-selective indole 103 alkenylation/annulation sequence proceeded smoothly in the presence of cobalt complex 100 and KOAc, giving pyrroloindolones 104 in 58-89\% yield. By changing the directing group and reaction conditions selectivity alkenylation product $\mathbf{1 0 5}$ can be obtained (Scheme 39). ${ }^{[8]}$ In contrast, $\mathrm{Cp} * \mathrm{Rh}(\mathrm{III})$-based catalysts did not afford annulation products under any of the investigated conditions, and only the alkenylation product was observed here. This result highlighted the unique nucleophilic activity of the organocobalt species. 


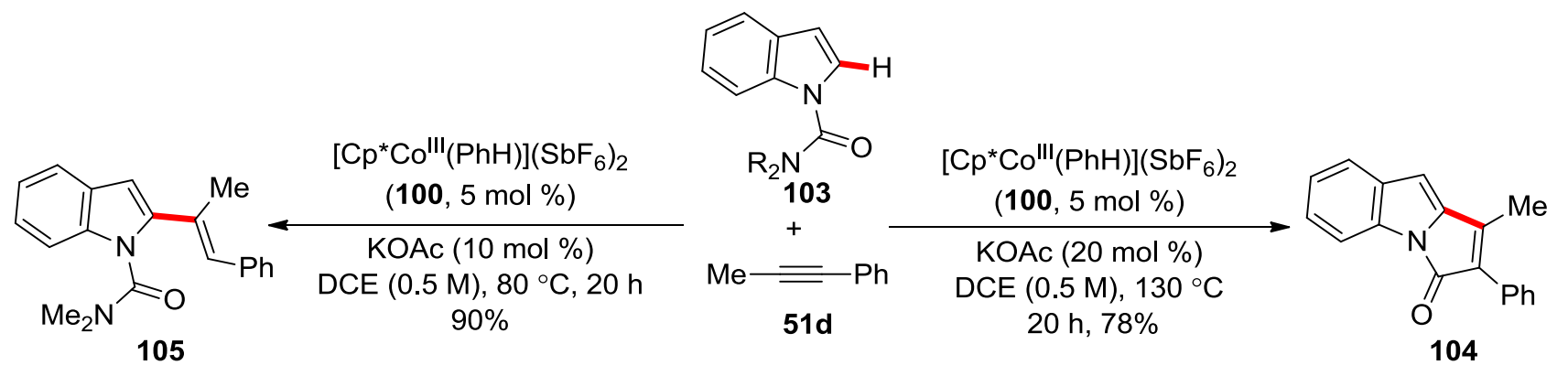

Scheme 39. Cobalt(III)-catalyzed chemoselective C-H alkenylation/annulation of indoles $\mathbf{1 0 3 .}$

Futhermore, the authors proposed a catalytic cycle (Scheme 40). The catalytically active monocationic species 106 was formed by a ligand exchange from cobalt comple 100. Subsequently, a reversible metalation delivers the cobaltacycle $\mathbf{1 0 8}$ via an acetate-assisted $\mathrm{C}-\mathrm{H}$ activation mechanism. Then by insertion of alkyne 51d into the $\mathrm{Co}-\mathrm{C}$ bond delivers the seven-membered cobaltacycle intermiedate 109. Next, two ways are possible depending on the directing group, the annulation product $\mathbf{1 0 4}$ was formed by release of morpholine, or protodemetalation delivers the alkenylated indole $\mathbf{1 0 5}$ and regenerates the active monocationic species $\mathbf{1 0 6}$. 


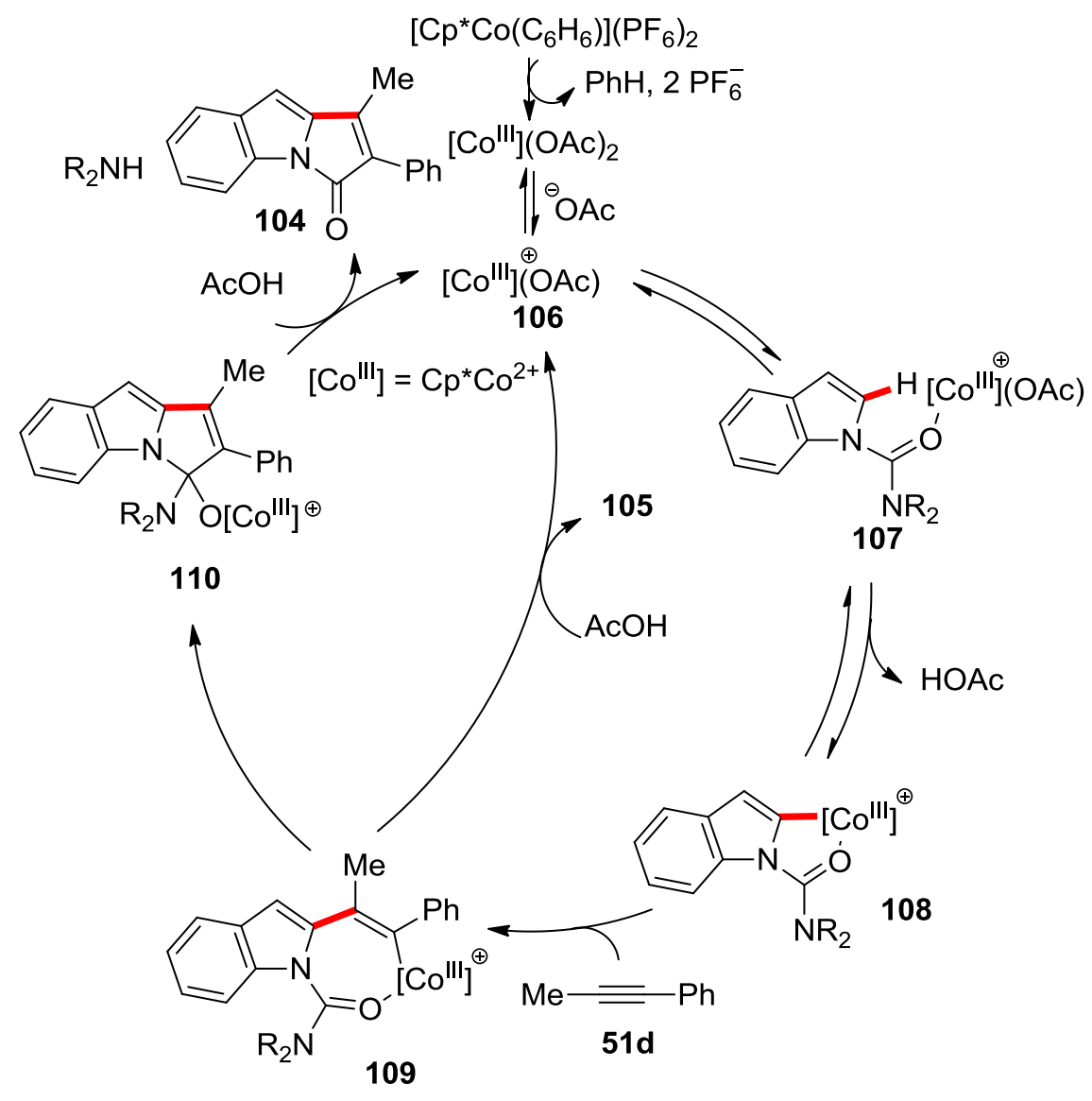

Scheme 40. Proposed catalytic cycle for cobalt(III)-catalyzed hydroarylation/annulation reaction.

Encouraged by the addition reaction of 2-aryl pyridines to amines, ${ }^{[79]}$ the Ellman group reported $\mathrm{Cp}^{*} \mathrm{Co}^{\mathrm{III}}$-catalyzed addition of $\mathrm{C}-\mathrm{H}$ bond to aldehydes $\mathbf{2 3}$ to obtain heterocycles. Various indazoles 112 and furans 114 were synthesized from azobenzene 82 and $\alpha, \beta$-unsaturated oxime ethers 113 with aldehydes 23 (Scheme 41). ${ }^{[81]}$ 
a) indazoles

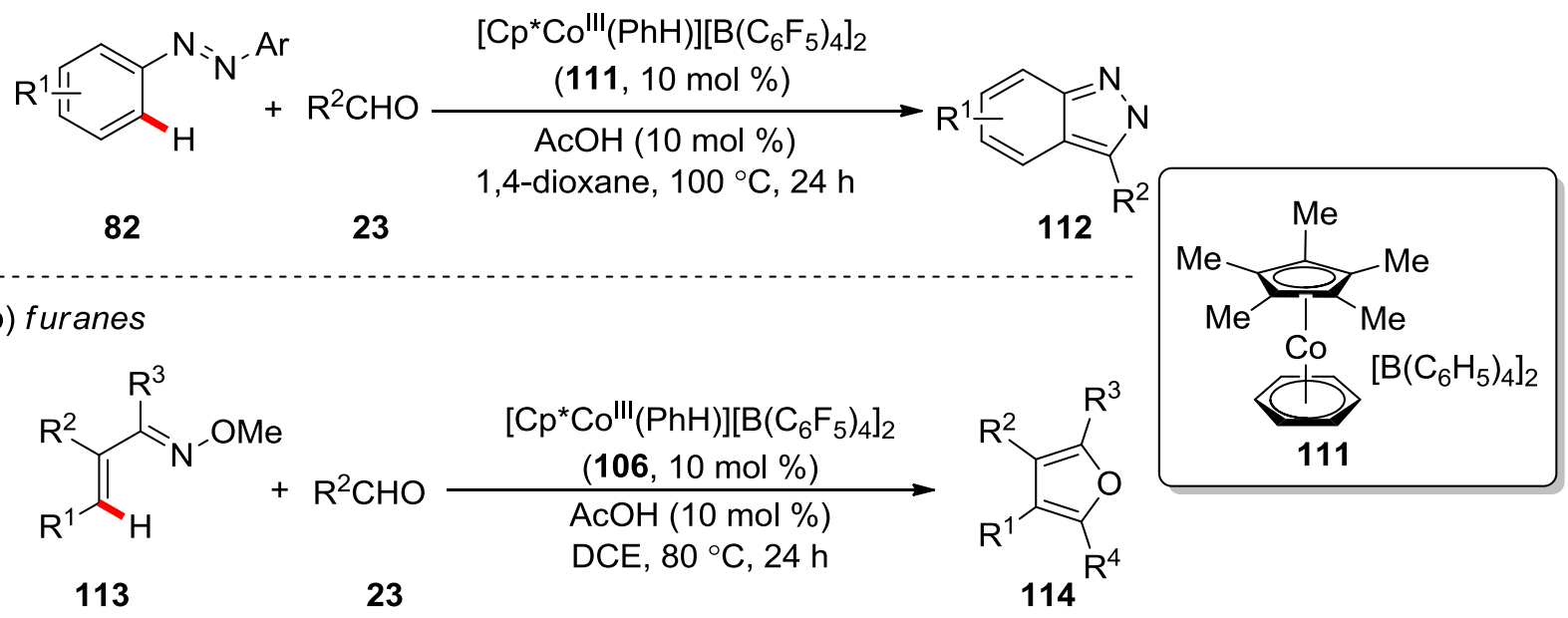

Scheme 41. Cobalt(III)-catalyzed synthesis of indazoles 112 and furans 114.

In addition, the isohypsic synthesis of heterocyles, such as quinolines $\mathbf{1 1 6},{ }^{[82]}$ isoquinolines $\mathbf{1 1 7},{ }^{[83]}$ indenones 118, ${ }^{[84]}$ indoles $\mathbf{1 0 3},{ }^{[85,81 \mathrm{~b}]}$ by cobalt(III)-catalyzed $\mathrm{C}-\mathrm{H}$ functionalizations proved viable (Scheme 42). These transformations employed anilides 16, oximes $\mathbf{8 7 b}$, benzoates $\mathbf{2 1}$, nitrones $\mathbf{1 1 5}$, as the directing groups, respectively. The synthesis of heterocyles proceeded smoothly in the presence of $\mathrm{Cp} * \mathrm{Co}$ (III) complexes and silver additives in good yields. These reports demonstrated that $\mathrm{Cp} * \mathrm{Co}(\mathrm{III})$ is a prominent catalyst for tandem alkenylation/nucleophilic addition reactions. 


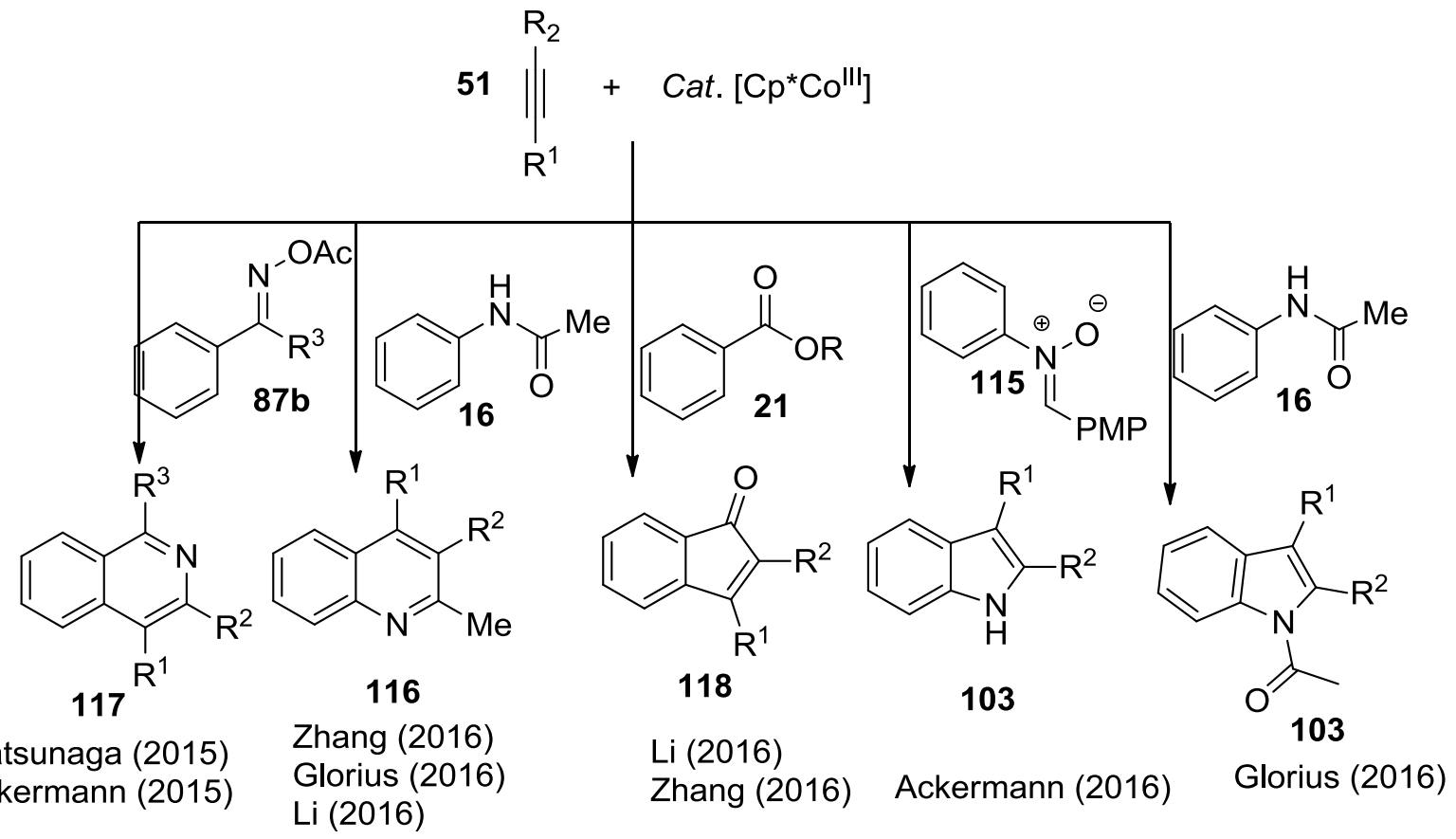

Scheme 42. Cobalt(III)-catalyzed synthesis of heterocyles.

$\mathrm{Cp} * \mathrm{Co}$ (III) complexes, as have been shown above, have successfully been used in $\mathrm{C}-\mathrm{H}$ hydroarylation and annulation reactions. Later, the Kanai group found that the air-stable $\left[\mathrm{Cp}^{*} \mathrm{CoI}_{2}(\mathrm{CO})\right]$ complex 120, which was first prepared by Li and Jin in $2004,{ }^{[86]}$ could be applied for $\mathrm{C} 2$ selective $\mathrm{C}-\mathrm{H}$ amidation of indoles 95 with sulfonyl azides 119 (Scheme 43). ${ }^{[87]}$

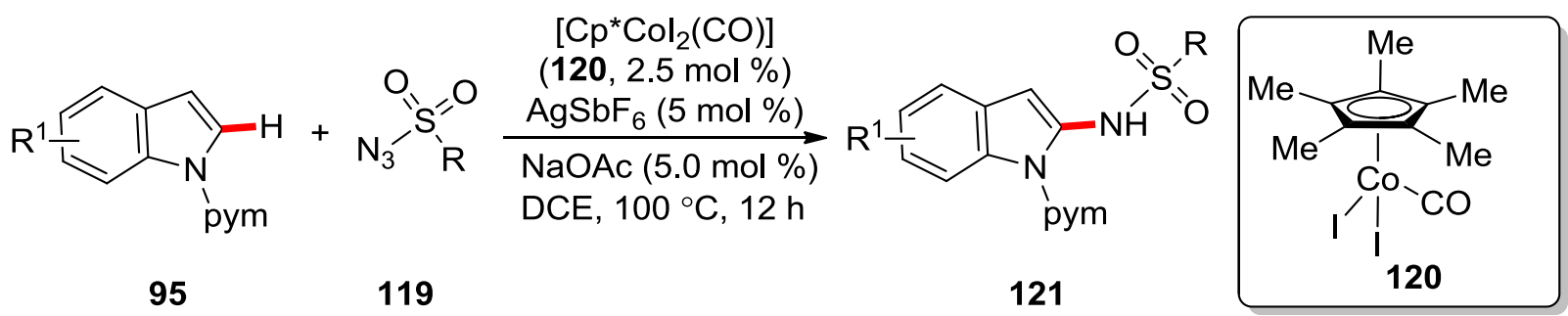

Scheme 43. Cobalt(III)-catalyzed C2 selective amidation of indoles 95.

In 2015, the Ackermann group reported the $\mathrm{Cp} * \mathrm{Co}(\mathrm{III})$-catalyzed $\mathrm{C}-\mathrm{H}$ cyanation of arenes 95 using $N$-cyano- $N$-phenyl- $p$-toluenesulfonamid (122) as an easy to handle cyanating reagent (Scheme 44$)$. 
The $\mathrm{C}-\mathrm{H}$ cyanation proved to be highly chemo- and regioselective in the presence of $2.5 \mathrm{~mol} \%$ of $\left[\mathrm{Cp}^{*} \mathrm{CoI}_{2}(\mathrm{CO})\right], 5 \mathrm{~mol} \%$ of $\mathrm{AgSbF}_{6}$, and $5 \mathrm{~mol} \%$ of KOAc (Scheme 44a). ${ }^{[88]}$ Thereafter, the Glorius group also developed cobalt-catalyzed cyanation under similar conditions. They also achieved cobalt-catalyzed $\mathrm{C}-\mathrm{H}$ allylation using pivalic acid instead of acetate salt as a key catalyst component (Scheme 44b). ${ }^{[89]}$

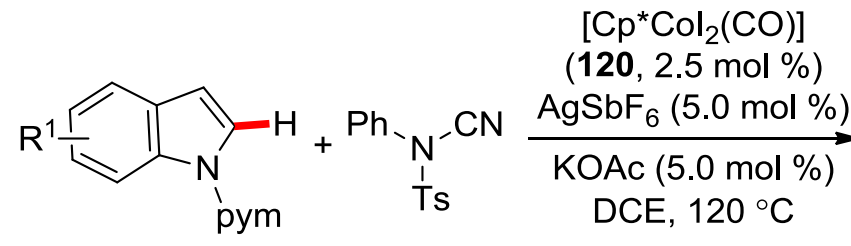

95

122<smiles>N#CC1=Cc2cc[Y1](c2)N1PO</smiles>

123

b) Glorius, 2015

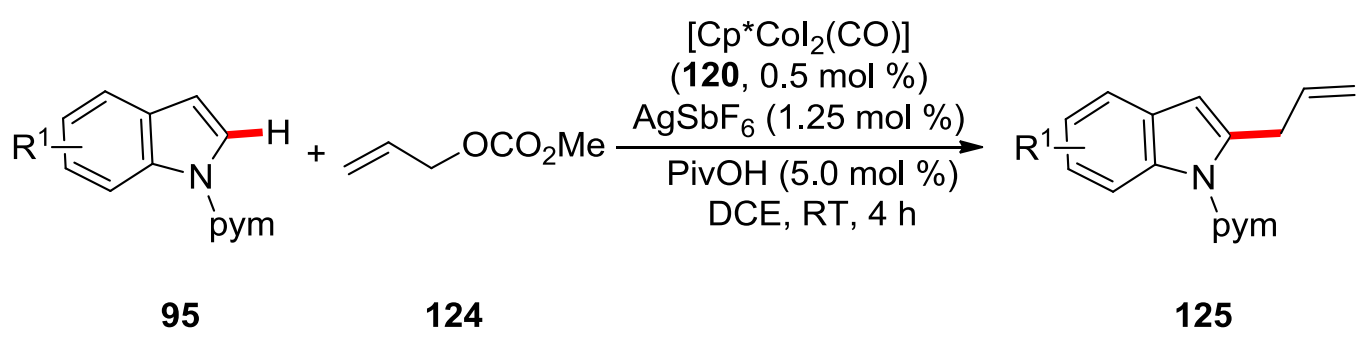

Scheme 44. Cobalt(III)-catalyzed C-H cyanation and allylation.

Based on the experimental results, the Ackermann group proposed a catalytic cycle for the cobalt(III)-catalyzed $\mathrm{C}-\mathrm{H}$ cyanation (Scheme 45 ). The catalytic cycle is intitiated by a reversible $\mathrm{C}-$ $\mathrm{H}$ metalation, involving an acetate-assisted deprotonation pathway to form the cyclometalated complex 127. Subsequently, coordination and insertion of the cyanation reagent $\mathbf{1 2 2}$ provide the intermideate 128 and 129. Then proto-demetalation with the in situ generated acetic acid provides the desired product $\mathbf{1 2 3}$ and regenerates the catalytically active cobalt(III) catalyst $\mathbf{1 2 6}$. 


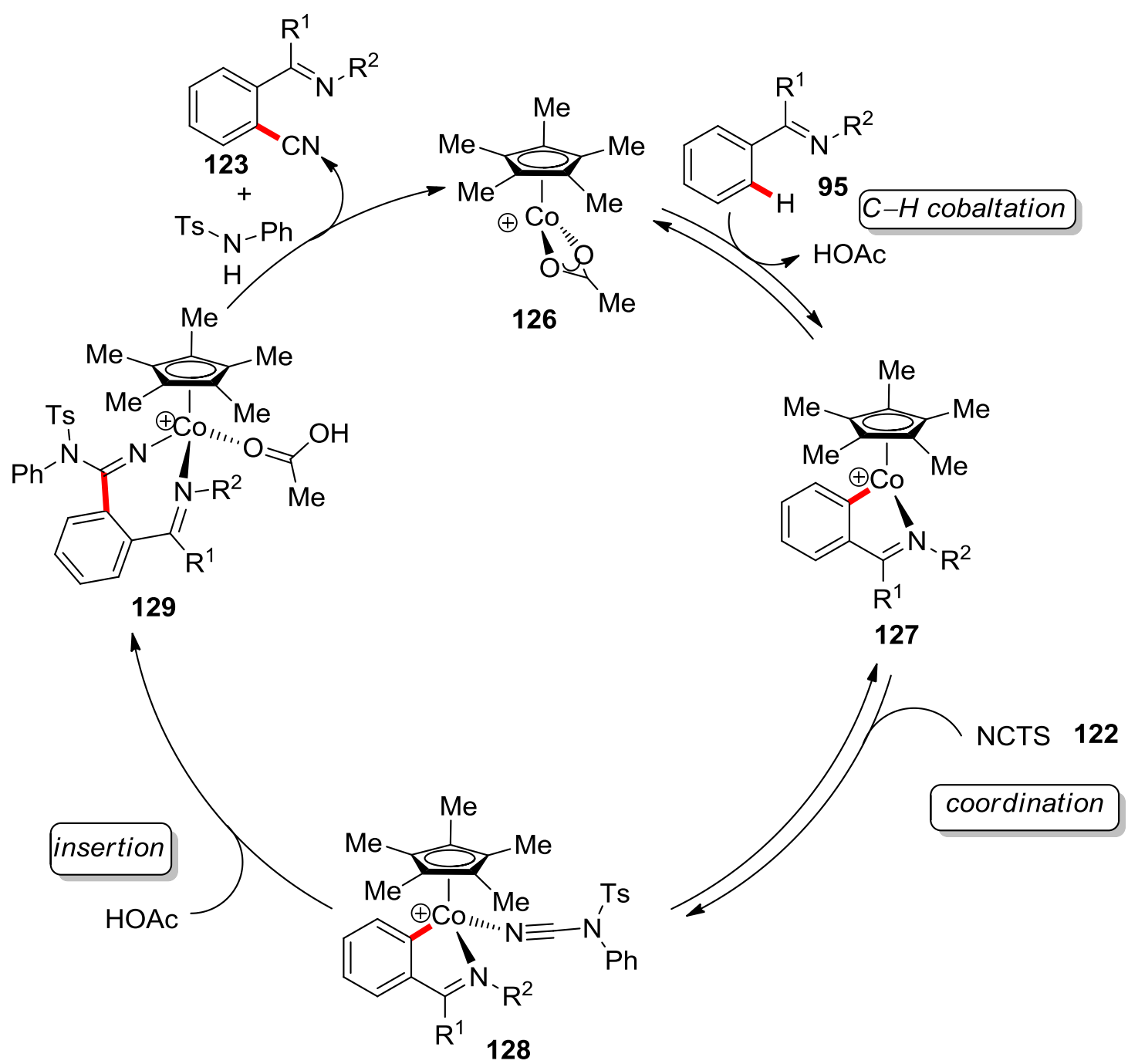

Scheme 45. Proposed catalytic cycle for cobalt(III)-catalyzed cyanation.

Very recently, the Ackermann group developed the cobalt(III)-catalyzed aminocarbonylation of aryl pyrazoles 31 (Scheme 46). ${ }^{[90]}$ The aminocarbonylation with isocyanates $\mathbf{1 3 0}$ as the electrophiles provide high yield under the reaction conditions consist of $5 \mathrm{~mol} \%$ of $\left[\mathrm{Cp} * \mathrm{Co}(\mathrm{CO}) \mathrm{I}_{2}\right] \mathbf{1 2 0}$ as the precatalyst, along with $10 \mathrm{~mol} \%$ of $\mathrm{AgSbF}_{6}$ and $10 \mathrm{~mol} \% \mathrm{AgOPiv}$ as the additives (Scheme 46a). As isocyanates are frequently generated in situ from acyl azides by a Curtius rearrangement, the aminocarbonylation with acyl azides $\mathbf{1 1 9}$ as the electrophiles also gave high yields with $\left[\mathrm{Cp} * \mathrm{Co}(\mathrm{CO}) \mathrm{I}_{2}\right] \mathbf{1 2 0}$ as the precatalyst (Scheme $\left.46 \mathrm{~b}\right)$. 
a)

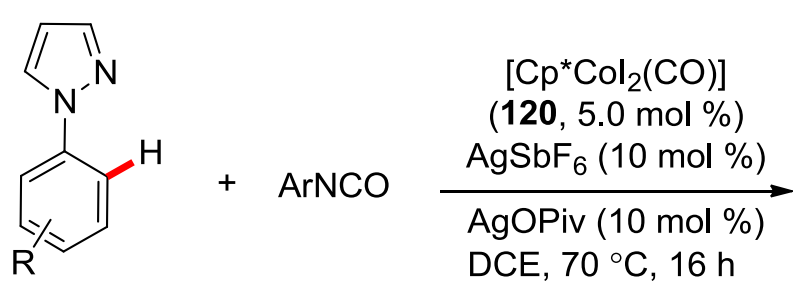

31

130

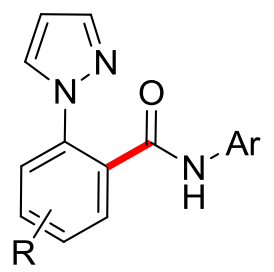

131

b)

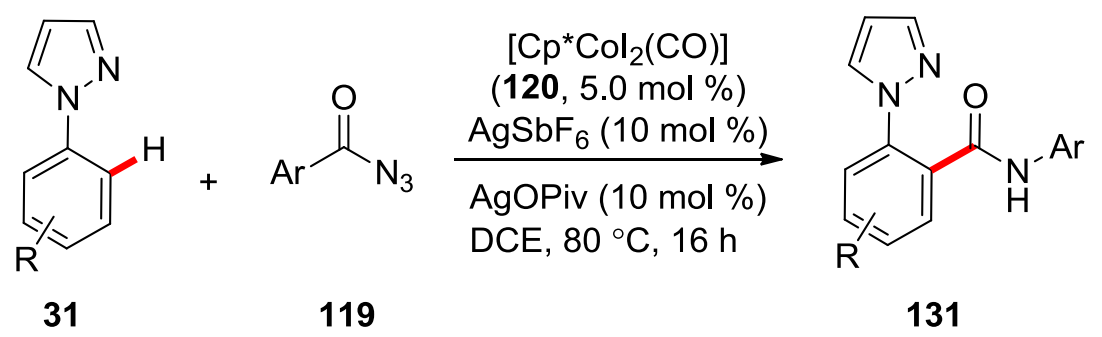

Scheme 46. Cobalt-catalyzed C-H aminocarbonylations of aryl pyrazole 31 . 


\section{Objectives}

Substituted arylacetamide moieties are found in many biologically active compounds, drugs and agrochemicals. ${ }^{[91]}$ Ruthenium-catalyzed ortho-selective functionalizations of substituted benzamides via five-membered metallacycles have been reported. ${ }^{[92,40]}$ In contrast, contributions on ortho-selective functionalizations of weakly coordinating arylacetamides via six-membered metallacycles continue to be limited. ${ }^{[93]}$ There is no report on ruthenium-catalyzed $\mathrm{C}-\mathrm{H}$ functionalizations of substituted arylacetamides. Within our program on cost-effective $\mathrm{C}-\mathrm{H}$ activation, we herein developed uniquely effective oxidative $\mathrm{C}-\mathrm{H}$ alkenylations of weakly coordinating acetamides $\mathbf{1 3 2}$.

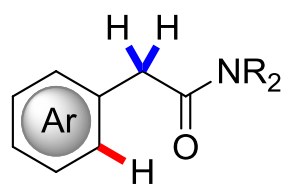

132

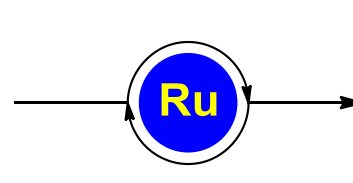

\section{Ru}

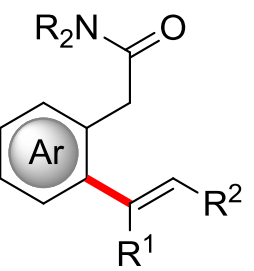

133

Scheme 47. Ruthenium-catalyzed C-H alkenylation of arylacetamides $\mathbf{1 3 2}$.

While arenes bearing weakly coordinating directing groups, such as amides, ${ }^{[94]}$ esters, ${ }^{[64]}$ ketones,${ }^{[61 \mathrm{~b}]}$ or aldehydes ${ }^{[65]}$ were efficiently converted into the corresponding phenol derivatives, $\mathrm{C}-\mathrm{H}$ oxygenation of distal weakly coordinating acetamides or esters via unfavorable six-membered metallacycles have unfortunately proven thus far elusive. Within our research program on ruthenium(II)-catalyzed $\mathrm{C}-\mathrm{H}$ alkenylation of arylacetamides, we developed a ruthenium-catalyzed $\mathrm{C}-\mathrm{H}$ oxygenation of weakly coordinating acetamides $\mathbf{1 3 2}$ and phenylacetyl esters 134.

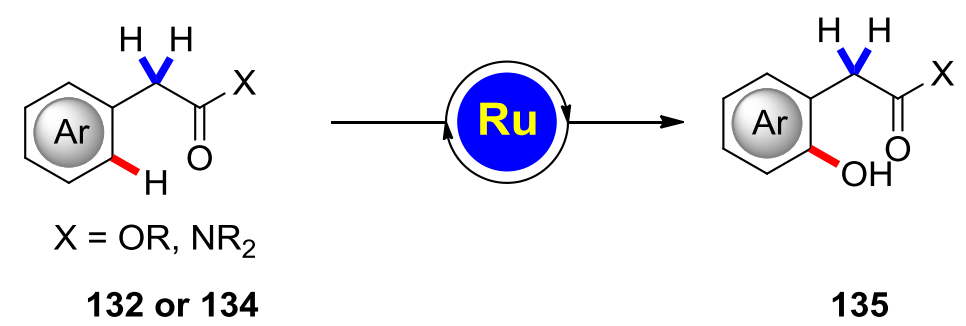

Scheme 48. Ruthenium(II)-catalyzed C-H oxygenation of acetamides 132 and esters 134. 
Organosilicon compounds are useful and ubiquitous synthetic reagents in modern organic chemistry. Among these arylsiloxanes are of particular interest due to their low toxicity and safe handling. ${ }^{[95]}$ Although noble transition metals, such as palladium, ${ }^{[96]}$ rhodium, ${ }^{[97]}$ nickel, ${ }^{[98]}$ iridium ${ }^{[99]}$ and ruthenium $^{[100]}$ have previously been used in $\mathrm{C}-\mathrm{H}$ arylation reactions with arylsilanes as the arylating reagents, cobalt(II)-catalyzed $\mathrm{C}-\mathrm{H}$ arylation reactions of arylsiloxanes have not been explored yet. Therefore, we report herein a new cobalt-based catalytic system for the direct $\mathrm{C}-\mathrm{H}$ arylation of various benzamides 9 using organosilanes 136 .

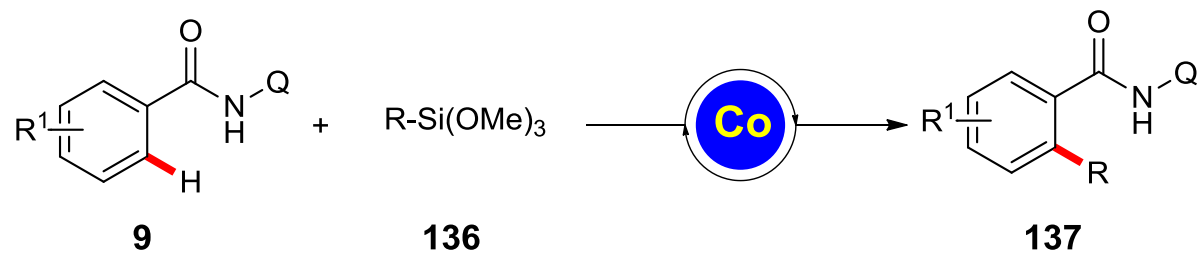

Scheme 49. Cobalt-catalyzed C-H arylation of benzamides 9 with organosilanes 136.

In the past few years, high-valent $\mathrm{Cp}^{*} \mathrm{Co}^{\mathrm{III}}$-derivatives have been identified as increasingly viable tools for the site-selective functionalization of unactivated $\mathrm{C}-\mathrm{H}$ bonds, yet almost exclusively leading to hydroarylations, ${ }^{[79,101]}$ allylations ${ }^{[77,89]}$ or alkynylations. ${ }^{[102]}$ In spite of undisputed advances, cobalt(III)-catalyzed $\mathrm{C}-\mathrm{H} / \mathrm{C}-\mathrm{C}$ activations remain highly challenging. In this regard, we developed a cobalt-catalyzed $\mathrm{C}-\mathrm{H} / \mathrm{C}-\mathrm{C}$ activation of heteroarenes with vinylcyclopropanes $\mathbf{1 3 8}$, for which we performed detailed mechanistic studies also.

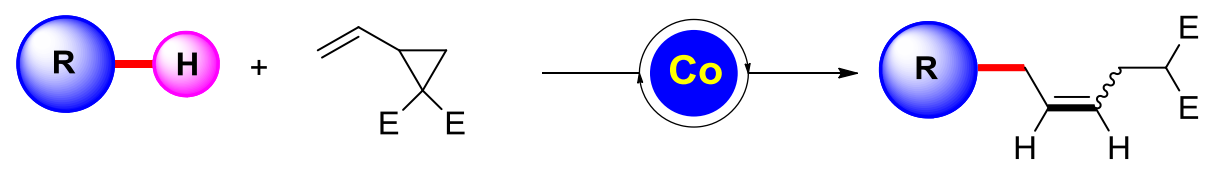

138

Scheme 50. Cobalt(III)-catalyzed $\mathrm{C}-\mathrm{H} / \mathrm{C}-\mathrm{C}$ functionalization. 


\section{Results and Discussion}

\subsection{Distal Weak Coordination of Acetamides in Ruthenium(II)-Catalyzed C-H Activation}

Substituted acetamides are key structural motifs in a plethora of bioactive compounds, drugs, and crop protection agents (Figure 3). ${ }^{[91 \mathrm{c}, 103]} \mathrm{C}-\mathrm{H}$ activation reactions of distal weakly coordinating acetamides via unfavorable six-membered metallacycles continue to be scarce. ${ }^{[91 a, 104]}$ For less expensive ruthenium catalysis, ${ }^{[7 \mathrm{c}, 105]} \mathrm{C}-\mathrm{H}$ functionalizations of challenging arylacetamides have thus far remained elusive. Thus, we wanted to explore an efficient $\mathrm{C}-\mathrm{H}$ activation of challenging arylacetamides by ruthenium(II) catalysis.<smiles>CC(C)NCC(O)COc1ccc(CC(N)=O)cc1</smiles><smiles>[M]C(NC(=O)Cc1ccc(C(=O)O)c(OCC)c1)c1ccccc1N1CCCCC1</smiles>

repaglinide (antidiabetic)

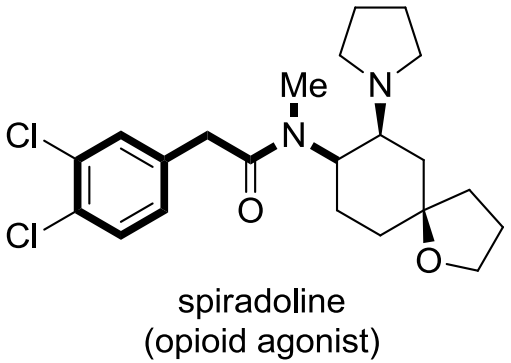<smiles>NC(=O)Cc1cccc2ccccc12</smiles>

naphthaleneacetamide (synthetic auxin)

Figure 3. Selected bioactive compounds featuring arylacetamides.

\subsubsection{Optimization Studies}

Based on the optimized reaction conditions for the ruthenium-catalyzed $\mathrm{C}-\mathrm{H}$ alkenylation of secondary arylacetamide 132i developed by my colleague Dr. Vladislav Kotek, various reaction parameters for the envisioned oxidative $\mathrm{C}-\mathrm{H}$ olefination of challenging primary arylacetamide 132a 
were explored (Table 1). The results showed that the reaction was most efficient with $\mathrm{AgSbF}_{6}$ as the additive and $\mathrm{Cu}(\mathrm{OAc})_{2} \cdot \mathrm{H}_{2} \mathrm{O}$ as the oxidant at $110^{\circ} \mathrm{C}$ for $24 \mathrm{~h}$, giving the desired product 133aa in $64 \%$ yield (entry 13). A significant solvent effect was also observed and the best yields were obtained in 1,4-dioxane (entries 1-7). Other oxidants, such as $\mathrm{Ag}_{2} \mathrm{CO}_{3}, \mathrm{~V}_{2} \mathrm{O}_{5}$ or $\mathrm{MnO}_{2}$, were not effective and only gave the product 133aa in low yields (entries 10-12). We found that the same yield was obtained using $\mathrm{Cu}(\mathrm{OAc})_{2} \cdot \mathrm{H}_{2} \mathrm{O}$ instead of $\mathrm{Cu}(\mathrm{OAc})_{2}$ (entries 2, 13). The use of $\mathrm{AgBF}_{4}$ or $\mathrm{AgSO}_{3} \mathrm{CF}_{3}$ instead of $\mathrm{AgSbF}_{6}$ resulted in decreased yields (entries 13-15). The crucial importance of the additive and ruthenium catalyst was verified through control experiment (entries 8 and 18).

Table 1. Development of oxidative $\mathrm{C}-\mathrm{H}$ alkenylation of acetamide 132a. ${ }^{a}$<smiles>C=CC(=O)OCCCC</smiles>

$132 a$

$5 a$

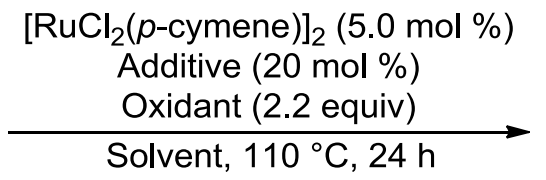<smiles>CCOC(=O)/C=C/c1ccccc1CC(N)=O</smiles>

133aa

\begin{tabular}{|c|c|c|c|c|}
\hline Entry & Solvent & Additive & Oxidant & Yield $(\%)^{b}$ \\
\hline 1 & THF & $\mathrm{AgSbF}_{6}$ & $\mathrm{Cu}(\mathrm{OAc})_{2}$ & $48 \%$ \\
\hline 2 & 1,4-dioxane & $\mathrm{AgSbF}_{6}$ & $\mathrm{Cu}(\mathrm{OAc})_{2}$ & $64 \%$ \\
\hline 3 & toluene & $\mathrm{AgSbF}_{6}$ & $\mathrm{Cu}(\mathrm{OAc})_{2}$ & $<5 \%$ \\
\hline 4 & $\mathrm{H}_{2} \mathrm{O}$ & $\mathrm{AgSbF}_{6}$ & $\mathrm{Cu}(\mathrm{OAc})_{2}$ & -- \\
\hline 5 & $\mathrm{MeOH}$ & $\mathrm{AgSbF}_{6}$ & $\mathrm{Cu}(\mathrm{OAc})_{2}$ & $<5 \%$ \\
\hline 6 & $o$-xylene & $\mathrm{AgSbF}_{6}$ & $\mathrm{Cu}(\mathrm{OAc})_{2}$ & $<5 \%$ \\
\hline 7 & DCE & $\mathrm{AgSbF}_{6}$ & $\mathrm{Cu}(\mathrm{OAc})_{2}$ & $48 \%$ \\
\hline 8 & 1,4-dioxane & -- & $\mathrm{Cu}(\mathrm{OAc})_{2}$ & -- \\
\hline 9 & 1,4-dioxane & $\mathrm{AgSbF}_{6}$ & $\mathrm{Cu}(\mathrm{OTf})_{2}$ & -- \\
\hline 10 & 1,4-dioxane & $\mathrm{AgSbF}_{6}$ & $\mathrm{Ag}_{2} \mathrm{CO}_{3}$ & -- \\
\hline 11 & 1,4-dioxane & $\mathrm{AgSbF}_{6}$ & $\mathrm{~V}_{2} \mathrm{O}_{5}$ & -- \\
\hline
\end{tabular}




\begin{tabular}{|c|c|c|c|c|}
\hline 12 & 1,4-dioxane & $\mathrm{AgSbF}_{6}$ & $\mathrm{MnO}_{2}$ & -- \\
\hline Entry & Solvent & Additive & Oxidant & Yield $(\%)^{b}$ \\
\hline 13 & 1,4-dioxane & $\mathrm{AgSbF}_{6}$ & $\mathrm{Cu}(\mathrm{OAc})_{2} \cdot \mathrm{H}_{2} \mathrm{O}$ & $64 \%$ \\
\hline 14 & 1,4-dioxane & $\mathrm{AgBF}_{4}$ & $\mathrm{Cu}(\mathrm{OAc})_{2}$ & $53 \%$ \\
\hline 15 & 1,4-dioxane & $\mathrm{AgSO}_{3} \mathrm{CF}_{3}$ & $\mathrm{Cu}(\mathrm{OAc})_{2}$ & $40 \%$ \\
\hline 16 & 1,4-dioxane & $\mathrm{AgSbF}_{6}$ & $\mathrm{Cu}(\mathrm{OAc})_{2}$ & $42 \%^{c}$ \\
\hline 17 & 1,4-dioxane & $\mathrm{AgSbF}_{6}$ & $\mathrm{Cu}(\mathrm{OAc})_{2}$ & $53 \%{ }^{d}$ \\
\hline 18 & 1,4-dioxane & $\mathrm{AgSbF}_{6}$ & $\mathrm{Cu}(\mathrm{OAc})_{2}$ & $--^{e}$ \\
\hline
\end{tabular}

${ }^{a}$ Reaction conditions: 132a (0.50) mmol, 5a (1.00 mmol), $\left[\mathrm{RuCl}_{2}(p \text {-cymene })\right]_{2}(5.0 \mathrm{~mol} \%)$, additive $(20 \mathrm{~mol} \%)$, oxidant $(1.10 \mathrm{mmol}), 110{ }^{\circ} \mathrm{C}$, solvent $(2.0 \mathrm{~mL})$, reaction time $24 \mathrm{~h} .{ }^{b}$ Yields of isolated products. ${ }^{c} 80{ }^{\circ} \mathrm{C} .{ }^{d} 120{ }^{\circ} \mathrm{C} .{ }^{e}$ Without $\left[\mathrm{RuCl}_{2}(p \text {-cymene })\right]_{2}$.

\subsubsection{Scope of Ruthenium(II)-Catalyzed C-H Alkenylation}

\subsubsection{Scope of Primary Amides}

With the optimized catalytic system in hand, we explored the scope of primary amides-assisted $\mathrm{C}-\mathrm{H}$ alkenylations with diversely decorated substrates 132 (Scheme 51). Pleasingly, a range of substituents at the meta- or para-positions (132b-132f) were tolerated to provide various alkenylated phenylacetamides 133ba-133fa in high yields. Amides containing a napthyl moiety were also effective, providing the desired product 133. Ortho-substitution 132g slowed the reaction somewhat, but acceptable yields could be obtained nonetheless (Scheme 51). Different alkenes, such as methyl acrylate 5c, naphthalen-2-yl acrylate $\mathbf{5 f}$, vinylsulfonylbenzene $\mathbf{5 g}$, performed very well as the alkene reaction partners. Finally, an ortho-alkenylated arylacetamide 133ah containing sensitive cholesteryl moiety was synthesized in moderate yield as well. 
<smiles>[R]OC([R])=CC=CCC(N)=O</smiles>

132

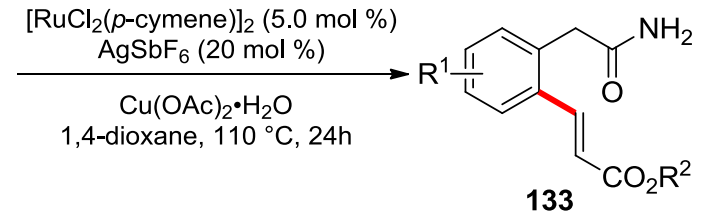<smiles>[R]OC=Cc1ccccc1CC(N)=O</smiles>

$\mathrm{R}=\mathrm{Et}$ (133ab): $\quad 71 \%$

$\mathrm{R}=\mathrm{Ph}$ (133ae): $56 \%$

$\mathrm{R}=n \mathrm{Bu}$ (133aa): 64\%

$\mathrm{R}=4-\mathrm{Cl}$ (133ca): $\quad 66 \%$

$R=\operatorname{Me}(133 c c): 52 \%$
$R=\operatorname{Bn}(133 c d): 64 \%$

$\mathrm{R}=3-\mathrm{Me}$ (133ea): $58 \%$

$\mathrm{R}=3$-OMe (133fa): $51 \%$

$R=2-M e(133 g a): 46 \%$<smiles>NC(=O)Cc1ccccc1/C=C/C(=O)Oc1ccc2ccccc2c1</smiles>

133af: $50 \%$<smiles>CCCCOC(=O)/C=C/c1ccc2ccccc2c1CC(N)=O</smiles>

133ha: $71 \%$<smiles>NC(=O)Cc1ccccc1/C=C/Sc1ccccc1</smiles>

133ag: $61 \%$<smiles>CC(C)CCC[C@H](C)[C@]1(C)CC[C@H]2[C@@H]3CC=C4CC(OC(=O)/C=C/c5ccccc5CC(N)=O)CC[C@]4(C)[C@H]3CC[C@]21C</smiles>

133ah: $57 \%^{a}$

a $120^{\circ} \mathrm{C}, 1,4$-dioxane/toluene $(9: 1)$

Scheme 51. Scope of primary amides group for the ruthenium(II)-catalyzed C-H alkenylation.

\subsubsection{Scope of Secondary and Tertiary amides}

With the optimized reaction condition of $\mathrm{C}-\mathrm{H}$ alkenylation of secondary amide in hand, and together with Dr. Vladislav Kotek, we explored the scope of the olefination with respect to the amide group, which was expected to have a significant effect on the reaction outcome (Scheme 52). For different substitution on the arene, both electron-donating and electron-withdrawing substituents were tolerated. Olefination of bromo-substituted amide 132t was carried out on a gram scale and the 
resulting product 133tc could be easily isolated in very good yields by simple aqueous work-up and recrystallization. Ortho-substitution was also acceptabled and delivered the alkenylated product 133yc in acceptable yield. Naphthalene derived substrate 132x was also viable. The robustness of the ruthenium(II) catalysis was highlighted by racemization-free reaction conditions (133na).<smiles>[R]OC(=O)C=C[NH3+]</smiles>

132<smiles>[R]OC=Cc1ccccc1CC(=O)NC(C)(C)C</smiles>

$\mathrm{R}=\mathrm{Me}(133 \mathrm{ic}): 86 \%^{\mathrm{a}}$ $\mathrm{R}=n \mathrm{Bu}(133 \mathrm{ia}): 84 \%$<smiles>CCCN(C(=O)Cc1ccccc1/C=C/C(C)=O)C(C)CC</smiles>

133mc: $60 \%{ }^{a}$<smiles>[R]OC(=O)C=Cc1cc([R])ccc1CC(=O)NC(C)(C)C</smiles>

$R=F(133 p c): \quad 81 \%$ $\mathrm{R}=\mathrm{OMe}$ (133qc): $\quad 73 \%$ $\mathrm{R}=\mathrm{OAC}(133 \mathrm{rc}): \quad 70 \%^{\mathrm{a}}$ $\mathrm{R}=\mathrm{NHTs}$ (133sc): $66 \%$<smiles>CCCOC(=O)/C=C/c1ccc2ccccc2c1CC(=O)N1CCCC1</smiles>

133xa: $60 \%^{\mathrm{a}}$

5

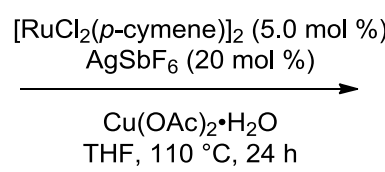<smiles>CCCCNC(=O)Cc1ccccc1/C=C/C(=O)OC</smiles>

133jc: $86 \%^{a}$<smiles>CCCOC(=O)/C=C/c1ccccc1CC(=O)NC(C)c1ccccc1</smiles>

133na: $77 \%$<smiles>[R]OC(=O)C=Cc1ccc([R])cc1CC(=O)NC(C)(C)C</smiles>

$\mathrm{R}=\mathrm{Br}($ 133tc): $\quad 85 \%$ gram-scale: $\quad 83 \%^{a}$ $\mathrm{R}=\mathrm{Ph}$ (133uc): $90 \%^{\mathrm{a}}$ $\mathrm{R}=\operatorname{Me}(133 \mathrm{vc}): \quad 91 \%^{a}$<smiles>CCCOC(=O)/C=C/c1ccccc1CC(=O)NCCCOC(C)=O</smiles>

133oa: $61 \%^{a}$<smiles>CCCOC(=O)C=Cc1cc([N+](=O)[O-])ccc1CC(=O)NC(C)(C)C</smiles>

133wa: $65 \%^{a}$<smiles>CNC(=O)Cc1c(C)cccc1/C=C/COC</smiles>

133yc: $53 \%$<smiles>[R]O[R6](=O)C=Cc1ccccc1CC(=O)N([R])[R]</smiles>

133<smiles>CCCCOC(=O)/C=C/c1ccccc1CC(=O)N1CCCC1</smiles>

133la: $88 \%$

Scheme 52. Scope of secondary and tertiary amides group for the ruthenium(II)-catalyzed C-H alkenylation. 
However, some substrates also turned out to be less compatible with the catalytic conditions (Scheme 53). Thus, challenging directing groups, like 2-phenylacetic acid 134e and ethyl 2-phenylacetate 134d, were unsuccessful under the developed reaction conditions.
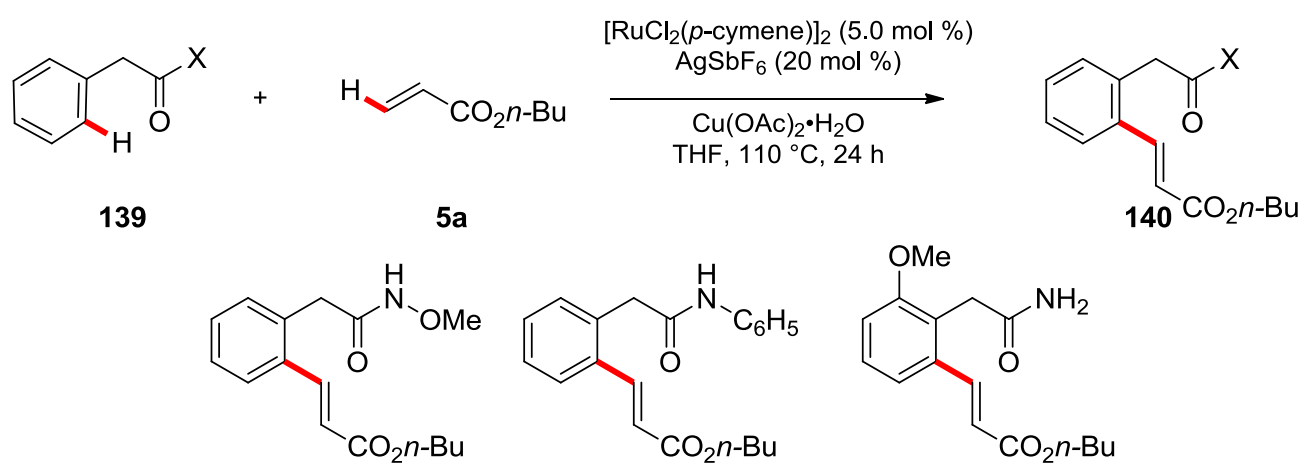

140aa: $0 \%$

140ba: $0 \%$<smiles>COC(=O)/C=C/c1cccc(OC)c1CC(N)=O</smiles>

140ca: $21 \%$<smiles>CCOC(=O)/C=C/c1ccccc1CC(=O)OCC</smiles>

140da: $0 \%$<smiles>CCCOC(=O)/C=C/c1ccccc1CC(=O)O</smiles>

140ea: $0 \%$

Scheme 53. Limitations of the ruthenium(II)-catalyzed C-H alkenylation with different directing groups.

\subsubsection{Weak $O$-Coordination for $\mathrm{C}-\mathrm{H}$ Activation/Alkyne Hydroarylation}

Intrigued by the versatility of the ruthenium(II)-carboxylate catalysis, we became attracted to $\mathrm{C}-\mathrm{H}$ alkenylations through redox-neutral alkyne hydroarylations. By replacing $\mathrm{Cu}(\mathrm{OAc})_{2} \cdot \mathrm{H}_{2} \mathrm{O}$ with $1-\mathrm{AdCO}_{2} \mathrm{H}$, the hydroarylation of alkynes $\mathbf{5 1}$ could be facilitated (Scheme 54). The ruthenium(II)-catalyzed $\mathrm{C}-\mathrm{H}$ hydroarylations of acetamides $\mathbf{1 3 2}$ provided a excellent stereoselectivity in accessing trisubstituted alkenes $\mathbf{1 3 3}$, again with both secondary and challenging primary amides $\mathbf{1 3 2}$, respectively. 


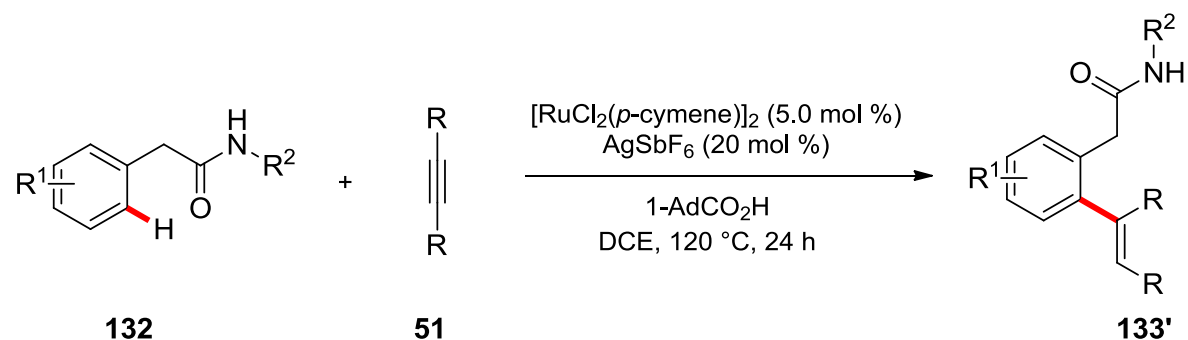<smiles>CC(C)(C)NC(=O)Cc1ccccc1/C=C/c1ccccc1</smiles>

133'ic: $57 \%$<smiles>CC(Br)(Br)NC(=O)Cc1cc(Br)ccc1C(=Cc1ccc(F)cc1)c1ccc(F)cc1</smiles>

133 'td: $61 \%$<smiles>NC(=O)Cc1ccccc1/C(=C/c1ccccc1)c1ccccc1</smiles>

133'ac: $66 \%^{a}$

${ }^{a}\left[\mathrm{RuCl}_{2}(p \text {-cymene })\right]_{2}(10 \mathrm{~mol} \%)$ in 1,4-dioxane.

Scheme 54. Ruthenium(II)-catalyzed hydroarylation of alkynes 51.

\subsubsection{Mechanistic Studies}

\subsubsection{Intermolecular Competition Experiments}

To gain insights into the reaction mechanism, a set of competition experiments was performed. Intermolecular competition experiment between 2-phenylacetamide 132a and 2,2-dimethyl-1-phenylpropan-1-one 58a revealed that although both substrates contain weakly coordinating directing groups, primary amides $\mathbf{1 3 2}$ were found to be even more difficult substrates than ketones $\mathbf{5 8}$ in ruthenium-catalyzed $\mathrm{C}-\mathrm{H}$ functionalizations (Scheme 55).<smiles>NC(=O)Cc1ccccc1</smiles>

$132 \mathrm{a}$

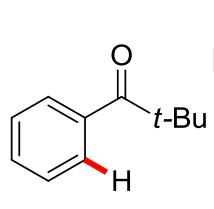

$58 a$<smiles>CCCOC(=O)C=Cc1ccccc1CC(N)=O</smiles>

133aa: $27 \%$<smiles>CCCCC(=O)c1ccccc1C=CCOCC</smiles>

141: $53 \%$

Scheme 55. Intermolecular competition experiment between acetamide 132a and ketone 58a. 
We also performed an intermolecular competition experiment between benzamide 132a and 2-phenylacetamide 9a (Scheme 56). It turned out that almost exclusive functionalization of benzamide 142 was observed. Therefore, it could be concluded that formation of the five-membered ruthenacycle is preferred over formation of the six-membered metallacycle.

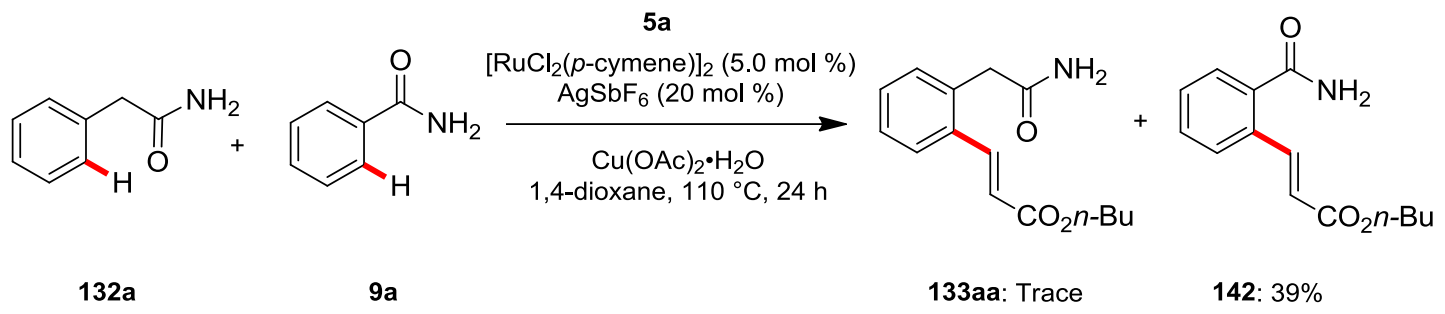

Scheme 56. Competition experiment between benzamide 132a and 2-phenylacetamide 9a.

Additionally, a competition experiment between primary and secondary amides showed that the secondary amide $\mathbf{1 3 2} \mathbf{i}$ is more reactive and revealed that alkyl-subsititution on the amide nitrogen increases the reactivity (Scheme 57).

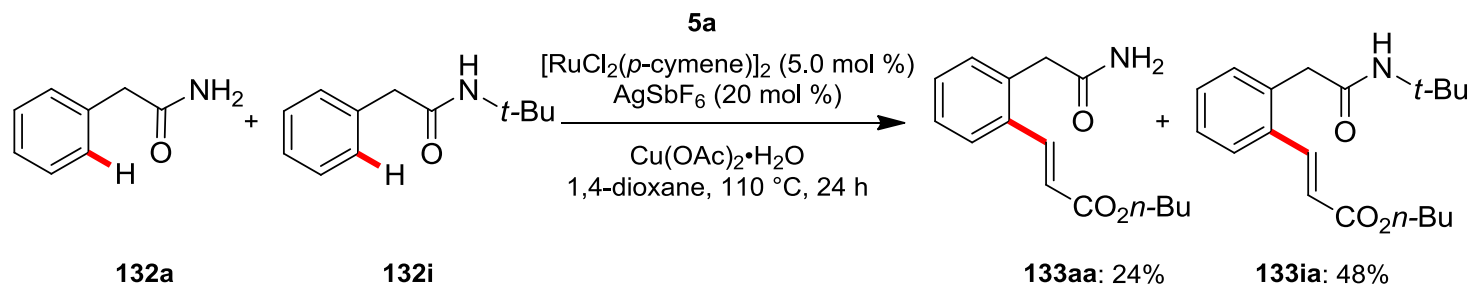

Scheme 57. Competition experiment between primary amide 132a and secondary amide 132i.

A competition experiment between electron-rich substrate 132i and electron-deficient substrate 132d revealed a preferred functionalization of $\mathbf{1 3 2 i}$ (Scheme 58), which is not in agreement with a concerted metalation/deprotonation (CMD) mechanism. Instead, the observations are better rationalized by a base-assisted internal electrophilic-type substitution (BIES) process. 


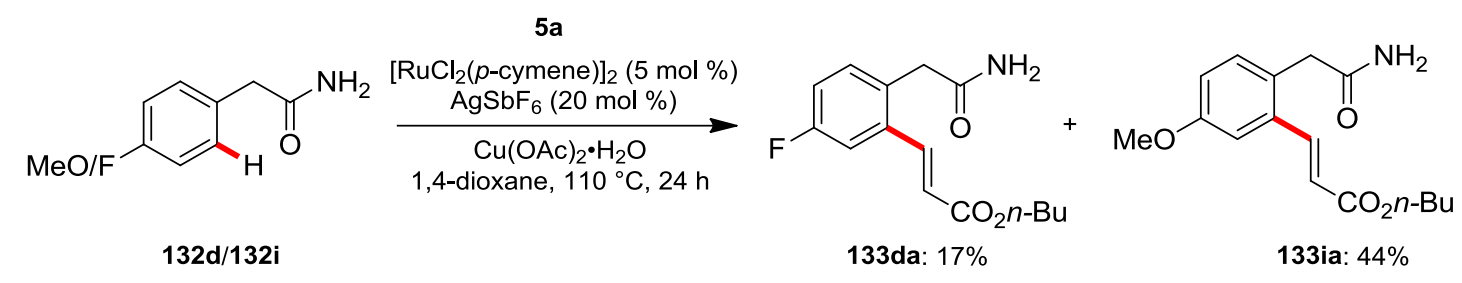

Scheme 58. Competition experiment between electron-rich and electron-deficient amides 132.

\subsubsection{C-H Alkenylation in the Presence of Isotopically Labelled Cosolvent}

To rationalize the $\mathrm{C}-\mathrm{H}$ activation mechanism, the catalytic reaction was carried out in the presence of deuterated cosolvent $\mathrm{CD}_{3} \mathrm{OD}$ under otherwise identical reaction conditions. A significant $\mathrm{H} / \mathrm{D}$ exchange occurring in the ortho-position of the product $[\mathrm{D}]_{n}-\mathbf{1 3 3 q c}$ and reisolated starting material $[\mathrm{D}]_{n} \mathbf{- 1 3 2 q}$ was observed (Scheme 59). The result suggests that the $\mathrm{C}-\mathrm{H}$ metalation is reversible.<smiles>COc1cccc(CC(=O)NC(C)(C)C)c1</smiles>

132q

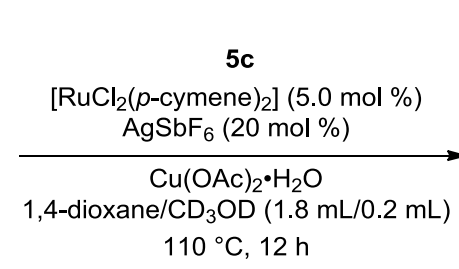
$110^{\circ} \mathrm{C}, 12 \mathrm{~h}$

$[D]_{n}-133 q c: 60 \%$<smiles>[2H]c1cc(OC)cc([18OH])c1CC(=O)NC(C)(C)C</smiles>

$[\mathrm{D}]_{n}-132 \mathrm{q}: 35 \%$

Scheme 59. H/D-exchange study of ruthenium-catalyzed C-H alkenylation.

\subsubsection{Kinetic Isotope Effect}

Kinetic isotope effect (KIE) studies using in situ IR spectroscopy to determine the independent reaction rates of undeuterated substrate $\mathbf{1 3 2} \mathbf{i}$ and deuterated substrate $[\mathrm{D}]_{5} \mathbf{- 1 3 2} \mathbf{i}$, resulted in a minor value of $k_{\mathrm{H}} / k_{\mathrm{D}} \approx 1.0$ (Scheme 60 ). The observed KIE is in good agreement with the results obtained 
from the H/D-exchange experiments, suggesting the reaction to proceed via a reversible cycloruthenation process.

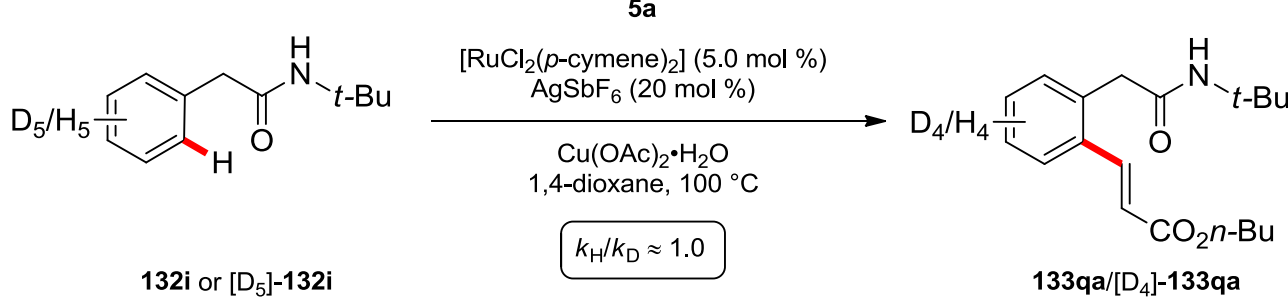

Scheme 60. KIE experiment for the ruthenium-catalyzed C-H alkenylation.

\subsubsection{Proposed Catalytic Cycle}

Based on our experimental studies, a plausible catalytic cycle was proposed (Scheme 61). The active catalytic species is formed by reaction of the ruthenium(II) precursor with silver hexafluoroantimonate. The key six-membered ruthenacycle $\mathbf{1 4 4}$ is then formed by a carboxylate-assisted base-assisted internal electrophilic substitution (BIES) event. Additionally, extensive computational studies by DFT calculations were performed by T. Rogge. Comparison between the corresponding five-membered analogue 144' with the six-membered ruthenacycle 144, found that 144 is destabilized by $6.9 \mathrm{kcal} \mathrm{mol}^{-1}$, while the deprotonative transition state is $2.8 \mathrm{kcal}$ $\mathrm{mol}^{-1}$ higher in energy. Therefore, these results show again that the $\mathrm{C}-\mathrm{H}$ activation of arylacetamides is more challenging. Accordingly, a coordination of acrylate 5a leads to intermediate 145, in which a migratory insertion of the coordinated acrylate $\mathbf{5 a}$ into the carbon-ruthenium bond delivers eight-membered ruthenacycle 146. Finally, ruthenacycle 146 undergoes $\beta$-hydride elimination to form alkene-coordinated complex 143. 

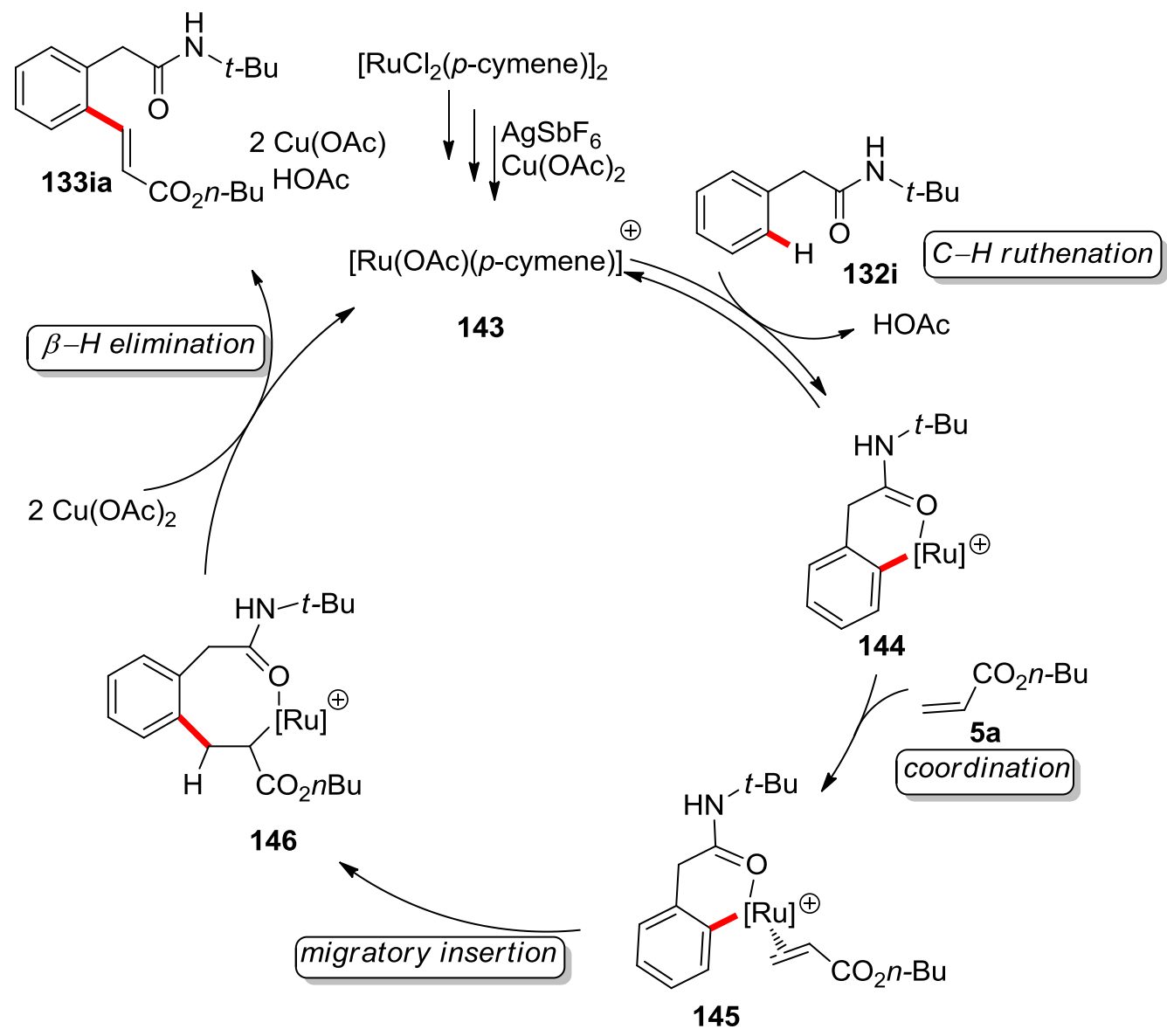

Scheme 61. Plausible catalytic cycle for ruthenium-catalyzed C-H alkenylation. 


\subsection{Ruthenium(II)-Catalyzed C-H Oxygenation of Weakly-Coordinating}

The catalytic direct oxygenation of arene $\mathrm{C}\left(\mathrm{sp}^{2}\right)-\mathrm{H}$ bonds represents the most step-economical approach to substituted phenols. ${ }^{[106]}$ Although significant advances have been accomplished, many challenges remain. To date, most research have been focused on metals such as palladium ${ }^{[107]}$ and copper. ${ }^{[108]}$ In contrast, ruthenium was rarely reported in $\mathrm{C}-\mathrm{H}$ oxygenation reaction. Such kind of transformation was accomplished with versatile ruthenium(II) catalysts. ${ }^{[7 \mathrm{c}, 18 \mathrm{c}]}$ Arenes bearing weakly coordinating directing groups, such as amides, ${ }^{[94]}$ esters, ${ }^{[64]}$ ketones, ${ }^{[61 b]}$ or aldehydes, ${ }^{[65]}$ were efficiently converted into the corresponding phenol derivatives via five-membered metallacycles. While $\mathrm{C}-\mathrm{H}$ oxygenation with distal weakly coordinating acetamides via unfavorable six-membered metallacycles have unfortunately thus far prove elusive. ${ }^{[93 a, 104 b]}$ Based on the former results of ruthenium(II)-catalyzed $\mathrm{C}-\mathrm{H}$ activations of weakly $\mathrm{O}$-coordinating arylacetamides performed by our group ${ }^{[109]}$ we herein present the unique $\mathrm{C}-\mathrm{H}$ oxygenation of weakly coordinating acetamides.

\subsubsection{Optimization Studies for Ruthenium(II)-Catalyzed C-H Oxygenation}

We commenced our studies by probing various oxidants and solvents for the envisioned oxygenation of $N$-(tert-butyl)-2-phenylacetamide 132i (Table 2). At the outset, experiments identified hypervalent iodine(III) reagents as the oxidants of choice, the transformation failed to proceed in 1,4-dioxane in the presence of a ruthenium complex and an oxidant (entry 1). DCE was found to be the solvent of choice, whereas $\mathrm{PhCl}$, toluene, DMF, $m$-xylene or $\mathrm{CH}_{3} \mathrm{CN}$ gave inferior results (entries 2-6). TFA/TFAA, which acted as a good choice in a previous report of ruthenium-catalyzed $\mathrm{C}-\mathrm{H}$ oxygenations, turned out to be unsuitable for this reaction (entry 7 ). $30 \%$ of benzofuran-2(3H)-one byproduct was observed when using solvent mixure of DCE/TFA (entry 8). Among a set of oxidants, such as $\mathrm{PhI}(\mathrm{TFA})_{2}, \mathrm{~K}_{2} \mathrm{~S}_{2} \mathrm{O}_{8},\left(\mathrm{NH}_{4}\right)_{2} \mathrm{~S}_{2} \mathrm{O}_{4}, \mathrm{Cu}(\mathrm{OAc})_{2}$ and $\mathrm{PhI}(\mathrm{OAc})_{2}, \mathrm{PhI}(\mathrm{TFA})_{2}$ gave the best results (entries 9-13). We also tried to increase or decrease the reaction temperature, but superior results were obtained at a reaction temperature of $110^{\circ} \mathrm{C}$ (entries 9, 14-16). There was no conversion of the starting material 132i in absence of the $\mathrm{RuCl}_{2}$ (p-cymene) $]_{2}$ catalyst (entry 17). At last, we found that $5.0 \mathrm{~mol} \%$ of $\left[\mathrm{RuCl}_{2}(p \text {-cymene) }]_{2}\right.$ was best effective to promote the desired reaction (entry 18$)$. 
Table 2. Development of oxidative C-H oxygenation of acetamide $132 \mathbf{i}^{a}{ }^{a}$

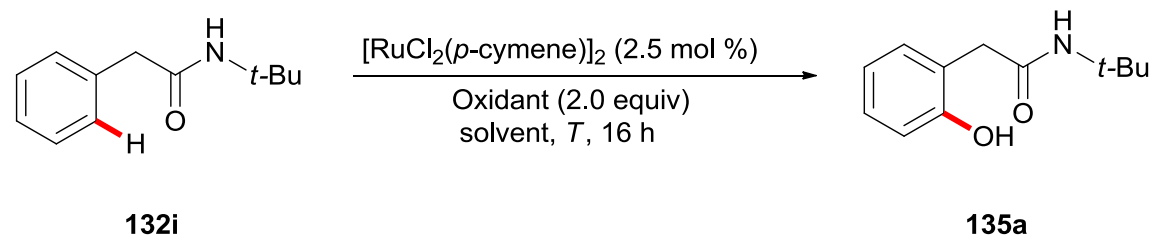

\begin{tabular}{|c|c|c|c|c|}
\hline Entry & Oxidant & Solvent & $T\left({ }^{\circ} \mathrm{C}\right)$ & Yield \\
\hline 1 & $\mathrm{PhI}(\mathrm{TFA})_{2}$ & 1,4-dioxane & 110 & NR \\
\hline 2 & $\mathrm{PhI}(\mathrm{TFA})_{2}$ & $\mathrm{PhCl}$ & 110 & $10 \%$ \\
\hline 3 & $\operatorname{PhI}(\mathrm{TFA})_{2}$ & toluene & 110 & $16 \%$ \\
\hline 4 & $\operatorname{PhI}(\mathrm{TFA})_{2}$ & $\mathrm{DMF}$ & 110 & NR \\
\hline 5 & $\operatorname{PhI}(\mathrm{TFA})_{2}$ & $m$-xylene & 110 & $15 \%$ \\
\hline 6 & $\mathrm{PhI}(\mathrm{TFA})_{2}$ & $\mathrm{CH}_{3} \mathrm{CN}$ & 110 & ND \\
\hline 7 & $\mathrm{PhI}(\mathrm{TFA})_{2}$ & TFA/TFAA $(3: 1)$ & 110 & ND \\
\hline 8 & $\operatorname{PhI}(\mathrm{TFA})_{2}$ & DCE/TFA (4:1) & 110 & $30 \%^{b}$ \\
\hline 9 & $\operatorname{PhI}(\mathrm{TFA})_{2}$ & DCE & 110 & $54 \%$ \\
\hline 10 & $\mathrm{~K}_{2} \mathrm{~S}_{2} \mathrm{O}_{8}$ & DCE & 100 & NR \\
\hline 11 & $\left(\mathrm{NH}_{4}\right)_{2} \mathrm{~S}_{2} \mathrm{O}_{4}$ & DCE & 100 & NR \\
\hline 12 & $\mathrm{Cu}(\mathrm{OAc})_{2}$ & DCE & 100 & NR \\
\hline 13 & $\mathrm{PhI}(\mathrm{OAc})_{2}$ & DCE & 100 & $25 \%$ \\
\hline 14 & $\mathrm{PhI}(\mathrm{TFA})_{2}$ & DCE & 120 & $51 \%$ \\
\hline 15 & $\mathrm{PhI}(\mathrm{TFA})_{2}$ & DCE & 80 & $35 \%$ \\
\hline 16 & $\operatorname{PhI}(\mathrm{TFA})_{2}$ & DCE & $\mathrm{rt}$ & NR \\
\hline 17 & $\mathrm{PhI}(\mathrm{TFA})_{2}$ & DCE & 110 & $\mathrm{NR}^{c}$ \\
\hline 18 & $\mathrm{PhI}(\mathrm{TFA})_{2}$ & DCE & 100 & $62 \%^{d}$ \\
\hline
\end{tabular}

${ }^{a}$ Reaction conditions: 132i $(0.50) \mathrm{mmol}$, oxidant (1.00 mmol), $\left[\mathrm{RuCl}_{2}(p \text {-cymene) }]_{2}(2.5 \mathrm{~mol} \%)\right.$, solvent $(2.0 \mathrm{~mL})$, reaction time $16 \mathrm{~h} .{ }^{b}$ Yields of isolated products. ${ }^{c}$ without $\left[\mathrm{RuCl}_{2}(p \text {-cymene })\right]_{2} \cdot{ }^{d} 5$ mol \% of $\left[\mathrm{RuCl}_{2}(p \text {-cymene })\right]_{2}$. 


\subsubsection{Scope of Acetamides in Ruthenium(II)-Catalyzed C-H Oxygenation}

Having optimized the reaction condition, we next set out to explore the scope of the $\mathrm{C}-\mathrm{H}$ oxygenation reaction. As displayed in Scheme 62, a variety of phenylacetamides 132 were smoothly transformed into the corresponding monohydroxylated products 135 in good yields. The reaction yields roughly correlated with the basicity of the amines incorporated in the amide moiety, and good yields were obtained with secondary amides. The ortho-, meta-, and para-substituted aryl group, as well as electron-withdrawing and electron-donating functional group such as halides and nitro were tolerated. Especially the substrates with eletro-withdrawing group gave the higher yields, such as fluoro and nitro (132p and 132w). meta-bromo-substituted substarte 132t gave the corresponding compound 135ta as the sole product with good regioselectivity. The sterically hindered ortho-bromo substituted acetamide 132 'a was converted to the desired product $\mathbf{1 3 5}$ 'aa in moderate yield. Next, we continued to test the feasibility of employing phenylacetyl esters as directing groups in this $\mathrm{C}-\mathrm{H}$ transformation. We were pleased to find that less reactive phenylacetyl esters were also suitable for this challenging transformation.
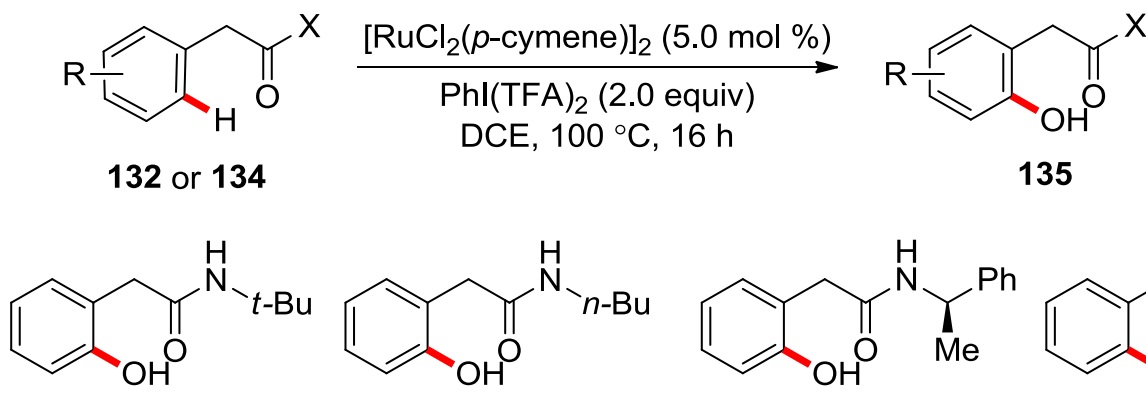<smiles>CC(=O)OCCCNC(=O)Cc1ccccc1O</smiles>

135ia: $62 \%$<smiles>[R][C]C(C)(C)NC(=O)Cc1ccccc1O</smiles>

135ja: $71 \%$

135na: $63 \%$ 135oa: $64 \%$<smiles>CC(C)(C)NC(=O)Cc1c(O)cccc1Br</smiles><smiles>[R]OC(=O)Cc1ccccc1O</smiles>

$\mathrm{R}=4-\mathrm{Me} \mathrm{(135za):} \quad 51 \%$

135'aa: $58 \%$

$R=$ Me (135aa): $52 \%$

$\mathrm{R}=3-\mathrm{Ph}$ (135ua): $\quad 53 \%$

$\mathrm{R}=\mathrm{Et}(135 \mathrm{ba}): \quad 50 \%$

$\mathrm{R}=4-\mathrm{F}$ (135pa): $\quad 63 \%$

$\mathrm{R}=3-\mathrm{Br}(135 \mathrm{ta}): \quad 76 \%$

$\mathrm{R}=4-\mathrm{OAc}$ (135ra): $48 \%$

$\mathrm{R}=4-\mathrm{NO}_{2}(135 \mathrm{wa}): \quad 65 \%$

Scheme 62. Scope of the ruthenium(II)-catalyzed C-H oxygenation. 


\subsection{Low-Valent Cobalt-Catalyzed C-H Arylation}

Biaryl motifs are an important class of building blocks in medicinal chemistry and biochemistry, leading to a great interest in the development of novel and efficient methods to asseable biaryl compounds. ${ }^{[110]}$ Among the available methods, the formation of $\mathrm{C}-\mathrm{C}$ bonds between two substrates by transition metal-catalyzed functionalization of $\mathrm{C}-\mathrm{H}$ bonds presents the advantages of less synthetic steps and an overall high atom economy. ${ }^{[111]}$ Hiyama cross-couplings have proven to be among the most powerful and reliable ways for $\mathrm{C}-\mathrm{C}$ bond formation reactions in organic synthesis. Meanwhile, direct arylation of aromatic $\mathrm{C}-\mathrm{H}$ bonds has received much attention as a potentially more efficient and complementary approach to the conventional cross-coupling methodology. ${ }^{[13 \mathrm{~b}, 112]}$ In 2007, the direct arylation of acetanilide with organosilanes was reported. ${ }^{[13]}$ Subsequently, significant progress has been achieved using organosilanes as coupling partners in the transition-metal-catalyzed $\mathrm{C}-\mathrm{H}$ arylations, with pioneering work demonstrating the utility of direct Hiyama $\mathrm{C}-\mathrm{H}$ arylation based on palladium, ${ }^{[96 a,}{ }^{114]}$ nickel, ${ }^{[98]}$ rhodium, ${ }^{[97,}{ }^{115]}$ iridium ${ }^{[99]}$ and ruthenium $^{[100]}$ catalysis. However, the use of organosilanes as viable cross-coupling partners in cobalt-catalyzed $\mathrm{C}-\mathrm{H}$ functionalization remains unknown. Herein, we report the first cobalt-catalyzed the direct $\mathrm{C}-\mathrm{H}$ arylation of benzamides with organosilanes, which notably avoids the use of stoichiometric amounts of Grignard reagents. ${ }^{[66 \mathrm{~b}, 76,116]}$

\subsubsection{Optimization Studies}

We began our studies by the treatment of benzamide derivative 9a and trimethoxyphenylsilane 136a with $20 \mathrm{~mol} \%$ of $\mathrm{Co}(\mathrm{OAc})_{2}, 3.0$ equivalents of $\mathrm{CsF}$ and 2.0 equivalents of $\mathrm{CuF}_{2}$ in $\mathrm{DMSO}$ at $120{ }^{\circ} \mathrm{C}$ (Table 3, entry 1). The desired arylation product 137aa was formed in $20 \%$ yield. Encouraged by this promising result, a variety of solvents were probed (entries 2-9), and NMP was found to be the reaction medium of choice with a yield of $65 \%$ (entry 8). It is worth noting that a moderate yield was obtained when the reaction was performed in green biomass-derived $\gamma$-valerolactone (GVL) (entry 7), showing the potential of the use of such green solvents in arylation reactions. Next, we investigated the effect of several oxidants in this reaction. The desired product 137aa was obtained in $36 \%$ yield in the presence of $\mathrm{Cu}(\mathrm{OAc})_{2}$ (entry 13), while no product was observed when replacing on $\mathrm{CuF}_{2}$ by other oxidants, such as air, $\mathrm{Mn}(\mathrm{OAc})_{2}$ or AgOPiv (entries 14-16). Decreasing the amount of $\mathrm{CuF}_{2}$ to 
1.0 equivalent or less gave inferior results (entries 11-12). To our delight, the desired product 137aa could be isolated in $72 \%$ yield, when decreasing the reaction temperature to $100{ }^{\circ} \mathrm{C}$.

Table 3. Optimization of the cobalt-catalyzed C-H arylation of benzamide $9 \mathbf{a}^{a}$

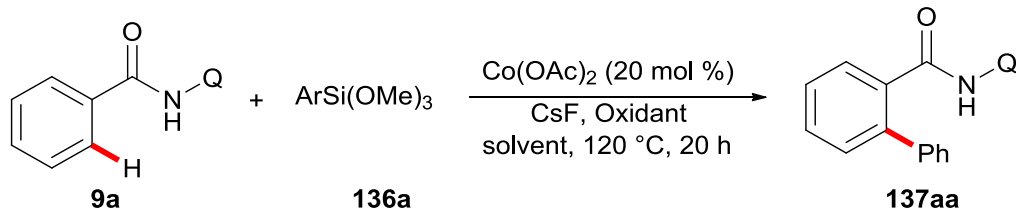

\begin{tabular}{|c|c|c|c|}
\hline Entry & Solvent & Oxidant (equiv) & Isolated yield \\
\hline 1 & DMSO & $\mathrm{CuF}_{2}(2.0)$ & $20 \%$ \\
\hline 2 & DCE & $\mathrm{CuF}_{2}(2.0)$ & $18 \%$ \\
\hline 3 & $\mathrm{DMF}$ & $\mathrm{CuF}_{2}(2.0)$ & $53 \%$ \\
\hline 4 & Toluene & $\mathrm{CuF}_{2}(2.0)$ & - \\
\hline 5 & $\mathrm{THF} / \mathrm{H}_{2} \mathrm{O}$ & $\mathrm{CuF}_{2}(2.0)$ & - \\
\hline 6 & DMA & $\mathrm{CuF}_{2}(2.0)$ & - \\
\hline 7 & GVL & $\mathrm{CuF}_{2}(2.0)$ & $50 \%$ \\
\hline 8 & NMP & $\mathrm{CuF}_{2}(2.0)$ & $65 \%$ \\
\hline 9 & pyridine & $\mathrm{CuF}_{2}(2.0)$ & - \\
\hline 10 & NMP & $\mathrm{CuF}_{2}(2.0)$ & $10 \%^{b}$ \\
\hline 11 & NMP & $\mathrm{CuF}_{2}(1.0)$ & $36 \%$ \\
\hline 12 & NMP & $\mathrm{CuF}_{2}(0.5)$ & $17 \%$ \\
\hline 13 & NMP & $\mathrm{Cu}(\mathrm{OAc})_{2}(2.0)$ & $36 \%$ \\
\hline 14 & NMP & air & - \\
\hline 15 & NMP & $\mathrm{Mn}(\mathrm{OAc})_{2}(2.0)$ & - \\
\hline 16 & NMP & AgOPiv (2.0) & Trace \\
\hline 17 & NMP & $\mathbf{C u F}_{2}(2.0)$ & $72 \%{ }^{c}$ \\
\hline 18 & NMP & $\mathrm{CuF}_{2}(2.0)$ & $71 \%{ }^{d}$ \\
\hline
\end{tabular}

${ }^{a}$ Reaction conditions: 9a $(0.25 \mathrm{mmol}), \mathbf{1 3 6 a}(0.5 \mathrm{mmol}), \mathrm{Co}(\mathrm{OAc})_{2}(20 \mathrm{~mol} \%)$, CsF (3.0 equiv), oxidant (2.0 equiv), solvent $(1.0 \mathrm{~mL})$, under $\mathrm{N}_{2} .{ }^{b}$ without $\mathrm{Co}(\mathrm{OAc})_{2} .{ }^{c} 100{ }^{\circ} \mathrm{C} .{ }^{d} \mathrm{CsF}(1.5$ equiv).

We next examined the effect of the directing groups (Scheme 63). No phenylation took place when $N$-methyl benzamide 9b' was used instead of substrate 9a. Furthermore, the use of $N$-methyl amide 9c' also failed to deliver the phenylation product, indicating that the presence of an NH-motif on the amide nitrogen is required for the reaction to proceed. The reaction appears to be more successful for 
the 8-aminoquinoline motif. Directing groups, such as found in compounds $9 \mathbf{d}^{\prime}, \mathbf{9} \mathbf{e}^{\prime}$ and $\mathbf{9} \mathbf{f}^{\prime}$ which have been extensively used in the transition-metal-catalyzed functionalization of $\mathrm{C}-\mathrm{H}$ bonds, ${ }^{[17]}$ were also ineffective. Therefore, the presence of an $\mathrm{NH}$ bond as well as the strougly-coordinatiy quinoline nitrogen is neccessary for the success of the reaction.

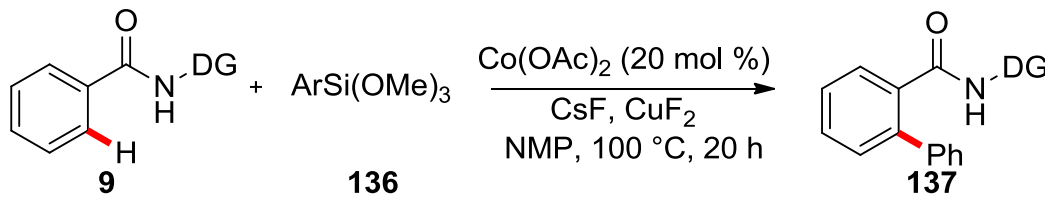<smiles>O=C(Nc1cccc2cccnc12)c1ccccc1</smiles>

137aa: $72 \%$<smiles>Cc1ccc(C(=O)Nc2ccccc2C2=NCCO2)c(P)c1</smiles>

137d'a: $0 \%$<smiles>CNC(=O)c1ccccc1Pc1ccccc1</smiles>

137b'a: $0 \%$<smiles>O=C(NCc1cn(C[Te])nn1)c1ccccc1-c1ccccc1</smiles>

137e'a: $0 \%$<smiles>CN(C(=O)c1ccccc1P)c1cccc2cccnc12</smiles>

137c'a: $0 \%$<smiles>CC(NC(=O)c1cn(CC(=O)O)nn1)c1ccccc1-c1ccccc1</smiles>

137f'a: $0 \%$

Scheme 63. Effect of $N$-substituents on cobalt-catlyzed C-H arylation.

\subsubsection{Scope of Cobalt-Catalyzed C-H Arylation}

\subsubsection{Scope of benzamides}

With the optimized reaction conditions in hand, we explored the scope of the cobalt(II)-catalyzed C$\mathrm{H}$ arylation of arenes 9. As shown in Scheme 64, various benzamide substrates 9 were successfully applied to the $\mathrm{C}-\mathrm{H}$ arylation. Both electron-donating and electron-deficient substituents were tolerated, giving the biaryl products $\mathbf{1 3 7}$ in moderate to high yields. A broad range of functional groups, such as fluoro were compatible with the $\mathrm{C}-\mathrm{H}$ activation. Naphthamide and dimethyl-substituted benzamide $\mathbf{9 h}$ and $9 \mathbf{i}$ were also viable substrates, giving $\mathbf{1 3 7 h a}$ and $137 \mathbf{i a}$ in $60 \%$ and $68 \%$ yield, respectively. 


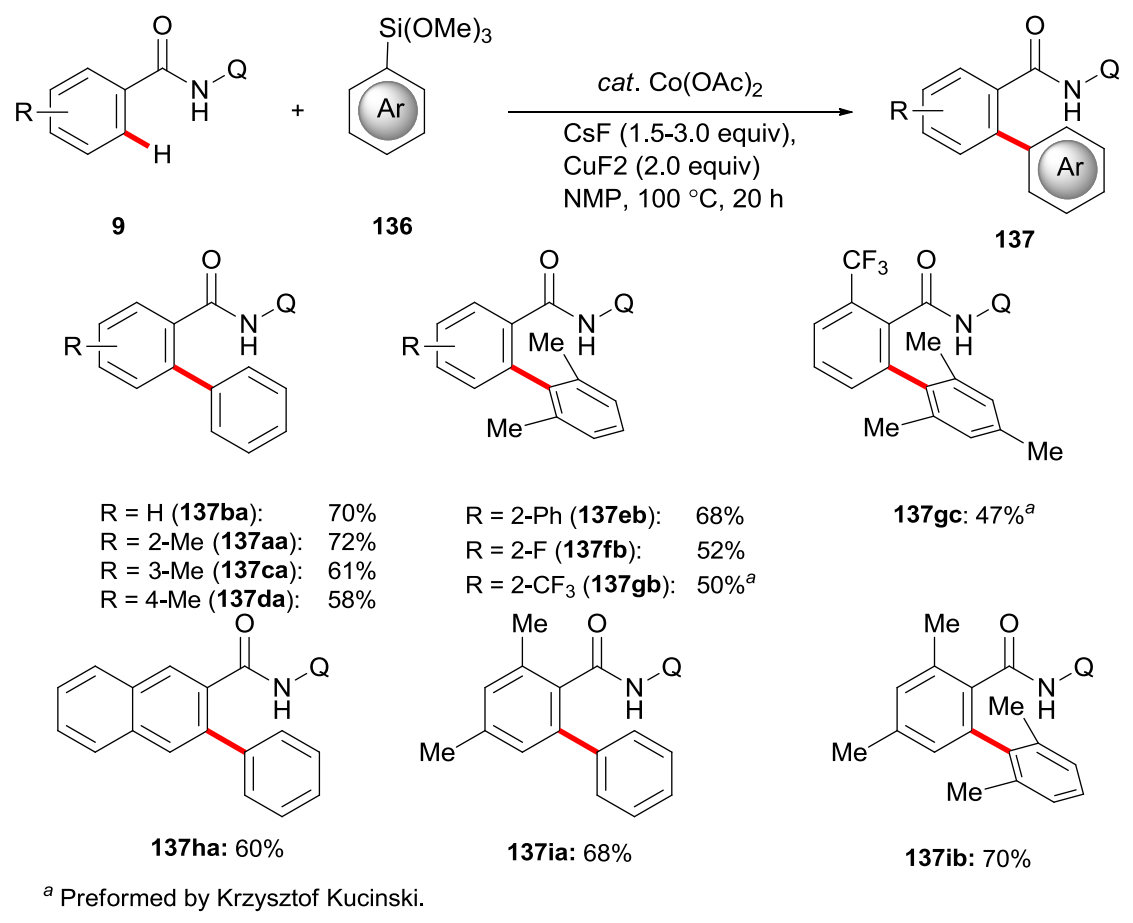

Scheme 64. Scope of cobalt-catalyzed C-H arylation of amides 9.

\subsubsection{Scope of Arylsilanes}

The scope of various organosilanes under the standard reaction conditions was then investigated (Scheme 65). Under the optimized reaction conditions, triethoxyarylsilane gave a lower yield, while trimethylarylsilane was not a viable arylating regent at all. Next, a range of trimthoxyarylsilanes 136 were tested. It is worth noting that triethoxyarylsilanes bearing a methyl group or dimethyl group at the ortho- or diortho- position gave the desired arylated products 137ae and 137ab in $80 \%$ and $62 \%$ yields respectively, showing that the reaction is not sensitive to steric hindrance. It should be noted that ortho- substituted trimthoxyarylsilanes $\mathbf{1 3 6 b}$ gave a higher yield with a lower amount of CsF (137ab). Furthermore, naphthyl organosilane 136j could also participate in the $\mathrm{C}-\mathrm{H}$ arylation, affording the desired product 137aj in $80 \%$ yield. 


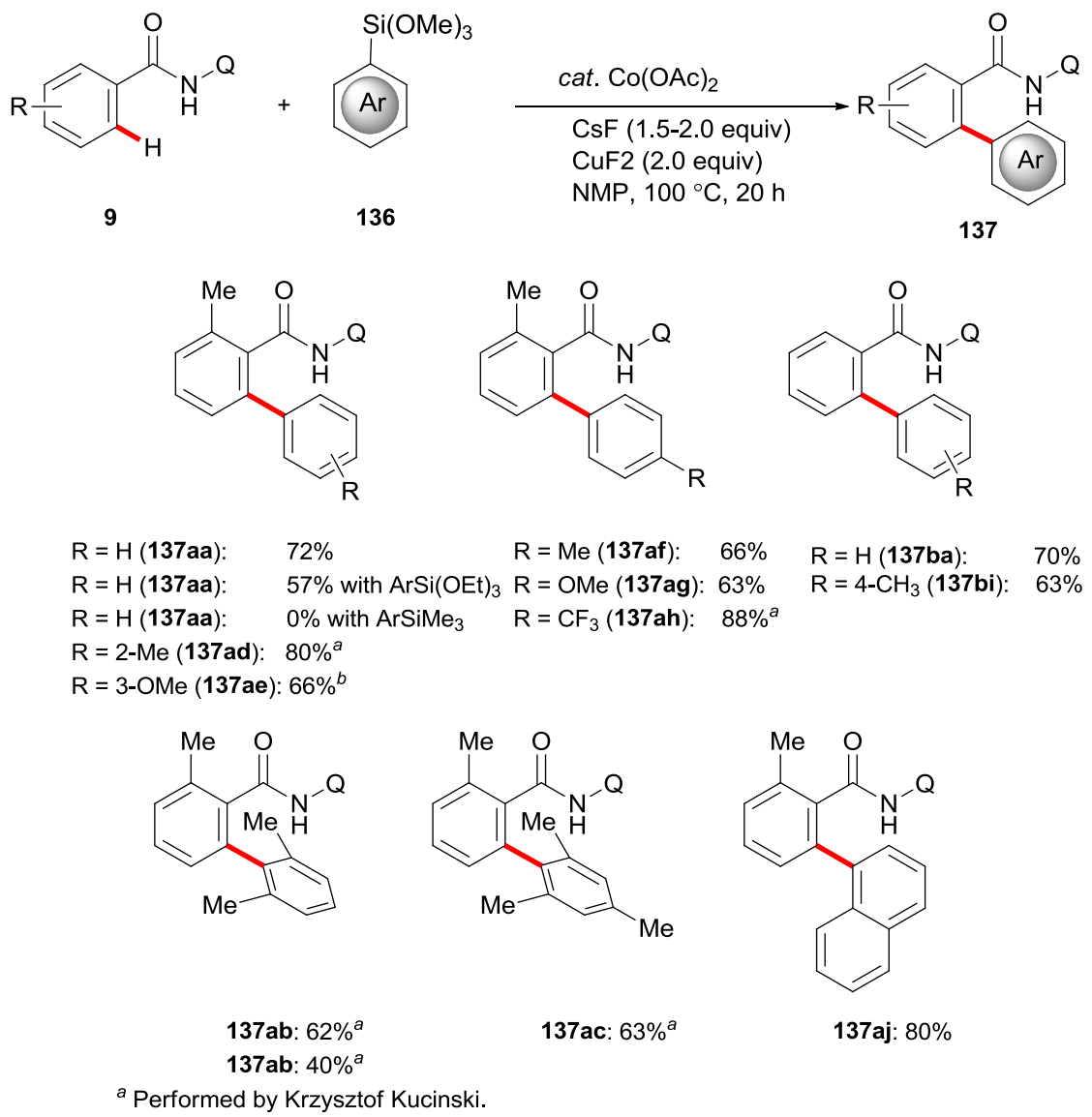

Scheme 65. Scope of cobalt-catalyzed C-H arylation of amides 9 with organosilanes 136.

\subsubsection{Scope of the Cobalt(II)-Catalyzed C-H Arylation of benzamides in GVL}

During the optimization of the reaction conditions, the reaction was found to proceed with a moderate yield when using the biomass-derived solvent GVL. We subsequently became interested to explore the scope of the $\mathrm{C}-\mathrm{H}$ arylation reaction in thid green medium (Scheme 66). Surprisingly, under this reaction conditions, a minor decrease in reactivity was observed, with yields being around 10\%-20\% less than under the optimized reaction conditions, except for naphthyl benzamide $\mathbf{9 h}$. 
<smiles>[H][Y]ONC(=O)C1=C([2H])C=[R]=C=C1</smiles><smiles>CO[SiH2]c1ccccc1</smiles>

136

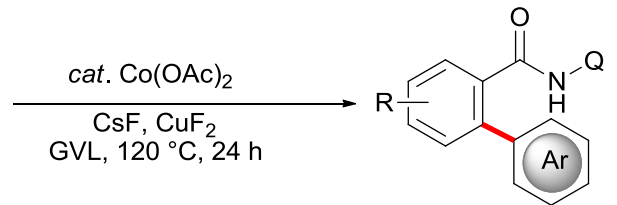

137<smiles>O=C(NO)c1ccccc1-c1ccccc1</smiles>

137ba: $52 \%$<smiles>Cc1cccc(-c2cccc3ccccc23)c1C(=O)NO</smiles>

137aj: $47 \%$<smiles>Cc1cccc(-c2ccccc2)c1C(=O)NO</smiles>

137aa: $50 \%$<smiles>Cc1cc(C)c(C(=O)NO)c(-c2ccccc2)c1</smiles>

137ia: $54 \%$<smiles>O=C(NO)c1cc2ccccc2cc1-c1ccccc1</smiles>

137ha: $63 \%$<smiles>COc1ccc(-c2cccc(C)c2C(=O)NO)cc1</smiles>

137ah: $52 \%$

Scheme 66. Scope of cobalt-catalyzed C-H arylation of amides 9 in biomass-derived GVL.

\subsubsection{Mechanistic Studies - H/D-Exchange Experiment}

In order to gain insights into the reaction mechanism, a catalytic reaction in the presence of deuterated cosolvent $\mathrm{D}_{2} \mathrm{O}$ was carried out under otherwise identical reaction conditions (Scheme 67). The results indicated a significant H/D scrambling in the reisolated starting material $[\mathrm{D}]_{n}-\mathbf{9 d}$ as well as in the product $[\mathrm{D}]_{n}-\mathbf{1 3 7 d a}$. This observation is indicative of a facile $\mathrm{C}-\mathrm{H}$ activation by the cobalt catalyst. 


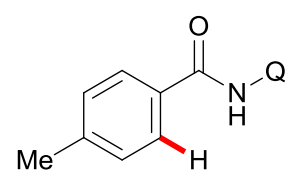

9d

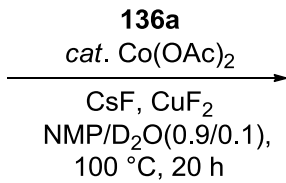

$100{ }^{\circ} \mathrm{C}, 20 \mathrm{~h}$

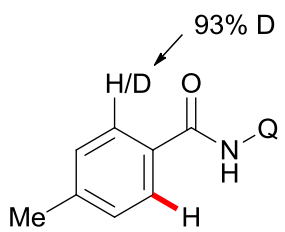

[D] $]^{-9}$ d: $38 \%$

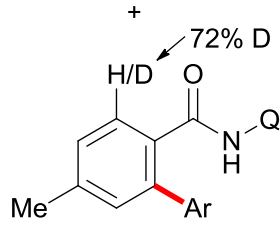

$[D]_{n}-137$ da: $43 \%$

Scheme 67. H/D-exchange study of cobalt-catalyzed C-H arylation.

\subsubsection{Proposed Catalytic Cycle}

Based on the above results, we propose a catalytic cycle to initiate by the formation of the cobalt(III) species 147 by oxidation (Scheme 68). Thereafter, a $\mathrm{C}-\mathrm{H}$ activation step occurs to give the cobalt complex 148. A fluoride-promoted transmetalation ${ }^{[118]}$ then afforded the cobalt(III)-aryl intermediate 149. Subsequent reductive elimination provide the arylated product $\mathbf{1 3 7 b a}$ together with the formation of a cobalt(I) species $\mathbf{1 5 0}$, which is reoxidized to cobalt(III) species by the action of $\mathrm{CuF}_{2}$ to complete the catalytic cycle. 


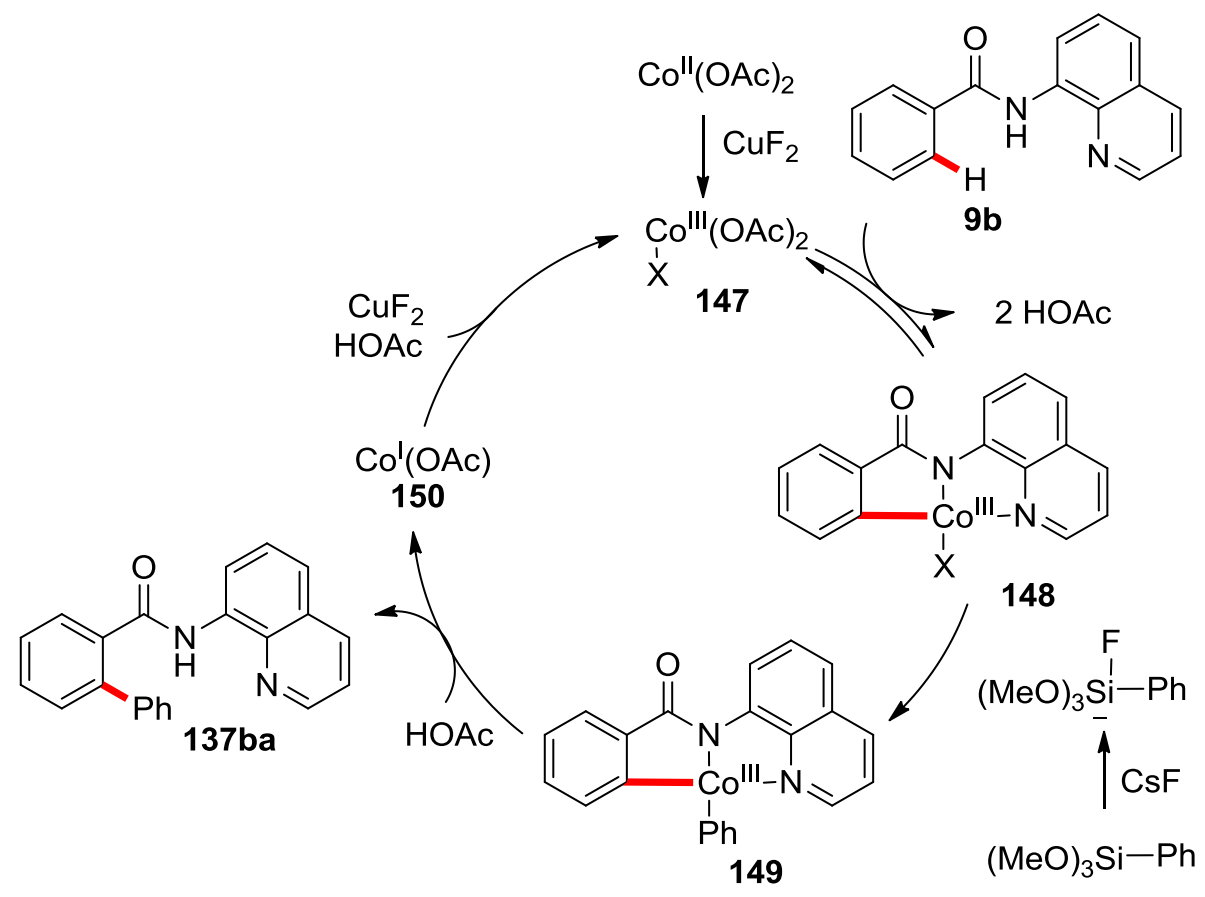

Scheme 68. Plausible catalytic cycle for the cobalt-catalyzed $\mathrm{C}-\mathrm{H}$ arylation. 


\subsection{Cobalt(III)-Catalyzed C-H/C-C Functionalization}

In recent years, the use of naturally abundant $3 \mathrm{~d}$ transition metal catalysts for $\mathrm{C}-\mathrm{H}$ functionalizations has been identified as an increasingly powerful tool for molecular syntheses. ${ }^{[1 \mathrm{a}, 12 a, 119]}$ Particularly, inexpensive cobalt catalysts bear high potential due to the efficient transformations catalyzed by its congeners rhodium and iridium. In early examples, low-valent cobalt catalyzed $\mathrm{C}-\mathrm{H}$ functionalizations generally required a Grignard reagents as the additives. ${ }^{[12 b]}$ More recently, the importance of high-valent $\mathrm{Co}(\mathrm{III})$-catalyzed chelate-assisted $\mathrm{C}-\mathrm{H}$ bond functionalizations has been demonstrated by Ackermann, ${ }^{[102 c, 120]}$ Glorius, ${ }^{[82 b, 89]}$ Ellman, ${ }^{[121]}$ and Chang ${ }^{[122]}$ following early work by Matsunaga and Kanai. ${ }^{[83 a, 123]}$ High-valent $\left[\mathrm{Cp}^{*} \mathrm{Co}^{\mathrm{III}}\right]$ complexes have been applied for the site-selective functionalization of unactivated $\mathrm{C}-\mathrm{H}$ bonds. ${ }^{[85,124]}$

Within our research program on $\left[\mathrm{Cp}^{*} \mathrm{Co}^{\mathrm{III}}\right]$-catalyzed $\mathrm{C}-\mathrm{H}$ functionalizations, ${ }^{[12 \mathrm{a}, 83 \mathrm{~b}]}$ we decided to explore the distinct selectivity features of cobalt(III) catalysis. Therefore, we selected the reaction of indoles with vinylcyclopropanes as a model system to realize $\mathrm{C}-\mathrm{H} / \mathrm{C}-\mathrm{C}$ functionalizations with high selectivity control.

\subsubsection{Optimization Studies}

Optimization studies on the cobalt(III)-catalyzed $\mathrm{C}-\mathrm{H} / \mathrm{C}-\mathrm{C}$ activation are summarized in Table 4. Solvent optimization revealed that DCE was the most efficient reaction medium. When the reaction was conducted in DCE using $\left[\mathrm{Cp} * \mathrm{Co}(\mathrm{CO}) \mathrm{I}_{2}\right]$ as the catalyst and $\mathrm{PivOH}$ as the additive at $50{ }^{\circ} \mathrm{C}$, the desired product 151aa was isolated in $87 \%$ yield (entry 1). Keeping PivOH as the additive, switching the solvent to $\mathrm{MeOH}$ or TFE, the yield of product 151aa significantly decreased. An even lower conversion of the starting material 95a was observed using $\mathrm{H}_{2} \mathrm{O}$ as the solvent (entry 3). Moreover, the additive had a significant impact on the reaction efficiency. Only trace of product 151aa was detected when $\mathrm{Mg}(\mathrm{OPiv})_{2}$ was used. The yield was improved when $10 \mathrm{~mol} \%$ of $\left[\mathrm{Cp} * \mathrm{Co}(\mathrm{CO}) \mathrm{I}_{2}\right]$ and NaOPiv was employed. This reaction was performed by Dr. Daniel Zell during his study on the effect of various acetate and pivalate bases, which resulted in finding that sodium pivalate was the optimal base. Furthermore, different cobalt(III) sources were tested, the results indicated that silver additives are not necessary for the reaction (entry 8) and other ligands are inferior to cyclopentadienyl group (entries 9 and 10).

Notably, all tested reaction conditions exclusively furnished the thermodynamically less favored $Z$ diastereomer in very good selectivities. When treating the substrates with the related $\left[\mathrm{Rh}^{\mathrm{III}} \mathrm{Cp} \mathrm{p}^{*}\right]$ 
catalyst, a mixure of the $E / Z$ diastereomers was obtained with a minor bias for the $E$ diastereomer (entry 11).

Table 4. Optimization study for the $\mathrm{Co}(\mathrm{III})$-catalyzed $\mathrm{C}-\mathrm{H} / \mathrm{C}-\mathrm{C}$ functionalization. ${ }^{a}$

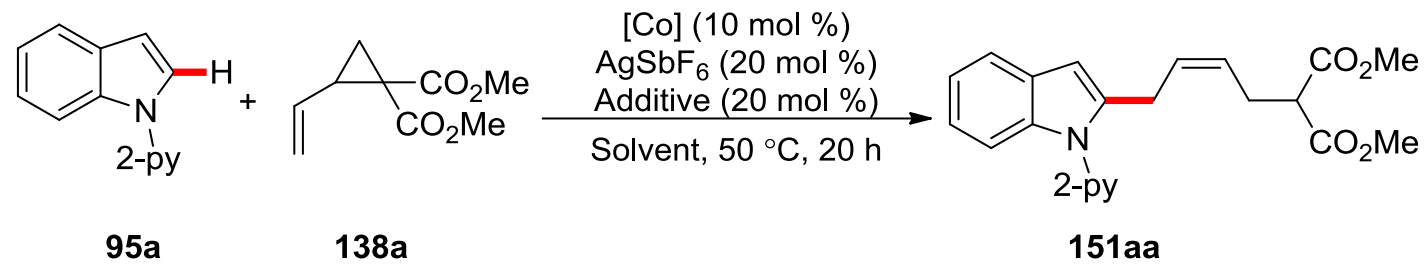

\begin{tabular}{|c|c|c|c|}
\hline Entry & Solvent & Additive & Yield [\%] \\
\hline 1 & DCE & PivOH & 87 \\
\hline 2 & TFE & $\mathrm{PivOH}$ & 45 \\
\hline 3 & $\mathrm{H}_{2} \mathrm{O}$ & $\mathrm{PivOH}$ & 30 \\
\hline 4 & $\mathrm{CH}_{3} \mathrm{OH}$ & $\mathrm{PivOH}$ & 76 \\
\hline 5 & $\mathrm{DCE}$ & $\operatorname{Mg}(\mathrm{OPiv})_{2}$ & $70^{b}$ \\
\hline 6 & DCE & $(t \mathrm{BuCO})_{2} \mathrm{O}$ & 61 \\
\hline 7 & DCE & NaOPiv & $\mathbf{9 3}^{c}$ \\
\hline 8 & DCE & NaOPiv & $77^{d}$ \\
\hline 9 & DCE & NaOPiv & $18^{e}$ \\
\hline 10 & DCE & NaOPiv & $10^{f}$ \\
\hline 11 & DCE & NaOPiv & $77^{g}$ \\
\hline
\end{tabular}

\subsubsection{Scope of the Cobalt(III)-Catalyzed C-H/C-C Functionalization}

With the optimized reaction conditions in hand, the scope of viable indoles 95 and cyclopropanes 133 was examined (Scheme 69). First, substituents in the C5-position of indole 95b were tested, good yields and diastereoselectivities were achieved. Moreover, the utility of this method was further demonstrated by the $5 \mathrm{mmol}$-scale reaction, which provided the corresponding product $\mathbf{1 5 1 a a}$ in $90 \%$ 
yield. A sterically demanding substituent in C3-position was tested, furnishing the desired product 151ca in good yield and excellent $E / Z$ selectivity of 1:25. The observed selectivity is totally different from the one obtained in the rhodium-catalyzed $\mathrm{C}-\mathrm{H} / \mathrm{C}-\mathrm{C}$ bond activation. ${ }^{[125]} \mathrm{A}$ reasonable explanation for this unexpected finding could be the involvement of stabilizing London dispersion interactions, ${ }^{[126]}$ partly exhibited by the pyridyl-ring, which was highlighted by the DFT-calculations performed by Dr. Feldt. ${ }^{[127]}$

Second, various vinylcyclopropane substrates $\mathbf{1 3 8}$ were tested. Vinylcyclopropanes could easily be obtained from the corresponding activated methylene compounds and (E)-1,4-dibromobut-2-ene. ${ }^{[128]}$ Electron-withdrawing groups such as methyl ester and ethyl ester were successfully employed in this reaction, giving the corresponding products in good to excellent yields and good $E / Z$ selectivity ranging from 1:11 to 1:25. In contrast, the use of dicyano vinylcyclopropane 138c provided the desired product in moderate yields and rather moderate $E / Z$ selectivity.

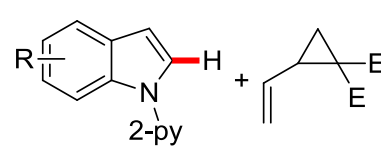

95
$\left[\mathrm{Cp}{ }^{\star} \mathrm{Co}(\mathrm{CO}) \mathrm{I}_{2}\right](10 \mathrm{~mol} \%)$

$\mathrm{AgSbF}_{6}(20 \mathrm{~mol} \%)$

$\underset{\mathrm{NCE}, 50^{\circ} \mathrm{C}, 20 \mathrm{~h}}{\mathrm{NaOPiv}(20 \mathrm{~mol} \%)} \rightarrow$

2-py

151

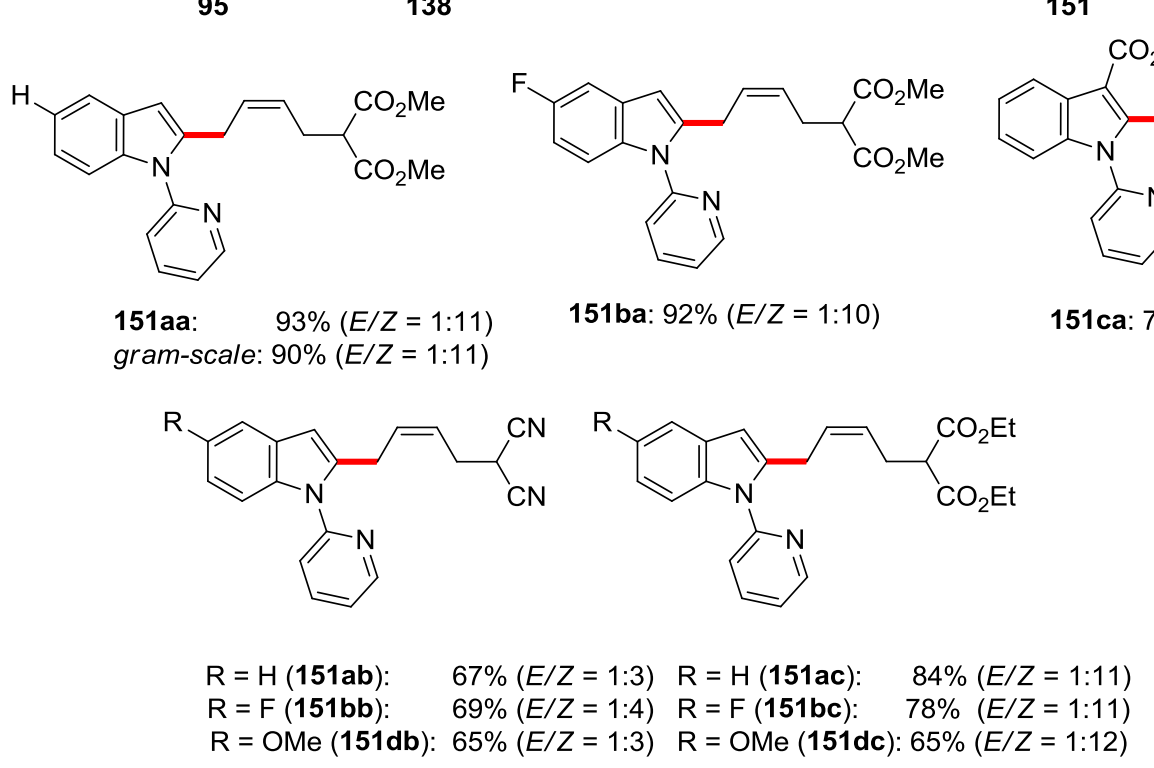

Scheme 69. Scope of the cobalt(III)-catalyzed C-H/C-C functionalization of indoles 95 and vinylcyclopropanes 138. 


\subsubsection{Comparison between Cobalt(III) and Rhodium-catalyzed $\mathrm{C}-\mathrm{H} / \mathrm{C}-\mathrm{C}$ Functionalization}

Next, under otherwise identical reaction conditions, we also probed the reactivity and selectivity of the related rhodium(III) catalyst (Scheme 70). While the less stable $Z$ diastereomer was formed with high selectivity in all cases under cobalt catalysis, rhodium(III) complexes delivered difficult-to-separate mixtures of the $E / Z$ diastereomers, with a minor bias for the $E$ diastereomer. These findings emphasize the unique diastereo-selectivities of the cobalt(III)-catalyzed $\mathrm{C}-\mathrm{H} / \mathrm{C}-\mathrm{C}$ activation.

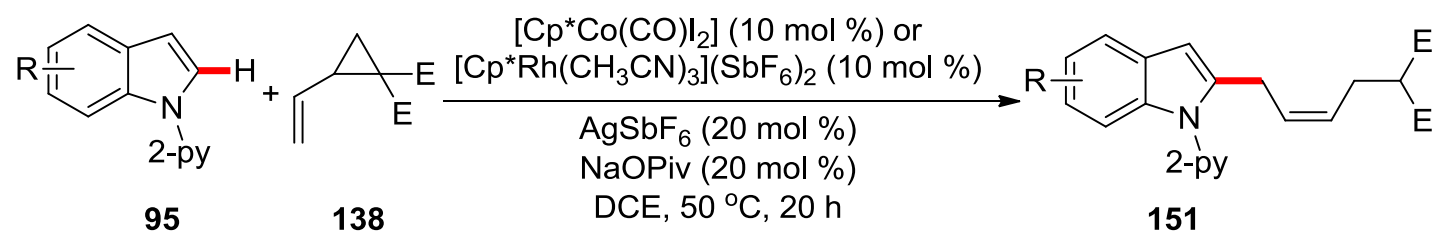<smiles>COC(=O)C(C/C=C\Cc1cc2ccccc2n1P)CC(C)=O</smiles>

[Co]: 151aa: $93 \%(E / Z=1: 11)$ [Rh]: 151aa': $77 \%(E / Z=1.8: 1)$<smiles>COC(=O)c1c(C/C=C\CC(OC)C(C)=O)n([Ga])c2ccccc12</smiles>

[Co]: $151 \mathrm{ca}: 70 \%(E / Z=1: 25)$ [Rh]: 151ca': $95 \%(E / Z=1: 1)$<smiles>[Y6]n1c(C/C=C\CC(C#N)C#N)cc2ccccc21</smiles>

[Co]: 151ab: $67 \%(E / Z=1: 3)$ [Rh]: 151ab': $69 \%(E / Z=1: 1)$<smiles>[R20]n1c(C/C=C\CC(C(=O)OCC)C(=O)OCC)cc2ccccc21</smiles>

[Co]: 151ac: $84 \%(E / Z=1: 11)$

[Rh]: 151ac': $65 \%(E / Z=1: 1)$

Scheme 70. Cobalt/Rhodium-catalyzed C-H/C-C functionalization.

\subsubsection{Scope of Arenes}

The cobalt catalyst was not restricted to the functionalization of 1-pyridylindoles. Indeed, the heteroarene-assisted diversification of arenes $\mathbf{1 5 2}$ proved broadly applicable and proceeded with high Z-diastereoselectivity (Scheme 71). Phenylpyridines were successfully converted to the desired products 153 with comparable efficiency under cobalt catalysis. It is worth to note that the cobalt catalyst was characterized by excellent chemoselectivity in that the monofunctionalized arene 
products $153 \mathrm{ba}$ was formed as the sole products. In contrast, the rhodium catalyst gave difficult to separate mixtures of mono- and di-substituted arenes 153ba' and 153ba" with low selectivity.

In the cobalt catalysis reaction, both electron-rich and electron-deficient 2-phenylpyridines provided the desired products 153 in good yield and high Z-diastereoselectivity, while under the same reaction conditions, the rhodium catalyst gave lower yields and poor $E$-diastereoselectivity. These findings show the unique diastereo- and site-selectivities of the cobalt(III)-catalyzed $\mathrm{C}-\mathrm{H} / \mathrm{C}-\mathrm{C}$ activation.

Additionaly, the reaction was found to be compatible with 1-phenyl-1H-pyrazole substrates 152c-152e, giving the desired products 153ca-153ea in higher yields and excellent diastereoselectivities compared with the rhodium catalyst. To our delight, 1-(pyridin-2-yl)-1H-pyrrole-2-carbaldehyde $\mathbf{1 5 2 \mathrm { g }}$ was successfully employed in this reaction, giving the corresponding product 153ga.

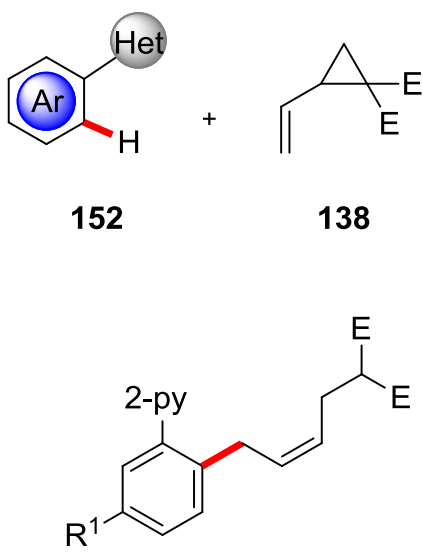

[Co]: $R^{1}=\operatorname{Me}(153 a a): \quad 70 \%(E / Z=1: 3)$

[Rh]: $R^{1}=\operatorname{Me~(153aa'):~} 34 \%(E / Z=2: 1)^{a}$

[Co]: $\mathrm{R}^{1}=\mathrm{OMe}(153 \mathrm{ba}): 63 \%(E / Z=1: 5)$

[Rh]: $\mathrm{R}^{1}=$ OMe (153ba'): $24 \%(E / Z=1: 1)+$ $14 \%$ di-sub. 153ba"a<smiles>[R6]c1cccc(F)c1C/C=C\CC(F)F</smiles>

[Co]: 153fa: $58 \%(E / Z=1: 7)$

[Rh]: 153fa': 24\% $(E / Z=1: 1)^{a}$

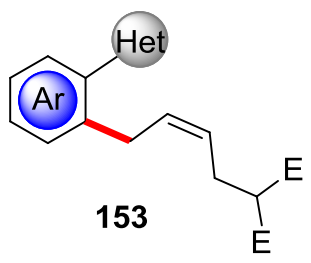<smiles>[R]c1ccc(-n2cccn2)c(C/C=C\CC(F)F)c1</smiles>

$\mathrm{R}^{1}=\mathrm{H}(153 \mathrm{ca}): \quad 71 \%(E / Z=1: 12)$

[Co]: $\mathrm{R}^{1}=\mathrm{F}(\mathbf{1 5 3 \mathrm { da }}): \quad 66 \%(E / Z=1: 14)$

[Rh]: $\mathrm{R}^{1}=\mathrm{F}\left(\right.$ 153da'): $48 \%(E / Z=1: 1)^{a}$ $\mathrm{R}^{1}=\operatorname{Me}($ 153ea $): 69 \%(E / Z=1: 19)$<smiles>O=Cc1ccc(C/C=C\CC(F)F)n1-c1ccccn1</smiles>

153ga: $78 \%(E / Z=1: 1)$

${ }^{a}\left[\mathrm{Cp}^{*} \mathrm{Rh}\left(\mathrm{CH}_{3} \mathrm{CN}\right)_{3}\right]\left(\mathrm{SbF}_{6}\right)_{2}$ was used as the catalyst. $\mathrm{E}=\mathrm{CO}_{2} \mathrm{Me}$.

Scheme 71. Cobalt-catalyzed arene $\mathrm{C}-\mathrm{H} / \mathrm{C}-\mathrm{C}$ functionalization. 
Furthermore, some limititations in the substrate scope were observed (Scheme 72). 2-(Furan-2-yl)pyridine $\quad \mathbf{1 5 2 h}, \quad 5$-(pyridin-2-yl)thiazole $\mathbf{1 5 2} \mathbf{i}$ as well as 1-(pyridin-2-yl)-1H-benzo[d]imidazole 152j unfortunately delivered no or only traces of the desired products under the optimal reaction conditions.

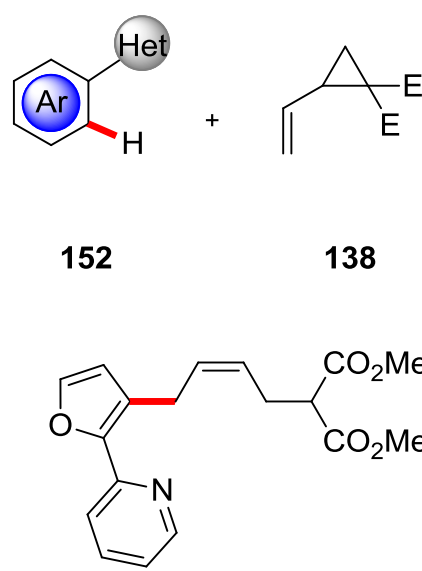

153ha: $<5 \%$

$\mathrm{E}=\mathrm{CO}_{2} \mathrm{Me}$
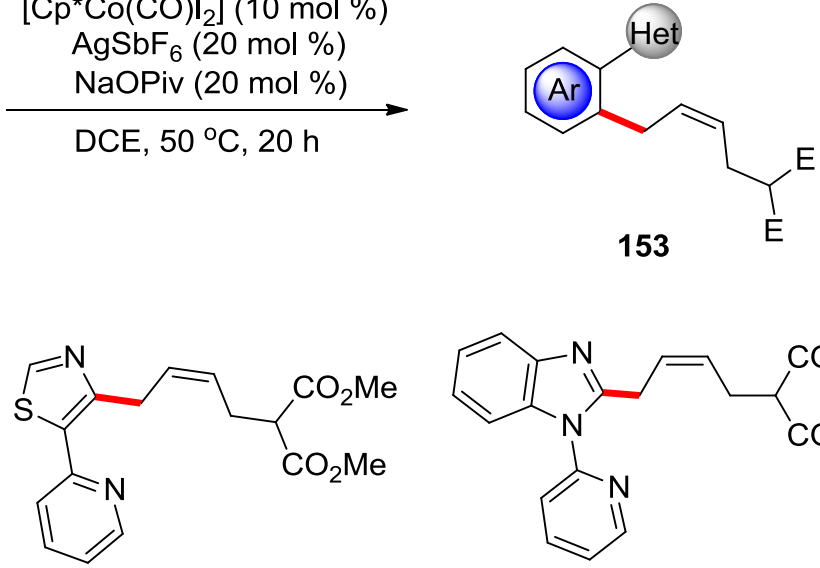

153ia: $0 \%$<smiles>COC(=O)C(CC/C=C\Cc1nc2ccccc2n1-c1ccccn1)C(C)=O</smiles>

153ja: $0 \%$

Scheme 72. Limitations of the cobalt(III)-catalyzed C-H/C-C functionalization.

\subsubsection{Isomerization Experiments}

Next, we performed several experiments to determine whether a post $\mathrm{C}-\mathrm{C}$-cleavage alkene isomerization process takes place during the catalytic reaction (Scheme 73). First, we submitted the product 151aa isolated from the cobalt(III)-catalyzed transformation to the rhodium(III) catalysis procedure, and did not observe any post-catalytic isomerization of the double bond (Scheme 73a). Likewise, the product of the rhodium catalyzed $\mathrm{C}-\mathrm{H}$ allylation did not undergo isomerization in the presence of the cobalt(III) catalyst (Scheme $73 b$ ). An $E / Z$ ratio change was observed when the product from cobalt(III) catalysis was exposed to UV light in the presence of $5 \mathrm{~mol} \%$ of $\mathrm{I}_{2}$ in $\mathrm{CH}_{2} \mathrm{Cl}_{2}$ (Scheme 73c). All the results suggested that no catalytic isomerization of the double bond occured when the E-configurated product is subjected to the optimal reaction conditions, hence excluding a post $\mathrm{C}-\mathrm{C}$ cleavage isomerisation process. 
a)<smiles>CC(=O)CC(C=CCc1cc2ccccc2n1P)COC(C)=O</smiles>

$(Z)-151$ aa $(E / Z=1: 11)$
$\left[\mathrm{Cp}^{*} \mathrm{Rh}\left(\mathrm{CH}_{3} \mathrm{CN}\right)_{3}\right]\left(\mathrm{SbF}_{6}\right)_{2}$

$$
\text { (10 } \mathrm{mol} \%)
$$

NaOPiv $(20 \mathrm{~mol} \%) \rightarrow$ DCE (1 mL), $20 \mathrm{~h}, 50^{\circ} \mathrm{C}$ No change in E/Z-ratio<smiles>CC(=O)CC(C=CCc1cc2ccccc2n1P)C(C)=O</smiles>

(Z)-151aa $(E / Z=1: 11): 89 \%$ b)<smiles>COC(=O)C(C=CCc1cc2ccccc2n1[Pb])CC(C)=O</smiles>

$(E)-151 \mathrm{aa} \mathbf{a}^{\prime}(E / Z=1.8: 1)$
$\left[\mathrm{Cp}^{*} \mathrm{Co}(\mathrm{CO}) \mathrm{I}_{2}\right](10 \mathrm{~mol} \%)$
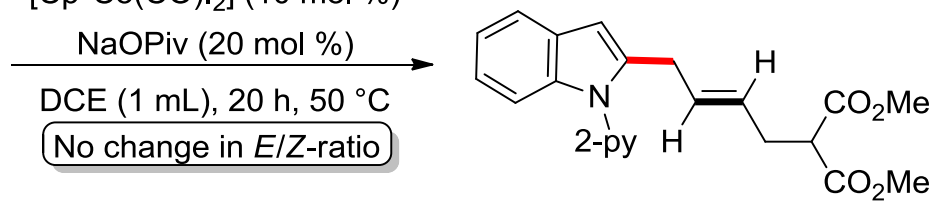

(E)-151aa' $(E / Z=1.8: 1): 94 \%$

c)<smiles>COC(C)=CCC(C)CCc1cc2ccccc2n1P</smiles>

$(Z)-151 \mathbf{a a}(E / Z=1: 11)$

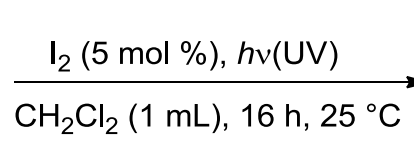

(Z)-151aa" (E/Z = 1:2): 83\%

Scheme 73. Isomerization experiments.

\subsubsection{Proposed Catalytic Cycle}

Based on our mechanistic studies, we propose the cobalt(III)-catalyzed $\mathrm{C}-\mathrm{H} / \mathrm{C}-\mathrm{C}$ functionalization to commence by a reversible $\mathrm{C}-\mathrm{H}$ activation, which is assisted by the pivalate additive and presumably proceeds via a base-assisted internal electrophilic-type substitution (BIES)-type mechanistic pathway ${ }^{[129,120 a]}$ to furnish the cobaltacycle 155. Starting from the next step, computational studies by DFT calculations was performed by Dr. M. Feldt. ${ }^{[127]}$ The coordination of vinylcyclopropane 138a then delivers intermediate 156, in which migratory insertion of the double bond of the coordinated vinylcyclopropane 138a into the $\mathrm{Co}-\mathrm{C}$ bond occurs. Thereafter, an ester group coordinates to the metal center, thereby leading to intermediate 157 . Then, the rate- and diastereoselectivity-determining $\mathrm{C}-\mathrm{C}$ cleavage of vinylcyclopropane take place to form the Z-configurated intermediate 158 (Scheme 74).

Comparing the energetic $\operatorname{span}^{[130]}$ for the vinylcyclopropane $\mathrm{C}-\mathrm{C}$ cleavage step, the $Z$ diastereomer is clearly preferred under cobalt(III) catalysis, with an activation barrier of $13.1 \mathrm{kcalmol}^{-1}$ compared to 
$19.6 \mathrm{kcalmol}^{-1}$ for the $E$ diastereomer. In contrast, with the rhodium(III) catalyst, the $E$ diastereomer is preferred with an energetic span of $20.9 \mathrm{kcalmol}^{-1}$ compared to $23.2 \mathrm{kcalmol}^{-1}$ for the $Z$ diastereomer. This observation is likely due to the significantly shorter $\mathrm{Co}-\mathrm{C}$ bonds translating into more compact organometallic species. Finally, the desired product 151aa is released by a protodemetalation step, which also regenerates the active catalyst $\mathbf{1 5 4}$.

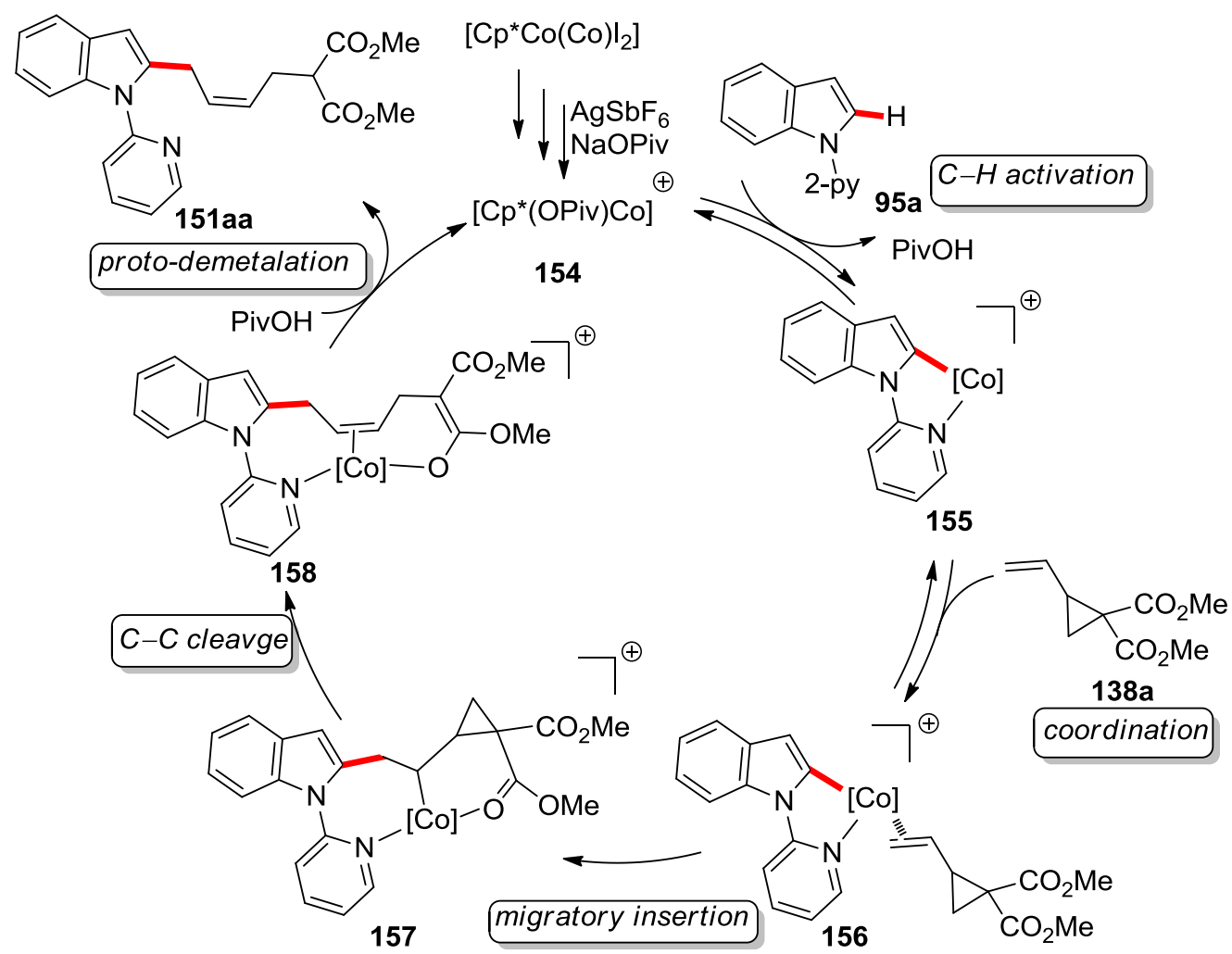

Scheme 74. Proposed catalytic cycle for the cobalt(III)-catalyzed C-H/C-C activation. $[\mathrm{Co}]=\mathrm{Cp}^{*} \mathrm{Co}^{\mathrm{II}}$ 


\section{Summary and Outlook}

In the first project, an efficient $\mathrm{C}-\mathrm{H}$ alkenylation of challenging arylacetamides by ruthenium(II) catalysis through challenging six-membered ruthenacycles was developed (Scheme 75). Under the optimal reaction conditions, various acetamides 132 including tertiary, secondary, and even primary amides could be converted to the corresponding olefins with high levels of chemo-, position and stereo-selectivity. By simply switching the carboxylate source from $\mathrm{Cu}(\mathrm{OAc})_{2} \cdot \mathrm{H}_{2} \mathrm{O}$ to $1-\mathrm{AdCO}_{2} \mathrm{H}$, substituted olefins $\mathbf{1 3 3}$ were also obtained by step- and atom economical alkyne hydroarylations.

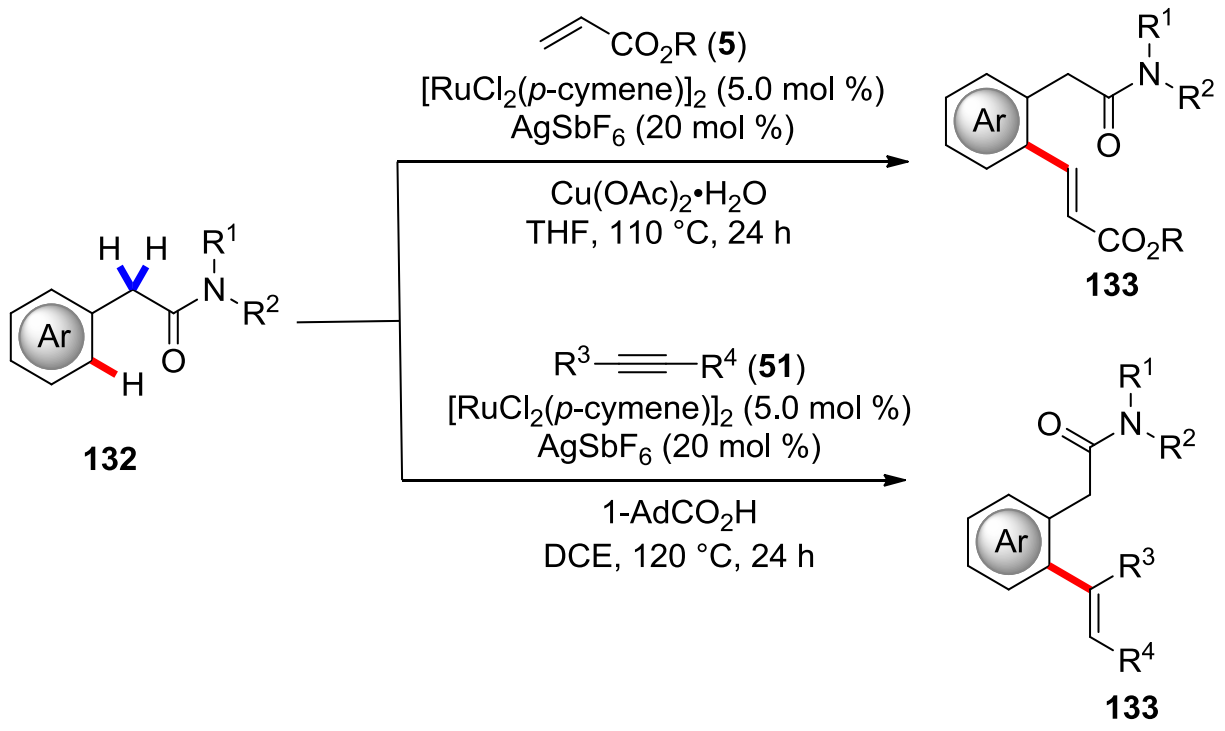

Scheme 75. Ruthenium(II)-catalyzed C-H alkenylation of weakly $O$-coordinating arylacetamides 132.

Inspired by the above-mentioned ruthenium(II)-catalyzed $\mathrm{C}-\mathrm{H}$ activations of arylacetamides, we subsequently achieved the first ruthenium-catalyzed $\mathrm{C}-\mathrm{H}$ oxygenation of weakly $\mathrm{O}$-coordinating arylacetamides (Scheme 76). This powerful synthetic tool allowed for the rapid and site-selective installation of hydroxyl groups into acetamides. Furthermore, the ruthenium(II) catalyst also allowed for the direct $\mathrm{C}-\mathrm{H}$ functionalization on more challenging weakly-coordinating phenylacetyl esters. 


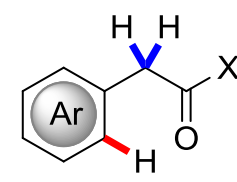

132 or 134

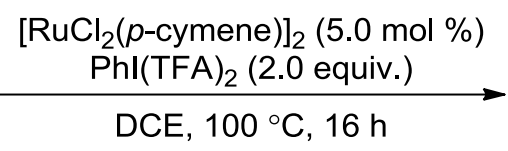

DCE, $100^{\circ} \mathrm{C}, 16 \mathrm{~h}$

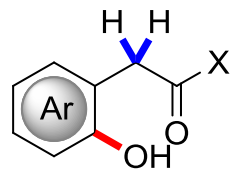

$135 \mathrm{X}=\mathrm{OR}, \mathrm{NR}_{2}$

Scheme 76. Ruthenium(II)-catalyzed C-H oxygenation by weakly coordinating acetamides or esters.

In the third project, we developed an efficient cobalt catalyst for the direct Hiyama-type $\mathrm{C}-\mathrm{H}$ arylation of beazamides with a variety of organosilanes (Scheme 77). The reaction tolerated a broad variety of functional groups and numerous ortho-arylated benzamides 137 were efficiently synthesized in good to excellent yields. The steric hindrance of the organosilanes was especially tolerated, providing arylated products $\mathbf{1 3 7}$ in good to excellent yields. Additionaly, the cost-effective cobalt catalyst was also viable in biomass-derived GVL as a green reaction medium.

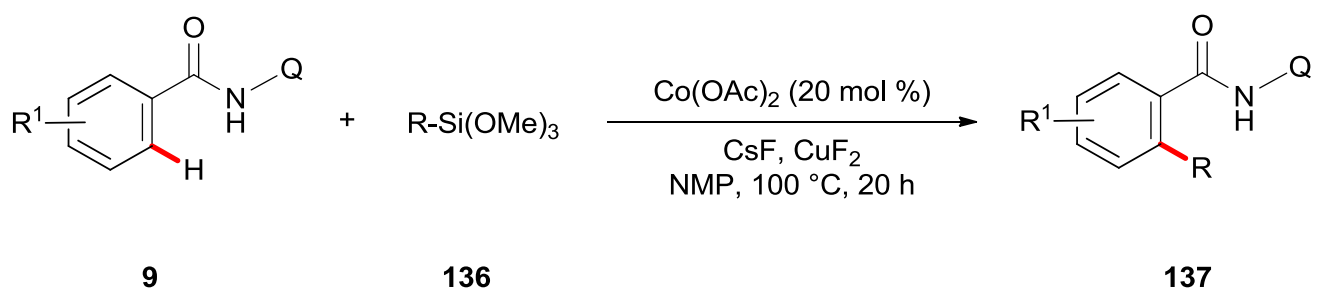

Scheme 77. Cobalt-catalyzed $\mathrm{C}-\mathrm{H}$ arylation.

Finally, we developed a cobalt-catalyzed $\mathrm{C}-\mathrm{H} / \mathrm{C}-\mathrm{C}$ functionalization of valuable heteroarenes and arenes 152 with vinylcyclopropanes 138 (Scheme 78). The thermodynamically less stable Z-configurated diastereomer was obtained using a versatile cobalt catalyst under exceedingly mild reaction conditions with high diastereo-selectivity, ample scope and excellent functional group tolerance. The obtained selectivity was different using the related rhodium(III) complex, ${ }^{[125]}$ which delivered difficult to separate mixtures of $E / Z$ diastereomers, with a minor bias for the $E$ diastereomer. Additionally, detailed mechanistic studies including DFT calculations provided strong support for a rate-and selectivity-determining $\mathrm{C}-\mathrm{C}$ cleavage. 


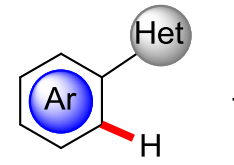

152

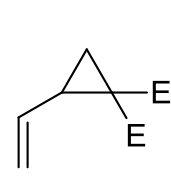

138
$\left[\mathrm{Cp}{ }^{*} \mathrm{Co}(\mathrm{CO}) \mathrm{I}_{2}\right](10 \mathrm{~mol} \%)$

$\mathrm{AgSbF}_{6}(20 \mathrm{~mol} \%)$

NaOPiv $(20 \mathrm{~mol} \%)$

DCE, $50^{\circ} \mathrm{C}, 20 \mathrm{~h}$

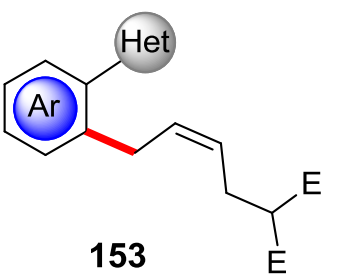

Scheme 78. Cobalt(III)-catalyzed C-H/C-C functionalization. 


\section{Experimental Section}

\subsection{General Remarks}

Unless otherwise noted, all catalytic reactions were performed under an Ar or $\mathrm{N}_{2}$ atmosphere using pre-dried glassware and standard Schlenk techniques.

\section{Solvents}

All solvents for reactions involving moisture-sensitive reagents were dried, distilled and stored under an inert atmosphere according to the following standard procedures.

1,4-Dioxane was dried over $\mathrm{Na}$, benzophenone and distilled afterwards.

Dichloromethane (DCM), $\mathbf{N}, \mathbf{N}$-dimethylformamide (DMF) and tetrahydrofuran (THF) were purified using a solvent purification system (SPS) from Mbraun.

Methanol $(\mathrm{MeOH})$ was distilled from $\mathrm{MgOMe}$.

1,2-Dichloroethane (DCE) and 1,3-dimethyl-3,4,5,6-tetrahydro-2(1H)-pyrimidinone (DMPU) were dried over $\mathrm{CaH}_{2}$ for $8 \mathrm{~h}$, degassed and distilled under reduced pressure.

$\mathrm{N}$-Methyl-2-pyrrolidone (NMP) was dried over $\mathrm{CaH}_{2}$ for $4 \mathrm{~h}$ at $150{ }^{\circ} \mathrm{C}$ and subsequently distilled under reduced pressure.

tert-amylalcohol $(t-\mathrm{AmOH})$ was used as supplied by Merck or stirred over sodium chips for $5 \mathrm{~h}$ at $120^{\circ} \mathrm{C}$ and then distilled at ambient pressure.

Water $\left(\mathrm{H}_{2} \mathrm{O}\right)$ was degassed before its use, applying a repeated freeze-pump-thaw degassing procedure.

Toluene was pre-dried over KH followed by distillation from sodium benzophenone.

\section{Vacuum}

The following pressures were measured on the used vacuum pump and were not corrected: membrane pump vacuum (MPV): 0.5 mbar, oil pump vacuum (OPV): 0.1 mbar.

\section{Melting Points (M. p.)}

Melting points were measured, using a Stuart ${ }^{\circledR}$ Melting Point Apparatus SMP3 from Barloworldscientific. Reported values are uncorrected. 


\section{Chromatography}

Analytical thin layer chromatography (TLC) was performed on $0.25 \mathrm{~mm}$ silica gel 60F-plates (Merck) with $254 \mathrm{~nm}$ fluorescent indicator from Merck. Plates were visualized under UV-light or developed by treatment with a $\mathrm{KMnO}_{4}$ solution followed by carefully heating. Chromatographic purification of products was accomplished by flash column chromatography on MERCK silica gel, grade 60 (0.040-0.063 $\mathrm{mm}$ and $0.063-0.200 \mathrm{~mm})$.

\section{Gas Chromatography (GC)}

The conversion of the reactions was monitored by coupled gas chromatography/mass spectrometry using G1760C GCDplus with mass detector HP 5971, 5890 Series II with mass detector HP 5972 from HEWLETT-PACKARD and 7890A GC-System with mass detector 5975C (Triplex-Axis-Detector) from AGILENT TECHNOLOGIES equipped with HP-5MS columns (30 m $\times 0.25 \mathrm{~mm}, \varnothing 0.25 \mathrm{~m})$.

\section{High Performance Liquid Chromatography (HPLC)}

Preparative and analytical separations were performed on an HPLC-System from KNAUER (Smartline Pump 100, Dynamic Mixing Chamber, Injection-and Control-Valve, Smartline UV Detector 2500). Separation normal phase column $(250 \times 10 \mathrm{~mm})$ from MACHEREY-NAGEL (MN) was used. Organic solvents of HPLC grade were employed. All samples were filtered through Polytetrafluoroethylene Filter from ROTH $(\varnothing 25 \mathrm{~mm}, 0.2 \mu \mathrm{m})$ or VWR $(\varnothing 13 \mathrm{~mm}, 0.2 \mu \mathrm{m})$ prior to separation.

\section{Nuclear Magnetic Resonance Spectroscopy (NMR)}

Nuclear magnetic resonance (NMR) spectroscopy was performed at 300, 400, 500 or $600 \mathrm{MHz}\left({ }^{1} \mathrm{H}\right.$ NMR), 75, 100 or $125 \mathrm{MHz}\left({ }^{13} \mathrm{C}\right.$ NMR, APT) and $283 \mathrm{MHz}$ or $471 \mathrm{MHz}\left({ }^{19} \mathrm{~F}\right.$ NMR) on BRUKER AM 250, VARIAN Unity-300 and Inova 500 instruments. Chemical shifts were reported as $\delta$-values in ppm relative to the residual proton peak of the deuterated solvent or its carbon atom, respectively, or the standard trimethylsilyl (TMS) peak.

\section{Infrared Spectroscopy (IR)}

Infrared spectra were recorded on a BrukerAlpha-P ATR-spectrometer. Liquid probes were measured as films between the plates of $\mathrm{NaCl}$ and solid probes neat applying Attenuated Total 
Reflection (ATR) technique, which enabled the samples to be examined directly. Analysis of the spectral data has been done by using the OPUS 3.1 software from Bruker, respectively OPUS 6 . Absorption ( $\tilde{v})$ was given in wave numbers $\left(\mathrm{cm}^{-1}\right)$. Spectra were recorded in the range of 4000 to 400 $\mathrm{cm}^{-1}$.

\section{Mass Spectrometry (MS)}

MS (EI) and HR-MS (EI) were measured on a Time-of-Flight mass spectrometer AccuTOF from JOEL. ESI-mass spectra were recorded on an Ion-Trap mass spectrometer $L C Q$ from FINNIGAN or on a Time-of-Flight mass spectrometer microTOF from BRUKER. ESI-HR-MS spectra were recorded on a BRUKER APEX IV or a BRUKER DALTONIC mass spectrometer. The ratios of mass to charge $(\mathrm{m} / \mathrm{z})$ were indicated, intensities relative to the base peak $(\mathrm{I}=100)$ were written in parentheses.

\section{Reagents}

Chemicals obtained from commercial sources with purity above $95 \%$ were used without further purification. The following compounds are known and were synthesized according to previously described methods: Arylacetamides $\quad \mathbf{1 3 2},{ }^{[131]} \quad\left[\mathrm{Cp}^{*} \mathrm{CoI}_{2}(\mathrm{CO})\right],{ }^{[132]}$ $\left[\mathrm{Cp}^{*} \mathrm{CoI}_{2}\right]_{2},{ }^{[133]}\left[\mathrm{Cp} * \mathrm{Co}(\mathrm{MeCN})_{3}\right]\left(\mathrm{SbF}_{6}\right)_{2},{ }^{[134]}$ indoles 95. ${ }^{[135]}$

The following compounds were obtained by the generous courtesy of the persons indicated below:

Karsten Rauch: $\left[\mathrm{Ru}\left(\mathrm{O}_{2} \mathrm{CMes}\right)_{2}(p\right.$-cymene $\left.)\right],\left[\mathrm{RuCl}_{2}(p \text {-cymene })\right]_{2},\left[\mathrm{Cp} * \mathrm{Rh}\left(\mathrm{CH}_{3} \mathrm{CN}\right)_{3}\right]\left(\mathrm{SbF}_{6}\right)_{2}$.

M. Sc. Joachim Loup: $\left[\mathrm{Co}(\mathrm{CO}) \mathrm{Cp}^{1,3-t-\mathrm{Bu}} \mathrm{I}_{2}\right],\left[\mathrm{Co}(\mathrm{CO}) \mathrm{CpI}_{2}\right]$.

Dr. Vladislav Kotek: $N$-(tert-butyl)-2-phenylacetamide 132i, 1-morpholino-2-phenylethanone 132k, 2-phenyl-1-(pyrrolidin-1-yl)ethanone 132l, $N$-(tert-butyl)-2-(4-fluorophenyl)acetamide 132p, $N$-(tert-butyl)-2-(4-methoxyphenyl)acetamide 132q.

M. Sc. Krzysztof Kuciński: (2,6-Dimethylphenyl)trimethoxysilane 136b, mesityltrimethoxysilane 131c, trimethoxy(4-methoxyphenyl)silane 136h.

M. Sc. Yujiao Zhang: 1-(Pyridin-2-yl)-1H-indole 95a, 5-fluoro-1-(pyridin-2-yl)-1H-indole 95b. 


\subsection{General Procedures}

\subsubsection{General Procedure A: Ruthenium-Catalyzed Oxidative C-H Alkenylations}

A suspension of arylacetamide 132 ( $0.5 \mathrm{mmol}, 1.0$ equiv), acrylate 5 (1.0 mmol, 2.0 equiv), $\left[\mathrm{RuCl}_{2}(p \text {-cymene })\right]_{2}(15.3 \mathrm{mg}, 5.0 \mathrm{~mol} \%), \mathrm{AgSbF}_{6}(34.4 \mathrm{mg}, 20 \mathrm{~mol} \%), \mathrm{Cu}(\mathrm{OAc})_{2} \cdot \mathrm{H}_{2} \mathrm{O}(1.0 \mathrm{mmol}$, 2.0 equiv) in 1,4-dioxane or THF $(2.0 \mathrm{~mL})$ was stirred at $110{ }^{\circ} \mathrm{C}$ for $24 \mathrm{~h}$ under $\mathrm{N}_{2}$ atmosphere. At ambient temperature, the reaction mixture was diluted with sat. aq. $\mathrm{NH}_{4} \mathrm{Cl}(10 \mathrm{~mL})$ and extracted with EtOAc $(3 \times 25 \mathrm{~mL})$. The combined organic layers were dried over $\mathrm{Na}_{2} \mathrm{SO}_{4}$. After filtration and evaporation of the solvents in vacuo, the remaining residue was purified by column chromatography on silica gel ( $n$-hexane/acetone).

\subsubsection{General Procedure B: Ruthenium-Catalyzed Hydroarylation of Alkynes}

A suspension of acetamide 132 ( $0.5 \mathrm{mmol}, 1.0$ equiv), alkyne 51 (1.0 mmol, 2.0 equiv), $\left[\mathrm{RuCl}_{2}(p \text {-cymene) }]_{2}(15.3 \mathrm{mg}, 5.0 \mathrm{~mol} \%), \mathrm{AgSbF}_{6}(34.4 \mathrm{mg}, 20 \mathrm{~mol} \%), 1-\mathrm{AdCO}_{2} \mathrm{H}(0.5 \mathrm{mmol}, 1.0\right.$ equiv) in DCE $(2.0 \mathrm{~mL})$ was stirred at $120{ }^{\circ} \mathrm{C}$ for $24 \mathrm{~h}$ under $\mathrm{N}_{2}$ atmosphere. At ambient temperature, the solvent was removed in vacuo and the remaining residue was purified by column chromatography on silica gel ( $n$-hexane/EtOAc).

\subsubsection{General Procedure C: Ruthenium-Catalyzed C-H Oxygenation}

$\left[\mathrm{RuCl}_{2}(\mathrm{p} \text {-cymene })\right]_{2}(15.3 \mathrm{mg}, 5.0 \mathrm{~mol} \%)$, arylacetamide or phenylacetyl ester 132 or $134(0.50$ mmol $), \mathrm{PhI}(\mathrm{TFA})_{2}(430 \mathrm{mg}, 1.00 \mathrm{mmol})$ and DCE $(2.0 \mathrm{~mL})$ were placed into a $25 \mathrm{~mL}$ Schlenk tube equipped with a septum under $\mathrm{N}_{2}$. The tube was then placed into an oil bath and the reaction mixture was stirred at $110{ }^{\circ} \mathrm{C}$ for $16 \mathrm{~h}$. At ambient temperature, the reaction mixture was diluted with $\mathrm{H}_{2} \mathrm{O}$ $(15 \mathrm{~mL})$ and extracted with EtOAc $(3 \times 15 \mathrm{~mL})$. The combined organic layer was concentrated under reduced pressure. The crude products were purified by column chromatography ( $n$-hexane/EtOAc) on silica gel to afford the desired products $\mathbf{1 3 5 .}$

\subsubsection{General Procedure D: Cobalt-Catalyzed C-H Arylation}

A suspension of benzamide 9 ( $0.25 \mathrm{mmol}, 1.0$ equiv $)$, arylsilane $136(0.5 \mathrm{mmol}, 2.0$ equiv $), \mathrm{Co}(\mathrm{OAc})_{2}$ (8.9 mg, $20.0 \mathrm{~mol} \%), \mathrm{CsF}$ (0.75 mmol, 3.0 equiv), $\mathrm{CuF}_{2}(0.5 \mathrm{mmol}, 2.0$ equiv) in NMP (1.0 mL) was stirred at $100{ }^{\circ} \mathrm{C}$ for $20 \mathrm{~h}$ under $\mathrm{N}_{2}$ atmosphere. At ambient temperature, the reaction mixture was diluted with water $(30 \mathrm{~mL})$ and extracted with $\mathrm{CH}_{2} \mathrm{Cl}_{2}(3 \times 50 \mathrm{~mL})$. The combined organic layers were 
dried over $\mathrm{Na}_{2} \mathrm{SO}_{4}$. After filtration and evaporation of the solvents in vacuo, the remaining residue was purified by column chromatography on silica gel ( $n$-hexane/acetone).

\subsubsection{General Procedure E: Cobalt-Catalyzed C-H Arylation in GVL}

A suspension of benzamide 9 ( $0.25 \mathrm{mmol}, 1.0$ equiv), arylsilane $136(0.5 \mathrm{mmol}, 2.0$ equiv $), \mathrm{Co}(\mathrm{OAc})_{2}$ (8.9 mg, $20.0 \mathrm{~mol} \%), \mathrm{CsF}$ (0.375 mmol, 1.5 equiv), $\mathrm{CuF}_{2}$ (0.5 mmol, 2.0 equiv) in GVL (1.0 mL) was stirred at $120{ }^{\circ} \mathrm{C}$ for $20 \mathrm{~h}$ under $\mathrm{N}_{2}$ atmosphere. At ambient temperature, the reaction mixture was diluted with $\mathrm{CH}_{2} \mathrm{Cl}_{2}(15 \mathrm{~mL})$ and washed with $\mathrm{NaOH}(2 \mathrm{M}, 10 \mathrm{~mL})$ and $\mathrm{H}_{2} \mathrm{O}(2 \times 20 \mathrm{~mL})$. The combined organic layers were dried over $\mathrm{Na}_{2} \mathrm{SO}_{4}$. After filtration and evaporation of the solvents in vacuo, the remaining residue was purified by column chromatography on silica gel (n-hexane/acetone).

\subsubsection{General Procedure F: Cobalt(III)-Catalyzed C-H/C-C Functionalization}

A suspension of indole 95 or heteroarene 152 (0.50 mmol, 1.0 equiv), vinylcyclopropanes 138 (0.60 mmol, 1.2 equiv), [Cp* $\left.\mathrm{Co}(\mathrm{CO}) \mathrm{I}_{2}\right](23.8 \mathrm{mg}, 50.0 \mu \mathrm{mol}, 10 \mathrm{~mol} \%), \mathrm{AgSbF}_{6}(34.4 \mathrm{mg}$, $100 \mu \mathrm{mol}, 20 \mathrm{~mol} \%)$ and NaOPiv (12.4 mg, $100 \mu \mathrm{mol}, 20 \mathrm{~mol} \%)$ in DCE (1.0 mL, $0.50 \mathrm{M})$ was stirred at $50{ }^{\circ} \mathrm{C}$ for $20 \mathrm{~h}$. At ambient temperature, the solvent was removed in vacuo and the remaining residue was purified by column chromatography on silica gel to afford the desired products 146 or 148 .

\subsubsection{General Procedure G: Rhodium(III)-Catalyzed C-H/C-C Functionalization}

A suspension of indole 95 or heteroarene 147 (0.25 mmol, 1.0 equiv), vinylcyclopropane 133 (0.30 mmol, 1.2 equiv), $\left[\mathrm{Cp}^{*} \mathrm{Rh}\left(\mathrm{CH}_{3} \mathrm{CN}\right)_{3}\right]\left(\mathrm{SbF}_{6}\right)_{2}(19.7 \mathrm{mg}, 25.0 \mu \mathrm{mol}, 10 \mathrm{~mol} \%)$ and $\mathrm{NaOPiv}$ $(6.2 \mathrm{mg}, 50.0 \mu \mathrm{mol}, 20 \mathrm{~mol} \%)$ in DCE $(1.0 \mathrm{~mL}, 0.25 \mathrm{M})$ was stirred at $50{ }^{\circ} \mathrm{C}$ for $20 \mathrm{~h}$. At ambient temperature, the solvent was removed in vacuo and the remaining residue was purified by column chromatography on silica gel to afford the desired products 151 or 153. 


\subsection{Experimental Procedures and Analytical Data}

\subsubsection{Ruthenium-Catalyzed Oxidative C-H Alkenylations of Arylactamides}<smiles>CCOC(=O)/C=C/c1ccccc1CC(N)=O</smiles>

\section{(E)-n-Butyl 3-[2-(2-amino-2-oxoethyl)phenyl]acrylate (133aa):}

The general procedure $\mathbf{A}$ was followed using 2-phenylacetamide (132a) (67.5 $\mathrm{mg}, 0.50 \mathrm{mmol}$ ) and $n$-butyl acrylate (5a) (128 mg, $1.00 \mathrm{mmol})$. Isolation by column chromatography ( $n$-hexane/acetone: 3/1) yielded 133aa (84 mg, 64\%) as a white solid.

M. p. $=118-119^{\circ} \mathrm{C}$.

${ }^{1} \mathbf{H}$ NMR $\left(400 \mathrm{MHz}, \mathrm{CDCl}_{3}\right): \delta=7.91(\mathrm{~d}, J=15.8 \mathrm{~Hz}, 1 \mathrm{H}), 7.63-7.60(\mathrm{~m}, 1 \mathrm{H}), 7.39-7.28(\mathrm{~m}, 3 \mathrm{H})$, $6.38(\mathrm{~d}, J=15.8 \mathrm{~Hz}, 1 \mathrm{H}), 5.74\left(\mathrm{~s}_{\mathrm{br}}, 1 \mathrm{H}\right), 5.46\left(\mathrm{~s}_{\mathrm{br}}, 1 \mathrm{H}\right), 4.19(\mathrm{t}, J=6.7 \mathrm{~Hz}, 2 \mathrm{H}), 3.72(\mathrm{~s}, 2 \mathrm{H}), 1.68(\mathrm{dt}$, $J=14.6,6.8 \mathrm{~Hz}, 2 \mathrm{H}), 1.42(\mathrm{dd}, J=14.6,7.5 \mathrm{~Hz}, 2 \mathrm{H}), 0.96(\mathrm{t}, J=7.4 \mathrm{~Hz}, 3 \mathrm{H})$.

${ }^{13}$ C NMR $\left(100 \mathrm{MHz}, \mathrm{CDCl}_{3}\right): \delta=172.3\left(\mathrm{C}_{\mathrm{q}}\right), 166.6\left(\mathrm{C}_{\mathrm{q}}\right), 141.0(\mathrm{CH}), 134.2\left(\mathrm{C}_{\mathrm{q}}\right), 134.1\left(\mathrm{C}_{\mathrm{q}}\right), 131.3$ $(\mathrm{CH}), 130.4(\mathrm{CH}), 128.1(\mathrm{CH}), 127.2(\mathrm{CH}), 121.1(\mathrm{CH}), 64.6\left(\mathrm{CH}_{2}\right), 40.6\left(\mathrm{CH}_{2}\right), 30.7\left(\mathrm{CH}_{2}\right), 19.2$ $\left(\mathrm{CH}_{2}\right), 13.7\left(\mathrm{CH}_{3}\right)$.

IR (ATR): 2959, 1710, 1660, 1626, 1310, 1165, $766 \mathrm{~cm}^{-1}$.

MS (ESI) $m / z$ (relative intensity): $545(100)[2 \mathrm{M}+\mathrm{Na}]^{+}, 284(45)[\mathrm{M}+\mathrm{Na}]^{+}, 262(27)[\mathrm{M}+\mathrm{H}]^{+}$.

HR-MS (ESI) $m / z$ calcd for $\mathrm{C}_{15} \mathrm{H}_{20} \mathrm{NO}_{3}[\mathrm{M}+\mathrm{H}]^{+}: 262.1438$, found: 262.1435. 
<smiles>CCOC(=O)/C=C/c1cc(Br)ccc1CC(N)=O</smiles>

\section{(E)-n-Butyl 3-[2-(2-amino-2-oxoethyl)-5-bromophenyl]acrylate (133ba):}

The general procedure $\mathbf{A}$ was followed using 2-(4-bromophenyl)acetamide (132b) (106 mg, 0.50 mmol) and $n$-butyl acrylate (5a) $(128 \mathrm{mg}, 1.00 \mathrm{mmol})$. Isolation by column chromatography (n-hexane/acetone: $3 / 1)$ yielded $\mathbf{1 3 3 b a}(104 \mathrm{mg}, 61 \%)$ as a white solid.

M. p. $=165-166^{\circ} \mathrm{C}$

${ }^{1}$ H NMR $\left(300 \mathrm{MHz}, \mathrm{CDCl}_{3}\right): \delta=7.79(\mathrm{~d}, J=15.8 \mathrm{~Hz}, 1 \mathrm{H}), 7.72(\mathrm{~d}, J=2.1 \mathrm{~Hz}, 1 \mathrm{H}), 7.46(\mathrm{dd}, J=8.2$, $2.1 \mathrm{~Hz}, 1 \mathrm{H}), 7.16(\mathrm{~d}, J=8.2 \mathrm{~Hz}, 1 \mathrm{H}), 6.36(\mathrm{~d}, J=15.8 \mathrm{~Hz}, 1 \mathrm{H}), 5.58\left(\mathrm{~s}_{\mathrm{br}}, 1 \mathrm{H}\right), 5.44\left(\mathrm{~s}_{\mathrm{br}}, 1 \mathrm{H}\right), 4.18(\mathrm{t}, J$ $=6.7 \mathrm{~Hz}, 2 \mathrm{H}), 3.64(\mathrm{~s}, 2 \mathrm{H}), 1.74-1.60(\mathrm{~m}, 2 \mathrm{H}), 1.48-1.33(\mathrm{~m}, 2 \mathrm{H}), 0.94(\mathrm{t}, J=7.5 \mathrm{~Hz}, 3 \mathrm{H})$.

${ }^{13}$ C NMR (125 MHz, $\left.\mathrm{CDCl}_{3}\right): \delta=170.6\left(\mathrm{C}_{\mathrm{q}}\right), 165.4\left(\mathrm{C}_{\mathrm{q}}\right), 138.8(\mathrm{CH}), 135.3\left(\mathrm{C}_{\mathrm{q}}\right), 132.3(\mathrm{CH}), 132.1$ $\left(\mathrm{C}_{\mathrm{q}}\right), 131.9(\mathrm{CH}), 129.2(\mathrm{CH}), 121.5(\mathrm{CH}), 121.2\left(\mathrm{C}_{\mathrm{q}}\right), 64.0\left(\mathrm{CH}_{2}\right), 39.2\left(\mathrm{CH}_{2}\right), 30.0\left(\mathrm{CH}_{2}\right), 18.4\left(\mathrm{CH}_{2}\right)$, $13.1\left(\mathrm{CH}_{3}\right)$.

IR (ATR): 2957, 1712, 1657, 1312, 1173, 975, $806 \mathrm{~cm}^{-1}$.

MS (ESI) $m / z$ (relative intensity): $362(100)\left([\mathrm{M}+\mathrm{Na}]^{+},{ }^{79} \mathrm{Br}\right), 342(23)\left([\mathrm{M}+\mathrm{H}]^{+},{ }^{81} \mathrm{Br}\right)$.

HR-MS (ESI) $m / z$ calcd for $\mathrm{C}_{15} \mathrm{H}_{19}{ }^{79} \mathrm{BrNO}_{3}[\mathrm{M}+\mathrm{H}]^{+}: 340.0543$, found: 340.0540 .<smiles>CCOC(=O)/C=C/c1cc(Cl)ccc1CC(N)=O</smiles>

(E)-n-Butyl 3-[2-(2-amino-2-oxoethyl)-5-chlorophenyl]acrylate (133ca):

The general procedure $\mathbf{A}$ was followed using 2-(4-chlorophenyl)acetamide (132c) (84.5 mg, 0.50 mmol) and $n$-butyl acrylate (5a) (128 $\mathrm{mg}, 1.00 \mathrm{mmol})$. Isolation by column chromatography ( $n$-hexane/acetone: $3 / 1$ ) yielded 133ca (97 $\mathrm{mg}, 66 \%$ ) as a white solid.

M. p. $=153-154^{\circ} \mathrm{C}$.

${ }^{1} \mathbf{H}$ NMR $\left(300 \mathrm{MHz}, \mathrm{CDCl}_{3}\right): \delta=7.80(\mathrm{~d}, J=15.8 \mathrm{~Hz}, 1 \mathrm{H}), 7.57(\mathrm{~d}, J=2.2 \mathrm{~Hz}, 1 \mathrm{H}), 7.32(\mathrm{dd}, J=7.6$, $2.2 \mathrm{~Hz}, 1 \mathrm{H}), 7.22(\mathrm{~d}, J=7.6 \mathrm{~Hz}, 1 \mathrm{H}), 6.37(\mathrm{~d}, J=15.8 \mathrm{~Hz}, 1 \mathrm{H}), 5.50\left(\mathrm{~s}_{\mathrm{br}}, 1 \mathrm{H}\right), 5.42\left(\mathrm{~s}_{\mathrm{br}}, 1 \mathrm{H}\right), 4.18(\mathrm{t}, J$ $=6.7 \mathrm{~Hz}, 2 \mathrm{H}), 3.66(\mathrm{~s}, 2 \mathrm{H}), 1.70-1.61(\mathrm{~m}, 2 \mathrm{H}), 1.46-1.35(\mathrm{~m}, 2 \mathrm{H}), 0.94(\mathrm{t}, J=7.3 \mathrm{~Hz}, 3 \mathrm{H})$. 
${ }^{13} \mathrm{C}$ NMR $\left(75 \mathrm{MHz}, \mathrm{CDCl}_{3}\right): \delta=171.5\left(\mathrm{C}_{\mathrm{q}}\right), 166.2\left(\mathrm{C}_{\mathrm{q}}\right), 139.7(\mathrm{CH}), 135.7\left(\mathrm{C}_{\mathrm{q}}\right), 134.1\left(\mathrm{C}_{\mathrm{q}}\right), 132.6$ $(\mathrm{CH}), 132.4\left(\mathrm{C}_{\mathrm{q}}\right), 130.2(\mathrm{CH}), 127.0(\mathrm{CH}), 122.3(\mathrm{CH}), 64.8\left(\mathrm{CH}_{2}\right), 39.8\left(\mathrm{CH}_{2}\right), 30.7\left(\mathrm{CH}_{2}\right), 19.0$ $\left(\mathrm{CH}_{2}\right), 13.6\left(\mathrm{CH}_{3}\right)$.

IR (ATR): 2958, 1711, 1657, 1635, 1313, 1171, $976 \mathrm{~cm}^{-1}$.

MS (ESI) $m / z$ (relative intensity): $613(100)[2 \mathrm{M}+\mathrm{Na}]^{+}, 318(75)[\mathrm{M}+\mathrm{Na}]^{+}, 296(20)[\mathrm{M}+\mathrm{H}]^{+}$.

HR-MS (ESI) $m / z$ calcd for $\mathrm{C}_{15} \mathrm{H}_{19} \mathrm{ClNO}_{3}[\mathrm{M}+\mathrm{H}]^{+}:$296.1048, found: 296.1045 .<smiles>CCOC(=O)/C=C/c1cc(F)ccc1CC(N)=O</smiles>

\section{(E)-n-Butyl 3-[2-(2-amino-2-oxoethyl)-5-fluorophenyl]acrylate (133da):}

The general procedure $\mathbf{A}$ was followed using 2-(4-fluorophenyl)acetamide (132d) (76.5 mg, 0.50 mmol) and $n$-butyl acrylate (5a) (128 $\mathrm{mg}, 1.00 \mathrm{mmol})$. Isolation by column chromatography ( $n$-hexane/acetone: $3 / 1)$ yielded $133 d a(76.7 \mathrm{mg}, 55 \%)$ as a white solid.

M. p. $=127-128^{\circ} \mathrm{C}$.

${ }^{1}$ H NMR $\left(400 \mathrm{MHz}, \mathrm{CDCl}_{3}\right): \delta=7.81(\mathrm{~d}, J=15.8,1 \mathrm{H}), 7.30-7.25(\mathrm{~m}, 2 \mathrm{H}), 7.06(\mathrm{td}, J=8.2,2.7 \mathrm{~Hz}$, $1 \mathrm{H}), 6.35(\mathrm{~d}, J=15.8 \mathrm{~Hz}, 1 \mathrm{H}), 5.62(\mathrm{~s}, 1 \mathrm{H}), 5.44(\mathrm{~s}, 1 \mathrm{H}), 4.18(\mathrm{t}, J=6.7 \mathrm{~Hz}, 2 \mathrm{H}), 3.66(\mathrm{~s}, 2 \mathrm{H}), 1.70-$ $1.62(\mathrm{~m}, 2 \mathrm{H}), 1.45-1.35(\mathrm{~m}, 2 \mathrm{H}), 0.94(\mathrm{t}, J=7.4 \mathrm{~Hz}, 3 \mathrm{H})$.

${ }^{13} \mathbf{C ~ N M R}\left(100 \mathrm{MHz}, \mathrm{CDCl}_{3}\right): \delta=171.9\left(\mathrm{C}_{\mathrm{q}}\right), 166.3\left(\mathrm{C}_{\mathrm{q}}\right), 162.2\left(\mathrm{C}_{\mathrm{q}},{ }^{1} J_{\mathrm{C}-\mathrm{F}}=247.3 \mathrm{~Hz}\right), 139.9\left(\mathrm{CH},{ }^{4} J_{\mathrm{C}-}\right.$ $\mathrm{F}=2.3 \mathrm{~Hz}), 136.0\left(\mathrm{C}_{\mathrm{q}},{ }^{3} J_{\mathrm{C}-\mathrm{F}}=7.6 \mathrm{~Hz}\right), 133.0\left(\mathrm{CH},{ }^{3} J_{\mathrm{C}-\mathrm{F}}=8.2 \mathrm{~Hz}\right), 130.0\left(\mathrm{C}_{\mathrm{q}},{ }^{4} J_{\mathrm{C}-\mathrm{F}}=3.2 \mathrm{~Hz}\right), 122.2$ $(\mathrm{CH}), 117.3\left(\mathrm{CH},{ }^{2} J_{\mathrm{C}-\mathrm{F}}=21.5 \mathrm{~Hz}\right), 113.7\left(\mathrm{CH},{ }^{2} J_{\mathrm{C}-\mathrm{F}}=22.4 \mathrm{~Hz}\right), 64.7\left(\mathrm{CH}_{2}\right), 39.7\left(\mathrm{CH}_{2}\right), 30.7\left(\mathrm{CH}_{2}\right)$, $19.1\left(\mathrm{CH}_{2}\right), 13.7\left(\mathrm{CH}_{3}\right)$.

${ }^{19}$ F NMR $\left(376 \mathrm{~Hz}, \mathrm{CDCl}_{3}\right): \delta=-113.8$.

IR (ATR): 2956, 1703, 1674, 1492, 1268, 1175, $730 \mathrm{~cm}^{-1}$.

MS (ESI) $m / z$ (relative intensity): $581(100)[2 \mathrm{M}+\mathrm{Na}]^{+}, 302(40)[\mathrm{M}+\mathrm{Na}]^{+}, 280(25)[\mathrm{M}+\mathrm{H}]^{+}$.

HR-MS (ESI) $m / z$ calcd for $\mathrm{C}_{15} \mathrm{H}_{19} \mathrm{FNO}_{3}[\mathrm{M}+\mathrm{H}]^{+}:$280.1343, found: 280.1341 . 
<smiles>CCCOC(=O)/C=C/c1ccc(OC)cc1CC(N)=O</smiles>

\section{(E)-n-Butyl 3-[2-(2-amino-2-oxoethyl)-4-methylphenyl]acrylate (133ea):}

The general procedure $\mathbf{A}$ was followed using 2-( $m$-tolyl)acetamide (132e) $(74.5 \mathrm{mg}, 0.50 \mathrm{mmol})$ and $n$-butyl acrylate $(\mathbf{5 a})(128 \mathrm{mg}, 1.00 \mathrm{mmol})$. Isolation by column chromatography ( $n$-hexane/acetone: 3/1) yielded 133ea (78 $\mathrm{mg}, 58 \%$ ) as a white solid.

M. p. $=133-134{ }^{\circ} \mathrm{C}$

${ }^{1}$ H NMR (300 MHz, $\left.\mathrm{CDCl}_{3}\right): \delta=7.85(\mathrm{~d}, J=15.7 \mathrm{~Hz}, 1 \mathrm{H}), 7.51(\mathrm{~d}, J=7.9 \mathrm{~Hz}, 1 \mathrm{H}), 7.15-7.06(\mathrm{~m}, 2 \mathrm{H})$, $6.34(\mathrm{~d}, J=15.7 \mathrm{~Hz}, 1 \mathrm{H}), 5.47\left(\mathrm{~s}_{\mathrm{br}}, 1 \mathrm{H}\right), 5.35\left(\mathrm{~s}_{\mathrm{br}}, 1 \mathrm{H}\right), 4.18(\mathrm{t}, J=6.7 \mathrm{~Hz}, 2 \mathrm{H}), 3.68(\mathrm{~s}, 2 \mathrm{H}), 2.34(\mathrm{~s}$, $3 \mathrm{H}), 1.71-1.61(\mathrm{~m}, 2 \mathrm{H}), 1.47-1.34(\mathrm{~m}, 2 \mathrm{H}), 0.94(\mathrm{t}, J=7.3 \mathrm{~Hz}, 3 \mathrm{H})$.

${ }^{13} \mathrm{C}$ NMR $\left(125 \mathrm{MHz}, \mathrm{CDCl}_{3}\right): \delta=171.3\left(\mathrm{C}_{\mathrm{q}}\right), 165.9\left(\mathrm{C}_{\mathrm{q}}\right), 140.1\left(\mathrm{C}_{\mathrm{q}}\right), 139.9(\mathrm{CH}), 133.3\left(\mathrm{C}_{\mathrm{q}}\right), 131.2$ $(\mathrm{CH}), 130.3\left(\mathrm{C}_{\mathrm{q}}\right), 128.2(\mathrm{CH}), 126.4(\mathrm{CH}), 119.3(\mathrm{CH}), 63.8\left(\mathrm{CH}_{2}\right), 39.9\left(\mathrm{CH}_{2}\right), 30.1\left(\mathrm{CH}_{2}\right), 20.6$ $\left(\mathrm{CH}_{3}\right), 18.5\left(\mathrm{CH}_{2}\right), 13.1\left(\mathrm{CH}_{3}\right)$.

IR (ATR): 2959, 1700, 1666, 1313, 1176, 906, $729 \mathrm{~cm}^{-1}$.

MS (ESI) $m / z$ (relative intensity): $573(100)[2 \mathrm{M}+\mathrm{Na}]^{+}, 298(23)[\mathrm{M}+\mathrm{Na}]^{+}, 276(17)[\mathrm{M}+\mathrm{H}]^{+}$.

HR-MS (ESI) $m / z$ calcd for $\mathrm{C}_{16} \mathrm{H}_{22} \mathrm{NO}_{3}[\mathrm{M}+\mathrm{H}]^{+}:$276.1594, found: 276.1592 .<smiles>CCOC(=O)/C=C/c1ccc(OC)cc1CC(N)=O</smiles>

(E)-n-Butyl 3-[2-(2-amino-2-oxoethyl)-4-methoxyphenyl]acrylate (133fa):

The general procedure A was followed using 2-(3-methoxyphenyl)acetamide (132f) (82.5 mg, 0.50 mmol) and $n$-butyl acrylate (5a) (128 $\mathrm{mg}, 1.00 \mathrm{mmol})$. Isolation by column chromatography ( $n$-hexane/acetone: $3 / 1$ ) yielded $\mathbf{1 3 3 f a}$ (74 $\mathrm{mg}, 51 \%$ ) as a white solid.

M. p. $=123-124{ }^{\circ} \mathrm{C}$

${ }^{1}$ H NMR $\left(300 \mathrm{MHz}, \mathrm{CDCl}_{3}\right): \delta=7.84(\mathrm{~d}, J=15.7 \mathrm{~Hz}, 1 \mathrm{H}), 7.60(\mathrm{~d}, J=8.7 \mathrm{~Hz}, 1 \mathrm{H}), 6.89-6.80(\mathrm{~m}, 2 \mathrm{H})$, $6.30(\mathrm{~d}, J=15.7 \mathrm{~Hz}, 1 \mathrm{H}), 5.50\left(\mathrm{~s}_{\mathrm{br}}, 1 \mathrm{H}\right), 5.45\left(\mathrm{~s}_{\mathrm{br}}, 1 \mathrm{H}\right), 4.19(\mathrm{t}, J=6.7 \mathrm{~Hz}, 2 \mathrm{H}), 3.83(\mathrm{~s}, 3 \mathrm{H}), 3.71(\mathrm{~s}$, $2 \mathrm{H}), 1.73-1.63(\mathrm{~m}, 2 \mathrm{H}), 1.47-1.43(\mathrm{~m}, 2 \mathrm{H}), 0.96(\mathrm{t}, J=8.3 \mathrm{~Hz}, 3 \mathrm{H})$. 
${ }^{13}$ C NMR $\left(125 \mathrm{MHz}, \mathrm{CDCl}_{3}\right): \delta=171.1\left(\mathrm{C}_{\mathrm{q}}\right), 166.1\left(\mathrm{C}_{\mathrm{q}}\right), 160.4\left(\mathrm{C}_{\mathrm{q}}\right), 139.5(\mathrm{CH}), 135.2\left(\mathrm{C}_{\mathrm{q}}\right), 127.9$ $(\mathrm{CH}), 125.5\left(\mathrm{C}_{\mathrm{q}}\right), 117.7(\mathrm{CH}), 115.5(\mathrm{CH}), 113.2(\mathrm{CH}), 63.7\left(\mathrm{CH}_{2}\right), 54.7\left(\mathrm{CH}_{3}\right), 40.1\left(\mathrm{CH}_{2}\right), 30.1$ $\left(\mathrm{CH}_{2}\right), 18.5\left(\mathrm{CH}_{2}\right), 13.1\left(\mathrm{CH}_{3}\right)$.

MS (ESI) $m / z$ (relative intensity): $314(100)[\mathrm{M}+\mathrm{Na}]^{+}, 292(15)[\mathrm{M}+\mathrm{H}]^{+}$.

HR-MS (ESI) $m / z$ calcd for $\mathrm{C}_{16} \mathrm{H}_{22} \mathrm{NO}_{4}[\mathrm{M}+\mathrm{H}]^{+}: 292.1543$, found: 292.1541 .<smiles>CCCCOC(=O)C=Cc1cccc(OC)c1CC(N)=O</smiles>

\section{(E)-Butyl 3-(2-(2-amino-2-oxoethyl)-3-methylphenyl)acrylate (133ga):}

The general procedure A was followed using 2-(3-methoxyphenyl)acetamide (132g) (82.5 mg, 0.50 $\mathrm{mmol})$ and $n$-butyl acrylate (5a) (128 $\mathrm{mg}, 1.00 \mathrm{mmol})$. Isolation by column chromatography ( $n$-hexane/acetone: $3 / 1$ ) yielded 133ga (74 mg, $51 \%$ ) as a white solid.

M. p. $=120-121^{\circ} \mathrm{C}$.

${ }^{1} \mathbf{H}$ NMR $\left(300 \mathrm{MHz}, \mathrm{CDCl}_{3}\right): \delta=7.93(\mathrm{~d}, J=15.7 \mathrm{~Hz}, 1 \mathrm{H}), 7.43(\mathrm{dd}, J=6.7,2.4 \mathrm{~Hz}, 1 \mathrm{H}), 7.25-7.18$ $(\mathrm{m}, 2 \mathrm{H}), 6.33(\mathrm{~d}, J=15.7 \mathrm{~Hz}, 1 \mathrm{H}), 4.18(\mathrm{t}, J=6.7 \mathrm{~Hz}, 2 \mathrm{H}), 3.73(\mathrm{~s}, 2 \mathrm{H}), 2.34(\mathrm{~s}, 3 \mathrm{H}), 1.72-1.62(\mathrm{~m}$, $2 \mathrm{H}), 1.48-1.34(\mathrm{~m}, 2 \mathrm{H}), 0.94(\mathrm{t}, J=7.3 \mathrm{~Hz}, 3 \mathrm{H})$.

${ }^{13} \mathrm{C}$ NMR $\left(125 \mathrm{MHz}, \mathrm{CDCl}_{3}\right): \delta=171.8\left(\mathrm{C}_{\mathrm{q}}\right), 166.4\left(\mathrm{C}_{\mathrm{q}}\right), 141.7(\mathrm{CH}), 138.2\left(\mathrm{C}_{\mathrm{q}}\right), 134.6\left(\mathrm{C}_{\mathrm{q}}\right), 132.6$ $\left(\mathrm{C}_{\mathrm{q}}\right), 132.2(\mathrm{CH}), 127.8(\mathrm{CH}), 125.2(\mathrm{CH}), 121.6(\mathrm{CH}), 64.6\left(\mathrm{CH}_{2}\right), 36.9\left(\mathrm{CH}_{2}\right), 30.8\left(\mathrm{CH}_{2}\right), 20.3$ $\left(\mathrm{CH}_{3}\right), 19.3\left(\mathrm{CH}_{2}\right), 13.8\left(\mathrm{CH}_{3}\right)$.

IR (ATR): 2960, 1709, 1656, 1276, 1180, 909, $731 \mathrm{~cm}^{-1}$.

MS (ESI) $m / z$ (relative intensity): $573(100)[2 \mathrm{M}+\mathrm{Na}]^{+}, 298(50)[\mathrm{M}+\mathrm{Na}]^{+}, 276(20)[\mathrm{M}+\mathrm{H}]^{+}$.

HR-MS (ESI) $m / z$ calcd for $\mathrm{C}_{16} \mathrm{H}_{22} \mathrm{NO}_{3}[\mathrm{M}+\mathrm{H}]+:$ 276.1594, found: 276.1592 . 
<smiles>COC(C)=O</smiles>

\section{(E)-Methyl 3-[2-(2-amino-2-oxoethyl)-5-chlorophenyl]acrylate (133cc):}

The general procedure $\mathbf{A}$ was followed using 2-(4-chlorophenyl)acetamide (132c) (84.5 mg, 0.50 mmol) and methyl acrylate $(\mathbf{5 c})(86 \mathrm{mg}, 1.00 \mathrm{mmol})$. Isolation by column chromatography ( $n$-hexane/acetone: $3 / 1)$ yielded 133cc (66 mg, 52\%) as a white solid.

M. p. $=133-134{ }^{\circ} \mathrm{C}$.

${ }^{1}$ H NMR $\left(500 \mathrm{MHz}, \mathrm{CDCl}_{3}\right): \delta=7.81(\mathrm{~d}, J=15.8 \mathrm{~Hz}, 1 \mathrm{H}), 7.56(\mathrm{~d}, J=2.1 \mathrm{~Hz}, 1 \mathrm{H}), 7.33(\mathrm{dd}, J=8.2$, $2.2 \mathrm{~Hz}, 1 \mathrm{H}), 7.23(\mathrm{~d}, J=8.3 \mathrm{~Hz}, 1 \mathrm{H}), 6.36(\mathrm{~d}, J=15.8 \mathrm{~Hz}, 1 \mathrm{H}), 5.51\left(\mathrm{~s}_{\mathrm{br}}, 1 \mathrm{H}\right), 5.40\left(\mathrm{~s}_{\mathrm{br}}, 1 \mathrm{H}\right), 3.79(\mathrm{~s}$, $3 \mathrm{H}), 3.66(\mathrm{~s}, 2 \mathrm{H})$.

${ }^{13} \mathrm{C}$ NMR $\left(125 \mathrm{MHz}, \mathrm{CDCl}_{3}\right): \delta=171.0\left(\mathrm{C}_{\mathrm{q}}\right), 166.0\left(\mathrm{C}_{\mathrm{q}}\right), 139.4(\mathrm{CH}), 135.1\left(\mathrm{C}_{\mathrm{q}}\right), 133.5\left(\mathrm{C}_{\mathrm{q}}\right), 132.0$ $(\mathrm{CH}), 131.9\left(\mathrm{C}_{\mathrm{q}}\right), 129.7(\mathrm{CH}), 126.5(\mathrm{CH}), 121.3(\mathrm{CH}), 51.4\left(\mathrm{CH}_{3}\right), 39.3\left(\mathrm{CH}_{2}\right)$.

IR (ATR): 2953, 1712, 1669, 1312, 1169, 973, $697 \mathrm{~cm}^{-1}$.

MS (ESI) $m / z$ (relative intensity): $529(100)[2 \mathrm{M}+\mathrm{Na}]^{+}, 276(50)[\mathrm{M}+\mathrm{Na}]^{+}, 254(20)[\mathrm{M}+\mathrm{H}]^{+}$.

HR-MS (ESI) $m / z$ calcd for $\mathrm{C}_{12} \mathrm{H}_{13} \mathrm{ClNO}_{3}[\mathrm{M}+\mathrm{H}]^{+}: 254.0516$, found: 254.0519 .<smiles>NC(=O)Cc1ccc(Cl)cc1/C=C/C(=O)OCc1ccccc1</smiles>

\section{(E)-Benzyl 3-[2-(2-amino-2-oxoethyl)-5-chlorophenyl]acrylate (133cd):}

The general procedure A was followed using 2-(4-chlorophenyl)acetamide (132c) $(84.5 \mathrm{mg}, 0.50$ mmol) and benzyl acrylate (5d) (162 $\mathrm{mg}, 1.00 \mathrm{mmol})$. Isolation by column chromatography ( $n$-hexane/acetone: $3 / 1)$ yielded 133cd (105 mg, 64\%) as a white solid.

M. p. $=165-166^{\circ} \mathrm{C}$. 
${ }^{1}$ H NMR (300 MHz, $\left.\mathrm{CDCl}_{3}\right): \delta=7.85(\mathrm{~d}, J=15.8 \mathrm{~Hz}, 1 \mathrm{H}), 7.56(\mathrm{~d}, J=2.2 \mathrm{~Hz}, 1 \mathrm{H}), 7.40-7.35(\mathrm{~m}, 3 \mathrm{H})$, 7.35-7.30 (m, 2H), 7.24-7.20 (m, 2H), $6.41(\mathrm{~d}, J=15.8 \mathrm{~Hz}, 1 \mathrm{H}), 5.46\left(\mathrm{~s}_{\mathrm{br}}, 1 \mathrm{H}\right), 5.40\left(\mathrm{~s}_{\mathrm{br}}, 1 \mathrm{H}\right), 5.23(\mathrm{~s}$, $2 \mathrm{H}), 3.65(\mathrm{~s}, 2 \mathrm{H})$.

${ }^{13}$ C NMR $\left(125 \mathrm{MHz}, \mathrm{CDCl}_{3}\right): \delta=171.3\left(\mathrm{C}_{\mathrm{q}}\right), 165.9\left(\mathrm{C}_{\mathrm{q}}\right), 140.2(\mathrm{CH}), 135.7\left(\mathrm{C}_{\mathrm{q}}\right), 135.5\left(\mathrm{C}_{\mathrm{q}}\right), 134.0$ $\left(\mathrm{C}_{\mathrm{q}}\right), 132.5(\mathrm{CH}), 132.4\left(\mathrm{C}_{\mathrm{q}}\right), 130.2(\mathrm{CH}), 128.5(\mathrm{CH}), 128.3(\mathrm{CH}), 128.2(\mathrm{CH}), 127.0(\mathrm{CH}), 121.8$ $(\mathrm{CH}), 66.7\left(\mathrm{CH}_{2}\right), 39.8\left(\mathrm{CH}_{2}\right)$.

IR (ATR): 2940, 1710, 1669, 1635, 1312, 1168, $697 \mathrm{~cm}^{-1}$.

MS (ESI) $m / z$ (relative intensity): $352(100)[\mathrm{M}+\mathrm{Na}]^{+}, 330(20)[\mathrm{M}+\mathrm{H}]^{+}$.

HR-MS (ESI) $m / z$ calcd for $\mathrm{C}_{18} \mathrm{H}_{17} \mathrm{ClNO}_{3}[\mathrm{M}+\mathrm{H}]^{+}: 330.0891$, found: 330.0888 .<smiles>CCOC(=O)/C=C/c1ccccc1CC(N)=O</smiles>

\section{(E)-Ethyl 3-[2-(2-amino-2-oxoethyl)phenyl]acrylate (133ab):}

The general procedure $\mathbf{A}$ was followed using 2-phenylacetamide (132a) (67.5 mg, $0.50 \mathrm{mmol})$ and ethyl acrylate (5b) (100 mg, $1.00 \mathrm{mmol})$. Isolation by column chromatography ( $n$-hexane/acetone: $3 / 1)$ yielded 133ab (83 $\mathrm{mg}, 71 \%$ ) as a white solid.

M. p. $=101-103{ }^{\circ} \mathrm{C}$.

${ }^{1}$ H NMR $\left(400 \mathrm{MHz}, \mathrm{CDCl}_{3}\right): \delta=7.91(\mathrm{~d}, J=15.7 \mathrm{~Hz}, 1 \mathrm{H}), 7.62(\mathrm{dd}, J=7.5,1.6 \mathrm{~Hz}, 1 \mathrm{H}), 7.40-7.28$ $(\mathrm{m}, 3 \mathrm{H}), 6.38(\mathrm{~d}, J=15.7 \mathrm{~Hz}, 1 \mathrm{H}), 5.53\left(\mathrm{~s}_{\mathrm{br}}, 1 \mathrm{H}\right), 5.40\left(\mathrm{~s}_{\mathrm{br}}, 1 \mathrm{H}\right), 4.26(\mathrm{q}, J=7.1 \mathrm{~Hz}, 2 \mathrm{H}), 3.73(\mathrm{~s}, 2 \mathrm{H})$, $1.33(\mathrm{t}, J=7.1 \mathrm{~Hz}, 3 \mathrm{H})$.

${ }^{13} \mathrm{C}$ NMR $\left(100 \mathrm{MHz}, \mathrm{CDCl}_{3}\right): \delta=171.2\left(\mathrm{C}_{\mathrm{q}}\right), 165.6\left(\mathrm{C}_{\mathrm{q}}\right), 139.9(\mathrm{CH}), 133.1\left(\mathrm{C}_{\mathrm{q}}\right), 133.1\left(\mathrm{C}_{\mathrm{q}}\right), 130.3$ $(\mathrm{CH}), 129.5(\mathrm{CH}), 127.2(\mathrm{CH}), 126.3(\mathrm{CH}), 120.2(\mathrm{CH}), 59.7\left(\mathrm{CH}_{2}\right), 39.6\left(\mathrm{CH}_{2}\right), 13.3\left(\mathrm{CH}_{3}\right)$.

IR (ATR): 2934, 1714, 1667, 1633, 1315, 1179, $766 \mathrm{~cm}^{-1}$.

MS (ESI) $m / z$ (relative intensity): $489(100)[2 \mathrm{M}+\mathrm{Na}]^{+}, 256(65)[\mathrm{M}+\mathrm{Na}]^{+}, 234(25)[\mathrm{M}+\mathrm{H}]^{+}$.

HR-MS (ESI) $m / z$ calcd for $\mathrm{C}_{13} \mathrm{H}_{16} \mathrm{NO}_{3}[\mathrm{M}+\mathrm{H}]^{+}: 234.1125$, found: 234.1123 . 
<smiles>NC(=O)Cc1ccccc1/C=C/C(=O)Oc1ccccc1</smiles>

\section{(E)-Phenyl 3-[2-(2-amino-2-oxoethyl)phenyl]acrylate (133ae):}

The general procedure $\mathbf{A}$ was followed using 2-phenylacetamide (132a) (67.5 mg, $0.50 \mathrm{mmol}$ ) and phenyl acrylate $(\mathbf{5 e})(128 \mathrm{mg}, 1.00 \mathrm{mmol})$. Isolation by column chromatography ( $n$-hexane/acetone: 3/1) yielded 133ae (79 $\mathrm{mg}, 56 \%$ ) as a white solid.

M. p. $=153-154{ }^{\circ} \mathrm{C}$.

${ }^{1}$ H NMR $\left(300 \mathrm{MHz}, \mathrm{CDCl}_{3}\right): \delta=8.09(\mathrm{~d}, J=15.7 \mathrm{~Hz}, 1 \mathrm{H}), 7.68(\mathrm{dd}, J=7.3,1.8 \mathrm{~Hz}, 1 \mathrm{H}), 7.44-7.29$ $(\mathrm{m}, 5 \mathrm{H}), 7.24-7.20(\mathrm{~m}, 1 \mathrm{H}), 7.18-7.12(\mathrm{~m}, 2 \mathrm{H}), 6.57(\mathrm{~d}, J=15.7 \mathrm{~Hz}, 1 \mathrm{H}), 5.56\left(\mathrm{~s}_{\mathrm{br}}, 1 \mathrm{H}\right), 5.44\left(\mathrm{~s}_{\mathrm{br}}, 1 \mathrm{H}\right)$, $3.74(\mathrm{~s}, 2 \mathrm{H})$.

${ }^{13} \mathrm{C}$ NMR $\left(125 \mathrm{MHz}, \mathrm{CDCl}_{3}\right): \delta=171.9\left(\mathrm{C}_{\mathrm{q}}\right), 164.8\left(\mathrm{C}_{\mathrm{q}}\right), 150.6\left(\mathrm{C}_{\mathrm{q}}\right), 142.8(\mathrm{CH}), 134.4\left(\mathrm{C}_{\mathrm{q}}\right), 133.7$ $\left(\mathrm{C}_{\mathrm{q}}\right), 131.3(\mathrm{CH}), 130.8(\mathrm{CH}), 129.3(\mathrm{CH}), 128.4(\mathrm{CH}), 127.3(\mathrm{CH}), 125.8(\mathrm{CH}), 121.5(\mathrm{CH}), 120.0$ $(\mathrm{CH}), 40.6\left(\mathrm{CH}_{2}\right)$.

IR (ATR): 3182, 1722, 1661, 1631, 1483, 1142, $975 \mathrm{~cm}^{-1}$.

MS (ESI) $m / z$ (relative intensity): $585(100)[2 \mathrm{M}+\mathrm{Na}]^{+}, 304(55)[\mathrm{M}+\mathrm{Na}]^{+}, 282(4)[\mathrm{M}+\mathrm{H}]^{+}$.

HR-MS (ESI) $m / z$ calcd for $\mathrm{C}_{17} \mathrm{H}_{16} \mathrm{NO}_{3}[\mathrm{M}+\mathrm{H}]^{+}: 282.1125$, found: 282.1123 .<smiles>NC(=O)Cc1ccccc1/C=C/C(=O)Oc1ccc2ccccc2c1</smiles>

\section{(E)-naphthalen-2-yl 3-(2-(2-amino-2-oxoethyl)phenyl)acrylate (133af):}

The general procedure $\mathbf{A}$ was followed using 2-phenylacetamide (132a) (67.5 $\mathrm{mg}, 0.50 \mathrm{mmol}$ ) and phenyl acrylate $\mathbf{( 5 f})(128 \mathrm{mg}, 1.00 \mathrm{mmol})$. Isolation by column chromatography ( $n$-hexane/acetone: 3/1) yielded 133af (79 $\mathrm{mg}, 56 \%)$ as a white solid.

M. p. $=158-159^{\circ} \mathrm{C}$.

${ }^{1}$ H NMR $\left(300 \mathrm{MHz}, \mathrm{CDCl}_{3}\right): \delta=8.13(\mathrm{~d}, J=15.7 \mathrm{~Hz}, 1 \mathrm{H}), 7.89-7.78(\mathrm{~m}, 3 \mathrm{H}), 7.73-7.68(\mathrm{~m}, 1 \mathrm{H})$, $7.63(\mathrm{~d}, J=2.3 \mathrm{~Hz}, 1 \mathrm{H}), 7.52-7.44(\mathrm{~m}, 2 \mathrm{H}), 7.44-7.36(\mathrm{~m}, 2 \mathrm{H}), 7.34-7.27(\mathrm{~m}, 2 \mathrm{H}), 6.62(\mathrm{~d}, J=15.7$ $\mathrm{Hz}, 1 \mathrm{H}), 3.75$ (s, 2H). 
${ }^{13}$ C NMR (125 MHz, $\left.\mathrm{CDCl}_{3}\right): \delta=170.8\left(\mathrm{C}_{\mathrm{q}}\right), 164.0\left(\mathrm{C}_{\mathrm{q}}\right), 147.3\left(\mathrm{C}_{\mathrm{q}}\right), 142.0(\mathrm{CH}), 133.4\left(\mathrm{C}_{\mathrm{q}}\right), 132.7$ $\left(\mathrm{C}_{\mathrm{q}}\right), 132.7\left(\mathrm{C}_{\mathrm{q}}\right), 130.4\left(\mathrm{C}_{\mathrm{q}}\right), 130.3(\mathrm{CH}), 129.8(\mathrm{CH}), 128.3(\mathrm{CH}), 127.2(\mathrm{CH}), 126.7(\mathrm{CH}), 126.6(\mathrm{CH})$, $126.3(\mathrm{CH}), 125.5(\mathrm{CH}), 124.6(\mathrm{CH}), 120.1(\mathrm{CH}), 119.0(\mathrm{CH}), 117.5(\mathrm{CH}), 39.7\left(\mathrm{CH}_{2}\right)$.

IR (ATR): 2924, 1724, 1667, 1598, 1214, 1142, $760 \mathrm{~cm}^{-1}$.

MS (ESI) $m / z$ (relative intensity): $685(100)[2 \mathrm{M}+\mathrm{Na}]^{+}, 354(52)[\mathrm{M}+\mathrm{Na}]^{+}, 332(6)[\mathrm{M}+\mathrm{H}]^{+}$.

HR-MS (ESI) $m / z$ calcd for $\mathrm{C}_{21} \mathrm{H}_{18} \mathrm{NO}_{3}[\mathrm{M}+\mathrm{H}]^{+}: 332.1281$, found: 332.1278 .<smiles>CCOC(=O)/C=C/c1ccc2ccccc2c1CC(N)=O</smiles>

\section{(E)-n-Butyl 3-[1-(2-amino-2-oxoethyl)naphthalen-2-yl]acrylate (133ha):}

The general procedure A was followed using 2-(naphthalen-1-yl)acetamide (132h) (92.5 mg, 0.50 $\mathrm{mmol}$ ) and $n$-butyl acrylate (5a) (128 $\mathrm{mg}, 1.00 \mathrm{mmol})$. Isolation by column chromatography (n-hexane/aceton: $3 / 1)$ yielded $\mathbf{1 3 3 h a}(110 \mathrm{mg}, 71 \%)$ as a white solid.

M. p. $=156-157{ }^{\circ} \mathrm{C} .{ }^{1} \mathrm{H}$ NMR $\left(400 \mathrm{MHz}, \mathrm{CDCl}_{3}\right): \delta=8.19(\mathrm{~d}, J=15.7 \mathrm{~Hz}, 1 \mathrm{H}), 8.08(\mathrm{~d}, J=8.3 \mathrm{~Hz}$, $1 \mathrm{H}), 7.85(\mathrm{t}, J=8.8 \mathrm{~Hz}, 2 \mathrm{H}), 7.70(\mathrm{~d}, J=8.7 \mathrm{~Hz}, 1 \mathrm{H}), 7.65-7.50(\mathrm{~m}, 2 \mathrm{H}), 6.52(\mathrm{~d}, J=15.7 \mathrm{~Hz}, 1 \mathrm{H})$, $5.42\left(\mathrm{~s}_{\mathrm{br}}, 1 \mathrm{H}\right), 5.24\left(\mathrm{~s}_{\mathrm{br}}, 1 \mathrm{H}\right), 4.27-4.22(\mathrm{~m}, 4 \mathrm{H}), 1.76-1.66(\mathrm{~m}, 2 \mathrm{H}), 1.44(\mathrm{dt}, J=13.6,6.8 \mathrm{~Hz}, 2 \mathrm{H})$, $0.98(\mathrm{t}, J=7.3 \mathrm{~Hz}, 3 \mathrm{H})$.

${ }^{13} \mathrm{C}$ NMR $\left(100 \mathrm{MHz}, \mathrm{CDCl}_{3}\right): \delta=171.0\left(\mathrm{C}_{\mathrm{q}}\right), 165.6\left(\mathrm{C}_{\mathrm{q}}\right), 140.2(\mathrm{CH}), 133.3\left(\mathrm{C}_{\mathrm{q}}\right), 131.5\left(\mathrm{C}_{\mathrm{q}}\right), 130.7$ $\left(\mathrm{C}_{\mathrm{q}}\right), 129.8\left(\mathrm{C}_{\mathrm{q}}\right), 127.9(\mathrm{CH}), 127.8(\mathrm{CH}), 126.7(\mathrm{CH}), 126.2(\mathrm{CH}), 123.5(\mathrm{CH}), 122.9(\mathrm{CH}), 121.2$ $(\mathrm{CH}), 63.8\left(\mathrm{CH}_{2}\right), 35.3\left(\mathrm{CH}_{2}\right), 29.7\left(\mathrm{CH}_{2}\right), 18.2\left(\mathrm{CH}_{2}\right), 12.7\left(\mathrm{CH}_{3}\right)$.

IR (ATR): 2957, 1644, 1626, 1380, 1259, 1175, 1164, $792 \mathrm{~cm}^{-1}$. MS (ESI) $\mathrm{m} / \mathrm{z}$ (relative intensity): 645 (68) $[2 \mathrm{M}+\mathrm{Na}]^{+}, 334(100)[\mathrm{M}+\mathrm{Na}]^{+}, 312(24)[\mathrm{M}+\mathrm{H}]^{+}$.

HR-MS (ESI) $m / z$ calcd for $\mathrm{C}_{19} \mathrm{H}_{22} \mathrm{NO}_{3}[\mathrm{M}+\mathrm{H}]^{+}: 312.1594$, found: 312.1590 . 
<smiles>NC(=O)Cc1ccccc1/C=C/S(=O)(=O)c1ccccc1</smiles>

\section{(E)-2-\{2-[2-(Phenylsulfonyl)vinyl]phenyl\}acetamide (133ag):}

The general procedure $\mathbf{A}$ was followed using 2-phenylacetamide (132a) $(67.5 \mathrm{mg}, 0.50 \mathrm{mmol})$ and (vinylsulfonyl)benzene $(\mathbf{5 g})(168 \mathrm{mg}, 1.00 \mathrm{mmol})$. Isolation by column chromatography ( $n$-hexane/acetone: $3 / 1$ ) yielded 133ag (95 mg, 61\%) as a yellow solid.

M. p. $=135-136^{\circ} \mathrm{C}$

${ }^{1} \mathrm{H}$ NMR $\left(300 \mathrm{MHz}, \mathrm{CDCl}_{3}\right): \delta=7.96-7.87(\mathrm{~m}, 3 \mathrm{H}), 7.63-7.47(\mathrm{~m}, 4 \mathrm{H}), 7.42-7.26(\mathrm{~m}, 3 \mathrm{H}), 6.80(\mathrm{~d}, J$ $=15.2 \mathrm{~Hz}, 1 \mathrm{H}), 5.44\left(\mathrm{~s}_{\mathrm{br}}, 2 \mathrm{H}\right), 3.72(\mathrm{~s}, 2 \mathrm{H})$.

${ }^{13}$ C NMR $\left(125 \mathrm{MHz}, \mathrm{CDCl}_{3}\right): \delta=171.4\left(\mathrm{C}_{\mathrm{q}}\right), 140.3\left(\mathrm{C}_{\mathrm{q}}\right), 139.3(\mathrm{CH}), 134.6\left(\mathrm{C}_{\mathrm{q}}\right), 133.4(\mathrm{CH}), 132.0$ $\left(\mathrm{C}_{\mathrm{q}}\right), 131.4(\mathrm{CH}), 131.2(\mathrm{CH}), 129.7(\mathrm{CH}), 129.3(\mathrm{CH}), 128.2(\mathrm{CH}), 127.7(\mathrm{CH}), 127.5(\mathrm{CH}), 40.6$ $\left(\mathrm{CH}_{2}\right)$.

IR (ATR): 1670, 1303, 1144, 1084, 752, 687, $541 \mathrm{~cm}^{-1}$.

MS (ESI) $m / z$ (relative intensity): $625(100)[2 \mathrm{M}+\mathrm{Na}]^{+}, 324(73)[\mathrm{M}+\mathrm{Na}]^{+}, 302(13)[\mathrm{M}+\mathrm{H}]^{+}$.

HR-MS (ESI) $m / z$ calcd for $\mathrm{C}_{16} \mathrm{H}_{16} \mathrm{NO}_{3} \mathrm{~S}[\mathrm{M}+\mathrm{H}]^{+}:$302.0845, found: 302.0841 .

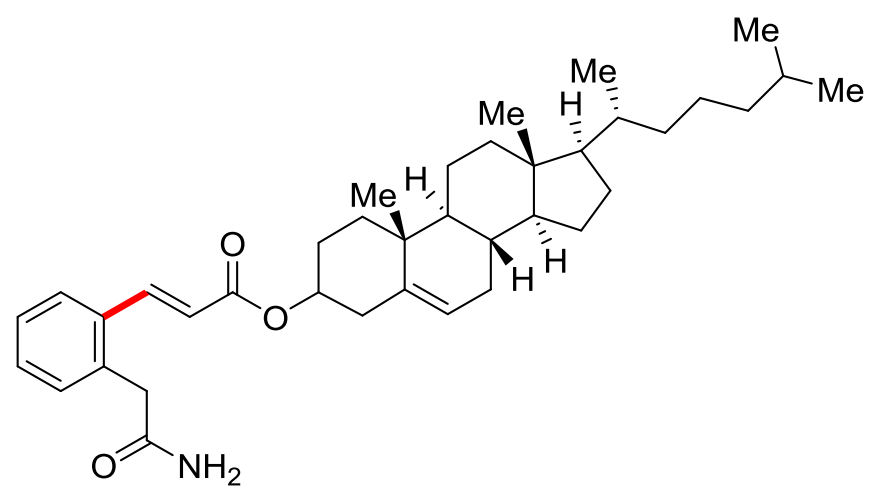

\section{(E)-Cholesteryl [2-(2-amino-2-oxoethyl)phenyl]acrylate (133ah):}

The general procedure A was followed using 2-phenylacetamide (132a) $(67.5 \mathrm{mg}, 0.50 \mathrm{mmol})$ and cholesteryl acrylate $(\mathbf{5 h})(440 \mathrm{mg}, 1.00 \mathrm{mmol})$ in 1,4-dioxane $(1.8 \mathrm{~mL})$ and $\mathrm{PhMe}(0.2 \mathrm{~mL})$ at $120{ }^{\circ} \mathrm{C}$. 
Isolation by column chromatography ( $n$-hexane/acetone: $3 / 1)$ yielded 133ah $(163 \mathrm{mg}, 57 \%)$ as a white solid.

M. $\mathbf{p .}=127-128^{\circ} \mathrm{C}$

${ }^{1}$ H NMR $\left(300 \mathrm{MHz}, \mathrm{CDCl}_{3}\right): \delta=7.88(\mathrm{~d}, J=15.8 \mathrm{~Hz}, 1 \mathrm{H}), 7.59(\mathrm{dd}, J=7.6,1.4 \mathrm{~Hz}, 1 \mathrm{H}), 7.38-7.25$ $(\mathrm{m}, 3 \mathrm{H}), 6.35(\mathrm{~d}, J=15.8 \mathrm{~Hz}, 1 \mathrm{H}), 5.64\left(\mathrm{~s}_{\mathrm{br}}, 1 \mathrm{H}\right), 5.45\left(\mathrm{~s}_{\mathrm{br}}, 1 \mathrm{H}\right), 5.40-5.34(\mathrm{~m}, 1 \mathrm{H}), 4.78-4.64(\mathrm{~m}, 1 \mathrm{H})$, 3.69 (s, 2H), 2.37 (d, $J=7.8 \mathrm{~Hz}, 2 \mathrm{H}), 2.08-0.94$ (m, 29H), 0.90 (d, $J=6.5 \mathrm{~Hz}, 3 \mathrm{H}), 0.85$ (dd, $J=6.6$, $1.3 \mathrm{~Hz}, 6 \mathrm{H}), 0.67$ (s, 3H).

${ }^{13}$ C NMR (100 MHz, $\left.\mathrm{CDCl}_{3}\right): \delta=172.5\left(\mathrm{C}_{\mathrm{q}}\right), 166.0\left(\mathrm{C}_{\mathrm{q}}\right), 140.9(\mathrm{CH}), 139.6\left(\mathrm{C}_{\mathrm{q}}\right), 134.2\left(\mathrm{C}_{\mathrm{q}}\right), 134.1$ $\left(\mathrm{C}_{\mathrm{q}}\right), 131.3(\mathrm{CH}), 130.4(\mathrm{CH}), 128.1(\mathrm{CH}), 127.2(\mathrm{CH}), 122.7(\mathrm{CH}), 121.4(\mathrm{CH}), 74.3(\mathrm{CH}), 56.7(\mathrm{CH})$, 56.1 (CH), $50.0(\mathrm{CH}), 42.3\left(\mathrm{C}_{\mathrm{q}}\right), 40.5\left(\mathrm{CH}_{2}\right), 39.7\left(\mathrm{CH}_{2}\right), 39.5\left(\mathrm{CH}_{2}\right), 38.2\left(\mathrm{CH}_{2}\right), 37.0\left(\mathrm{CH}_{2}\right), 36.6\left(\mathrm{C}_{\mathrm{q}}\right)$, $36.2\left(\mathrm{CH}_{2}\right), 35.8(\mathrm{CH}), 31.9\left(\mathrm{CH}_{2}\right), 31.8(\mathrm{CH}), 28.2\left(\mathrm{CH}_{2}\right), 28.0(\mathrm{CH}), 27.8\left(\mathrm{CH}_{2}\right), 24.3\left(\mathrm{CH}_{2}\right), 23.8$ $\left(\mathrm{CH}_{2}\right), 22.8\left(\mathrm{CH}_{3}\right), 22.5\left(\mathrm{CH}_{3}\right), 21.0\left(\mathrm{CH}_{2}\right), 19.3\left(\mathrm{CH}_{3}\right), 18.7\left(\mathrm{CH}_{3}\right), 11.8\left(\mathrm{CH}_{3}\right)$.

IR (ATR): 2936, 1667, 1320, 1171, 907, 765, 731, $593 \mathrm{~cm}^{-1}$. MS (ESI) $\mathrm{m} / \mathrm{z}$ (relative intensity): 1169 (100) $[2 \mathrm{M}+\mathrm{Na}]^{+}, 596(70)[\mathrm{M}+\mathrm{Na}]^{+}, 574(12)[\mathrm{M}+\mathrm{H}]^{+}$.

HR-MS (ESI) $m / z$ calcd for $\mathrm{C}_{38} \mathrm{H}_{56} \mathrm{NO}_{3}[\mathrm{M}+\mathrm{H}]^{+}:$: 574.4255, found: 574.4249 .<smiles>CCOC(=O)/C=C/c1ccccc1CC(=O)NC(C)(C)C</smiles>

(E)-n-Butyl 3-\{2-[2-(tert-butylamino)-2-oxoethyl]phenyl\}acrylate (133ia):

The general procedure A was followed using $N$-(tert-butyl)-2-phenylacetamide (132i) (95.5 mg, 0.50 mmol) and $n$-butyl acrylate $(\mathbf{5 a})(128 \mathrm{mg}, 1.00 \mathrm{mmol})$. Isolation by column chromatography ( $n$-hexane/EtOAc: $5 / 1$ ) yielded 133ia (133 mg, 84\%) as a white solid.

M. p. $=142-143^{\circ} \mathrm{C}$.

${ }^{1} \mathbf{H}$ NMR $\left(300 \mathrm{MHz}, \mathrm{CDCl}_{3}\right): \delta=7.86(\mathrm{~d}, J=15.8 \mathrm{~Hz}, 1 \mathrm{H}), 7.58(\mathrm{dd}, J=7.4,1.7 \mathrm{~Hz}, 1 \mathrm{H}), 7.37-7.23$ $(\mathrm{m}, 3 \mathrm{H}), 6.35(\mathrm{~d}, J=15.8 \mathrm{~Hz}, 1 \mathrm{H}), 5.15(\mathrm{~s} \mathrm{br}, 1 \mathrm{H}), 4.19(\mathrm{t}, J=6.7 \mathrm{~Hz}, 2 \mathrm{H}), 3.60(\mathrm{~s}, 2 \mathrm{H}), 1.71-1.61(\mathrm{~m}$, 2H), 1.47-1.36 (m, 2H), 1.25 (s, 9H), 0.94 (t, $J=8.4 \mathrm{~Hz}, 3 \mathrm{H})$. 
${ }^{13}$ C NMR (125 MHz, $\left.\mathrm{CDCl}_{3}\right): \delta=168.8\left(\mathrm{C}_{\mathrm{q}}\right), 166.4\left(\mathrm{C}_{\mathrm{q}}\right), 141.2(\mathrm{CH}), 134.7\left(\mathrm{C}_{\mathrm{q}}\right), 133.9\left(\mathrm{C}_{\mathrm{q}}\right), 131.2$ $(\mathrm{CH}), 130.3(\mathrm{CH}), 127.8(\mathrm{CH}), 127.0(\mathrm{CH}), 120.8(\mathrm{CH}), 64.5\left(\mathrm{CH}_{2}\right), 51.4\left(\mathrm{C}_{\mathrm{q}}\right), 42.4\left(\mathrm{CH}_{2}\right), 30.8\left(\mathrm{CH}_{2}\right)$, $28.7\left(\mathrm{CH}_{2}\right), 19.3\left(\mathrm{CH}_{3}\right), 13.8\left(\mathrm{CH}_{3}\right)$.

IR (ATR): 2961, 1710, 1636, 1547, 1358, 1167, $762 \mathrm{~cm}^{-1}$. MS (ESI) $\mathrm{m} / z$ (relative intensity): 340 (60) $[\mathrm{M}+\mathrm{Na}]^{+}, 318(100)[\mathrm{M}+\mathrm{H}]^{+}$.

HR-MS (ESI) $m / z$ calcd for $\mathrm{C}_{19} \mathrm{H}_{28} \mathrm{NO}_{3}[\mathrm{M}+\mathrm{H}]^{+}: 318.2064$, found: 318.2063.<smiles>COC(=O)/C=C/c1ccccc1CC(=O)NC(C)(C)C</smiles>

\section{(E)-Methyl 3-\{2[2-(tert-butylamino)-2-oxoethyl]phenyl\}acrylate (133ic):}

The general procedure A was followed using $N$-(tert-butyl)-2-phenylacetamide (132i) $(95.5 \mathrm{mg}, 0.50$ mmol) and methyl acrylate (5c) $(86 \mathrm{mg}, 1.00 \mathrm{mmol})$. Isolation by column chromatography (n-hexane/EtOAc: $5 / 1)$ yielded 133ic (118 $\mathrm{mg}, 86 \%)$ as a white solid.

M. p. $=135-136^{\circ} \mathrm{C}$.

${ }^{1} \mathbf{H}$ NMR $\left(400 \mathrm{MHz}, \mathrm{CDCl}_{3}\right): \delta=7.88(\mathrm{~d}, J=15.8 \mathrm{~Hz}, 1 \mathrm{H}), 7.58(\mathrm{dd}, J=7.6,1.5 \mathrm{~Hz}, 1 \mathrm{H}), 7.37-7.24$ $(\mathrm{m}, 3 \mathrm{H}), 6.35(\mathrm{~d}, J=15.8 \mathrm{~Hz}, 1 \mathrm{H}), 5.17(\mathrm{~s} \mathrm{br}, 1 \mathrm{H}), 3.78(\mathrm{~s}, 3 \mathrm{H}), 3.60(\mathrm{~s}, 2 \mathrm{H}), 1.25(\mathrm{~s}, 9 \mathrm{H})$.

${ }^{13} \mathrm{C}$ NMR $\left(100 \mathrm{MHz}, \mathrm{CDCl}_{3}\right): \delta=168.1\left(\mathrm{C}_{\mathrm{q}}\right), 166.0\left(\mathrm{C}_{\mathrm{q}}\right), 140.6(\mathrm{CH}), 133.8\left(\mathrm{C}_{\mathrm{q}}\right), 132.9\left(\mathrm{C}_{\mathrm{q}}\right), 130.3$ $(\mathrm{CH}), 129.4(\mathrm{CH}), 126.9(\mathrm{CH}), 126.1(\mathrm{CH}), 119.3(\mathrm{CH}), 50.8\left(\mathrm{CH}_{3}\right), 50.5\left(\mathrm{C}_{\mathrm{q}}\right), 41.4\left(\mathrm{CH}_{2}\right), 27.6\left(\mathrm{CH}_{3}\right)$. IR (ATR): 2925, 1711, 1646, 1545, 1318, 1170, $765 \mathrm{~cm}^{-1}$.

MS (ESI) $m / z$ (relative intensity): $298(100)[\mathrm{M}+\mathrm{Na}]^{+}, 276(30)[\mathrm{M}+\mathrm{H}]^{+}, 244(20)$.

HR-MS (ESI) $m / z$ calcd for $\mathrm{C}_{16} \mathrm{H}_{22} \mathrm{NO}_{3}[\mathrm{M}+\mathrm{H}]^{+}:$276.1594, found: 276.1596. 
<smiles>CCCCNC(=O)Cc1ccccc1/C=C/C(=O)OC</smiles>

\section{(E)-Methyl 3-\{2-[2-(n-butylamino)-2-oxoethyl]phenyl\}acrylate (133jc):}

The general procedure A was followed using $N$ - $n$-butyl-2-phenylacetamide (132j) $(95.5 \mathrm{mg}, 0.50$ mmol) and methyl acrylate $(\mathbf{5 c})(86 \mathrm{mg}, 1.00 \mathrm{mmol})$. Isolation by column chromatography ( $n$-hexane/EtOAc: $5 / 1)$ yielded 133jc (118 mg, 86\%) as a white solid.

M. p. $=142-143^{\circ} \mathrm{C}$.

${ }^{1} \mathbf{H}$ NMR $\left(300 \mathrm{MHz}, \mathrm{CDCl}_{3}\right): \delta=7.87(\mathrm{~d}, J=15.8 \mathrm{~Hz}, 1 \mathrm{H}), 7.59(\mathrm{dd}, J=7.4,1.8 \mathrm{~Hz}, 1 \mathrm{H}), 7.38-7.23$ $(\mathrm{m}, 3 \mathrm{H}), 6.35(\mathrm{~d}, J=15.8 \mathrm{~Hz}, 1 \mathrm{H}), 5.32(\mathrm{~s} \mathrm{br}, 1 \mathrm{H}), 3.77(\mathrm{~s}, 3 \mathrm{H}), 3.67(\mathrm{~s}, 2 \mathrm{H}), 3.21-3.12(\mathrm{~m}, 2 \mathrm{H}), 1.42-$ $1.28(\mathrm{~m}, 2 \mathrm{H}), 1.27-1.13(\mathrm{~m}, 2 \mathrm{H}), 0.83(\mathrm{t}, J=7.2 \mathrm{~Hz}, 3 \mathrm{H})$.

${ }^{13} \mathrm{C}$ NMR $\left(125 \mathrm{MHz}, \mathrm{CDCl}_{3}\right): \delta=169.5\left(\mathrm{C}_{\mathrm{q}}\right), 166.7\left(\mathrm{C}_{\mathrm{q}}\right), 141.2(\mathrm{CH}), 134.3\left(\mathrm{C}_{\mathrm{q}}\right), 133.9\left(\mathrm{C}_{\mathrm{q}}\right), 31.3$ $(\mathrm{CH}), 130.4(\mathrm{CH}), 128.0(\mathrm{CH}), 127.1(\mathrm{CH}), 120.5(\mathrm{CH}), 51.8\left(\mathrm{CH}_{3}\right), 41.3\left(\mathrm{CH}_{2}\right), 39.5\left(\mathrm{CH}_{2}\right), 31.6$ $\left(\mathrm{CH}_{2}\right), 20.0\left(\mathrm{CH}_{2}\right), 13.7\left(\mathrm{CH}_{3}\right)$.

IR (ATR): 2955, 1713, 1637, 1546, 1315, 1167, $762 \mathrm{~cm}^{-1}$.

MS (ESI) $m / z$ (relative intensity): $298(100)[\mathrm{M}+\mathrm{Na}]^{+}, 276(45)[\mathrm{M}+\mathrm{H}]^{+}, 244(70)$.

HR-MS (ESI) $m / z$ calcd for $\mathrm{C}_{16} \mathrm{H}_{21} \mathrm{NO}_{3}[\mathrm{M}+\mathrm{H}]^{+}:$276.1594, found: 276.1596.<smiles>CCOC(=O)/C=C/c1ccccc1CC(=O)N1CCOCC1</smiles>

\section{(E)-n-Butyl 3-[2-(2-morpholino-2-oxoethyl)phenyl]acrylate (133ka):}

The general procedure A was followed using 1-morpholino-2-phenylethanone (132k) (103 mg, 0.50 mmol) and $n$-butyl acrylate (5a) $(128 \mathrm{mg}, 1.00 \mathrm{mmol})$. Isolation by column chromatography ( $n$-hexane/EtOAc: 5/1) yielded 133ka ( $89 \mathrm{mg}, 54 \%)$ as colorless oil. 
${ }^{1}$ H NMR $\left(300 \mathrm{MHz}, \mathrm{CDCl}_{3}\right): \delta=7.82(\mathrm{~d}, J=15.8 \mathrm{~Hz}, 1 \mathrm{H}), 7.57(\mathrm{dd}, J=7.4,1.6 \mathrm{~Hz}, 1 \mathrm{H}), 7.35-7.25$ (m, 2H), $7.20(\mathrm{dd}, J=7.4,1.5 \mathrm{~Hz}, 1 \mathrm{H}), 6.34(\mathrm{~d}, J=15.8 \mathrm{~Hz}, 1 \mathrm{H}), 4.18(\mathrm{t}, J=6.7 \mathrm{~Hz}, 2 \mathrm{H}), 3.79(\mathrm{~s}, 2 \mathrm{H})$, 3.66-3.56 (m, 6H), 3.47-3.41 (m, 2H), 1.71-1.61 (m, 2H), 1.49-1.32 (m, 2H), $0.94(\mathrm{t}, J=7.4 \mathrm{~Hz}, 3 \mathrm{H})$. ${ }^{13}$ C NMR $\left(75 \mathrm{MHz}, \mathrm{CDCl}_{3}\right): \delta=169.0\left(\mathrm{C}_{\mathrm{q}}\right), 166.8\left(\mathrm{C}_{\mathrm{q}}\right), 141.3(\mathrm{CH}), 134.5\left(\mathrm{C}_{\mathrm{q}}\right), 133.6\left(\mathrm{C}_{\mathrm{q}}\right), 130.2$ $(\mathrm{CH}), 130.1(\mathrm{CH}), 127.6(\mathrm{CH}), 127.0(\mathrm{CH}), 120.5(\mathrm{CH}), 66.8\left(\mathrm{CH}_{2}\right), 66.5\left(\mathrm{CH}_{2}\right), 64.5\left(\mathrm{CH}_{2}\right), 46.4$ $\left(\mathrm{CH}_{2}\right), 42.3\left(\mathrm{CH}_{2}\right), 37.5\left(\mathrm{CH}_{2}\right), 30.8\left(\mathrm{CH}_{2}\right), 19.2\left(\mathrm{CH}_{2}\right), 13.7\left(\mathrm{CH}_{3}\right)$.

IR (ATR): 2958, 1708, 1633, 1433, 1169, 1113, $763 \mathrm{~cm}^{-1}$. MS (ESI) $m / z$ (relative intensity): 354 (100) $[\mathrm{M}+\mathrm{Na}]^{+}, 332(70)[\mathrm{M}+\mathrm{H}]^{+}, 258(40)$.

HR-MS (ESI) $m / z$ calcd for $\mathrm{C}_{19} \mathrm{H}_{26} \mathrm{NO}_{4}[\mathrm{M}+\mathrm{H}]^{+}: 332.1856$, found: 332.1854 .<smiles>CCOC(=O)/C=C/c1ccccc1CC(=O)N1CCCC1</smiles>

\section{(E)-n-Butyl 3-\{2-[2-oxo-2-(pyrrolidin-1-yl)ethyl]phenyl\}acrylate (133la):}

The general procedure A was followed using 2-phenyl-1-(pyrrolidin-1-yl)ethanone (132l) (94.5 mg, $0.50 \mathrm{mmol})$ and $n$-butyl acrylate $(\mathbf{5 a})(128 \mathrm{mg}, 1.00 \mathrm{mmol})$. Isolation by column chromatography ( $n$-hexane/EtOAc: $5 / 1)$ yielded 133la (139 $\mathrm{mg}, 88 \%)$ as a white oil.

${ }^{1}$ H NMR $\left(300 \mathrm{MHz}, \mathrm{CDCl}_{3}\right): \delta=7.85(\mathrm{~d}, J=15.5,1 \mathrm{H}), 7.55(\mathrm{dd}, J=7.8,1.4 \mathrm{~Hz}, 1 \mathrm{H}), 7.33-7.19(\mathrm{~m}$, $3 \mathrm{H}), 6.33(\mathrm{~d}, J=15.5 \mathrm{~Hz}, 1 \mathrm{H}), 4.16(\mathrm{dd}, J=8.4,4.9 \mathrm{~Hz}, 2 \mathrm{H}), 3.73(\mathrm{~s}, 2 \mathrm{H}), 3.43-3.49$ (m, 4H), 1.98 $1.89(\mathrm{~m}, 2 \mathrm{H}), 1.87-1.80(\mathrm{~m}, 2 \mathrm{H}), 1.70-1.58(\mathrm{~m}, 2 \mathrm{H}), 1.47-1.34(\mathrm{~m}, 2 \mathrm{H}), 0.93(\mathrm{t}, J=8.6 \mathrm{~Hz}, 3 \mathrm{H})$.

${ }^{13}$ C NMR $\left(100 \mathrm{MHz}, \mathrm{CDCl}_{3}\right): \delta=167.6\left(\mathrm{C}_{\mathrm{q}}\right), 165.9\left(\mathrm{C}_{\mathrm{q}}\right), 140.8(\mathrm{CH}), 133.8\left(\mathrm{C}_{\mathrm{q}}\right), 132.8\left(\mathrm{C}_{\mathrm{q}}\right), 129.4$ $(\mathrm{CH}), 129.0(\mathrm{CH}), 126.3(\mathrm{CH}), 125.7(\mathrm{CH}), 119.1(\mathrm{CH}), 63.3\left(\mathrm{CH}_{2}\right), 45.8\left(\mathrm{CH}_{2}\right), 44.9\left(\mathrm{CH}_{2}\right), 38.1$ $\left(\mathrm{CH}_{2}\right), 29.7\left(\mathrm{CH}_{2}\right), 25.1\left(\mathrm{CH}_{2}\right), 23.3\left(\mathrm{CH}_{2}\right), 18.1\left(\mathrm{CH}_{2}\right), 12.7\left(\mathrm{CH}_{3}\right)$.

IR (ATR): 2958, 1707, 1632, 1431, 1311, 1216, $730 \mathrm{~cm}^{-1}$.

MS (ESI) $m / z$ (relative intensity): $338(65)[\mathrm{M}+\mathrm{Na}]^{+}, 316(100)[\mathrm{M}+\mathrm{H}]^{+}$.

HR-MS (ESI) $m / z$ calcd for $\mathrm{C}_{19} \mathrm{H}_{26} \mathrm{NO}_{3}[\mathrm{M}+\mathrm{H}]^{+}: 316.1907$, found: 316.1912 . 
<smiles>CCCN(C(=O)Cc1ccccc1/C=C/C(C)=O)C(C)C</smiles>

\section{(E)-Methyl 3-\{2-[2-(diisopropylamino)-2-oxoethyl]phenyl\}xacrylate (133mc):}

The general procedure A was followed using $N, N$-diisopropyl-2-phenylacetamide (132m) (110 mg, $0.50 \mathrm{mmol})$ and methyl acrylate $(\mathbf{5 c})(86 \mathrm{mg}, 1.00 \mathrm{mmol})$. Isolation by column chromatography ( $n$-hexane/EtOAc: $5 / 1)$ yielded 133ma (91 mg, 60\%) as a white solid.

M. p. $=136-137^{\circ} \mathrm{C}$.

${ }^{1}$ H NMR $\left(300 \mathrm{MHz} \mathrm{CDCl}_{3}\right): \delta=7.81(\mathrm{~d}, J=15.8 \mathrm{~Hz}, 1 \mathrm{H}), 7.55(\mathrm{dd}, J=7.5,1.5 \mathrm{~Hz}, 1 \mathrm{H}), 7.34-7.18$ (m, 3H), 6.32 (d, $J=15.8 \mathrm{~Hz}, 1 \mathrm{H}), 3.93(\mathrm{dt}, J=13.3,6.7 \mathrm{~Hz}, 1 \mathrm{H}), 3.76(\mathrm{~s}, 3 \mathrm{H}), 3.75(\mathrm{~s}, 2 \mathrm{H}), 3.43$ (dt, $J=13.0,6.3 \mathrm{~Hz}, 1 \mathrm{H}), 1.38(\mathrm{~d}, J=6.8 \mathrm{~Hz}, 6 \mathrm{H}), 1.15(\mathrm{~d}, J=6.7 \mathrm{~Hz}, 6 \mathrm{H})$.

${ }^{13}$ C NMR $\left(125 \mathrm{MHz}, \mathrm{CDCl}_{3}\right): \delta=168.8\left(\mathrm{C}_{\mathrm{q}}\right), 167.0\left(\mathrm{C}_{\mathrm{q}}\right), 141.9(\mathrm{CH}), 135.5\left(\mathrm{C}_{\mathrm{q}}\right), 133.4\left(\mathrm{C}_{\mathrm{q}}\right), 130.2$ $(\mathrm{CH}), 130.0(\mathrm{CH}), 127.1(\mathrm{CH}), 126.7(\mathrm{CH}), 119.6(\mathrm{CH}), 51.6\left(\mathrm{CH}_{3}\right), 49.2(\mathrm{CH}), 46.0(\mathrm{CH}), 40.1\left(\mathrm{CH}_{2}\right)$, $20.8\left(\mathrm{CH}_{3}\right), 20.5\left(\mathrm{CH}_{3}\right)$.

IR (ATR): 2964, 1712, 1631, 1435, 1336, 1169, $729 \mathrm{~cm}^{-1}$.

MS (ESI) $m / z$ (relative intensity): $326(33)[\mathrm{M}+\mathrm{Na}]^{+}, 304(100)[\mathrm{M}+\mathrm{H}]^{+}, 272(45)$.

HR-MS (ESI) $m / z$ calcd for $\mathrm{C}_{18} \mathrm{H}_{26} \mathrm{NO}_{3}[\mathrm{M}+\mathrm{H}]^{+}: 304.1907$, found: 304.1913 .<smiles>[M]C(NC(=O)Cc1ccccc1/C=C/C(=O)OCC)c1ccccc1</smiles>

\section{(E)-n-Butyl 3-\{2-\{2-oxo-2-[((R)-1-phenylethyl)amino]ethyl\}phenyl\}acrylate (133na):}

The general procedure A was followed using 2-phenyl- $N$ - $\{(R)$-1-phenylethyl $\}$ acetamide (132n) (120 $\mathrm{mg}, 0.50 \mathrm{mmol})$ and $n$-butyl acrylate (5a) $(128 \mathrm{mg}, 1.00 \mathrm{mmol})$. Isolation by column chromatography ( $n$-hexane/EtOAc: $5 / 1)$ yielded 133na (141 mg, 77\%) as a white solid.

M. p. $=77-78^{\circ} \mathrm{C}$. 
${ }^{1}$ H NMR $\left(400 \mathrm{MHz}, \mathrm{CDCl}_{3}\right): \delta=7.88(\mathrm{~d}, J=15.8 \mathrm{~Hz}, 1 \mathrm{H}), 7.58(\mathrm{dd}, J=7.5,1.7 \mathrm{~Hz}, 1 \mathrm{H}), 7.36-7.29$ $(\mathrm{m}, 2 \mathrm{H}), 7.26-7.23(\mathrm{~m}, 3 \mathrm{H}), 7.22-7.19(\mathrm{~m}, 1 \mathrm{H}), 7.18-7.15(\mathrm{~m}, 2 \mathrm{H}), 6.34(\mathrm{~d}, J=15.8 \mathrm{~Hz}, 1 \mathrm{H})$, 5.06-5.11 (m, 1H), $5.62(\mathrm{~s}$ br $1 \mathrm{H}), 4.21-4.15(\mathrm{~m}, 2 \mathrm{H}), 3.68(\mathrm{~s}, 2 \mathrm{H}), 1.66(\mathrm{dq}, J=12.3,6.9 \mathrm{~Hz}, 2 \mathrm{H})$, $1.47-1.38(\mathrm{~m}, 2 \mathrm{H}), 1.37(\mathrm{~d}, J=7.0 \mathrm{~Hz}, 3 \mathrm{H}), 0.94(\mathrm{t}, J=7.4 \mathrm{~Hz}, 3 \mathrm{H})$.

${ }^{13} \mathrm{C}$ NMR $\left(100 \mathrm{MHz}, \mathrm{CDCl}_{3}\right): \delta=168.9\left(\mathrm{C}_{\mathrm{q}}\right), 166.5\left(\mathrm{C}_{\mathrm{q}}\right), 142.8\left(\mathrm{C}_{\mathrm{q}}\right), 141.0(\mathrm{CH}), 131.3\left(\mathrm{C}_{\mathrm{q}}\right), 130.4$ $\left(\mathrm{C}_{\mathrm{q}}\right), 129.3(\mathrm{CH}), 129.0(\mathrm{CH}), 128.5(\mathrm{CH}), 128.1(\mathrm{CH}), 127.2(\mathrm{CH}), 127.1(\mathrm{CH}), 126.0(\mathrm{CH}), 121.0$ $(\mathrm{CH}), 64.5\left(\mathrm{CH}_{2}\right), 48.8(\mathrm{CH}), 41.3\left(\mathrm{CH}_{2}\right), 30.7\left(\mathrm{CH}_{2}\right), 21.4\left(\mathrm{CH}_{3}\right), 19.1\left(\mathrm{CH}_{2}\right), 13.6\left(\mathrm{CH}_{3}\right)$.

IR (ATR): 2960, 1712, 1641, 1541, 1312, 1171, $699 \mathrm{~cm}^{-1}$. MS (ESI) $\mathrm{m} / z$ (relative intensity): 388 (100) $[\mathrm{M}+\mathrm{Na}]^{+}, 366(57)[\mathrm{M}+\mathrm{H}]^{+}$.

HR-MS (ESI) $m / z$ calcd for $\mathrm{C}_{23} \mathrm{H}_{28} \mathrm{NO}_{3}[\mathrm{M}+\mathrm{H}]^{+}$: 366.2064, found: 366.2064.

HPLC ( $n$-hexane/iPrOH: 70/30): $t=5.20 \mathrm{~min}$.
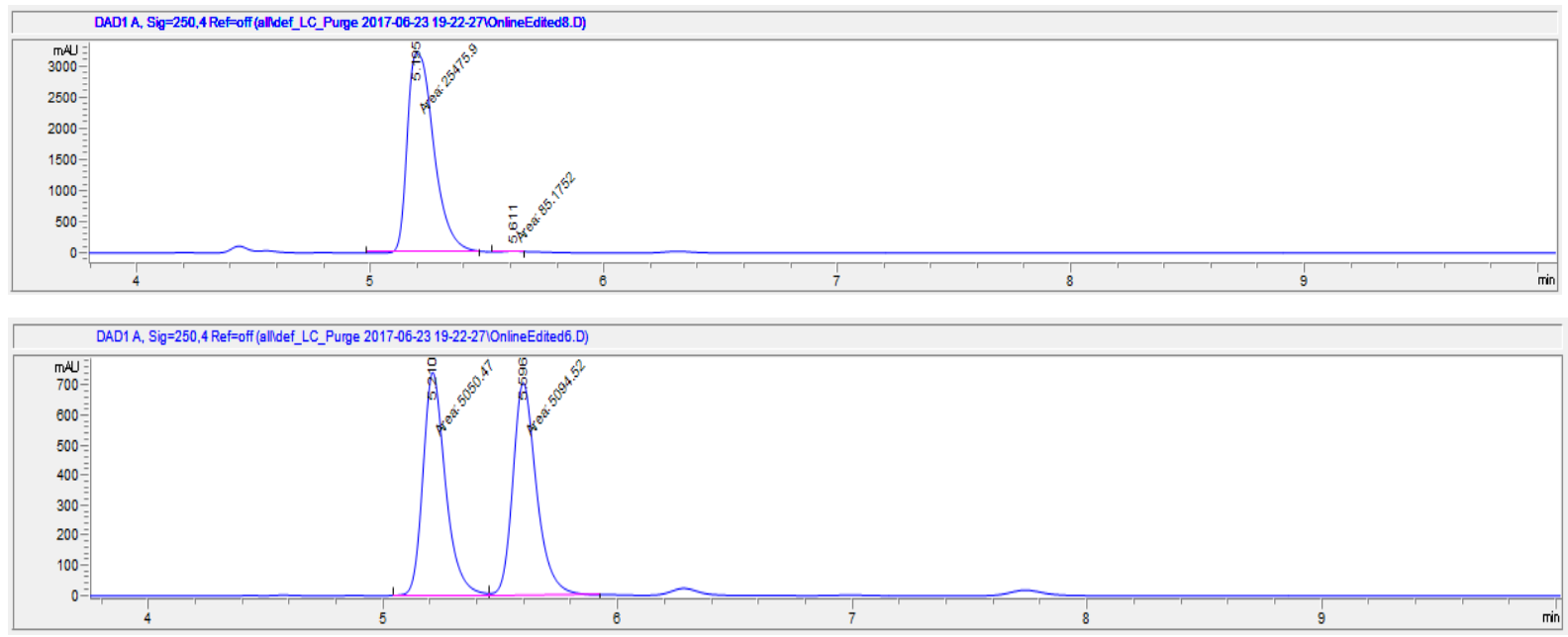<smiles>CCOC(=O)/C=C/c1ccccc1CC(=O)NCCCOC(C)(C)C</smiles>

\section{(E)-n-Butyl 3-\{2-\{2-[(3-acetoxypropyl)amino]-2-oxoethyl\}phenyl\}acrylate (1330a):}

The general procedure A was followed using 3-(2-phenylacetamido)propyl acetate (132o) (118 mg, $0.50 \mathrm{mmol})$ and $n$-butyl acrylate $(\mathbf{5 a})(128 \mathrm{mg}, 1.00 \mathrm{mmol})$. Isolation by column chromatography ( $n$-hexane/EtOAc: $5 / 1)$ yielded $1330 a(110 \mathrm{mg}, 61 \%)$ as a colorless oil. 
${ }^{1}$ H NMR $\left(300 \mathrm{MHz}, \mathrm{CDCl}_{3}\right): \delta=7.85(\mathrm{~d}, J=15.8 \mathrm{~Hz}, 1 \mathrm{H}), 7.57(\mathrm{dd}, J=7.3,1.7 \mathrm{~Hz}, 1 \mathrm{H}), 7.35-7.22$ $(\mathrm{m}, 3 \mathrm{H}), 6.34(\mathrm{~d}, J=15.8 \mathrm{~Hz}, 1 \mathrm{H}), 5.81\left(\mathrm{~s}_{\mathrm{br}}, 1 \mathrm{H}\right), 4.15(\mathrm{t}, J=6.7 \mathrm{~Hz}, 2 \mathrm{H}), 3.98(\mathrm{t}, J=6.0,2 \mathrm{H}), 3.65(\mathrm{~s}$, 2H), $3.22(\mathrm{dd}, J=12.8,6.7 \mathrm{~Hz}, 2 \mathrm{H}), 1.94$ (s, 3H), 1.77-1.68 (m, 2H), 1.67-1.59 (m, 2H), 1.34-1.32 (m, $2 \mathrm{H}), 0.92(\mathrm{t}, J=7.3 \mathrm{~Hz}, 3 \mathrm{H})$.

${ }^{13}$ C NMR (125 MHz, $\left.\mathrm{CDCl}_{3}\right): \delta=170.9\left(\mathrm{C}_{\mathrm{q}}\right), 169.8\left(\mathrm{C}_{\mathrm{q}}\right), 166.4\left(\mathrm{C}_{\mathrm{q}}\right), 140.9(\mathrm{CH}), 134.1\left(\mathrm{C}_{\mathrm{q}}\right), 133.9$ $\left(\mathrm{C}_{\mathrm{q}}\right), 131.1(\mathrm{CH}), 130.2(\mathrm{CH}), 127.9(\mathrm{CH}), 127.0(\mathrm{CH}), 120.7(\mathrm{CH}), 64.4\left(\mathrm{CH}_{2}\right), 61.7\left(\mathrm{CH}_{2}\right), 41.1$ $\left(\mathrm{CH}_{2}\right), 36.5\left(\mathrm{CH}_{2}\right), 30.7\left(\mathrm{CH}_{2}\right), 28.6\left(\mathrm{CH}_{2}\right), 20.8\left(\mathrm{CH}_{3}\right), 19.2\left(\mathrm{CH}_{2}\right), 13.7\left(\mathrm{CH}_{3}\right)$.

IR (ATR): 2961, 1710, 1649, 1239, 1174, 907, $726 \mathrm{~cm}^{-1}$.

MS (ESI) $\mathrm{m} / z$ (relative intensity): $384(100)[\mathrm{M}+\mathrm{Na}]^{+}, 362(70)[\mathrm{M}+\mathrm{H}]^{+}$.

HR-MS (ESI) $m / z$ calcd for $\mathrm{C}_{20} \mathrm{H}_{28} \mathrm{NO}_{5}[\mathrm{M}+\mathrm{H}]^{+}: 362.1962$, found: 362.1961 .<smiles>COC(=O)C=Cc1cc(F)ccc1CC(=O)NC(C)(C)C</smiles>

\section{(E)-Methyl 3-\{2-[2-(tert-butylamino)-2-oxoethyl]-5-fluorophenyl\}acrylate (133pc):}

The general procedure A was followed using $N$-(tert-butyl)-2-(4-fluorophenyl)acetamide (132p) (105 $\mathrm{mg}, 0.50 \mathrm{mmol})$ and methyl acrylate $(\mathbf{5 c})(86 \mathrm{mg}, 1.00 \mathrm{mmol})$. Isolation by column chromatography ( $n$-hexane/EtOAc: $5 / 1)$ yielded 133pc (119 mg, 81\%) as a white solid.

M. p. $=147-148^{\circ} \mathrm{C}$.

${ }^{1}$ H NMR (400 MHz, $\left.\mathrm{CDCl}_{3}\right): \delta=7.80(\mathrm{dd}, J=15.8,1.5 \mathrm{~Hz}, 1 \mathrm{H}), 7.26-7.19(\mathrm{~m}, 2 \mathrm{H}), 7.02(\mathrm{td}, J=8.2$, $2.7 \mathrm{~Hz}, 1 \mathrm{H}), 6.32(\mathrm{~d}, J=15.8 \mathrm{~Hz}, 1 \mathrm{H}), 5.28(\mathrm{~s} b \mathrm{H}, 1 \mathrm{H}), 3.77$ (s, 3H), $3.53(\mathrm{~s}, 2 \mathrm{H}), 1.26(\mathrm{~s}, 9 \mathrm{H})$.

${ }^{13} \mathrm{C} \mathrm{NMR}\left(100 \mathrm{MHz}, \mathrm{CDCl}_{3}\right): \delta=168.9\left(\mathrm{C}_{\mathrm{q}}\right), 166.6\left(\mathrm{C}_{\mathrm{q}}\right), 162.0\left(\mathrm{C}_{\mathrm{q}},{ }^{1} J_{\mathrm{C}-\mathrm{F}}=246.7 \mathrm{~Hz}\right), 140.6\left(\mathrm{CH},{ }^{4} J_{\mathrm{C}-}\right.$ $\mathrm{F}=2.3 \mathrm{~Hz}), 135.7\left(\mathrm{C}_{\mathrm{q}},{ }^{3} J_{\mathrm{C}-\mathrm{F}}=7.7 \mathrm{~Hz}\right), 132.9\left(\mathrm{CH},{ }^{3} J_{\mathrm{C}-\mathrm{F}}=8.2 \mathrm{~Hz}\right), 130.7\left(\mathrm{C}_{\mathrm{q}},{ }^{4} J_{\mathrm{C}-\mathrm{F}}=3.2 \mathrm{~Hz}\right), 121.2$ $(\mathrm{CH}), 117.2\left(\mathrm{CH},{ }^{2} J_{\mathrm{C}-\mathrm{F}}=21.4 \mathrm{~Hz}\right), 113.4\left(\mathrm{CH},{ }^{2} J_{\mathrm{C}-\mathrm{F}}=22.4 \mathrm{~Hz}\right), 51.8\left(\mathrm{CH}_{3}\right), 51.5\left(\mathrm{C}_{\mathrm{q}}\right), 41.4\left(\mathrm{CH}_{2}\right)$, $28.6\left(\mathrm{CH}_{3}\right)$.

${ }^{19}$ F NMR $\left(376 \mathrm{~Hz}, \mathrm{CDCl}_{3}\right): \delta=-114.3$.

IR (ATR): 2967, 1718, 1645, 1491, 1266, 1171, $977 \mathrm{~cm}^{-1}$.

MS (ESI) $m / z$ (relative intensity): $316(90)[\mathrm{M}+\mathrm{Na}]^{+}, 294(100)[\mathrm{M}+\mathrm{H}]^{+}$.

HR-MS (ESI) $m / z$ calcd for $\mathrm{C}_{16} \mathrm{H}_{21} \mathrm{FNO}_{3}[\mathrm{M}+\mathrm{H}]^{+}:$: 294.1500, found: 294.1502. 
<smiles>COC(=O)C=Cc1cc(OC)ccc1CC(=O)NC(C)(C)C</smiles>

\section{(E)-Methyl 3-\{2-[2-(tert-butylamino)-2-oxoethyl]-5-methoxyphenyl\}acrylate (133qc):}

The general procedure A was followed using $N$-(tert-butyl)-2-(4-methoxyphenyl)acetamide (132q) $(111 \mathrm{mg}, 0.50 \mathrm{mmol})$ and methyl acrylate $(\mathbf{5 c})(86 \mathrm{mg}, 1.00 \mathrm{mmol})$. Isolation by column chromatography ( $n$-hexane/EtOAc: $5 / 1)$ yielded 133qc (111 mg, 73\%) as a white solid.

M. p. $=142-143{ }^{\circ} \mathrm{C}$

${ }^{1}$ H NMR (500 MHz, $\left.\mathrm{CDCl}_{3}\right): \delta=7.84(\mathrm{~d}, J=15.7 \mathrm{~Hz}, 1 \mathrm{H}), 7.17(\mathrm{~d}, J=8.3 \mathrm{~Hz}, 1 \mathrm{H}), 7.10(\mathrm{~d}, J=2.1 \mathrm{~Hz}$, $1 \mathrm{H}), 6.95-6.89(\mathrm{~m}, 1 \mathrm{H}), 6.35(\mathrm{~d}, J=15.7 \mathrm{~Hz}, 1 \mathrm{H}), 5.16\left(\mathrm{~s}_{\mathrm{br}}, 1 \mathrm{H}\right), 3.83(\mathrm{~s}, 3 \mathrm{H}), 3.80(\mathrm{~s}, 3 \mathrm{H}), 3.55(\mathrm{~s}, 2 \mathrm{H})$, $1.26(\mathrm{~s}, 9 \mathrm{H})$.

${ }^{13}$ C NMR (125 MHz, $\left.\mathrm{CDCl}_{3}\right): \delta=207.0\left(\mathrm{C}_{\mathrm{q}}\right), 166.9\left(\mathrm{C}_{\mathrm{q}}\right), 159.0\left(\mathrm{C}_{\mathrm{q}}\right), 141.6(\mathrm{CH}), 134.9\left(\mathrm{C}_{\mathrm{q}}\right), 132.5$ $(\mathrm{CH}), 127.1\left(\mathrm{C}_{\mathrm{q}}\right), 120.3(\mathrm{CH}), 116.4(\mathrm{CH}), 111.9(\mathrm{CH}), 55.4\left(\mathrm{CH}_{3}\right), 51.8\left(\mathrm{CH}_{3}\right), 51.3\left(\mathrm{C}_{\mathrm{q}}\right), 41.6\left(\mathrm{CH}_{2}\right)$, $28.6\left(\mathrm{CH}_{3}\right)$. IR (ATR): 2965, 1715, 1645, 1496, 1228, 1194, $978 \mathrm{~cm}^{-1}$. MS (ESI) $\mathrm{m} / z$ (relative intensity): $328(33)[\mathrm{M}+\mathrm{Na}]^{+}, 306(40)[\mathrm{M}+\mathrm{H}]^{+}, 274(20)$

HR-MS (ESI) $m / z$ calcd for $\mathrm{C}_{17} \mathrm{H}_{24} \mathrm{NO}_{4}[\mathrm{M}+\mathrm{H}]^{+}: 306.1700$, found: 306.1703 .<smiles>COC(C)(C)C(C)(C)C</smiles>

\section{(E)-Methyl 3-\{5-acetoxy-2-[2-(tert-butylamino)-2-oxoethyl]phenyl\}acrylate (133rc):}

The general procedure A was followed using 4-[2-(tert-butylamino)-2-oxoethyl]phenyl acetate (132r) (125 $\mathrm{mg}, 0.50 \mathrm{mmol})$ and methyl acrylate $(\mathbf{5 c})(86 \mathrm{mg}, 1.00 \mathrm{mmol})$. Isolation by column chromatography ( $n$-hexane/EtOAc: $5 / 1)$ yielded 133rc (117 mg, 70\%) as a white solid. 
M. p. $=128-129^{\circ} \mathrm{C}$.

${ }^{1}$ H NMR $\left(300 \mathrm{MHz}, \mathrm{CDCl}_{3}\right): \delta=7.77(\mathrm{~d}, J=15.8 \mathrm{~Hz}, 1 \mathrm{H}), 7.25(\mathrm{~d}, J=2.1 \mathrm{~Hz}, 1 \mathrm{H}), 7.22(\mathrm{~d}, J=8.3 \mathrm{~Hz}$, 1H), 7.06-7.01 (m, 1H), $6.28(\mathrm{~d}, J=15.8 \mathrm{~Hz}, 1 \mathrm{H}), 5.16\left(\mathrm{~s}_{\mathrm{br}}, 1 \mathrm{H}\right), 3.73(\mathrm{~s}, 3 \mathrm{H}), 3.51(\mathrm{~s}, 2 \mathrm{H}), 2.24(\mathrm{~s}, 3 \mathrm{H})$, $1.22(\mathrm{~s}, 9 \mathrm{H})$.

${ }^{13} \mathrm{C}$ NMR $\left(125 \mathrm{MHz}, \mathrm{CDCl}_{3}\right): \delta=169.0\left(\mathrm{C}_{\mathrm{q}}\right), 168.6\left(\mathrm{C}_{\mathrm{q}}\right), 166.6\left(\mathrm{C}_{\mathrm{q}}\right), 150.0\left(\mathrm{C}_{\mathrm{q}}\right), 140.7(\mathrm{CH}), 135.1$ $\left(\mathrm{C}_{\mathrm{q}}\right), 132.3\left(\mathrm{C}_{\mathrm{q}}\right), 132.2(\mathrm{CH}), 123.4(\mathrm{CH}), 121.0(\mathrm{CH}), 119.8(\mathrm{CH}), 51.8\left(\mathrm{CH}_{3}\right), 51.6\left(\mathrm{C}_{\mathrm{q}}\right), 41.7\left(\mathrm{CH}_{2}\right)$, $28.7\left(\mathrm{CH}_{3}\right), 21.2\left(\mathrm{CH}_{3}\right)$.

IR (ATR): 2967, 1762, 1716, 1648, 1203, 1171, $731 \mathrm{~cm}^{-1}$.

MS (ESI) $m / z$ (relative intensity): $356(50)[\mathrm{M}+\mathrm{Na}]^{+}, 334(100)[\mathrm{M}+\mathrm{H}]^{+}, 302(45)$.

HR-MS (ESI) $m / z$ calcd for $\mathrm{C}_{18} \mathrm{H}_{24} \mathrm{NO}_{5}[\mathrm{M}+\mathrm{H}]^{+}: 334.1649$, found: 334.1646 .<smiles>COC(=O)NC(=O)Cc1ccc(NC(C)(C)C)cc1C=CC(C)(C)C</smiles>

(E)-Methyl 3-\{2-[2-(tert-butylamino)-2-oxoethyl]-5-(4-methylphenylsulfonamido)-phenyl\}acrylate (133sc):

The general procedure A was followed using $N$-(tert-butyl)-2-[4-(4-methylphenylsulfonamido)phenyl]acetamide (132s) (180 $\mathrm{mg}, 0.50 \mathrm{mmol}$ ) and methyl acrylate (5c) (86 mg, $1.00 \mathrm{mmol})$. Isolation by column chromatography ( $n$-hexane/EtOAc: $5 / 1)$ yielded 133sc (147 mg, 66\%) as a white solid.

M. p. $=152-153^{\circ} \mathrm{C}$.

${ }^{1}$ H NMR $\left(300 \mathrm{MHz}, \mathrm{CDCl}_{3}\right): \delta=7.74(\mathrm{~d}, J=15.8 \mathrm{~Hz}, 1 \mathrm{H}), 7.65(\mathrm{~d}, J=8.1 \mathrm{~Hz}, 2 \mathrm{H}), 7.43\left(\mathrm{~s}_{\mathrm{br}}, 1 \mathrm{H}\right)$, $7.20(\mathrm{~d}, J=8.1 \mathrm{~Hz}, 2 \mathrm{H}), 7.18(\mathrm{~d}, J=2.2 \mathrm{~Hz}, 1 \mathrm{H}), 7.07(\mathrm{~d}, J=8.2 \mathrm{~Hz}, 1 \mathrm{H}), 6.97(\mathrm{dd}, J=8.2,2.2 \mathrm{~Hz}, 1 \mathrm{H})$, $6.17(\mathrm{~d}, J=15.8 \mathrm{~Hz}, 1 \mathrm{H}), 5.30\left(\mathrm{~s}_{\mathrm{br}}, 1 \mathrm{H}\right), 3.79(\mathrm{~s}, 3 \mathrm{H}), 3.51$ (s, 2H), $2.36(\mathrm{~s}, 3 \mathrm{H}), 1.30(\mathrm{~s}, 9 \mathrm{H})$.

${ }^{13} \mathrm{C}$ NMR $\left(125 \mathrm{MHz}, \mathrm{CDCl}_{3}\right): \delta=168.4\left(\mathrm{C}_{\mathrm{q}}\right), 165.9\left(\mathrm{C}_{\mathrm{q}}\right), 142.9\left(\mathrm{C}_{\mathrm{q}}\right), 140.0(\mathrm{CH}), 135.5\left(\mathrm{C}_{\mathrm{q}}\right), 135.2$ $\left(\mathrm{C}_{\mathrm{q}}\right), 133.6\left(\mathrm{C}_{\mathrm{q}}\right), 131.3(\mathrm{CH}), 130.4\left(\mathrm{C}_{\mathrm{q}}\right), 128.6(\mathrm{CH}), 126.2(\mathrm{CH}), 122.5(\mathrm{CH}), 119.8(\mathrm{CH}), 118.7(\mathrm{CH})$, $50.8\left(\mathrm{CH}_{3}\right), 50.7\left(\mathrm{C}_{\mathrm{q}}\right), 40.5\left(\mathrm{CH}_{2}\right), 27.5\left(\mathrm{CH}_{3}\right), 20.5\left(\mathrm{CH}_{3}\right)$.

IR (ATR): 2966, 1718, 1649, 1321, 1159, 1092, $543 \mathrm{~cm}^{-1}$.

MS (ESI) $m / z$ (relative intensity): $467(100)[\mathrm{M}+\mathrm{Na}]^{+}, 445(70)[\mathrm{M}+\mathrm{H}]^{+}, 413(20)$.

HR-MS (ESI) $m / z$ calcd for $\mathrm{C}_{23} \mathrm{H}_{29} \mathrm{~N}_{2} \mathrm{O}_{5} \mathrm{~S}[\mathrm{M}+\mathrm{H}]^{+}:$445.1792, found: 445.1791 . 
<smiles>COC(=O)C=Cc1ccc(Br)cc1CC(=O)NC(C)(C)C</smiles>

\section{(E)-Methyl 3-\{4-bromo-2-[2-(tert-butylamino)-2-oxoethyl]phenyl\}acrylate (133tc):}

The general procedure A was followed using 2-(3-bromophenyl)- $N$-(tert-butyl)acetamide (132t) (135 $\mathrm{mg}, 0.50 \mathrm{mmol})$ and methyl acrylate $(\mathbf{5 c})(86 \mathrm{mg}, 1.00 \mathrm{mmol})$. Isolation by column chromatography ( $n$-hexane/EtOAc: $5 / 1)$ yielded 133tc (150 mg, 85\%) as a white solid.

Gram-scale reaction: The general procedure $\mathbf{A}$ was followed using 2-(3-bromophenyl)$N$-(tert-butyl)acetamide (132t) (1.08 g, $4.00 \mathrm{mmol})$ and methyl acrylate (5c) $(0.69 \mathrm{~g}, 8.00 \mathrm{mmol})$ in THF (16 mL). Recrystallization from PhMe yielded 133tc (1.17 g, 83\%) as a white solid.

M. p. $=143-144{ }^{\circ} \mathrm{C}$.

${ }^{1}$ H NMR $\left(400 \mathrm{MHz}, \mathrm{CDCl}_{3}\right): \delta=7.81(\mathrm{~d}, J=15.8 \mathrm{~Hz}, 1 \mathrm{H}), 7.47-7.45(\mathrm{~m}, 2 \mathrm{H}), 7.45-7.44(\mathrm{~m}, 1 \mathrm{H})$, $6.36(\mathrm{~d}, J=15.8 \mathrm{~Hz}, 1 \mathrm{H}), 5.30(\mathrm{~s} \mathrm{br}, 1 \mathrm{H}), 3.80(\mathrm{~s}, 3 \mathrm{H}), 3.56(\mathrm{~s}, 2 \mathrm{H}), 1.30(\mathrm{~s}, 9 \mathrm{H})$.

${ }^{13}$ C NMR (100 MHz, $\left.\mathrm{CDCl}_{3}\right): \delta=168.3\left(\mathrm{C}_{\mathrm{q}}\right), 166.8\left(\mathrm{C}_{\mathrm{q}}\right), 140.6(\mathrm{CH}), 136.7\left(\mathrm{C}_{\mathrm{q}}\right), 134.2(\mathrm{CH}), 132.9$ $\left(\mathrm{C}_{\mathrm{q}}\right), 131.0(\mathrm{CH}), 128.4(\mathrm{CH}), 124.4\left(\mathrm{C}_{\mathrm{q}}\right), 120.6(\mathrm{CH}), 51.8\left(\mathrm{CH}_{3}\right), 51.7\left(\mathrm{C}_{\mathrm{q}}\right), 41.9\left(\mathrm{CH}_{2}\right), 28.6\left(\mathrm{CH}_{3}\right)$. IR (ATR): 2970, 1713, 1644, 1586, 1315, 1172, $821 \mathrm{~cm}^{-1}$.

MS (ESI) $m / z$ (relative intensity): $376(95)\left([\mathrm{M}+\mathrm{Na}]^{+},{ }^{79} \mathrm{Br}\right), 356(100)\left([\mathrm{M}+\mathrm{H}]^{+},{ }^{81} \mathrm{Br}\right)$.

HR-MS (ESI) $m / z$ calcd for $\mathrm{C}_{16} \mathrm{H}_{21}{ }^{79} \mathrm{BrNO}_{3}[\mathrm{M}+\mathrm{H}]^{+}: 354.0699$, found: 354.0699 .<smiles>COC(=O)C=Cc1ccc(-c2ccccc2)cc1CC(=O)NC(C)(C)C</smiles>

\section{(E)-Methyl 3-\{3-[2-(tert-butylamino)-2-oxoethyl]-[1,1'-biphenyl]-4-yl\}acrylate (133uc):}

The general procedure A was followed using 2-([1,1'-biphenyl]-3-yl)- $N$-(tert-butyl)acetamide (132u) (134 $\mathrm{mg}, 0.50 \mathrm{mmol})$ and methyl acrylate $(\mathbf{5 c})(86 \mathrm{mg}, 1.00 \mathrm{mmol})$. Isolation by column chromatography ( $n$-hexane/EtOAc: $5 / 1)$ yielded 133uc (158 mg, 90\%) as a white solid.

M. p. $=182-183^{\circ} \mathrm{C}$. 
${ }^{1}$ H NMR (300 MHz, $\left.\mathrm{CDCl}_{3}\right): \delta=7.93(\mathrm{~d}, J=15.8 \mathrm{~Hz}, 1 \mathrm{H}), 7.69(\mathrm{~d}, J=8.1 \mathrm{~Hz}, 1 \mathrm{H}), 7.61-7.57$ (m, 2H), $7.56(\mathrm{dd}, J=8.1,1.5 \mathrm{~Hz}, 1 \mathrm{H}), 7.51(\mathrm{~d}, J=1.7 \mathrm{~Hz}, 1 \mathrm{H}), 7.48-7.43(\mathrm{~m}, 2 \mathrm{H}), 7.40-7.35(\mathrm{~m}, 1 \mathrm{H}), 6.42(\mathrm{~d}$, $J=15.8 \mathrm{~Hz}, 1 \mathrm{H}), 5.25(\mathrm{~s} b \mathrm{H}, 1 \mathrm{H}), 3.81(\mathrm{~s}, 3 \mathrm{H}), 3.69(\mathrm{~s}, 2 \mathrm{H}), 1.30(\mathrm{~s}, 9 \mathrm{H})$.

${ }^{13}$ C NMR (100 MHz, $\left.\mathrm{CDCl}_{3}\right): \delta=169.0\left(\mathrm{C}_{\mathrm{q}}\right), 167.0\left(\mathrm{C}_{\mathrm{q}}\right), 143.2\left(\mathrm{C}_{\mathrm{q}}\right), 141.2(\mathrm{CH}), 139.8\left(\mathrm{C}_{\mathrm{q}}\right), 135.4$ $\left(\mathrm{C}_{\mathrm{q}}\right), 132.7\left(\mathrm{C}_{\mathrm{q}}\right), 129.9(\mathrm{CH}), 128.9(\mathrm{CH}), 128.0(\mathrm{CH}), 127.5(\mathrm{CH}), 127.0(\mathrm{CH}), 126.5(\mathrm{CH}), 119.9$ $(\mathrm{CH}), 51.8\left(\mathrm{C}_{\mathrm{q}}\right), 51.5\left(\mathrm{CH}_{2}\right), 42.6\left(\mathrm{CH}_{3}\right), 28.6\left(\mathrm{CH}_{3}\right)$.

IR (ATR): 2966, 1716, 1645, 1543, 1167, 763, $697 \mathrm{~cm}^{-1}$.

MS (ESI) $m / z$ (relative intensity): $374(50)[\mathrm{M}+\mathrm{Na}]^{+}, 352(100)[\mathrm{M}+\mathrm{H}]^{+}, 320(45)$.

HR-MS (ESI) $m / z$ calcd for $\mathrm{C}_{22} \mathrm{H}_{26} \mathrm{NO}_{3}[\mathrm{M}+\mathrm{H}]^{+}: 352.1907$, found: 352.1905 .<smiles>COC(=O)C=Cc1ccc(C)cc1CC(=O)NC(C)(C)C</smiles>

(E)-Methyl 3-\{2-[2-(tert-butylamino)-2-oxoethyl]-4-methylphenyl\}acrylate (133vc):

The general procedure A was followed using $N$-(tert-butyl)-2-(m-tolyl)acetamide (132v) (103 mg, $0.50 \mathrm{mmol}$ ) and methyl acrylate $(\mathbf{5 c})(86 \mathrm{mg}, 1.00 \mathrm{mmol})$. Isolation by column chromatography ( $n$-hexane/EtOAc: $5 / 1)$ yielded $133 v c(132 \mathrm{mg}, 91 \%)$ as a white solid.

M. p. $=140-141^{\circ} \mathrm{C}$.

${ }^{1}$ H NMR $\left(400 \mathrm{MHz}, \mathrm{CDCl}_{3}\right): \delta=7.86(\mathrm{~d}, J=15.8 \mathrm{~Hz}, 1 \mathrm{H}), 7.51(\mathrm{~d}, J=7.9 \mathrm{~Hz}, 1 \mathrm{H}), 7.12(\mathrm{~d}, J=7.9 \mathrm{~Hz}$, 1H), $7.08(\mathrm{~s}, 1 \mathrm{H}), 6.34(\mathrm{~d}, J=15.8 \mathrm{~Hz}, 1 \mathrm{H}), 5.10\left(\mathrm{~s}_{\mathrm{br}}, 1 \mathrm{H}\right), 3.79(\mathrm{~s}, 3 \mathrm{H}), 3.58(\mathrm{~s}, 2 \mathrm{H}), 2.36(\mathrm{~s}, 3 \mathrm{H}), 1.27$ (s, 9H).

${ }^{13}$ C NMR $\left(100 \mathrm{MHz}, \mathrm{CDCl}_{3}\right): \delta=169.2\left(\mathrm{C}_{\mathrm{q}}\right), 167.2\left(\mathrm{C}_{\mathrm{q}}\right), 141.5(\mathrm{CH}), 140.9\left(\mathrm{C}_{\mathrm{q}}\right), 134.8\left(\mathrm{C}_{\mathrm{q}}\right), 132.1$ $(\mathrm{CH}), 131.0\left(\mathrm{C}_{\mathrm{q}}\right), 128.8(\mathrm{CH}), 127.0(\mathrm{CH}), 119.1(\mathrm{CH}), 51.7\left(\mathrm{CH}_{3}\right), 51.4\left(\mathrm{C}_{\mathrm{q}}\right), 42.4\left(\mathrm{CH}_{2}\right), 28.6\left(\mathrm{CH}_{3}\right)$, $21.3\left(\mathrm{CH}_{3}\right)$.

IR (ATR): 2967, 1717, 1646, 1543, 1173, 1159, $816 \mathrm{~cm}^{-1}$.

MS (ESI) $m / z$ (relative intensity): $312(100)[\mathrm{M}+\mathrm{Na}]^{+}, 290(60)[\mathrm{M}+\mathrm{H}]^{+}, 258(40)$.

HR-MS (ESI) $m / z$ calcd for $\mathrm{C}_{17} \mathrm{H}_{24} \mathrm{NO}_{3}[\mathrm{M}+\mathrm{H}]^{+}: 290.1751$, found: 290.1754 . 
<smiles>CCOCC=Cc1cc([N+](=O)[O-])ccc1CC(=O)NC(C)(C)C</smiles>

\section{(E)-n-Butyl 3-\{2-[2-(tert-butylamino)-2-oxoethyl]-5-nitrophenyl\}acrylate (133wa):}

The general procedure $\mathbf{A}$ was followed using $N$-(tert-butyl)-2-(4-nitrophenyl)acetamide (132w) (118 $\mathrm{mg}, 0.50 \mathrm{mmol}$ ) and $n$-butyl acrylate (5a) $(128 \mathrm{mg}, 1.00 \mathrm{mmol})$. Isolation by column chromatography ( $n$-hexane/EtOAc: 5/1) yielded 133wa (104 mg, 65\%) as a white solid.

M. p. $=159-160{ }^{\circ} \mathrm{C}$

${ }^{1}$ H NMR $\left(300 \mathrm{MHz}, \mathrm{CDCl}_{3}\right): \delta=8.42(\mathrm{~d}, J=2.3 \mathrm{~Hz}, 1 \mathrm{H}), 8.17(\mathrm{dd}, J=8.4,2.3 \mathrm{~Hz}, 1 \mathrm{H}), 7.86(\mathrm{~d}, J=$ $15.8 \mathrm{~Hz}, 1 \mathrm{H}), 7.47(\mathrm{~d}, J=8.4 \mathrm{~Hz}, 1 \mathrm{H}), 6.50(\mathrm{~d}, J=15.8 \mathrm{~Hz}, 1 \mathrm{H}), 5.37\left(\mathrm{~s}_{\mathrm{br}}, 1 \mathrm{H}\right), 4.22(\mathrm{t}, J=6.7 \mathrm{~Hz}, 2 \mathrm{H})$, 3.67 (s, 2H), 1.71-1.65 (m, 2H), 1.48-1.40 (m, 2H), $1.32(\mathrm{~s}, 9 \mathrm{H}), 0.96(\mathrm{t}, J=7.4 \mathrm{~Hz}, 3 \mathrm{H})$.

${ }^{13}$ C NMR (125 MHz, $\left.\mathrm{CDCl}_{3}\right): \delta=166.4\left(\mathrm{C}_{\mathrm{q}}\right), 165.1\left(\mathrm{C}_{\mathrm{q}}\right), 146.4\left(\mathrm{C}_{\mathrm{q}}\right), 140.6\left(\mathrm{C}_{\mathrm{q}}\right), 138.3(\mathrm{CH}), 134.6$ $\left(\mathrm{C}_{\mathrm{q}}\right), 131.3(\mathrm{CH}), 123.2(\mathrm{CH}), 122.4(\mathrm{CH}), 120.8(\mathrm{CH}), 63.9\left(\mathrm{CH}_{2}\right), 50.9\left(\mathrm{C}_{\mathrm{q}}\right), 40.8\left(\mathrm{CH}_{2}\right), 29.7\left(\mathrm{CH}_{2}\right)$, $27.6\left(\mathrm{CH}_{3}\right), 18.1\left(\mathrm{CH}_{2}\right), 12.7\left(\mathrm{CH}_{3}\right)$.

IR (ATR): 2962, 1714, 1648, 1547, 1176, 821, $739 \mathrm{~cm}^{-1}$.

MS (ESI) $m / z$ (relative intensity): $385(100)[\mathrm{M}+\mathrm{Na}]^{+}, 363(55)[\mathrm{M}+\mathrm{H}]^{+}$.

HR-MS (ESI) $m / z$ calcd for $\mathrm{C}_{29} \mathrm{H}_{27} \mathrm{~N}_{2} \mathrm{O}_{5}[\mathrm{M}+\mathrm{H}]^{+}: 363.1914$, found: 363.1911 .<smiles>CCOC(=O)/C=C/c1ccc2ccccc2c1CC(=O)N1CCCC1</smiles>

\section{(E)-n-Butyl 3-\{1-[2-oxo-2-(pyrrolidin-1-yl)ethyl]naphthalen-2-yl\}acrylate (133xa):}

The general procedure A was followed using 2-(naphthalen-1-yl)-1-(pyrrolidin-1-yl)ethanone (132x) (120 $\mathrm{mg}, 0.50 \mathrm{mmol})$ and $n$-butyl acrylate (5a) $(128 \mathrm{mg}, 1.00 \mathrm{mmol})$. Isolation by column chromatography ( $n$-hexane/EtOAc: $5 / 1)$ yielded 133xa (110 mg, 60\%) as a white solid.

M. p. $=149-150{ }^{\circ} \mathrm{C}$. 
${ }^{1}$ H NMR $\left(300 \mathrm{MHz}, \mathrm{CDCl}_{3}\right): \delta=8.14(\mathrm{~d}, J=15.7 \mathrm{~Hz}, 1 \mathrm{H}), 7.98-7.94(\mathrm{~m}, 1 \mathrm{H}), 7.84-7.74(\mathrm{~m}, 2 \mathrm{H})$, $7.66(\mathrm{~d}, J=8.7 \mathrm{~Hz}, 1 \mathrm{H}), 7.56-7.45(\mathrm{~m}, 2 \mathrm{H}), 6.47(\mathrm{~d}, J=15.7 \mathrm{~Hz}, 1 \mathrm{H}), 4.22(\mathrm{~m}, 4 \mathrm{H}), 3.68(\mathrm{t}, J=6.8 \mathrm{~Hz}$, 2H), $3.52(\mathrm{t}, J=6.9 \mathrm{~Hz}, 2 \mathrm{H}), 2.15-2.00(\mathrm{~m}, 2 \mathrm{H}), 1.91(\mathrm{~m}, 2 \mathrm{H}), 1.71(\mathrm{ddd}, J=14.5,9.6,6.6 \mathrm{~Hz}, 2 \mathrm{H})$, 1.46 (tdd, $J=14.4,8.4,6.4 \mathrm{~Hz}, 2 \mathrm{H}), 0.98(\mathrm{t}, J=7.3 \mathrm{~Hz}, 3 \mathrm{H})$.

${ }^{13} \mathrm{C}$ NMR $\left(125 \mathrm{MHz}, \mathrm{CDCl}_{3}\right): \delta=168.0\left(\mathrm{C}_{\mathrm{q}}\right), 166.9\left(\mathrm{C}_{\mathrm{q}}\right), 142.4(\mathrm{CH}), 134.2\left(\mathrm{C}_{\mathrm{q}}\right), 132.9\left(\mathrm{C}_{\mathrm{q}}\right), 132.1$ $\left(\mathrm{C}_{\mathrm{q}}\right), 131.4\left(\mathrm{C}_{\mathrm{q}}\right), 128.5(\mathrm{CH}), 127.8(\mathrm{CH}), 126.8(\mathrm{CH}), 126.4(\mathrm{CH}), 124.7(\mathrm{CH}), 123.6(\mathrm{CH}), 120.7$ $(\mathrm{CH}), 64.3\left(\mathrm{CH}_{2}\right), 46.9\left(\mathrm{CH}_{2}\right), 46.1\left(\mathrm{CH}_{2}\right), 34.5\left(\mathrm{CH}_{2}\right), 30.8\left(\mathrm{CH}_{2}\right), 26.4\left(\mathrm{CH}_{2}\right), 24.4\left(\mathrm{CH}_{2}\right), 19.3\left(\mathrm{CH}_{2}\right)$, $13.8\left(\mathrm{CH}_{3}\right)$.

IR (ATR): 2957, 1705, 1628, 1418, 1172, 912, $727 \mathrm{~cm}^{-1}$.

MS (ESI) $m / z$ (relative intensity): $388(30)[\mathrm{M}+\mathrm{Na}]^{+}, 366(100)[\mathrm{M}+\mathrm{H}]^{+}, 292(25)$.

HR-MS (ESI) $m / z$ calcd for $\mathrm{C}_{23} \mathrm{H}_{28} \mathrm{NO}_{3}[\mathrm{M}+\mathrm{H}]^{+}: 366.2064$, found: 366.2065.<smiles>CNC(=O)Cc1c(C)cccc1/C=C/COC</smiles>

\section{(E)-Methyl 3-\{3-methyl-2-[2-(methylamino)-2-oxoethyl]phenyl\}acrylate (133yc):}

The general procedure A was followed using $N$-methyl-2-(o-tolyl)acetamide (132y) $(81.5 \mathrm{mg}, 0.50$ mmol) and methyl acrylate $(\mathbf{5 c})(86 \mathrm{mg}, 1.00 \mathrm{mmol})$. Isolation by column chromatography ( $n$-hexane/EtOAc: $5 / 1)$ yielded 133yc $(65 \mathrm{mg}, 53 \%)$ as a white solid.

M. p. $=112-113^{\circ} \mathrm{C}$.

${ }^{1}$ H NMR $\left(300 \mathrm{MHz}, \mathrm{CDCl}_{3}\right): \delta=7.90(\mathrm{~d}, J=15.7 \mathrm{~Hz}, 1 \mathrm{H}), 7.43(\mathrm{dd}, J=6.3,2.9 \mathrm{~Hz}, 1 \mathrm{H}), 7.25-7.22$ $(\mathrm{m}, 2 \mathrm{H}), 6.32(\mathrm{~d}, J=15.7 \mathrm{~Hz}, 1 \mathrm{H}), 5.20\left(\mathrm{~s}_{\mathrm{br}}, 1 \mathrm{H}\right), 3.78(\mathrm{~s}, 3 \mathrm{H}), 3.72(\mathrm{~s}, 2 \mathrm{H}), 2.72(\mathrm{~d}, J=4.8 \mathrm{~Hz}, 3 \mathrm{H})$, $2.30(\mathrm{~s}, 3 \mathrm{H})$.

${ }^{13} \mathrm{C}$ NMR $\left(125 \mathrm{MHz}, \mathrm{CDCl}_{3}\right): \delta=170.0\left(\mathrm{C}_{\mathrm{q}}\right), 166.7\left(\mathrm{C}_{\mathrm{q}}\right), 141.9(\mathrm{CH}), 138.4\left(\mathrm{C}_{\mathrm{q}}\right), 134.7\left(\mathrm{C}_{\mathrm{q}}\right), 132.5$ $\left(\mathrm{C}_{\mathrm{q}}\right), 132.3(\mathrm{CH}), 127.8(\mathrm{CH}), 125.2(\mathrm{CH}), 121.1(\mathrm{CH}), 51.8\left(\mathrm{CH}_{3}\right), 37.3\left(\mathrm{CH}_{2}\right), 26.6\left(\mathrm{CH}_{3}\right), 20.3$ $\left(\mathrm{CH}_{3}\right)$.

IR (ATR): 2950, 1718, 1644, 1599, 1316, 1164, $790 \mathrm{~cm}^{-1}$.

MS (ESI) $m / z$ (relative intensity): $270(100)[\mathrm{M}+\mathrm{Na}]^{+}, 248(15)[\mathrm{M}+\mathrm{H}]^{+}, 216(20)$.

HR-MS (ESI) $m / z$ calcd for $\mathrm{C}_{14} \mathrm{H}_{18} \mathrm{NO}_{3}[\mathrm{M}+\mathrm{H}]^{+}:$248.1281, found: 248.1280. 
<smiles>CC(C)(C)NC(=O)Cc1ccccc1C(=Cc1ccccc1)c1ccccc1</smiles>

\section{(E)-N-(tert-butyl)-2-[2-(1,2-diphenylvinyl)phenyl]acetamide (133'ic):}

The general procedure $\mathbf{B}$ was followed using $N$-(tert-butyl)-2-phenylacetamide (132i) $(95.5 \mathrm{mg}, 0.50$ mmol) and 1,2-diphenylethyne (51b) $(106 \mathrm{mg}, 1.00 \mathrm{mmol})$. Isolation by column chromatography (n-hexane/EtOAc: 5/1) yielded 133'ic (105 mg, 57\%) as a white solid.

M. p. $=135-136{ }^{\circ} \mathrm{C} .{ }^{1} \mathrm{H}$ NMR $\left(400 \mathrm{MHz}, \mathrm{CDCl}_{3}\right): \delta=7.34-7.28(\mathrm{~m}, 4 \mathrm{H}), 7.20(\mathrm{ddd}, J=5.8,2.4,1.2$ $\mathrm{Hz}, 3 \mathrm{H}), 7.17-7.12(\mathrm{~m}, 5 \mathrm{H}), 7.10-7.07$ (m, 2H), 6.59 (s, 1H), 4.85 ( $\left.\mathrm{s}_{\mathrm{br}}, 1 \mathrm{H}\right), 3.35$ (s, 2H), $1.16(\mathrm{~s}, 9 \mathrm{H})$.

${ }^{13}$ C NMR $\left(100 \mathrm{MHz}, \mathrm{CDCl}_{3}\right): \delta=170.1\left(\mathrm{C}_{\mathrm{q}}\right), 144.1\left(\mathrm{C}_{\mathrm{q}}\right), 142.0\left(\mathrm{C}_{\mathrm{q}}\right), 139.9\left(\mathrm{C}_{\mathrm{q}}\right), 136.9\left(\mathrm{C}_{\mathrm{q}}\right), 133.7\left(\mathrm{C}_{\mathrm{q}}\right)$, $131.1(\mathrm{CH}), 130.9(\mathrm{CH}), 130.9(\mathrm{CH}), 129.7(\mathrm{CH}), 129.4(\mathrm{CH}), 128.5(\mathrm{CH}), 128.1(\mathrm{CH}), 128.1(\mathrm{CH})$, 127.6 (CH), $127.1(\mathrm{CH}), 127.0(\mathrm{CH}), 51.0\left(\mathrm{CH}_{2}\right), 42.3\left(\mathrm{C}_{\mathrm{q}}\right), 28.56\left(\mathrm{CH}_{3}\right)$.

IR (ATR): 2914, 1694, 1656, 1444, 1221, 747, $696 \mathrm{~cm}^{-1}$.

MS (EI) $m / z$ (relative intensity): 369 (70) $[\mathrm{M}]^{+}, 278$ (75), $222(55)$.

HR-MS (ESI) $m / z$ calcd for $\mathrm{C}_{26} \mathrm{H}_{28} \mathrm{NO}[\mathrm{M}+\mathrm{H}]^{+}: 370.2145$, found: 370.2141 .<smiles>CC(C)(C)NC(=O)Cc1cc(Br)ccc1C(=Cc1ccc(F)cc1)c1ccc(F)cc1</smiles>

\section{(E)-2-\{2-[1,2-Bis(4-fluorophenyl)vinyl]-5-bromophenyl\}-N-(tert-butyl)acetamide (133'td):}

The general procedure $\mathbf{B}$ was followed using 2-(3-bromophenyl)- $N$-(tert-butyl)acetamide (132t) (134.5 mg, $0.50 \mathrm{mmol}$ ) and 1,2-bis(4-fluorophenyl)ethyne (51d) (128 mg, $1.00 \mathrm{mmol})$. Isolation by column chromatography ( $n$-hexane/EtOAc: $5 / 1)$ yielded 133 tdd (148 mg, 61\%) as a white solid. M. p. $=135-136{ }^{\circ} \mathrm{C}$. 
${ }^{1}$ H NMR $\left(300 \mathrm{MHz}, \mathrm{CDCl}_{3}\right): \delta=7.46(\mathrm{~d}, J=2.0 \mathrm{~Hz}, 1 \mathrm{H}), 7.40(\mathrm{dd}, J=8.3,2.1 \mathrm{~Hz}, 1 \mathrm{H}), 7.12(\mathrm{~d}, J$ $=8.0 \mathrm{~Hz}, 1 \mathrm{H}), 7.10-7.01(\mathrm{~m}, 4 \mathrm{H}), 6.94-6.83(\mathrm{~m}, 4 \mathrm{H}), 6.53(\mathrm{~s}, 1 \mathrm{H}), 4.85\left(\mathrm{~s}_{\mathrm{br}}, 1 \mathrm{H}\right), 3.25(\mathrm{~s}, 2 \mathrm{H}), 1.19$ (s, 9H).

${ }^{13} \mathrm{C}$ NMR $\left(125 \mathrm{MHz}, \mathrm{CDC}_{3}\right): \delta=168.7\left(\mathrm{C}_{\mathrm{q}}\right), 162.1\left(\mathrm{C}_{\mathrm{q}},{ }^{1} J_{\mathrm{C}-\mathrm{F}}=248.8 \mathrm{~Hz}\right), 161.7\left(\mathrm{C}_{\mathrm{q}},{ }^{1} J_{\mathrm{C}-\mathrm{F}}=247.6\right.$ $\mathrm{Hz}), 142.4\left(\mathrm{C}_{\mathrm{q}}\right), 139.6\left(\mathrm{C}_{\mathrm{q}},\right), 135.6\left(\mathrm{C}_{\mathrm{q}}\right), 135.1\left(\mathrm{C}_{\mathrm{q}},{ }^{4} J_{\mathrm{C}-\mathrm{F}}=3.8 \mathrm{~Hz}\right), 133.8(\mathrm{CH}), 132.4\left(\mathrm{C}_{\mathrm{q}},{ }^{4} J_{\mathrm{C}-\mathrm{F}}=\right.$ $3.8 \mathrm{~Hz}), 132.2(\mathrm{CH}), 131.4\left(\mathrm{CH},{ }^{3} J_{\mathrm{C}-\mathrm{F}}=8.2 \mathrm{~Hz}\right), 130.8\left(\mathrm{CH},{ }^{3} J_{\mathrm{C}-\mathrm{F}}=8.2 \mathrm{~Hz}\right), 130.3(\mathrm{CH}), 130.2(\mathrm{CH})$, $121.9\left(\mathrm{C}_{\mathrm{q}}\right), 115.7\left(\mathrm{CH},{ }^{2} J_{\mathrm{C}-\mathrm{F}}=21.5 \mathrm{~Hz}\right), 115.2\left(\mathrm{CH},{ }^{2} J_{\mathrm{C}-\mathrm{F}}=21.5 \mathrm{~Hz}\right), 51.3\left(\mathrm{CH}_{2}\right), 41.9\left(\mathrm{C}_{\mathrm{q}}\right), 28.7$ $\left(\mathrm{CH}_{3}\right)$.

${ }^{19}$ F NMR $\left(282 \mathrm{~Hz}, \mathrm{CDCl}_{3}\right): \delta=-113.81,-113.7$.

IR (ATR): 1639, 1544, 1506, 1228, 823, $548 \mathrm{~cm}^{-1}$.

MS (EI) $m / z$ (relative intensity): $485(25)\left[\mathrm{M},{ }^{81} \mathrm{Br}\right]^{+}, 374$ (20), 304 (30).

HR-MS (ESI) $m / z$ calcd for $\mathrm{C}_{26} \mathrm{H}_{25}{ }^{81} \mathrm{BrF}_{2} \mathrm{NO}[\mathrm{M}+\mathrm{H}]^{+}: 485.1013$, found: 485.1010 .<smiles>NC(=O)Cc1ccccc1C(=Cc1ccccc1)c1ccccc1</smiles>

\section{(E)-2-[2-(1,2-diphenylvinyl)phenyl]acetamide (133'ac):}

The general procedure B was followed using 2-phenylacetamide (132a) $(67.5 \mathrm{mg}, 0.50 \mathrm{mmol})$, 1,2-diphenylethyne (51b) $(106 \mathrm{mg}, 1.00 \mathrm{mmol})$ and $\left[\mathrm{RuCl}_{2}(p \text {-cymene })\right]_{2}(30.6 \mathrm{mg}, 10.0 \mathrm{~mol} \%)$ in 1,4-dioxane $(2.0 \mathrm{~mL})$. Isolation by column chromatography ( $n$-hexane/EtOAc: $5 / 1)$ yielded 133'ab (103 $\mathrm{mg}, 66 \%)$ as a white solid.

M. p. $=123-124{ }^{\circ} \mathrm{C}$.

${ }^{1}$ H NMR (400 MHz, $\left.\mathrm{CDCl}_{3}\right): \delta=7.38-7.34(\mathrm{~m}, 1 \mathrm{H}), 7.33-7.29(\mathrm{~m}, 3 \mathrm{H}), 7.22-7.18(\mathrm{~m}, 3 \mathrm{H}), 7.18-7.13$ (m, 5H), 7.12-7.08 (m, 2H), $6.63(\mathrm{~s}, 1 \mathrm{H}), 4.91\left(\mathrm{~s}_{\mathrm{br}}, 1 \mathrm{H}\right), 3.46(\mathrm{~s}, 2 \mathrm{H})$.

${ }^{13}$ C NMR $\left(100 \mathrm{MHz}, \mathrm{CDCl}_{3}\right): \delta=173.1\left(\mathrm{C}_{\mathrm{q}}\right), 144.3\left(\mathrm{C}_{\mathrm{q}}\right), 141.8\left(\mathrm{C}_{\mathrm{q}}\right), 140.0\left(\mathrm{C}_{\mathrm{q}}\right), 136.8\left(\mathrm{C}_{\mathrm{q}}\right), 133.1\left(\mathrm{C}_{\mathrm{q}}\right)$, $131.3(\mathrm{CH}), 131.1(\mathrm{CH}), 130.9(\mathrm{CH}), 129.9(\mathrm{CH}), 129.4(\mathrm{CH}), 128.6(\mathrm{CH}), 128.2(\mathrm{CH}), 128.1(\mathrm{CH})$, 127.6 (CH), $127.5(\mathrm{CH}), 127.1(\mathrm{CH}), 40.6\left(\mathrm{CH}_{2}\right)$. 
IR (ATR): 1666, 1606, 1490, 1441, 1373, 769, $698 \mathrm{~cm}^{-1}$.

MS (EI) $m / z$ (relative intensity): 313 (50) [M] ${ }^{+}, 268$ (30), 222 (65).

HR-MS (ESI) $m / z$ calcd for $\mathrm{C}_{22} \mathrm{H}_{20} \mathrm{NO}[\mathrm{M}+\mathrm{H}]^{+}: 313.1462$, found: 313.1465 . 


\section{Sythesis of $\left[D_{5}\right]-132 i$}

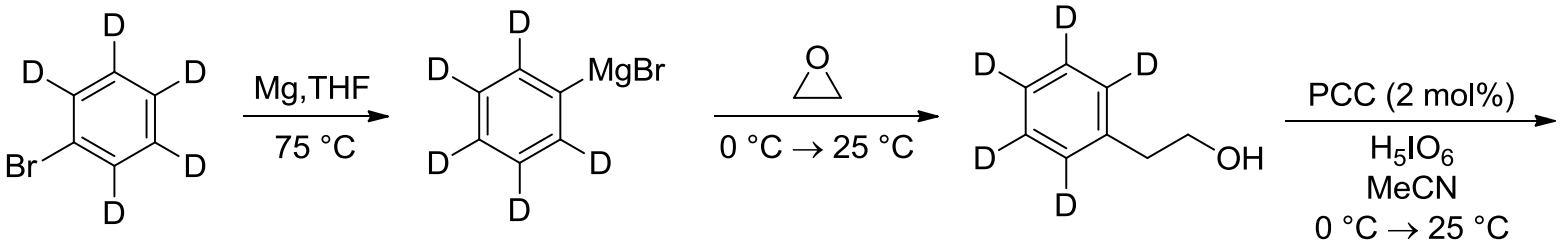<smiles>[2H]c1c([2H])c([2H])c(CC(=O)O)c([2H])c1[2H]</smiles><smiles>CO[Mg]Cc1ccccc1</smiles><smiles>[2H]c1c([2H])c([2H])c(CC(=O)Cl)c([2H])c1[2H]</smiles><smiles>[2H]c1c([2H])c([2H])c(CC(=O)NC(C)(C)C)c([2H])c1[2H]</smiles>

A solution of the $[\mathrm{D}]_{5}-\mathrm{PhMgBr}$ in $\mathrm{THF}(30 \mathrm{~mL})$ was prepared from bromobenzene- $d_{5}(1.62 \mathrm{~g}, 10$ mmol) and magnesium $(0.25 \mathrm{~g}, 10 \mathrm{mmol})$. Then, the reaction mixture was cooled to $0{ }^{\circ} \mathrm{C}$ and at $78{ }^{\circ} \mathrm{C}$ cold ethylene oxide (approx. $15 \mathrm{mmol}$ ) was added. The resulting mixture was allowed to warm to $25^{\circ} \mathrm{C}$ and then stirred for an additional $6 \mathrm{~h}$. The reaction was stopped by the addition of aq. $\mathrm{HCl}$ $(2 \mathrm{~N}, 10 \mathrm{~mL})$, the solution was extracted with $\mathrm{Et}_{2} \mathrm{O}(3 \times 20 \mathrm{~mL})$ and washed with brine $(20 \mathrm{~mL})$. The combined organic extracts were dried over $\mathrm{NaSO}_{4}$ and concentrated. Purification of the crude product by flash chromatography on silica gel ( $n$-hexane/EtOAc $10 / 1 \rightarrow 0 / 1)$ yielded 2-phenylethanol- $d_{5}(0.43 \mathrm{~g}, 34 \%){ }^{[136]}$

$\mathrm{H}_{5} \mathrm{IO}_{6}(1.37 \mathrm{~g}, 6 \mathrm{mmol})$ was dissolved in $\mathrm{MeCN}(20 \mathrm{~mL})$ and the mixture was stirred vigorously at $25{ }^{\circ} \mathrm{C}$ for $15 \mathrm{~min}$ and 2-phenylethanol- $d_{5}(0.38 \mathrm{~g}, 3.0 \mathrm{mmol})$ was added. A solution of PCC (13 mg, 2 mol \%) in $\mathrm{MeCN}(6 \mathrm{~mL})$ was then added in two portions at $0{ }^{\circ} \mathrm{C}$ and the reaction mixture was stirred at $25{ }^{\circ} \mathrm{C}$ for $3 \mathrm{~h}$. The reaction mixture was then diluted with EtOAc $(30 \mathrm{~mL})$ and washed with a mixture of brine and water $(1: 1,30 \mathrm{~mL})$, sat. aq. $\mathrm{NaHSO}_{3}$ solution $(30 \mathrm{~mL})$ and brine $(30 \mathrm{~mL})$. The solution was dried over $\mathrm{Na}_{2} \mathrm{SO}_{4}$ and concentrated to give 2-phenyl acetic acid- $d_{5}(80 \%)$.

2-Phenyl acetic acid- $d_{5}$ was converted to [ $\left.\mathrm{D}_{5}\right]$-132i following previously reported procedures. ${ }^{[137]}$ ${ }^{1} \mathrm{H}$ NMR $\left(400 \mathrm{MHz}, \mathrm{CDCl}_{3}\right): \delta=5.18\left(\mathrm{~s}_{\mathrm{br}}, 1 \mathrm{H}\right), 3.46(\mathrm{~s}, 2 \mathrm{H}), 1.26(\mathrm{~s}, 9 \mathrm{H})$. 


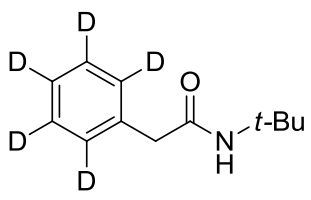

$[\mathrm{D}]_{5}-132 \mathbf{i}$

$\left(\mathrm{CDCl}_{3}, 400 \mathrm{MHz}\right)$

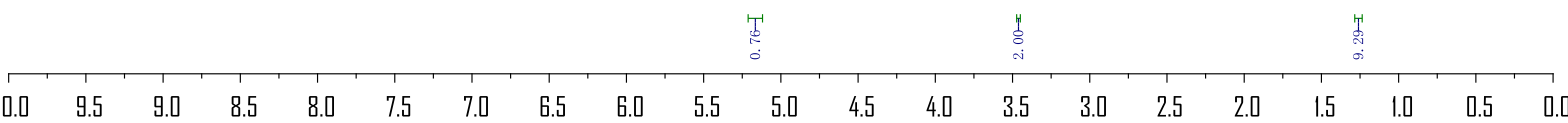

\section{Intermolecular competition experiment between amide and ketone}

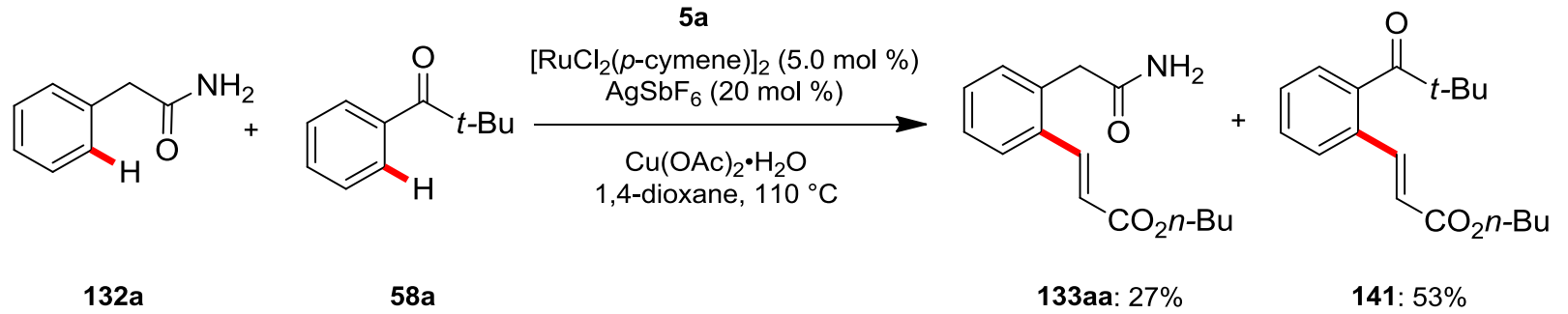

A suspension of 2-phenylacetamide (132a) $(67.5 \mathrm{mg}, 0.50 \mathrm{mmol}), 2$,2-dimethyl-1phenylpropan-1-one (58a) $(81.0 \mathrm{mg}, 0.50 \mathrm{mmol}), n$-butyl acrylate $(\mathbf{5 a})(64 \mathrm{mg}, 0.50 \mathrm{mmol}),\left[\mathrm{RuCl}_{2}(p\right.$ cymene) $]_{2}(15.3 \mathrm{mg}, 5.0 \mathrm{~mol} \%), \mathrm{AgSbF}_{6}(35.5 \mathrm{mg}, 20 \mathrm{~mol} \%)$ and $\mathrm{Cu}(\mathrm{OAc})_{2} \cdot \mathrm{H}_{2} \mathrm{O}(200 \mathrm{mg}, 1.00$ mmol) in 1,4-dioxane $(2.0 \mathrm{~mL})$ was stirred at $110{ }^{\circ} \mathrm{C}$ for $24 \mathrm{~h}$ under $\mathrm{N}_{2}$ atomsphere. Afterwards, the solvent was removed in vacuo and purification of the remaining residue by column chromatography (n-hexane/EtOAc) yieled 133aa (35 mg, 27\%) and 141 (76 mg, 53\%). 
<smiles>CCOC(=O)/C=C/c1ccccc1C(=O)C(C)(C)C</smiles>

${ }^{1}$ H NMR (300 MHz, $\left.\mathrm{CDCl}_{3}\right): \delta=7.66-7.61(\mathrm{~m}, 1 \mathrm{H}), 7.49(\mathrm{~d}, J=15.9 \mathrm{~Hz}, 1 \mathrm{H}), 7.40-7.32(\mathrm{~m}, 2 \mathrm{H})$, 7.20-7.15 (m, 1H), 6.35 (d, $J=15.9 \mathrm{~Hz}, 1 \mathrm{H}), 4.19-4.10(\mathrm{~m}, 2 \mathrm{H}), 1.71-1.56(\mathrm{~m}, 2 \mathrm{H}), 1.45-1.34(\mathrm{~m}$, 2H), 1.23-1.20 (m, 9H), $0.92(\mathrm{t}, J=7.4 \mathrm{~Hz}, 3 \mathrm{H})$.

${ }^{13} \mathrm{C}$ NMR $\left(75 \mathrm{MHz}, \mathrm{CDCl}_{3}\right): \delta=214.1\left(\mathrm{C}_{\mathrm{q}}\right), 166.3\left(\mathrm{C}_{\mathrm{q}}\right), 142.0\left(\mathrm{C}_{\mathrm{q}}\right), 141.5(\mathrm{CH}), 131.1\left(\mathrm{C}_{\mathrm{q}}\right), 129.1$ $(\mathrm{CH}), 129.0(\mathrm{CH}), 126.6(\mathrm{CH}), 125.3(\mathrm{CH}), 120.5(\mathrm{CH}), 64.5\left(\mathrm{CH}_{2}\right), 45.2\left(\mathrm{CH}_{2}\right), 30.7\left(\mathrm{CH}_{2}\right), 27.2$ $\left(\mathrm{CH}_{3}\right), 19.1\left(\mathrm{CH}_{2}\right), 13.7\left(\mathrm{CH}_{3}\right)$.

IR (ATR): 2961, 1710, 1688, 1463, 1307, 1267, 1177, 962, $758 \mathrm{~cm}^{-1}$.

MS (EI) $m / z$ (relative intensity): 288 (45) [M] $]^{+}, 231$ (50), 174 (25).

HR-MS (ESI) m/z calcd for $\mathrm{C}_{18} \mathrm{H}_{25} \mathrm{O}_{3}[\mathrm{M}+\mathrm{H}]^{+}:$289.1324, found: 289.1327.

\section{Intermolecular competition experiment between arylacetamide and benzamide}<smiles>NC(=O)Cc1ccccc1</smiles>

132a<smiles>NC(=O)c1ccccc1</smiles>

$9 a$<smiles>CCCOC(=O)/C=C/c1ccccc1CC(N)=O</smiles>

133aa: Trace<smiles>CCCOC(=O)C=Cc1ccccc1C(N)=O</smiles>

142: $39 \%$

A suspension of 2-phenylacetamide (132a) $(67.5 \mathrm{mg}, 0.50 \mathrm{mmol})$, benzamide (9a) $(60.5 \mathrm{mg}, 0.50$ mmol), $n$-butyl acrylate (5a) (64 mg, $0.50 \mathrm{mmol}),\left[\mathrm{RuCl}_{2}(p \text {-cymene) }]_{2}(15.3 \mathrm{mg}, 5.0 \mathrm{~mol} \%)\right.$, $\mathrm{AgSbF}_{6}(35.5 \mathrm{mg}, 20 \mathrm{~mol} \%)$ and $\mathrm{Cu}(\mathrm{OAc})_{2} \cdot \mathrm{H}_{2} \mathrm{O}(200 \mathrm{mg}, 1.00 \mathrm{mmol})$ in 1,4-dioxane $(2.0 \mathrm{~mL})$ was stirred at $110{ }^{\circ} \mathrm{C}$ for $24 \mathrm{~h}$ under $\mathrm{N}_{2}$ atomsphere. Afterwards, the solvent was removed in vacuo and purification of the remaining residue by column chromatography ( $n$-hexane/EtOAc) yieled 142 (48 $\mathrm{mg}, 39 \%)$. 
<smiles>CCOC(=O)/C=C/c1ccccc1C(N)=O</smiles>

${ }^{1} \mathrm{H}$ NMR $\left(400 \mathrm{MHz}, \mathrm{CDCl}_{3}\right): \delta=8.08(\mathrm{~d}, J=16.0 \mathrm{~Hz}, 1 \mathrm{H}), 7.64-7.61(\mathrm{~m}, 1 \mathrm{H}), 7.58-7.54(\mathrm{~m}, 1 \mathrm{H})$, $7.48-7.43(\mathrm{~m}, 1 \mathrm{H}), 7.40(\mathrm{td}, J=7.5,1.4 \mathrm{~Hz}, 1 \mathrm{H}), 6.39(\mathrm{~d}, J=16.0 \mathrm{~Hz}, 1 \mathrm{H}), 5.89\left(\mathrm{~s}_{\mathrm{br}}, 1 \mathrm{H}\right), 5.80\left(\mathrm{~s}_{\mathrm{br}}\right.$, $1 \mathrm{H}), 4.18(\mathrm{t}, J=6.7 \mathrm{~Hz}, 2 \mathrm{H}), 1.66(\mathrm{dq}, J=12.2,6.9 \mathrm{~Hz}, 2 \mathrm{H}), 1.46-1.35(\mathrm{~m}, 2 \mathrm{H}), 0.94(\mathrm{t}, J=7.4 \mathrm{~Hz}$, $3 \mathrm{H})$.

${ }^{13}$ C NMR $\left(100 \mathrm{MHz}, \mathrm{CDCl}_{3}\right): \delta=170.3\left(\mathrm{C}_{\mathrm{q}}\right), 166.5\left(\mathrm{C}_{\mathrm{q}}\right), 141.8(\mathrm{CH}), 135.8\left(\mathrm{C}_{\mathrm{q}}\right), 133.1\left(\mathrm{C}_{\mathrm{q}}\right), 130.8$ $(\mathrm{CH}), 129.8(\mathrm{CH}), 127.8(\mathrm{CH}), 127.3(\mathrm{CH}), 121.1(\mathrm{CH}), 64.6\left(\mathrm{CH}_{2}\right), 30.7\left(\mathrm{CH}_{2}\right), 19.2\left(\mathrm{CH}_{2}\right), 13.7$ $\left(\mathrm{CH}_{3}\right)$.

The analytical data are in accordance with previously reported data. ${ }^{[138]}$

\section{Intermolecular competition experiment between primary and secondary amide}

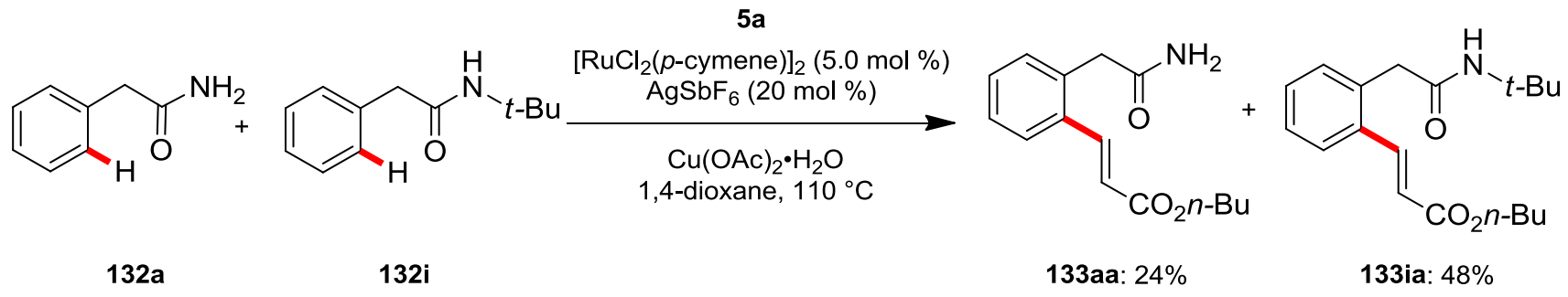

A suspension of 2-phenylacetamide (132a) $(67.5 \mathrm{mg}, 0.50 \mathrm{mmol}), \mathrm{N}$-(tert-butyl)-2-phenylacetamide (132i) (95.5 mg, $0.50 \mathrm{mmol}), n$-butyl acrylate (5a) $(64 \mathrm{mg}, 0.50 \mathrm{mmol}),\left[\mathrm{RuCl}_{2}(p \text {-cymene) }]_{2}(15.3\right.$ $\mathrm{mg}, 5.0 \mathrm{~mol} \%), \mathrm{AgSbF}_{6}(35.5 \mathrm{mg}, 20 \mathrm{~mol} \%)$ and $\mathrm{Cu}(\mathrm{OAc})_{2} \cdot \mathrm{H}_{2} \mathrm{O}(200 \mathrm{mg}, 1.00 \mathrm{mmol})$ in 1,4-dioxane $(2.0 \mathrm{~mL})$ was stirred at $110{ }^{\circ} \mathrm{C}$ for $24 \mathrm{~h}$ under $\mathrm{N}_{2}$ atomsphere. Afterwards, the solvent was removed in vacuo and purification of the remaining residue by column chromatography (n-hexane/EtOAc) yieled 133aa (31 mg, 24\%) and 133ia (76 mg, 48\%). 


\section{Intermolecular competition experiment between electron-rich and electron-deficient amide}

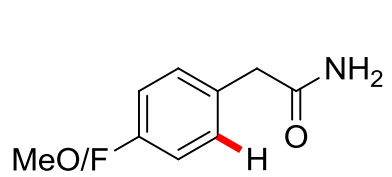

$132 \mathrm{~d} / 132$
$5 a$

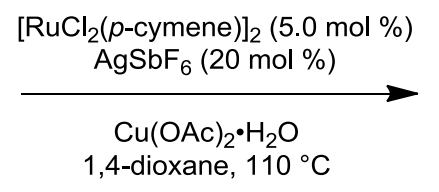

1,4-dioxane, $110^{\circ} \mathrm{C}$

133da: $17 \%$

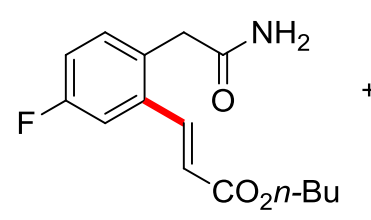<smiles>CCOC(=O)/C=C/c1cc(OC)ccc1CC(N)=O</smiles>

133ia: $44 \%$

A suspension of 2-(4-fluorophenyl)acetamide $\quad(\mathbf{1 3 2 d}) \quad(76.5 \quad \mathrm{mg}, \quad 0.50 \quad \mathrm{mmol})$, 2-(4-methoxyphenyl)acetamide (132i) $(82.5 \mathrm{mg}, 0.50 \mathrm{mmol}), n$-butyl acrylate (5a) (64 mg, 0.50 mmol), $\left[\mathrm{RuCl}_{2}(p \text {-cymene) }]_{2}(15.3 \mathrm{mg}, 5.0 \mathrm{~mol} \%), \mathrm{AgSbF}_{6}(35.5 \mathrm{mg}, 20 \mathrm{~mol} \%)\right.$ and $\mathrm{Cu}(\mathrm{OAc})_{2} \cdot \mathrm{H}_{2} \mathrm{O}$ (200 mg, $1.00 \mathrm{mmol})$ in 1,4-dioxane $(2.0 \mathrm{~mL})$ was stirred at $110{ }^{\circ} \mathrm{C}$ for $24 \mathrm{~h}$ under $\mathrm{N}_{2}$ atomsphere. Afterwards, the solvent was removed in vacuo and purification of the remaining residue by column chromatography ( $n$-hexane/EtOAc) yieled 133da (24 mg, 17\%) and 133ia (64 mg, 44\%).<smiles>COC(=O)/C=C/c1cc(OC)ccc1CC(N)=O</smiles>

M. p. $=129-130^{\circ} \mathrm{C}$.

${ }^{1}$ H NMR $\left(300 \mathrm{MHz}, \mathrm{CDCl}_{3}\right): \delta=7.82(\mathrm{~d}, J=15.7 \mathrm{~Hz}, 1 \mathrm{H}), 7.16(\mathrm{t}, J=8.0 \mathrm{~Hz}, 1 \mathrm{H}), 7.07(\mathrm{~d}, J=2.6 \mathrm{~Hz}$, $1 \mathrm{H}), 6.88(\mathrm{dd}, J=8.4,2.5 \mathrm{~Hz}, 1 \mathrm{H}), 6.37-6.28(\mathrm{~m}, 1 \mathrm{H}), 5.96(\mathrm{~d}, J=15.9 \mathrm{~Hz}, 1 \mathrm{H}), 5.57(\mathrm{~s}, 1 \mathrm{H}), 4.16(\mathrm{t}$, $J=6.7 \mathrm{~Hz}, 2 \mathrm{H}), 3.79(\mathrm{~s}, 3 \mathrm{H}), 3.61(\mathrm{~s}, 2 \mathrm{H}), 1.65(\mathrm{dt}, J=14.7,6.8 \mathrm{~Hz}, 2 \mathrm{H}), 1.39(\mathrm{dq}, J=14.4,7.3 \mathrm{~Hz}$, $2 \mathrm{H}), 0.98-0.88(\mathrm{~m}, 3 \mathrm{H})$.

${ }^{13}$ C NMR (125 MHz, $\left.\mathrm{CDCl}_{3}\right): \delta=172.8\left(\mathrm{C}_{\mathrm{q}}\right), 166.5\left(\mathrm{C}_{\mathrm{q}}\right), 159.0\left(\mathrm{C}_{\mathrm{q}}\right), 141.1(\mathrm{CH}), 134.9\left(\mathrm{C}_{\mathrm{q}}\right), 132.3$ $(\mathrm{CH}), 126.5\left(\mathrm{C}_{\mathrm{q}}\right), 121.0(\mathrm{CH}), 116.4(\mathrm{CH}), 111.8(\mathrm{CH}), 64.6\left(\mathrm{CH}_{2}\right), 55.4\left(\mathrm{CH}_{3}\right), 34.0\left(\mathrm{CH}_{2}\right), 30.8$ $\left(\mathrm{CH}_{2}\right), 19.2\left(\mathrm{CH}_{2}\right), 13.8\left(\mathrm{CH}_{3}\right)$.

IR (ATR): 2965, 1705, 1654, 1312, 1264, 1176, $728 \mathrm{~cm}^{-1}$.

MS (ESI) $m / z$ (relative intensity): $314(100)[\mathrm{M}+\mathrm{Na}]^{+}, 292(20)[\mathrm{M}+\mathrm{H}]^{+}$.

HR-MS (ESI) $m / z$ calcd for $\mathrm{C}_{16} \mathrm{H}_{22} \mathrm{NO}_{4}[\mathrm{M}+\mathrm{H}]^{+}: 292.1545$, found: 292.1542 . 


\section{H/D Exchange Experiments}

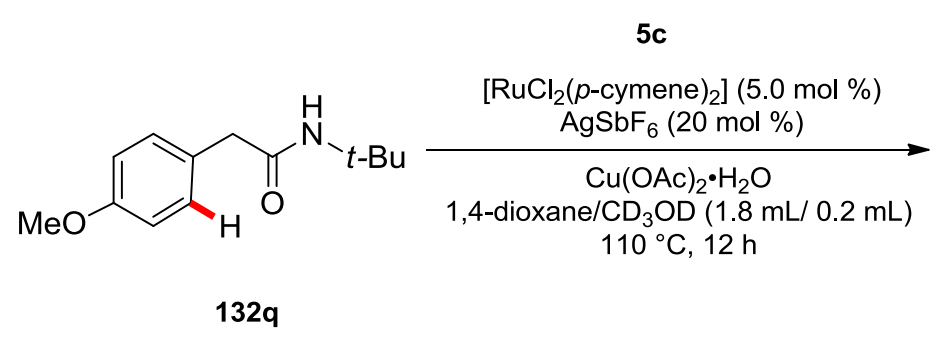

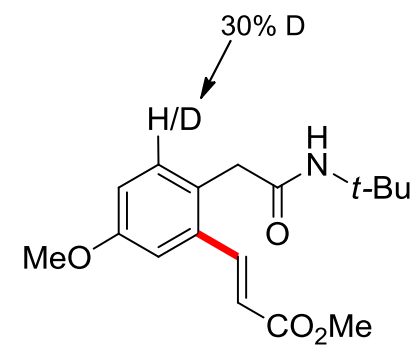

$[D]_{n}-133 q c: 60 \%$

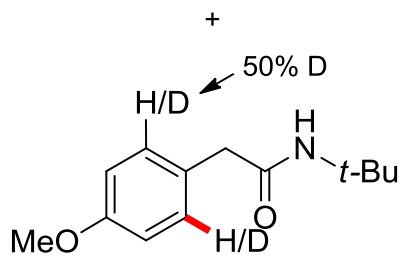

$[D]_{n}-132 q: 35 \%$

The representative procedure $B$ was followed using $\mathbf{1 3 2 q}(111 \mathrm{mg}, 0.50 \mathrm{mmol}), \mathbf{5 c}(86 \mathrm{mg}, 1.0$ mmol), $\left[\mathrm{RuCl}_{2}(p\right.$-cymene)] (15.3 mg, $5.0 \mathrm{~mol} \%), \mathrm{AgSbF}_{6}(35.5 \mathrm{mg}, 20 \mathrm{~mol} \%)$ and $\mathrm{Cu}(\mathrm{OAc})_{2} \cdot \mathrm{H}_{2} \mathrm{O}$ (200 mg, $1.0 \mathrm{mmol})$ in 1,4-dioxane $(1.8 \mathrm{~mL})$ and $\mathrm{CD}_{3} \mathrm{OD}(0.2 \mathrm{~mL})$. Purification by column chromatography ( $n$-hexane/EtOAc: $10 / 1 \rightarrow 5 / 1)$ yielded $[\mathrm{D}]_{n}-\mathbf{1 3 3 q c}(91.5 \mathrm{mg}, 60 \%)$ as a colorless solid and reisolated starting material $[\mathrm{D}]_{n} \mathbf{- 1 3 2 q}(38.9 \mathrm{mg}, 35 \%)$. The deuterium content was determinded by NMR spectroscopy. 


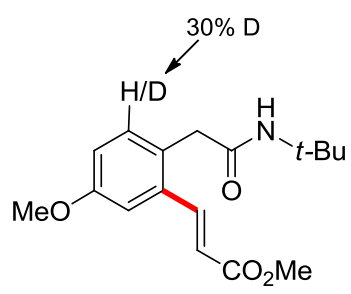

$[\mathrm{D}]_{n}-133 q \mathrm{c}$

$\left(\mathrm{CDCl}_{3}, 600 \mathrm{MHz}\right)$
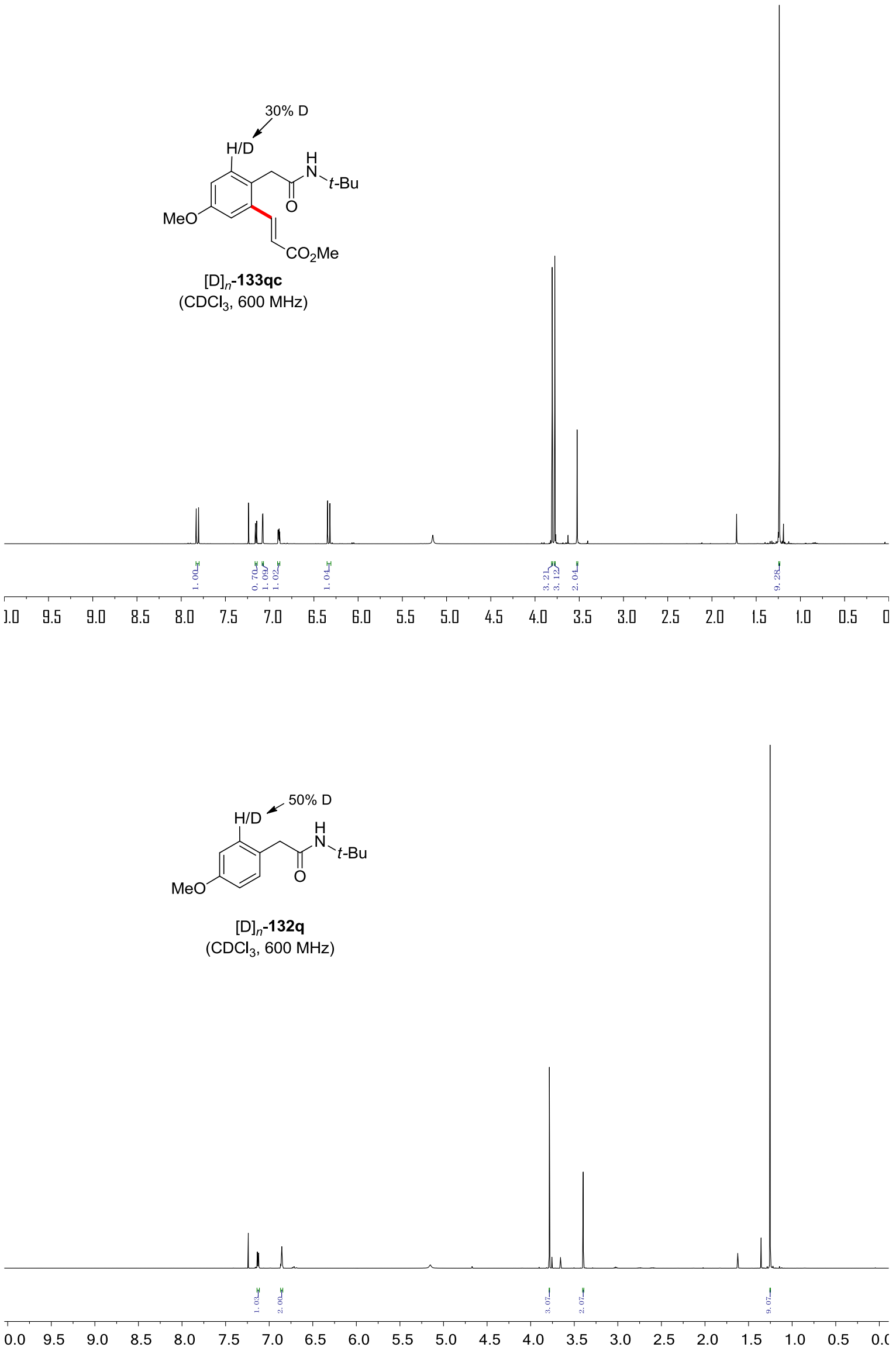


\section{Kinetic Isotope Effect (KIE) Studies}

Under an atmosphere of nitrogen 132i $(143 \mathrm{mg}, 0.75 \mathrm{mmol})$ or $[\mathrm{D}]_{5}-\mathbf{1 3 2 i}(147 \mathrm{mg}, 0.75 \mathrm{mmol})$, 5a (192 mg, $1.50 \mathrm{mmol}),\left[\mathrm{RuCl}_{2}(p \text {-cymene })\right]_{2}(23 \mathrm{mg}, 5.0 \mathrm{~mol} \%), \operatorname{AgSbF}_{6}(52 \mathrm{mg}, 20 \mathrm{~mol} \%)$ and $\mathrm{Cu}(\mathrm{OAc})_{2} \cdot \mathrm{H}_{2} \mathrm{O}(299 \mathrm{mg}, 1.50 \mathrm{mmol})$ were dissolved in 1,4-dioxane $(3.0 \mathrm{~mL})$ and stirred at $100{ }^{\circ} \mathrm{C}$. For the first $2 \mathrm{~h}$ an in situ IR spectrum was acquired every $30 \mathrm{~s}$, for the following $4 \mathrm{~h}$ one spectrum was acquired every $1 \mathrm{~min}$ and for the remaining $16 \mathrm{~h}$ one spectrum was acquired every $2 \mathrm{~min}$.

The KIE was determined by measuring initial rates from the increase of the peak at $1726 \mathrm{~cm}^{-1}$, which corresponds to a $\mathrm{C}=\mathrm{O}$ vibration of product 133ia. The absolute peak area was measured from 1744 to $1701 \mathrm{~cm}^{-1}$ with a one-point baseline at $871 \mathrm{~cm}^{-1}$. A linear fit was employed to derive the initial rates.
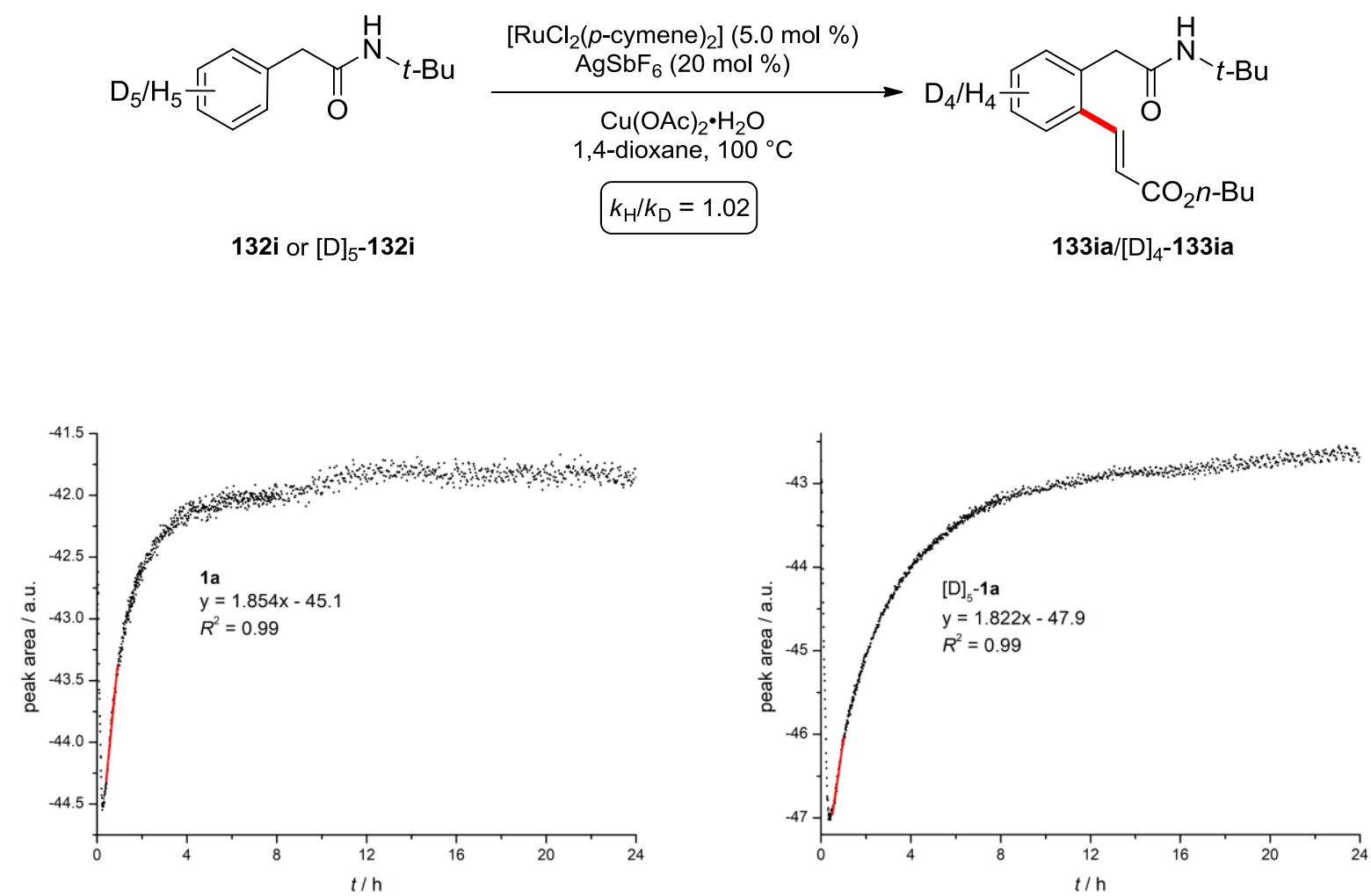

Figure xx. Plot of peak area at $1726 \mathrm{~cm}^{-1}$ vs reaction time for $\mathbf{1 3 2 i}$ (left) and $[\mathrm{D}]_{5}-\mathbf{1 3 2 i}$ (right). 


\subsubsection{Ruthenium-Catalyzed $\mathrm{C}-\mathrm{H}$ Oxygenation}

\section{Analytical Data}<smiles>CC(C)(C)NC(=O)Cc1ccccc1O</smiles>

\section{$N$-(tert-butyl)-2-(2-hydroxyphenyl)acetamide (135ia):}

The general procedure $\mathbf{C}$ was followed using $N$-(tert-butyl)-2-phenylacetamide (132i) $(95.5 \mathrm{mg}, 0.50$ mmol $), \mathrm{PhI}(\mathrm{TFA})_{2}(430 \mathrm{mg}, 1.00 \mathrm{mmol})$ and $\left[\mathrm{RuCl}_{2}(p \text {-cymene })\right]_{2}(15.3 \mathrm{mg}, 5.0 \mathrm{~mol} \%)$ in DCE $(2.0$ $\mathrm{mL}$ ). Isolation by column chromatography ( $n$-hexane/EtOAc: $5 / 1)$ yielded 135ia $(64.2 \mathrm{mg}, 62 \%)$ as a white solid.

M.p. $=125-126^{\circ} \mathrm{C}$.

${ }^{1}$ H NMR (300 MHz, $\left.\mathrm{CDCl}_{3}\right): \delta=10.25\left(\mathrm{~s}_{\mathrm{br}}, 1 \mathrm{H}\right), 7.20(\mathrm{~m}, 1 \mathrm{H}), 7.03-6.97(\mathrm{~m}, 2 \mathrm{H}), 6.84(\mathrm{t}, J=7.4 \mathrm{~Hz}$, $1 \mathrm{H}), 5.89\left(\mathrm{~s}_{\mathrm{br}}, 1 \mathrm{H}\right), 3.51(\mathrm{~s}, 2 \mathrm{H}), 1.37(\mathrm{~s}, 9 \mathrm{H})$.

${ }^{13}$ C NMR (75 MHz, $\left.\mathrm{CDCl}_{3}\right): \delta=173.1\left(\mathrm{C}_{\mathrm{q}}\right), 156.6\left(\mathrm{C}_{\mathrm{q}}\right), 130.4(\mathrm{CH}), 129.0(\mathrm{CH}), 121.9\left(\mathrm{C}_{\mathrm{q}}\right), 120.1$ $(\mathrm{CH}), 118.1(\mathrm{CH}), 52.2\left(\mathrm{C}_{\mathrm{q}}\right), 42.4\left(\mathrm{CH}_{2}\right), 28.6\left(\mathrm{CH}_{3}\right)$.

IR (ATR): 1632, 1555, 1492, 1355, 1057, 942, $797 \mathrm{~cm}^{-1}$.

MS (EI) $m / z$ (relative intensity): 207 (40) [M] $]^{+}, 134$ (65), 108 (70).

HR-MS (EI) $m / z$ calcd for $\mathrm{C}_{12} \mathrm{H}_{17} \mathrm{NO}_{2}{ }^{+}[\mathrm{M}]^{+}:$207.1259, found: 207.1261.<smiles>CCCCCCCCCC(=O)NCc1ccccc1O</smiles>

\section{n-Butyl-2-(2-hydroxyphenyl)acetamide (135ja):}

The general procedure $\mathbf{C}$ was followed using $n$-butyl-2-phenylacetamide (132j) (95.5 $\mathrm{mg}, 0.50$ mmol $), \mathrm{PhI}(\mathrm{TFA})_{2}(430 \mathrm{mg}, 1.00 \mathrm{mmol})$ and $\left[\mathrm{RuCl}_{2}(p \text {-cymene })\right]_{2}(15.3 \mathrm{mg}, 5.0 \mathrm{~mol} \%)$ in DCE $(2.0$ $\mathrm{mL}$ ). Isolation by column chromatography ( $n$-hexane/EtOAc: $5 / 1)$ yielded $\mathbf{1 3 5 j a}(73.5 \mathrm{mg}, 71 \%)$ as a white solid.

M.p. $=130-131{ }^{\circ} \mathrm{C}$. 
${ }^{1}$ H NMR $\left(300 \mathrm{MHz}, \mathrm{CDCl}_{3}\right): \delta=9.98\left(\mathrm{~s}_{\mathrm{br}}, 1 \mathrm{H}\right), 7.19(\mathrm{td}, J=7.9,1.7 \mathrm{~Hz}, 1 \mathrm{H}), 7.05-6.97(\mathrm{~m}, 2 \mathrm{H}), 6.84$ $(\mathrm{td}, J=7.4,1.2 \mathrm{~Hz}, 1 \mathrm{H}), 6.24\left(\mathrm{~s}_{\mathrm{br}}, 1 \mathrm{H}\right), 3.58(\mathrm{~s}, 2 \mathrm{H}), 3.26(\mathrm{td}, J=7.1,5.9 \mathrm{~Hz}, 2 \mathrm{H}), 1.57-1.44(\mathrm{~m}, 2 \mathrm{H})$, $1.41-1.26(\mathrm{~m}, 2 \mathrm{H}), 0.92(\mathrm{t}, J=7.3 \mathrm{~Hz}, 3 \mathrm{H})$.

${ }^{13} \mathrm{C}$ NMR $\left(75 \mathrm{MHz}, \mathrm{CDCl}_{3}\right): \delta=173.4\left(\mathrm{C}_{\mathrm{q}}\right), 156.2\left(\mathrm{C}_{\mathrm{q}}\right), 130.5(\mathrm{CH}), 129.1(\mathrm{CH}), 121.6\left(\mathrm{C}_{\mathrm{q}}\right), 120.3$ $(\mathrm{CH}), 117.9(\mathrm{CH}), 41.1\left(\mathrm{CH}_{2}\right), 39.9\left(\mathrm{CH}_{2}\right), 31.3\left(\mathrm{CH}_{2}\right), 20.0\left(\mathrm{CH}_{2}\right), 13.7\left(\mathrm{CH}_{3}\right)$.

IR (ATR): 1630, 1542, 1488, 1299, 1057, $966 \mathrm{~cm}^{-1}$.

MS (EI) $m / z$ (relative intensity): 207 (70) [M] $]^{+}, 134$ (50), 108 (100).

HR-MS (EI) $m / z$ calcd for $\mathrm{C}_{12} \mathrm{H}_{17} \mathrm{NO}_{2}{ }^{+}[\mathrm{M}]^{+}:$:207.1259, found: 207.1258 .<smiles>CC(NC(=O)Cc1ccccc1O)c1ccccc1</smiles>

\section{(R)-2-(2-hydroxyphenyl)- $N$-(1-phenylethyl)acetamide (135na):}

The general procedure $\mathbf{C}$ was followed using (R)-2-phenyl- $N$-(1-phenylethyl)acetamide (132n) (119.5 mg, $0.50 \mathrm{mmol}), \mathrm{PhI}(\mathrm{TFA})_{2}(430 \mathrm{mg}, 1.00 \mathrm{mmol})$ and $\left[\mathrm{RuCl}_{2}(p \text {-cymene })\right]_{2}(15.3 \mathrm{mg}, 5.0$ mol \%) in DCE $(2.0 \mathrm{~mL}$ ). Isolation by column chromatography ( $n$-hexane/EtOAc: 5/1) yielded 135na (80.3 mg, 63\%) as a white solid.

M.p. $=140-141^{\circ} \mathrm{C}$.

${ }^{1}$ H NMR $\left(400 \mathrm{MHz}, \mathrm{CDCl}_{3}\right): \delta=9.77\left(\mathrm{~s}_{\mathrm{br}}, 1 \mathrm{H}\right), 7.31(\mathrm{~m}, 2 \mathrm{H}), 7.28-7.24(\mathrm{~m}, 3 \mathrm{H}), 7.20-7.11(\mathrm{~m}, 1 \mathrm{H})$, $6.96(\mathrm{~m}, 2 \mathrm{H}), 6.83-6.77(\mathrm{~m}, 1 \mathrm{H}), 6.27\left(\mathrm{~s}_{\mathrm{br}}, 1 \mathrm{H}\right), 5.06(\mathrm{~m}, 1 \mathrm{H}), 3.61-3.46(\mathrm{~m}, 2 \mathrm{H}), 1.47$ (d, J = 6.9 Hz, $3 \mathrm{H})$.

${ }^{13}$ C NMR $\left(100 \mathrm{MHz}, \mathrm{CDCl}_{3}\right): \delta=172.5\left(\mathrm{C}_{\mathrm{q}}\right), 156.2\left(\mathrm{C}_{\mathrm{q}}\right), 142.2\left(\mathrm{C}_{\mathrm{q}}\right), 130.4(\mathrm{CH}), 129.2(\mathrm{CH}), 128.8$ $(\mathrm{CH}), 127.7(\mathrm{CH}), 126.1(\mathrm{CH}), 121.4\left(\mathrm{C}_{\mathrm{q}}\right), 120.2(\mathrm{CH}), 118.1(\mathrm{CH}), 49.5(\mathrm{CH}), 41.2\left(\mathrm{CH}_{2}\right), 21.4$ $\left(\mathrm{CH}_{3}\right)$.

IR (ATR): 1635, 1521, 1438, 1219, 1059, $734 \mathrm{~cm}^{-1}$.

MS (EI) $m / z$ (relative intensity): 255 (30) [M] $]^{+}, 178$ (45), 108 (70).

HR-MS (EI) $m / z$ calcd for $\mathrm{C}_{16} \mathrm{H}_{17} \mathrm{NO}_{2}{ }^{+}[\mathrm{M}]^{+}: 255.1259$, found: 255.1257 .

HPLC ( $n$-hexane/EtOAc: 80/20): $t=14.39 \mathrm{~min}$. 

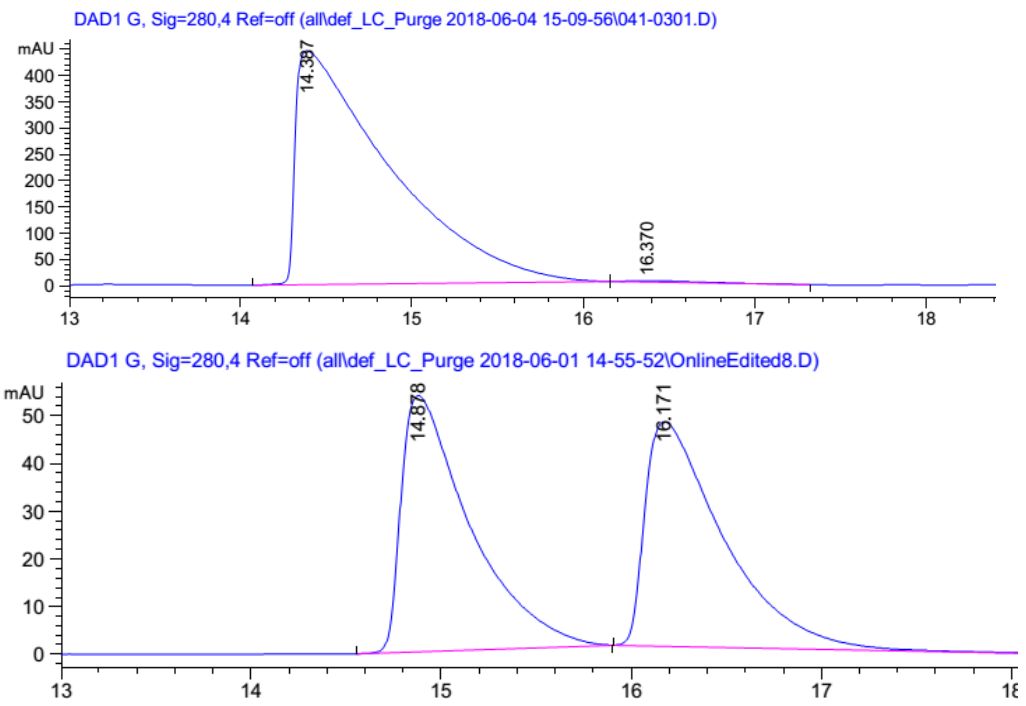<smiles>CC(=O)OCCCNC(=O)Cc1ccccc1O</smiles>

\section{3-\{2-(2-hydroxyphenyl)acetamido\}propyl acetate (1350a):}

The general procedure $\mathbf{C}$ was followed using 3-(2-phenylacetamido)propyl acetate (132o) (117.5 mg, $0.50 \mathrm{mmol}), \mathrm{PhI}(\mathrm{TFA})_{2}(430 \mathrm{mg}, 1.00 \mathrm{mmol})$ and $\left[\mathrm{RuCl}_{2}(p \text {-cymene })\right]_{2}(15.3 \mathrm{mg}, 5.0 \mathrm{~mol} \%)$ in DCE $(2.0 \mathrm{~mL})$. Isolation by column chromatography ( $n$-hexane/EtOAc: $5 / 1)$ yielded $\mathbf{1 3 5 0 a}(80.3 \mathrm{mg}, 64 \%)$ as a colorless oil.

${ }^{1}$ H NMR $\left(300 \mathrm{MHz}, \mathrm{CDCl}_{3}\right): \delta=9.66\left(\mathrm{~s}_{\mathrm{br}}, 1 \mathrm{H}\right), 7.18-7.12(\mathrm{~m}, 1 \mathrm{H}), 7.02-6.91(\mathrm{~m}, 2 \mathrm{H}), 6.83-6.77(\mathrm{~m}$, $1 \mathrm{H}), 5.66\left(\mathrm{~s}_{\mathrm{br}}, 1 \mathrm{H}\right), 4.13-4.06(\mathrm{~m}, 2 \mathrm{H}), 3.53(\mathrm{~s}, 2 \mathrm{H}), 3.31-3.24(\mathrm{~m}, 2 \mathrm{H}), 2.06-2.01(\mathrm{~m}, 2 \mathrm{H}), 1.84-1.76$ $(\mathrm{m}, 3 \mathrm{H})$.

${ }^{13} \mathrm{C}$ NMR $\left(125 \mathrm{MHz}, \mathrm{CDCl}_{3}\right): \delta=173.2\left(\mathrm{C}_{\mathrm{q}}\right), 171.3\left(\mathrm{C}_{\mathrm{q}}\right), 156.0\left(\mathrm{C}_{\mathrm{q}}\right), 130.3(\mathrm{CH}), 129.1(\mathrm{CH}), 121.4$ $\left(\mathrm{C}_{\mathrm{q}}\right), 120.2(\mathrm{CH}), 117.9(\mathrm{CH}), 61.7\left(\mathrm{CH}_{2}\right), 41.1\left(\mathrm{CH}_{2}\right), 36.7\left(\mathrm{CH}_{2}\right), 28.4\left(\mathrm{CH}_{2}\right), 21.0\left(\mathrm{CH}_{3}\right)$.

IR (ATR): 1637, 1541, 1366, 1236, 1041, $754 \mathrm{~cm}^{-1}$.

MS (EI) $m / z$ (relative intensity): 251 (30) [M] ${ }^{+}, 191$ (25), 134 (40).

HR-MS (EI) $m / z$ calcd for $\mathrm{C}_{13} \mathrm{H}_{17} \mathrm{NO}_{4}{ }^{+}[\mathrm{M}]^{+}: 251.1158$, found: 251.1158 . 
<smiles>Cc1ccc(CC(=O)NC(C)(C)C)c(O)c1</smiles>

\section{$N$-(tert-butyl)-2-(2-hydroxy-4-methylphenyl)acetamide (135za):}

The general procedure $\mathbf{C}$ was followed using $N$-(tert-butyl)-2-(p-tolyl)acetamide (132z) (102.5 mg, $0.50 \mathrm{mmol}), \mathrm{PhI}(\mathrm{TFA})_{2}(430 \mathrm{mg}, 1.00 \mathrm{mmol})$ and $\left[\mathrm{RuCl}_{2}(p \text {-cymene })\right]_{2}(15.3 \mathrm{mg}, 5.0 \mathrm{~mol} \%)$ in DCE $(2.0 \mathrm{~mL}$ ). Isolation by column chromatography ( $n$-hexane/EtOAc: $5 / 1)$ yielded 135za (56.4 mg, $51 \%$ ) as a white solid.

M.p. $=118-119^{\circ} \mathrm{C}$.

${ }^{1} \mathbf{H}$ NMR $\left(300 \mathrm{MHz}, \mathrm{CDCl}_{3}\right): \delta=10.04\left(\mathrm{~s}_{\mathrm{br}}, 1 \mathrm{H}\right), 6.83(\mathrm{~d}, J=7.6 \mathrm{~Hz}, 1 \mathrm{H}), 6.78(\mathrm{~d}, J=0.8 \mathrm{~Hz}, 1 \mathrm{H})$, 6.61 (ddd, $J=7.6,1.7,0.8 \mathrm{~Hz}, 1 \mathrm{H}), 5.64(\mathrm{sbr}, 1 \mathrm{H}), 3.41$ (s, 2H), 2.26 (s, 3H), 1.33 (s, 9H).

${ }^{13} \mathrm{C}$ NMR $\left(125 \mathrm{MHz}, \mathrm{CDCl}_{3}\right): \delta=173.0\left(\mathrm{C}_{\mathrm{q}}\right), 156.3\left(\mathrm{C}_{\mathrm{q}}\right), 139.0\left(\mathrm{C}_{\mathrm{q}}\right), 129.9(\mathrm{CH}), 120.6(\mathrm{CH}), 118.8$ $(\mathrm{CH}), 118.6\left(\mathrm{C}_{\mathrm{q}}\right), 52.2\left(\mathrm{C}_{\mathrm{q}}\right), 42.3\left(\mathrm{CH}_{2}\right), 28.6\left(\mathrm{CH}_{3}\right), 21.2\left(\mathrm{CH}_{3}\right)$.

IR (ATR): 1641, 1548, 1364, 1222, 909, $733 \mathrm{~cm}^{-1}$.

MS (EI) $m / z$ (relative intensity): $221(25)[\mathrm{M}]^{+}, 148(50), 120(70)$.

HR-MS (EI) $m / z$ calcd for $\mathrm{C}_{13} \mathrm{H}_{19} \mathrm{NO}_{2}{ }^{+}[\mathrm{M}]^{+}: 221.1416$, found: 221.1413 .<smiles>CC(C)(C)NC(=O)Cc1cc(-c2ccccc2)ccc1O</smiles>

\section{$N$-(tert-Butyl)-2-(4-hydroxy-[1,1'-biphenyl]-3-yl)acetamide (135ua):}

The general procedure $\mathbf{C}$ was followed using 2-([1,1'-biphenyl]-3-yl)- $N$-(tert-butyl)acetamide (132u) (133.5 mg, $0.50 \mathrm{mmol}), \mathrm{PhI}(\mathrm{TFA})_{2}(430 \mathrm{mg}, 1.00 \mathrm{mmol})$ and $\left[\mathrm{RuCl}_{2}(p \text {-cymene })\right]_{2}(15.3 \mathrm{mg}, 5.0$ mol \%) in DCE $(2.0 \mathrm{~mL})$. Isolation by column chromatography ( $n$-hexane/EtOAc: 5/1) yielded 135ua (75 $\mathrm{mg}, 53 \%)$ as a white solid.

M.p. $=145-146^{\circ} \mathrm{C}$.

${ }^{1} \mathbf{H}$ NMR $\left(300 \mathrm{MHz}, \mathrm{CDCl}_{3}\right): \delta=10.45\left(\mathrm{~s}_{\mathrm{br}}, 1 \mathrm{H}\right), 7.55(\mathrm{~d}, J=1.6 \mathrm{~Hz}, 1 \mathrm{H}), 7.53(\mathrm{dd}, J=3.0,1.6 \mathrm{~Hz}$, 1H), $7.44(\mathrm{~m}, 3 \mathrm{H}), 7.34-7.27(\mathrm{~m}, 1 \mathrm{H}), 7.25(\mathrm{~d}, J=2.6 \mathrm{~Hz}, 1 \mathrm{H}), 7.07(\mathrm{~d}, J=8.4 \mathrm{~Hz}, 1 \mathrm{H}), 5.92\left(\mathrm{~s}_{\mathrm{br}}, \mathrm{H}\right)$, $3.58(\mathrm{~s}, 2 \mathrm{H}), 1.39(\mathrm{~s}, 9 \mathrm{H})$. 
${ }^{13}$ C NMR (75 MHz, $\left.\mathrm{CDCl}_{3}\right): \delta=173.0\left(\mathrm{C}_{\mathrm{q}}\right), 156.2\left(\mathrm{C}_{\mathrm{q}}\right), 140.8\left(\mathrm{C}_{\mathrm{q}}\right), 133.2\left(\mathrm{C}_{\mathrm{q}}\right), 129.2(\mathrm{CH}), 128.7$ $(\mathrm{CH}), 127.7(\mathrm{CH}), 126.7(\mathrm{CH}), 126.6(\mathrm{CH}), 122.1\left(\mathrm{C}_{\mathrm{q}}\right), 118.5(\mathrm{CH}), 52.2\left(\mathrm{C}_{\mathrm{q}}\right), 42.7\left(\mathrm{CH}_{2}\right), 28.6\left(\mathrm{CH}_{3}\right)$. IR (ATR): 1643, 1556, 1483, 1357, 1054, 964, $826 \mathrm{~cm}^{-1}$.

MS (EI) $m / z$ (relative intensity): $283(20)[\mathrm{M}]^{+}, 210$ (100), 182 (70).

HR-MS (EI) $m / z$ calcd for $\mathrm{C}_{18} \mathrm{H}_{21} \mathrm{NO}_{2}{ }^{+}[\mathrm{M}]^{+}:$283.1572, found: 283.1569 .<smiles>CC(C)(C)NC(=O)Cc1ccc(F)cc1O</smiles>

\section{$N$-(tert-Butyl)-2-(4-fluoro-2-hydroxyphenyl)acetamide (135pa):}

The general procedure $\mathbf{C}$ was followed using $N$-(tert-butyl)-2-(4-fluorophenyl)acetamide (132p) (104.5 mg, $0.50 \mathrm{mmol}), \mathrm{PhI}(\mathrm{TFA})_{2}(430 \mathrm{mg}, 1.00 \mathrm{mmol})$ and $\left[\mathrm{RuCl}_{2}(p \text {-cymene })\right]_{2}(15.3 \mathrm{mg}, 5.0$ mol \%) in DCE $(2.0 \mathrm{~mL})$. Isolation by column chromatography ( $n$-hexane/EtOAc: $5 / 1)$ yielded 135pa (70.9 $\mathrm{mg}, 63 \%)$ as a white solid.

M.p. $=115-116^{\circ} \mathrm{C}$.

${ }^{1}$ H NMR (300 MHz, $\left.\mathrm{CDCl}_{3}\right): \delta=10.71\left(\mathrm{~s}_{\mathrm{br}}, 1 \mathrm{H}\right), 6.93(\mathrm{t}, J=8.3,1 \mathrm{H}), 6.70(\mathrm{dd}, J=10.4,2.6 \mathrm{~Hz}, 1 \mathrm{H})$, $6.53(\mathrm{td}, J=8.3,2.6 \mathrm{~Hz}, 1 \mathrm{H}), 5.83(\mathrm{~s} \mathrm{br}, 1 \mathrm{H}), 3.46(\mathrm{~s}, 2 \mathrm{H}), 1.38(\mathrm{~s}, 9 \mathrm{H})$.

${ }^{13} \mathrm{C}$ NMR $\left(75 \mathrm{MHz}, \mathrm{CDCl}_{3}\right): \delta=172.9\left(\mathrm{C}_{\mathrm{q}}\right), 164.8\left(\mathrm{C}_{\mathrm{q}},{ }^{1} J_{\mathrm{C}-\mathrm{F}}=245.2 \mathrm{~Hz}\right), 158.0\left(\mathrm{C}_{\mathrm{q}},{ }^{3} J_{\mathrm{C}-\mathrm{F}}=12.4\right.$ $\mathrm{Hz}), 130.8\left(\mathrm{CH},{ }^{3} J_{\mathrm{C}-\mathrm{F}}=10.5 \mathrm{~Hz}\right), 117.6\left(\mathrm{C}_{\mathrm{q}},{ }^{4} J_{\mathrm{C}-\mathrm{F}}=2.8 \mathrm{~Hz}\right), 106.5\left(\mathrm{CH},{ }^{2} J_{\mathrm{C}-\mathrm{F}}=21.4 \mathrm{~Hz}\right), 105.4(\mathrm{CH}$, $\left.{ }^{2} J_{\mathrm{C}-\mathrm{F}}=24.1 \mathrm{~Hz}\right), 52.2\left(\mathrm{C}_{\mathrm{q}}\right), 41.6\left(\mathrm{CH}_{2}\right), 28.4\left(\mathrm{CH}_{3}\right)$.

IR (ATR): 1643, 1604, 1517, 1264, 906, 729, $650 \mathrm{~cm}^{-1}$.

MS (EI) $m / z$ (relative intensity): $225(30)[\mathrm{M}]^{+}, 152(40), 126$ (60).

HR-MS (EI) $m / z$ calcd for $\mathrm{C}_{12} \mathrm{H}_{16} \mathrm{FNO}_{2}{ }^{+}[\mathrm{M}]^{+}:$:225.1165, found: 225.1161 .<smiles>CC(C)(C)NC(=O)Cc1cc(Br)ccc1O</smiles>

\section{2-(5-Bromo-2-hydroxyphenyl)-N-(tert-butyl)acetamide (135ta):}

The general procedure $\mathbf{C}$ was followed using 2-(3-bromophenyl)- $N$-(tert-butyl)acetamide (132t) (135 $\mathrm{mg}, 0.50 \mathrm{mmol}), \mathrm{PhI}(\mathrm{TFA})_{2}(430 \mathrm{mg}, 1.00 \mathrm{mmol})$ and $\left[\mathrm{RuCl}_{2}(p \text {-cymene })\right]_{2}(15.3 \mathrm{mg}, 5.0 \mathrm{~mol} \%)$ in 
DCE $(2.0 \mathrm{~mL})$. Isolation by column chromatography ( $n$-hexane/EtOAc: $5 / 1)$ yielded 135ta $(108.7$ $\mathrm{mg}, 76 \%)$ as a white solid.

M.p. $=132-133{ }^{\circ} \mathrm{C}$.

${ }^{1}$ H NMR $\left(300 \mathrm{MHz}, \mathrm{CDCl}_{3}\right): \delta=10.40\left(\mathrm{~s}_{\mathrm{br}}, 1 \mathrm{H}\right), 7.25-7.20(\mathrm{~m}, 1 \mathrm{H}), 7.08(\mathrm{~d}, J=2.4 \mathrm{~Hz}, 1 \mathrm{H}), 6.83(\mathrm{~d}$, $J=8.6 \mathrm{~Hz}, 1 \mathrm{H}), 5.77(\mathrm{~s} \mathrm{br}, 1 \mathrm{H}), 3.41(\mathrm{~s}, 2 \mathrm{H}), 1.33(\mathrm{~s}, 9 \mathrm{H})$.

${ }^{13} \mathbf{C ~ N M R}\left(125 \mathrm{MHz}, \mathrm{CDCl}_{3}\right): \delta=172.3\left(\mathrm{C}_{\mathrm{q}}\right), 155.9\left(\mathrm{C}_{\mathrm{q}}\right), 132.6(\mathrm{CH}), 131.7(\mathrm{CH}), 123.8\left(\mathrm{C}_{\mathrm{q}}\right), 120.0$ $(\mathrm{CH}), 111.5\left(\mathrm{C}_{\mathrm{q}}\right), 52.5\left(\mathrm{C}_{\mathrm{q}}\right), 42.2\left(\mathrm{CH}_{2}\right), 28.6\left(\mathrm{CH}_{3}\right)$.

IR (ATR): 1634, 1566, 1412, 1268, 1151, 817, $628 \mathrm{~cm}^{-1}$.

MS (EI) $m / z$ (relative intensity): $285(15)\left[\mathrm{M},{ }^{79} \mathrm{Br}\right]^{+}, 211(45), 186$ (40).

HR-MS (EI) $m / z$ calcd for $\mathrm{C}_{12} \mathrm{H}_{16}{ }^{79} \mathrm{BrNO}_{2}{ }^{+}[\mathrm{M}]^{+}$: 285.0364, found: 285.0363.<smiles>CC(=O)Oc1ccc(CC(=O)NC(C)(C)C)c(O)c1</smiles>

\section{4-(2-(tert-Butylamino)-2-oxoethyl)-3-hydroxyphenyl acetate (135ra):}

The general procedure $\mathbf{C}$ was followed using 4-(2-(tert-butylamino)-2-oxoethyl)phenyl acetate (132r) (124.5 mg, $0.50 \mathrm{mmol}), \mathrm{PhI}(\mathrm{TFA})_{2}(430 \mathrm{mg}, 1.00 \mathrm{mmol})$ and $\left[\mathrm{RuCl}_{2}(p \text {-cymene })\right]_{2}(15.3 \mathrm{mg}, 5.0$ mol \%) in DCE $(2.0 \mathrm{~mL})$. Isolation by column chromatography ( $n$-hexane/EtOAc: $5 / 1)$ yielded 135ra $(63.6 \mathrm{mg}, 48 \%)$ as a colorless oil.

${ }^{1}$ H NMR $\left(300 \mathrm{MHz}, \mathrm{CDCl}_{3}\right): \delta=10.57\left(\mathrm{~s}_{\mathrm{br}}, 1 \mathrm{H}\right), 6.92(\mathrm{~d}, J=8.2 \mathrm{~Hz}, 1 \mathrm{H}), 6.66(\mathrm{~d}, J=2.4 \mathrm{~Hz}, 1 \mathrm{H})$, $6.54(\mathrm{dd}, J=8.2,2.4 \mathrm{~Hz}, 1 \mathrm{H}), 5.71(\mathrm{~s}, 1 \mathrm{H}), 3.42(\mathrm{~s}, 2 \mathrm{H}), 2.25(\mathrm{~s}, 3 \mathrm{H}), 1.32(\mathrm{~s}, 9 \mathrm{H})$.

${ }^{13} \mathrm{C}$ NMR $\left(125 \mathrm{MHz}, \mathrm{CDCl}_{3}\right): \delta=172.7\left(\mathrm{C}_{\mathrm{q}}\right), 169.3\left(\mathrm{C}_{\mathrm{q}}\right), 157.6\left(\mathrm{C}_{\mathrm{q}}\right), 151.0\left(\mathrm{C}_{\mathrm{q}}\right), 130.5(\mathrm{CH}), 121.9$ $\left(\mathrm{C}_{\mathrm{q}}\right), 112.9(\mathrm{CH}), 111.6(\mathrm{CH}), 52.4\left(\mathrm{C}_{\mathrm{q}}\right), 42.2\left(\mathrm{CH}_{2}\right), 28.6\left(\mathrm{CH}_{3}\right), 21.2\left(\mathrm{CH}_{3}\right)$.

IR (ATR): 1640, 1552, 1392, 1205, 1145, $731 \mathrm{~cm}^{-1}$.

MS (EI) $m / z$ (relative intensity): $265(20)[\mathrm{M}]^{+}, 193(30), 165(60)$.

HR-MS (EI) $m / z$ calcd for $\mathrm{C}_{14} \mathrm{H}_{19} \mathrm{NO}_{4}{ }^{+}[\mathrm{M}]^{+}:$265.1314, found: 265.1312. 
<smiles>CC(C)(C)NC(=O)Cc1ccc([N+](=O)[O-])cc1O</smiles>

\section{$N$-(tert-butyl)-2-(2-hydroxy-4-nitrophenyl)acetamide (135wa):}

The general procedure $\mathbf{C}$ was followed using $N$-(tert-butyl)-2-(4-nitrophenyl)acetamide (132w) (118 $\mathrm{mg}, 0.50 \mathrm{mmol}), \mathrm{PhI}(\mathrm{TFA})_{2}(430 \mathrm{mg}, 1.00 \mathrm{mmol})$ and $\left[\mathrm{RuCl}_{2}(p \text {-cymene })\right]_{2}(15.3 \mathrm{mg}, 5.0 \mathrm{~mol} \%)$ in DCE $(2.0 \mathrm{~mL})$. Isolation by column chromatography ( $n$-hexane/EtOAc: $5 / 1)$ yielded $\mathbf{1 3 5 w a}(81.9 \mathrm{mg}$, $65 \%)$ as a white solid.

M.p. $=128-129^{\circ} \mathrm{C}$.

${ }^{1}$ H NMR $\left(300 \mathrm{MHz}, \mathrm{CDCl}_{3}\right): \delta=11.06\left(\mathrm{~s}_{\mathrm{br}}, 1 \mathrm{H}\right), 7.81(\mathrm{~d}, J=2.3 \mathrm{~Hz}, 1 \mathrm{H}), 7.69(\mathrm{dd}, J=8.3,2.3 \mathrm{~Hz}$, $1 \mathrm{H}), 7.14(\mathrm{~d}, J=8.3 \mathrm{~Hz}, 1 \mathrm{H}), 5.81(\mathrm{~s} \mathrm{br}, 1 \mathrm{H}), 3.60(\mathrm{~s}, 2 \mathrm{H}), 1.39(\mathrm{~s}, 9 \mathrm{H})$.

${ }^{13}$ C NMR $\left(75 \mathrm{MHz}, \mathrm{CDCl}_{3}\right): \delta=170.1\left(\mathrm{C}_{\mathrm{q}}\right), 157.7\left(\mathrm{C}_{\mathrm{q}}\right), 148.7\left(\mathrm{C}_{\mathrm{q}}\right), 130.0(\mathrm{CH}), 127.7\left(\mathrm{C}_{\mathrm{q}}\right), 114.6$ $(\mathrm{CH}), 113.2(\mathrm{CH}), 51.7\left(\mathrm{C}_{\mathrm{q}}\right), 42.1\left(\mathrm{CH}_{2}\right), 27.8\left(\mathrm{CH}_{3}\right)$.

IR (ATR): 1643, 1520, 1426, 1318, 899, $730 \mathrm{~cm}^{-1}$.

MS (EI) $m / z$ (relative intensity): $252(20)[\mathrm{M}]^{+}, 179(50), 153(90)$.

HR-MS (EI) $m / z$ calcd for $\mathrm{C}_{12} \mathrm{H}_{16} \mathrm{~N}_{2} \mathrm{O}_{4}{ }^{+}[\mathrm{M}]^{+}:$: 252.1110, found: 252.1109 .<smiles>CCCCCCCCCCC(=O)NCc1c(O)cccc1Br</smiles>

\section{2-(2-Bromo-6-hydroxyphenyl)-n-butylacetamide (135'aa) :}

The general procedure $\mathbf{C}$ was followed using 2-(2-bromophenyl)-n-butylacetamide (132'a) (134.5 $\mathrm{mg}, 0.50 \mathrm{mmol}), \mathrm{PhI}(\mathrm{TFA})_{2}(430 \mathrm{mg}, 1.00 \mathrm{mmol})$ and $\left[\mathrm{RuCl}_{2}(p \text {-cymene })\right]_{2}(15.3 \mathrm{mg}, 5.0 \mathrm{~mol} \%)$ in DCE $(2.0 \mathrm{~mL})$. Isolation by column chromatography ( $n$-hexane/EtOAc: $5 / 1)$ yielded 135'aa (82.6 mg, $58 \%)$ as a white solid.

M.p. $=133-134{ }^{\circ} \mathrm{C}$.

${ }^{1}$ H NMR $\left(300 \mathrm{MHz}, \mathrm{CDCl}_{3}\right): \delta=9.99\left(\mathrm{~s}_{\mathrm{br}}, 1 \mathrm{H}\right), 7.13(\mathrm{dd}, J=7.8,1.4 \mathrm{~Hz}, 1 \mathrm{H}), 7.04(\mathrm{dd}, J=8.0,7.8 \mathrm{~Hz}$, $1 \mathrm{H}), 6.96(\mathrm{dd}, J=8.0,1.4 \mathrm{~Hz}, 1 \mathrm{H}), 5.99(\mathrm{~s} b \mathrm{H}, 1 \mathrm{H}), 3.83(\mathrm{~s}, 2 \mathrm{H}), 3.29(\mathrm{~m}, 2 \mathrm{H}), 1.59-1.47(\mathrm{~m}, 2 \mathrm{H}), 1.42-$ $1.30(\mathrm{~m}, 2 \mathrm{H}), 0.93(\mathrm{t}, J=9.1,3 \mathrm{H})$. 
${ }^{13}$ C NMR $\left(75 \mathrm{MHz}, \mathrm{CDCl}_{3}\right): \delta=172.5\left(\mathrm{C}_{\mathrm{q}}\right), 157.3\left(\mathrm{C}_{\mathrm{q}}\right), 129.6(\mathrm{CH}), 124.3(\mathrm{CH}), 124.2\left(\mathrm{C}_{\mathrm{q}}\right), 122.1$ $\left(\mathrm{C}_{\mathrm{q}}\right), 117.7(\mathrm{CH}), 39.9\left(\mathrm{CH}_{2}\right), 39.7\left(\mathrm{CH}_{2}\right), 31.2\left(\mathrm{CH}_{2}\right), 19.9\left(\mathrm{CH}_{2}\right), 13.6\left(\mathrm{CH}_{3}\right)$.

IR (ATR): 1643, 1538, 1484, 1361, 1063, 963, $866 \mathrm{~cm}^{-1}$.

MS (EI) $m / z$ (relative intensity): $285(40)\left[\mathrm{M},{ }^{79} \mathrm{Br}\right]^{+}, 206$ (90), $186(70)$.

HR-MS (EI) $\mathrm{m} / z$ calcd for $\mathrm{C}_{12} \mathrm{H}_{16}{ }^{79} \mathrm{BrNO}_{2}{ }^{+}[\mathrm{M}]^{+}:$285.0364, found: 285.0360.<smiles>COC(=O)Cc1ccccc1O</smiles>

\section{Methyl 2-(2-hydroxyphenyl)acetate (135aa):}

The general procedure $\mathbf{C}$ was followed using methyl 2-phenylacetate (134a) (75 mg, $0.50 \mathrm{mmol}$ ), $\mathrm{PhI}(\mathrm{TFA})_{2}(430 \mathrm{mg}, 1.00 \mathrm{mmol})$ and $\left[\mathrm{RuCl}_{2}(p \text {-cymene })\right]_{2}(15.3 \mathrm{mg}, 5.0 \mathrm{~mol} \%)$ in DCE $(2.0 \mathrm{~mL})$. Isolation by column chromatography ( $n$-hexane/EtOAc: $5 / 1$ ) yielded 135aa $(41.5 \mathrm{mg}, 50 \%$ ) as a colorless liquid.

${ }^{1}$ H NMR $\left(400 \mathrm{MHz}, \mathrm{CDCl}_{3}\right): \delta=7.30\left(\mathrm{~s}_{\mathrm{br}}, 1 \mathrm{H}\right), 7.21-7.15(\mathrm{~m}, 1 \mathrm{H}), 7.10-7.06(\mathrm{~m}, 1 \mathrm{H}), 6.93(\mathrm{dd}, J=$ 8.1, 0.9 Hz, 1H), 6.87 (td, $J=7.4,1.2 \mathrm{~Hz}, 1 \mathrm{H}), 3.74$ (s, 3H), 3.67 (s, 2H).

${ }^{13}$ C NMR (100 MHz, $\left.\mathrm{CDCl}_{3}\right): \delta=174.3\left(\mathrm{C}_{\mathrm{q}}\right), 155.2\left(\mathrm{C}_{\mathrm{q}}\right), 131.0(\mathrm{CH}), 129.3(\mathrm{CH}), 121.0(\mathrm{CH}), 120.5$ $\left(\mathrm{C}_{\mathrm{q}}\right), 117.7(\mathrm{CH}), 52.8\left(\mathrm{CH}_{3}\right), 37.8\left(\mathrm{CH}_{2}\right)$.

IR (ATR): 1642, 1535, 1412, 1228, 1058, 914, $730 \mathrm{~cm}^{-1}$.

MS (EI) $m / z$ (relative intensity): $166(20)[\mathrm{M}]^{+}, 134(90), 106(80)$.

HR-MS (EI) $\mathrm{m} / z$ calcd for $\mathrm{C}_{9} \mathrm{H}_{10} \mathrm{O}_{3}{ }^{+}[\mathrm{M}]^{+}:$166.0630, found: 166.0627 .<smiles>CCOC(=O)Cc1ccccc1O</smiles>

\section{Ethyl 2-(2-hydroxyphenyl)acetate (135ba):}

The general procedure $\mathbf{C}$ was followed using ethyl 2-phenylacetate (134b) $(82 \mathrm{mg}, 0.50 \mathrm{mmol})$, $\mathrm{PhI}(\mathrm{TFA})_{2}(430 \mathrm{mg}, 1.00 \mathrm{mmol})$ and $\left[\mathrm{RuCl}_{2}(p \text {-cymene })\right]_{2}(15.3 \mathrm{mg}, 5.0 \mathrm{~mol} \%)$ in DCE $(2.0 \mathrm{~mL})$. Isolation by column chromatography ( $n$-hexane/EtOAc: $5 / 1)$ yielded 135ba $(45 \mathrm{mg}, 50 \%)$ as a colorless liquid. 
${ }^{1}$ H NMR $\left(300 \mathrm{MHz}, \mathrm{CDCl}_{3}\right): \delta=7.63\left(\mathrm{~s}_{\mathrm{br}}, 1 \mathrm{H}\right), 7.26-7.19(\mathrm{~m}, 1 \mathrm{H}), 7.12(\mathrm{~d}, J=6.3 \mathrm{~Hz}, 1 \mathrm{H}), 7.00-6.87$ $(\mathrm{m}, 2 \mathrm{H}), 4.23(\mathrm{q}, J=7.2 \mathrm{~Hz}, 2 \mathrm{H}), 3.70(\mathrm{~s}, 2 \mathrm{H}), 1.31(\mathrm{t}, J=7.2 \mathrm{~Hz}, 3 \mathrm{H})$.

${ }^{13}$ C NMR (75 MHz, $\left.\mathrm{CDCl}_{3}\right): \delta=166.7\left(\mathrm{C}_{\mathrm{q}}\right), 144.4\left(\mathrm{C}_{\mathrm{q}}\right), 131.0(\mathrm{CH}), 129.2(\mathrm{CH}), 120.9(\mathrm{CH}), 117.9$ $\left(\mathrm{C}_{\mathrm{q}}\right), 100.0(\mathrm{CH}), 62.0\left(\mathrm{CH}_{2}\right), 38.2\left(\mathrm{CH}_{2}\right), 14.0\left(\mathrm{CH}_{3}\right)$.

IR (ATR): 1703, 1642, 1422, 1359, 1110, 964, $732 \mathrm{~cm}^{-1}$.

MS (EI) $m / z$ (relative intensity): 180 (20) [M] $]^{+}, 134$ (90), 106 (85).

HR-MS (EI) $m / z$ calcd for $\mathrm{C}_{10} \mathrm{H}_{12} \mathrm{O}_{3}{ }^{+}[\mathrm{M}]^{+}:$180.0786, found: 180.0789 . 


\subsubsection{Cobalt-Catalyzed C-H Arylation}

\section{Analytical Data}<smiles>O=C(Nc1cccc2cccnc12)c1ccccc1-c1ccccc1</smiles>

\section{$N$-(Quinolin-8-yl)-[1,1'-biphenyl]-2-carboxamide (137ba):}

The general procedure $\mathbf{D}$ was followed using $N$-(quinolin-8-yl)benzamide $\mathbf{9 b}(62 \mathrm{mg}, 0.25 \mathrm{mmol}$ ) and trimethoxy(phenyl)silane 136a $(99 \mathrm{mg}, 0.50 \mathrm{mmol}$ ). Isolation by column chromatography ( $n$-hexane/acetone: 10/1) yielded $137 \mathrm{ba}(56.7 \mathrm{mg}, 70 \%$ ) as a white solid.

M. p. $=125-126^{\circ} \mathrm{C}$.

${ }^{1}$ H NMR (300 MHz, $\left.\mathrm{CDCl}_{3}\right): \delta=9.77\left(\mathrm{~s}_{\mathrm{br}}, 1 \mathrm{H}\right), 8.80(\mathrm{dd}, J=7.4,1.5 \mathrm{~Hz}, 1 \mathrm{H}), 8.51(\mathrm{dd}, J=4.2,1.7 \mathrm{~Hz}$, $1 \mathrm{H}), 8.05(\mathrm{dd}, J=8.3,1.7 \mathrm{~Hz}, 1 \mathrm{H}), 7.90(\mathrm{dd}, J=3.1,1.9 \mathrm{~Hz}, 1 \mathrm{H}), 7.60-7.39(\mathrm{~m}, 7 \mathrm{H}), 7.36-7.24(\mathrm{~m}$, $3 \mathrm{H}), 7.18-7.11(\mathrm{~m}, 1 \mathrm{H})$.

${ }^{13}$ C NMR (125 MHz, $\left.\mathrm{CDCl}_{3}\right): \delta=167.6\left(\mathrm{C}_{\mathrm{q}}\right), 147.6(\mathrm{CH}), 140.2\left(\mathrm{C}_{\mathrm{q}}\right), 139.9\left(\mathrm{C}_{\mathrm{q}}\right), 138.3\left(\mathrm{C}_{\mathrm{q}}\right), 136.0$ $\left(\mathrm{C}_{\mathrm{q}}\right), 135.9(\mathrm{CH}), 134.5\left(\mathrm{C}_{\mathrm{q}}\right), 130.6(\mathrm{CH}), 130.4(\mathrm{CH}), 129.1(\mathrm{CH}), 128.9(\mathrm{CH}), 128.3\left(\mathrm{C}_{\mathrm{q}}\right), 127.6(\mathrm{CH})$, $127.5(\mathrm{CH}), 127.5(\mathrm{CH}), 127.2(\mathrm{CH}), 121.4(\mathrm{CH}), 121.3(\mathrm{CH}), 116.2(\mathrm{CH})$.

IR (ATR): 1669, 1523, 1483, 1326, 826, $765 \mathrm{~cm}^{-1}$.

MS (EI) $m / z$ (relative intensity): 324 (40) $[\mathrm{M}]^{+}, 181$ (100), 152 (55).

HR-MS (EI) $m / z$ calcd for $\mathrm{C}_{22} \mathrm{H}_{16} \mathrm{~N}_{2} \mathrm{O}^{+}[\mathrm{M}]^{+}: 380.1263$, found: 324.1257 . 
<smiles>Cc1cccc(-c2ccccc2)c1C(=O)Nc1cccc2cccnc12</smiles>

\section{3-Methyl- $N$-(quinolin-8-yl)-[1,1'-biphenyl]-2-carboxamide (137aa):}

The general procedure $\mathbf{D}$ was followed using 2-methyl- $N$-(quinolin-8-yl)benzamide 9a $(65.5 \mathrm{mg}$, $0.25 \mathrm{mmol}$ ) and trimethoxy(phenyl)silane 136a (99 $\mathrm{mg}, 0.50 \mathrm{mmol})$. Isolation by column chromatography ( $n$-hexane/acetone: 10/1) yielded 137aa $(60.8 \mathrm{mg}, 72 \%)$ as a pale yellow solid.

M. p. $=120-121^{\circ} \mathrm{C}$.

${ }^{1}$ H NMR $\left(400 \mathrm{MHz}, \mathrm{CDCl}_{3}\right): \delta=9.61\left(\mathrm{~s}_{\mathrm{br}}, 1 \mathrm{H}\right), 8.75(\mathrm{dd}, J=7.4,1.6 \mathrm{~Hz}, 1 \mathrm{H}), 8.59(\mathrm{dd}, J=4.2,1.7$ $\mathrm{Hz}, 1 \mathrm{H}), 8.06(\mathrm{dd}, J=8.3,1.7 \mathrm{~Hz}, 1 \mathrm{H}), 7.51(\mathrm{dd}, J=3.4,1.3 \mathrm{~Hz}, 1 \mathrm{H}), 7.50-7.49(\mathrm{~m}, 1 \mathrm{H}), 7.48(\mathrm{~d}, J$ $=7.4 \mathrm{~Hz}, 1 \mathrm{H}), 7.45-7.41(\mathrm{~m}, 1 \mathrm{H}), 7.40-7.37(\mathrm{~m}, 1 \mathrm{H}), 7.34(\mathrm{dd}, J=8.3,4.2 \mathrm{~Hz}, 1 \mathrm{H}), 7.30(\mathrm{dd}, J=$ 1.6, 0.6 Hz, 1H), 7.28 (ddd, $J=2.0,1.3,0.7 \mathrm{~Hz}, 1 \mathrm{H}), 7.22-7.17(\mathrm{~m}, 2 \mathrm{H}), 7.10-7.05(\mathrm{~m}, 1 \mathrm{H}), 2.52$ (s, $3 \mathrm{H})$.

${ }^{13}$ C NMR $\left(100 \mathrm{MHz}, \mathrm{CDCl}_{3}\right): \delta=168.3\left(\mathrm{C}_{\mathrm{q}}\right), 148.0(\mathrm{CH}), 140.4\left(\mathrm{C}_{\mathrm{q}}\right), 139.7\left(\mathrm{C}_{\mathrm{q}}\right), 138.4\left(\mathrm{C}_{\mathrm{q}}\right), 136.9$ $\left(\mathrm{C}_{\mathrm{q}}\right), 136.1(\mathrm{CH}), 135.8\left(\mathrm{C}_{\mathrm{q}}\right), 134.4\left(\mathrm{C}_{\mathrm{q}}\right), 129.5(\mathrm{CH}), 129.2(\mathrm{CH}), 128.6(\mathrm{CH}), 128.1(\mathrm{CH}), 127.8$ $\left(\mathrm{C}_{\mathrm{q}}\right), 127.6(\mathrm{CH}), 127.2(\mathrm{CH}), 127.2(\mathrm{CH}), 121.6(\mathrm{CH}), 121.4(\mathrm{CH}), 116.4(\mathrm{CH}), 19.8\left(\mathrm{CH}_{3}\right)$.

IR (ATR): 1671, 1483, 1424, 1328, 791, $698 \mathrm{~cm}^{-1}$.

MS (EI) $m / z$ (relative intensity): $338(25)[\mathrm{M}]^{+}, 195(30)$.

HR-MS (ESI) $m / z$ calcd for $\mathrm{C}_{23} \mathrm{H}_{18} \mathrm{~N}_{2} \mathrm{O}^{+}[\mathrm{M}]^{+}: 338.1419$, found: 338.1419 .<smiles>COc1ccc(-c2ccccc2)c(C(=O)Nc2cccc3cccnc23)c1</smiles>

\section{4-Methyl- $N$-(quinolin-8-yl)-[1,1'-biphenyl]-2-carboxamide (137ca):}

The general procedure D was followed using 3-methyl- $N$-(quinolin-8-yl)benzamide 9c (65.5 mg, $0.25 \mathrm{mmol}$ ) and trimethoxy(phenyl)silane 136a (98 $\mathrm{mg}, 0.50 \mathrm{mmol}$ ). Isolation by column chromatography ( $n$-hexane/acetone: $10 / 1)$ yielded $137 \mathrm{ca}(51.5 \mathrm{mg}, 61 \%)$ as a white solid.

M. p. $=136-137^{\circ} \mathrm{C}$. 
${ }^{1}$ H NMR $\left(400 \mathrm{MHz}, \mathrm{CDCl}_{3}\right): \delta=9.72\left(\mathrm{~s}_{\mathrm{br}}, 1 \mathrm{H}\right), 8.79(\mathrm{dd}, J=7.6,1.3 \mathrm{~Hz}, 1 \mathrm{H}), 8.49(\mathrm{dd}, J=4.2,1.7$ $\mathrm{Hz}, 1 \mathrm{H}), 8.05(\mathrm{dd}, J=8.3,1.7 \mathrm{~Hz}, 1 \mathrm{H}), 7.71(\mathrm{~d}, J=0.8 \mathrm{~Hz}, 1 \mathrm{H}), 7.49(\mathrm{dd}, J=8.4,7.4 \mathrm{~Hz}, 3 \mathrm{H}), 7.43$ $(\mathrm{dd}, J=8.3,1.4 \mathrm{~Hz}, 1 \mathrm{H}), 7.36(\mathrm{~d}, J=0.9 \mathrm{~Hz}, 2 \mathrm{H}), 7.32(\mathrm{dd}, J=8.3,4.2 \mathrm{~Hz}, 1 \mathrm{H}), 7.27-7.23(\mathrm{~m}, 2 \mathrm{H})$, 7.12 (ddd, $J=8.7,2.5,1.3 \mathrm{~Hz}, 1 \mathrm{H}), 2.46(\mathrm{~s}, 3 \mathrm{H})$.

${ }^{13}$ C NMR $\left(100 \mathrm{MHz}, \mathrm{CDCl}_{3}\right): \delta=168.0\left(\mathrm{C}_{\mathrm{q}}\right), 147.7(\mathrm{CH}), 134.0\left(\mathrm{C}_{\mathrm{q}}\right), 138.4\left(\mathrm{C}_{\mathrm{q}}\right), 137.5\left(\mathrm{C}_{\mathrm{q}}\right), 137.4$ $\left(\mathrm{C}_{\mathrm{q}}\right), 136.0\left(\mathrm{C}_{\mathrm{q}}\right), 135.9(\mathrm{CH}), 134.6\left(\mathrm{C}_{\mathrm{q}}\right), 131.2(\mathrm{CH}), 130.6(\mathrm{CH}), 129.8(\mathrm{CH}), 129.0(\mathrm{CH}), 128.3$ $(\mathrm{CH}), 127.7\left(\mathrm{C}_{\mathrm{q}}\right), 127.4(\mathrm{CH}), 127.3(\mathrm{CH}), 121.4(\mathrm{CH}), 121.3(\mathrm{CH}), 116.2(\mathrm{CH}), 21.0\left(\mathrm{CH}_{3}\right)$.

IR (ATR): 1659, 1519, 1482, 1279, 766, $665 \mathrm{~cm}^{-1}$.

MS (EI) $m / z$ (relative intensity): $338(35)[\mathrm{M}]^{+}, 195$ (100), 152 (30).

HR-MS (EI) $m / z$ calcd for $\mathrm{C}_{23} \mathrm{H}_{18} \mathrm{~N}_{2} \mathrm{O}^{+}[\mathrm{M}]^{+}: 338.1419$, found: 338.1420 .<smiles>Cc1ccc(C(=O)Nc2cccc3cccnc23)c(-c2ccccc2)c1</smiles>

\section{5-Methyl- $N$-(quinolin-8-yl)-[1,1'-biphenyl]-2-carboxamide (137da):}

The general procedure D was followed using 4-methyl- $N$-(quinolin-8-yl)benzamide 9d (65.5 mg, $0.25 \mathrm{mmol}$ ) and trimethoxy(phenyl)silane 136a (99 $\mathrm{mg}, 0.50 \mathrm{mmol}$ ). Isolation by column chromatography ( $n$-hexane/acetone: 10/1) yielded 137da (49 mg, 58\%) as a white solid.

M. p. $=118-119^{\circ} \mathrm{C}$.

${ }^{1}$ H NMR $\left(300 \mathrm{MHz}, \mathrm{CDCl}_{3}\right): \delta=9.74\left(\mathrm{~S}_{\mathrm{br}}, 1 \mathrm{H}\right), 8.79(\mathrm{dd}, J=7.5,1.4 \mathrm{~Hz}, 1 \mathrm{H}), 8.49(\mathrm{dd}, J=4.2,1.7 \mathrm{~Hz}$, $1 \mathrm{H}), 8.04(\mathrm{dd}, J=8.3,1.7 \mathrm{~Hz}, 1 \mathrm{H}), 7.82(\mathrm{~d}, J=7.5 \mathrm{~Hz}, 1 \mathrm{H}), 7.50(\mathrm{dd}, J=3.5,2.1 \mathrm{~Hz}, 1 \mathrm{H}), 7.49-7.46$ (m, 2H), 7.44-7.40 (m, 1H), 7.34-7.29 (m, 2H), 7.29-7.25 (m, 3H), 7.17-7.11 (m, 1H), $2.45(\mathrm{~s}, 3 \mathrm{H})$. ${ }^{13}$ C NMR (125 MHz, $\left.\mathrm{CDCl}_{3}\right): \delta=167.6\left(\mathrm{C}_{\mathrm{q}}\right), 147.5(\mathrm{CH}), 140.6\left(\mathrm{C}_{\mathrm{q}}\right), 140.2\left(\mathrm{C}_{\mathrm{q}}\right), 140.1\left(\mathrm{C}_{\mathrm{q}}\right), 138.3$ $\left(\mathrm{C}_{\mathrm{q}}\right), 135.8(\mathrm{CH}), 134.6\left(\mathrm{C}_{\mathrm{q}}\right), 133.3\left(\mathrm{C}_{\mathrm{q}}\right), 131.3(\mathrm{CH}), 129.3(\mathrm{CH}), 128.9(\mathrm{CH}), 128.2(\mathrm{CH}), 128.2$ $(\mathrm{CH}), 127.6\left(\mathrm{C}_{\mathrm{q}}\right), 127.4(\mathrm{CH}), 127.2(\mathrm{CH}), 121.2(\mathrm{CH}), 121.2(\mathrm{CH}), 116.1(\mathrm{CH}), 21.5\left(\mathrm{CH}_{3}\right)$.

IR (ATR): 1661, 1520, 1482, 1263, 853, $765 \mathrm{~cm}^{-1}$.

MS (EI) $m / z$ (relative intensity): 338 (30) [M] $]^{+}, 195$ (90), 165 (30).

HR-MS (EI) $m / z$, calcd for $\mathrm{C}_{23} \mathrm{H}_{18} \mathrm{~N}_{2} \mathrm{O}^{+}[\mathrm{M}]^{+}: 338.1419$, found: 338.1423 . 
<smiles>Cc1cccc(C)c1-c1cccc(-c2ccccc2)c1C(=O)Nc1cccc2cccnc12</smiles>

\section{2,6-Dimethyl- $N$-(quinolin-8-yl)-[1,1':3',1'-terphenyl]-2'-carboxamide (137eb):}

The general procedure $\mathbf{D}$ was followed using $N$-(quinolin-8-yl)-[1,1'-biphenyl]-2-carboxamide 9e (81 $\mathrm{mg}, 0.25 \mathrm{mmol})$ and (2,6-dimethylphenyl)trimethoxysilane $\mathbf{1 3 6} \mathbf{b}(113 \mathrm{mg}, 0.50 \mathrm{mmol})$. Isolation by column chromatography ( $n$-hexane/acetone: 10/1) yielded $137 \mathbf{e b}(70 \mathrm{mg}, 68 \%)$ as a white solid.

M. p. $=210-211^{\circ} \mathrm{C}$

${ }^{1}$ H NMR $\left(300 \mathrm{MHz}, \mathrm{CDCl}_{3}\right): \delta=9.48\left(\mathrm{~s}_{\mathrm{br}}, 1 \mathrm{H}\right), 8.59(\mathrm{dd}, J=4.2,1.7 \mathrm{~Hz}, 1 \mathrm{H}), 8.39(\mathrm{dd}, J=6.1,2.9 \mathrm{~Hz}$, 1H), 8.03-7.99 (m, 1H), 7.59-7.54 (m, 3H), 7.50-7.47 (m, 1H), 7.37-7.28 (m, 4H), 7.23-7.17 (m, 3H), 7.15-7.08 (m, 1H), $6.95(\mathrm{~d}, J=1.7 \mathrm{~Hz}, 2 \mathrm{H}), 2.20(\mathrm{~s}, 6 \mathrm{H})$.

${ }^{13} \mathrm{C}$ NMR $\left(125 \mathrm{MHz}, \mathrm{CDCl}_{3}\right): \delta=166.8\left(\mathrm{C}_{\mathrm{q}}\right), 147.5(\mathrm{CH}), 140.4\left(\mathrm{C}_{\mathrm{q}}\right), 140.3\left(\mathrm{C}_{\mathrm{q}}\right), 139.5\left(\mathrm{C}_{\mathrm{q}}\right), 139.4$ $\left(\mathrm{C}_{\mathrm{q}}\right), 138.1\left(\mathrm{C}_{\mathrm{q}}\right), 136.3\left(\mathrm{C}_{\mathrm{q}}\right), 136.3\left(\mathrm{C}_{\mathrm{q}}\right), 135.8(\mathrm{CH}), 134.2\left(\mathrm{C}_{\mathrm{q}}\right), 129.4(\mathrm{CH}), 129.0(\mathrm{CH}), 128.8(\mathrm{CH})$, $128.7(\mathrm{CH}), 128.1(\mathrm{CH}), 127.5\left(\mathrm{C}_{\mathrm{q}}\right), 127.2(\mathrm{CH}), 127.2(\mathrm{CH}), 127.1(\mathrm{CH}), 127.0(\mathrm{CH}), 121.2(\mathrm{CH})$, $121.0(\mathrm{CH}), 116.1(\mathrm{CH}), 21.0\left(\mathrm{CH}_{3}\right)$.

IR (ATR): 1673, 1517, 1480, 1324, 824, $698 \mathrm{~cm}^{-1}$.

MS (EI) $m / z$ (relative intensity): 428 (30) [M] ${ }^{+}, 285$ (100), 241 (30), 144 (80).

HR-MS (EI) $m / z$ calcd for $\mathrm{C}_{30} \mathrm{H}_{24} \mathrm{~N}_{2} \mathrm{O}^{+}[\mathrm{M}]^{+}: 428.1889$, found: 428.1888 .<smiles>Cc1cccc(C)c1-c1cccc(F)c1C(=O)Nc1cccc2cccnc12</smiles>

\section{3-Fluoro-2',6'-dimethyl- $N$-(quinolin-8-yl)-[1,1'-biphenyl]-2-carboxamide (137fb):}

The general procedure $\mathbf{D}$ was followed using 2-fluoro- $N$-(quinolin-8-yl)benzamide 9f (66.5 mg, 0.25 mmol) and (2,6-dimethylphenyl)trimethoxysilane $\mathbf{1 3 6 b}(113 \mathrm{mg}, 0.50 \mathrm{mmol})$. Isolation by column chromatography ( $n$-hexane/acetone: $10 / 1)$ yielded $\mathbf{1 3 7 f b}(48 \mathrm{mg}, 52 \%)$ as a white solid. 
M. p. $=160-161^{\circ} \mathrm{C}$

${ }^{1}$ H NMR $\left(400 \mathrm{MHz}, \mathrm{CDCl}_{3}\right): \delta=9.87\left(\mathrm{~s}_{\mathrm{br}}, 1 \mathrm{H}\right), 8.72(\mathrm{dd}, J=4.2,1.7 \mathrm{~Hz}, 1 \mathrm{H}), 8.66(\mathrm{dd}, J=6.2,2.9 \mathrm{~Hz}$, 1H), 8.09 (dd, $J=8.4,1.7 \mathrm{~Hz}, 1 \mathrm{H}), 7.53-7.46(\mathrm{~m}, 1 \mathrm{H}), 7.44-7.37$ (m, 3H), 7.21 (ddd, $J=9.4,8.4,1.1$ Hz, 1H), 7.02-6.99 (m, 1H), 6.99-6.94 (m, 3H), 2.16 (s, 6H).

${ }^{13}$ C NMR $\left(100 \mathrm{MHz}, \mathrm{CDCl}_{3}\right): \delta=162.5\left(\mathrm{C}_{\mathrm{q}}\right), 159.9\left(\mathrm{C}_{\mathrm{q}},{ }^{1} J_{\mathrm{C}-\mathrm{F}}=250.1 \mathrm{~Hz}\right), 147.9(\mathrm{CH}), 141.6\left(\mathrm{C}_{\mathrm{q}}\right.$, $\left.{ }^{3} J_{\mathrm{C}-\mathrm{F}}=11.0 \mathrm{~Hz}\right), 138.3\left(\mathrm{C}_{\mathrm{q}}\right), 138.2\left(\mathrm{C}_{\mathrm{q}},{ }^{4} J_{\mathrm{C}-\mathrm{F}}=2.0 \mathrm{~Hz}\right), 136.1\left(\mathrm{C}_{\mathrm{q}}\right), 134.2\left(\mathrm{C}_{\mathrm{q}}\right), 131.2\left(\mathrm{CH},{ }^{3} J_{\mathrm{C}-\mathrm{F}}=9.0\right.$ $\mathrm{Hz}), 128.4(\mathrm{CH}), 127.8\left(\mathrm{C}_{\mathrm{q}}\right), 127.6(\mathrm{CH}), 127.3(\mathrm{CH}), 125.9\left(\mathrm{CH},{ }^{4} J_{\mathrm{C}-\mathrm{F}}=3.2 \mathrm{~Hz}\right), 125.4\left(\mathrm{C}_{\mathrm{q}},{ }^{2} J_{\mathrm{C}-\mathrm{F}}=\right.$ $16.3 \mathrm{~Hz}), 121.7(\mathrm{CH}), 121.5(\mathrm{CH}), 116.6(\mathrm{CH}), 114.9(\mathrm{CH}), 114.8\left(\mathrm{CH},{ }^{2} J_{\mathrm{C}-\mathrm{F}}=22.0 \mathrm{~Hz}\right), 20.7\left(\mathrm{CH}_{3}\right)$. ${ }^{19}$ F NMR $\left(376 \mathrm{MHz}, \mathrm{CDCl}_{3}\right): \delta=-114.6$.

IR (ATR): 1677, 1520, 1483, 1423, 905, $757 \mathrm{~cm}^{-1}$.

MS (EI) $m / z$ (relative intensity): 370 (20) [M] ${ }^{+}, 227$ (20), 183 (35), 144 (100).

HR-MS (EI) $m / z$ calcd for $\mathrm{C}_{24} \mathrm{H}_{19} \mathrm{FN}_{2} \mathrm{O}^{+}[\mathrm{M}]^{+}: 370.1481$, found: 370.1484 .<smiles>Cc1cccc(C)c1-c1cccc(C(F)(F)F)c1C(=O)Nc1cccc2cccnc12</smiles>

2',6'-Dimethyl- $N$-(quinolin-8-yl)-3-(trifluoromethyl)-[1,1'-biphenyl]-2-carboxamide (137gb):

The general procedure $\mathbf{D}$ was followed using $N$-(quinolin-8-yl)-2-(trifluoromethyl)benzamide $9 \mathrm{~g}$ (65.5 mg, $0.25 \mathrm{mmol}$ ) and (2,6-dimethylphenyl)trimethoxysilane $\mathbf{1 3 6 b}$ (113 $\mathrm{mg}, 0.50 \mathrm{mmol})$. Isolation by column chromatography ( $n$-hexane/acetone: 10/1) yielded 137gb (53 $\mathrm{mg}, 50 \%)$ as a white solid.

M. p. $=145-146^{\circ} \mathrm{C}$.

${ }^{1}$ H NMR (400 MHz, $\left.\mathrm{CDCl}_{3}\right): \delta=9.73\left(\mathrm{~s}_{\mathrm{br}}, 1 \mathrm{H}\right), 8.69(\mathrm{dd}, J=4.2,1.7 \mathrm{~Hz}, 1 \mathrm{H}), 8.56(\mathrm{dd}, J=6.6,2.4 \mathrm{~Hz}$, $1 \mathrm{H}), 8.08(\mathrm{dd}, J=8.3,1.7 \mathrm{~Hz}, 1 \mathrm{H}), 7.79(\mathrm{dd}, J=7.8,0.6 \mathrm{~Hz}, 1 \mathrm{H}), 7.64(\mathrm{td}, J=7.8,0.8 \mathrm{~Hz}, 1 \mathrm{H}), 7.44-$ $7.36(\mathrm{~m}, 4 \mathrm{H}), 6.95(\mathrm{dd}, J=9.0,5.5 \mathrm{~Hz}, 1 \mathrm{H}), 6.92-6.88(\mathrm{~m}, 2 \mathrm{H}), 2.15(\mathrm{~s}, 6 \mathrm{H})$.

${ }^{13}$ C NMR $\left(100 \mathrm{MHz}, \mathrm{CDCl}_{3}\right): \delta=164.5\left(\mathrm{C}_{\mathrm{q}}\right), 147.9(\mathrm{CH}), 140.4\left(\mathrm{C}_{\mathrm{q}}\right), 138.2\left(\mathrm{C}_{\mathrm{q}}\right), 137.7\left(\mathrm{C}_{\mathrm{q}}\right), 136.3$ $\left(\mathrm{C}_{\mathrm{q}}\right), 136.1(\mathrm{CH}), 135.3\left(\mathrm{C}_{\mathrm{q}},{ }^{3} J_{\mathrm{C}-\mathrm{F}}=2.0 \mathrm{~Hz}\right), 134.0\left(\mathrm{C}_{\mathrm{q}}\right), 133.7(\mathrm{CH}), 129.6(\mathrm{CH}), 128.1\left(\mathrm{C}_{\mathrm{q}},{ }^{2} J_{\mathrm{C}-\mathrm{F}}=\right.$ 
$31.0 \mathrm{~Hz}), 127.9(\mathrm{CH}), 127.7\left(\mathrm{C}_{\mathrm{q}}\right), 127.3(\mathrm{CH}), 127.3(\mathrm{CH}), 125.3\left(\mathrm{CH},{ }^{3} \mathrm{~J}=4.9 \mathrm{~Hz}\right), 123.8\left(\mathrm{C}_{\mathrm{q}},{ }^{1} \mathrm{~J}=\right.$ $272.0 \mathrm{~Hz}), 121.7(\mathrm{CH}), 121.5(\mathrm{CH}), 116.5(\mathrm{CH}), 20.8\left(\mathrm{CH}_{3}\right)$.

${ }^{19}$ F NMR $\left(376 \mathrm{~Hz}, \mathrm{CDCl}_{3}\right): \delta=-58.9$.

IR (ATR): 1680, 1526, 1322, 1127, 822, $789 \mathrm{~cm}^{-1}$.

MS (EI) $m / z$ (relative intensity): $420(20)[\mathrm{M}]^{+}, 276(80), 248$ (30).

HR-MS (EI) $m / z$ calcd for $\mathrm{C}_{25} \mathrm{H}_{19} \mathrm{~F}_{3} \mathrm{~N}_{2} \mathrm{O}^{+}[\mathrm{M}]^{+}$: 420.1443, found: 420.1446 .<smiles>Cc1cc(C)c(-c2cccc(C(F)(F)F)c2C(=O)Nc2cccc3cccnc23)c(C)c1</smiles>

\section{2',4',6' -Trimethyl- $N$-(quinolin-8-yl)-3-(trifluoromethyl)-[1,1'-biphenyl]-2-carboxamide (137gc):}

The general procedure D was followed using $N$-(quinolin-8-yl)-2-(trifluoromethyl)benzamide 9g $(65.5 \mathrm{mg}, 0.25 \mathrm{mmol})$ and mesityltrimethoxysilane $136 \mathrm{c}(120 \mathrm{mg}, 0.50 \mathrm{mmol})$. Isolation by column chromatography ( $n$-hexane/acetone: 10/1) yielded $137 \mathrm{gc}(51 \mathrm{mg}, 47 \%)$ as a white solid.

M. p. $=158-159^{\circ} \mathrm{C}$.

${ }^{1}$ H NMR $\left(400 \mathrm{MHz}, \mathrm{CDCl}_{3}\right): \delta=9.74\left(\mathrm{~s}_{\mathrm{br}}, 1 \mathrm{H}\right), 8.69(\mathrm{dd}, J=4.2,1.7 \mathrm{~Hz}, 1 \mathrm{H}), 8.58(\mathrm{dd}, J=6.1,2.9$ $\mathrm{Hz}, 1 \mathrm{H}), 8.08(\mathrm{dd}, J=8.3,1.7 \mathrm{~Hz}, 1 \mathrm{H}), 7.79-7.76(\mathrm{~m}, 1 \mathrm{H}), 7.62(\mathrm{td}, J=7.8,0.8 \mathrm{~Hz}, 1 \mathrm{H}), 7.44-7.37$ $(\mathrm{m}, 4 \mathrm{H}), 6.73(\mathrm{~d}, J=0.6 \mathrm{~Hz}, 2 \mathrm{H}), 2.10(\mathrm{~s}, 9 \mathrm{H})$.

${ }^{13}$ C NMR $\left(100 \mathrm{MHz}, \mathrm{CDCl}_{3}\right): \delta=164.7\left(\mathrm{C}_{\mathrm{q}}\right), 147.9(\mathrm{CH}), 140.6\left(\mathrm{C}_{\mathrm{q}}\right), 138.2\left(\mathrm{C}_{\mathrm{q}}\right), 137.3\left(\mathrm{C}_{\mathrm{q}}\right), 136.1$ $(\mathrm{CH}), 135.5\left(\mathrm{CH},{ }^{3} J_{\mathrm{C}-\mathrm{F}}=5.0 \mathrm{~Hz}\right), 134.9\left(\mathrm{C}_{\mathrm{q}}\right), 134.1\left(\mathrm{C}_{\mathrm{q}}\right), 134.0\left(\mathrm{C}_{\mathrm{q}}\right), 129.5(\mathrm{CH}), 128.0\left(\mathrm{C}_{\mathrm{q}},{ }^{2} J_{\mathrm{C}-\mathrm{F}}=\right.$ 31.3 Hz), $128.1(\mathrm{CH}), 127.7\left(\mathrm{C}_{\mathrm{q}}\right), 127.3(\mathrm{CH}), 125.2\left(\mathrm{CH},{ }^{3} J_{\mathrm{C}-\mathrm{F}}=11.2 \mathrm{~Hz}\right), 121.9\left(\mathrm{C}_{\mathrm{q}},{ }^{3} J_{\mathrm{C}-\mathrm{F}}=5.3 \mathrm{~Hz}\right)$, $121.7(\mathrm{CH}), 121.5(\mathrm{CH}), 118.3\left(\mathrm{C}_{\mathrm{q}},{ }^{1} J_{\mathrm{C}-\mathrm{F}}=279.3 \mathrm{~Hz}\right), 116.5(\mathrm{CH}), 20.9\left(\mathrm{CH}_{3}\right), 20.7\left(\mathrm{CH}_{3}\right)$.

${ }^{19}$ F NMR $\left(376 \mathrm{MHz}, \mathrm{CDCl}_{3}\right): \delta=-58.9$.

IR (ATR): 1682, 1528, 1485, 1117, 822, $693 \mathrm{~cm}^{-1}$.

MS (EI) $m / z$ (relative intensity): 434 (30) $[\mathrm{M}]^{+}, 291$ (20), 144 (100).

HR-MS (EI) $m / z$ calcd for $\mathrm{C}_{26} \mathrm{H}_{24} \mathrm{~N}_{2} \mathrm{O}^{+}[\mathrm{M}]^{+}$: 434.1606, found: 434.1606. 
<smiles>O=C(Nc1cccc2cccnc12)c1cc2ccccc2cc1-c1ccccc1</smiles>

\section{3-Phenyl- $N$-(quinolin-8-yl)-2-naphthamide (137ha):}

The general procedure $\mathbf{D}$ was followed using $N$-(quinolin-8-yl)-2-naphthamide 9 h $(74.5 \mathrm{mg}, 0.25$ $\mathrm{mmol}$ ) and trimethoxy(phenyl)silane 136a (99 $\mathrm{mg}, 0.50 \mathrm{mmol})$. Isolation by column chromatography ( $n$-hexane/acetone: $10 / 1)$ yielded $\mathbf{1 3 7 h a}(56 \mathrm{mg}, 60 \%)$ as a white solid.

M. p. $=200-201^{\circ} \mathrm{C}$.

${ }^{1}$ H NMR $\left(400 \mathrm{MHz}, \mathrm{CDCl}_{3}\right): \delta=9.80\left(\mathrm{~s}_{\mathrm{br}}, 1 \mathrm{H}\right), 8.90(\mathrm{dd}, J=7.6,1.3 \mathrm{~Hz}, 1 \mathrm{H}), 8.52(\mathrm{dd}, J=4.2,1.7$ $\mathrm{Hz}, 1 \mathrm{H}), 8.24-8.19(\mathrm{~m}, 1 \mathrm{H}), 8.06(\mathrm{dd}, J=8.3,1.7 \mathrm{~Hz}, 1 \mathrm{H}), 8.00(\mathrm{~d}, J=8.1 \mathrm{~Hz}, 1 \mathrm{H}), 7.92(\mathrm{td}, J=5.6$, $2.6 \mathrm{~Hz}, 1 \mathrm{H}), 7.65-7.62(\mathrm{~m}, 2 \mathrm{H}), 7.60(\mathrm{~d}, J=8.5 \mathrm{~Hz}, 1 \mathrm{H}), 7.56-7.51(\mathrm{~m}, 3 \mathrm{H}), 7.47(\mathrm{dd}, J=8.3,1.4$ $\mathrm{Hz}, 1 \mathrm{H}), 7.32$ (dd, $J=8.3,4.2 \mathrm{~Hz}, 1 \mathrm{H}), 7.26$ (dd, $J=8.5,2.9 \mathrm{~Hz}, 2 \mathrm{H}), 7.14-7.09$ (m, 1H).

${ }^{13} \mathrm{C}$ NMR $\left(100 \mathrm{MHz}, \mathrm{CDCl}_{3}\right): \delta=167.8\left(\mathrm{C}_{\mathrm{q}}\right), 148.0(\mathrm{CH}), 140.3\left(\mathrm{C}_{\mathrm{q}}\right), 138.4\left(\mathrm{C}_{\mathrm{q}}\right), 137.0\left(\mathrm{C}_{\mathrm{q}}\right), 136.0$ $(\mathrm{CH}), 134.5\left(\mathrm{C}_{\mathrm{q}}\right), 134.2\left(\mathrm{C}_{\mathrm{q}}\right), 133.8\left(\mathrm{C}_{\mathrm{q}}\right), 132.6\left(\mathrm{C}_{\mathrm{q}}\right), 130.5\left(\mathrm{C}_{\mathrm{q}}\right), 129.7(\mathrm{CH}), 128.9(\mathrm{CH}), 128.3(\mathrm{CH})$, $128.0(\mathrm{CH}), 127.8(\mathrm{CH}), 127.5(\mathrm{CH}), 127.4(\mathrm{CH}), 127.3(\mathrm{CH}), 126.4(\mathrm{CH}), 125.7(\mathrm{CH}), 121.8(\mathrm{CH})$, $121.4(\mathrm{CH}), 116.6(\mathrm{CH})$.

IR (ATR): 1667, 1518, 1482, 1325, 825, $790 \mathrm{~cm}^{-1}$.

MS (EI) $m / z$ (relative intensity): 374 (10) [M] ${ }^{+}, 231$ (60), 202 (30).

HR-MS (EI) $m / z$ calcd for $\mathrm{C}_{26} \mathrm{H}_{18} \mathrm{~N}_{2} \mathrm{O}^{+}[\mathrm{M}]^{+}: 374.1419$, found: 374.1417 .<smiles>Cc1cc(C)c(C(=O)Nc2cccc3cccnc23)c(-c2ccccc2)c1</smiles>

\section{3,5-Dimethyl- $N$-(quinolin-8-yl)-[1,1'-biphenyl]-2-carboxamide (137ia):}

The general procedure $\mathbf{D}$ was followed using 2,4-dimethyl- $N$-(quinolin-8-yl)benzamide 9i (69 g, 0.25 $\mathrm{mmol}$ ) and trimethoxy(phenyl)silane 136a (99 $\mathrm{mg}, 0.50 \mathrm{mmol})$. Isolation by column chromatography (n-hexane/Actone: 10/1) yielded 137ia (60 mg, 68\%) as a white solid. 
M. p. $=123-124^{\circ} \mathrm{C}$.

${ }^{1}$ H NMR (300 MHz, $\left.\mathrm{CDCl}_{3}\right): \delta=9.59\left(\mathrm{~s}_{\mathrm{br}}, 1 \mathrm{H}\right), 8.74(\mathrm{dd}, J=7.3,1.7 \mathrm{~Hz}, 1 \mathrm{H}), 8.57(\mathrm{dd}, J=4.2,1.7 \mathrm{~Hz}$, $1 \mathrm{H}), 8.05(\mathrm{dd}, J=8.3,1.7 \mathrm{~Hz}, 1 \mathrm{H}), 7.50(\mathrm{t}, J=1.7 \mathrm{~Hz}, 1 \mathrm{H}), 7.49-7.45(\mathrm{~m}, 2 \mathrm{H}), 7.42$ (dd, $J=8.3,1.7$ $\mathrm{Hz}, 1 \mathrm{H}), 7.33$ (dd, $J=8.3,4.2 \mathrm{~Hz}, 1 \mathrm{H}), 7.22-7.14(\mathrm{~m}, 2 \mathrm{H}), 7.10$ (s, 2H), 7.08-7.02 (m, 1H), 2.48 (s, $3 \mathrm{H}), 2.40(\mathrm{~s}, 3 \mathrm{H})$.

${ }^{13}$ C NMR $\left(125 \mathrm{MHz}, \mathrm{CDCl}_{3}\right): \delta=168.3\left(\mathrm{C}_{\mathrm{q}}\right), 147.8(\mathrm{CH}), 140.4\left(\mathrm{C}_{\mathrm{q}}\right), 139.6\left(\mathrm{C}_{\mathrm{q}}\right), 138.92\left(\mathrm{C}_{\mathrm{q}}\right), 138.3$ $\left(\mathrm{C}_{\mathrm{q}}\right), 135.9(\mathrm{CH}), 135.8\left(\mathrm{C}_{\mathrm{q}}\right), 134.4\left(\mathrm{C}_{\mathrm{q}}\right), 134.1\left(\mathrm{C}_{\mathrm{q}}\right), 130.1(\mathrm{CH}), 128.5(\mathrm{CH}), 128.2(\mathrm{CH}), 128.0(\mathrm{CH})$, $127.7\left(\mathrm{C}_{\mathrm{q}}\right), 127.2(\mathrm{CH}), 127.1(\mathrm{CH}), 121.4(\mathrm{CH}), 121.3(\mathrm{CH}), 116.3(\mathrm{CH}), 21.3\left(\mathrm{CH}_{3}\right), 19.8\left(\mathrm{CH}_{3}\right)$. IR (ATR): 1671, 1519, 1482, 1325, 826, $700 \mathrm{~cm}^{-1}$.

MS (EI) $m / z$ (relative intensity): $352(25)[\mathrm{M}]^{+}, 209$ (100), 165 (35).

HR-MS (EI) $m / z$ calcd for $\mathrm{C}_{24} \mathrm{H}_{20} \mathrm{~N}_{2} \mathrm{O}^{+}[\mathrm{M}]^{+}: 352.1576$, found: 352.1569 .<smiles>Cc1cc(C)c(C(=O)Nc2cccc3cccnc23)c(-c2c(C)cccc2C)c1</smiles>

\section{2',3,5,6'-Tetramethyl- $N$-(quinolin-8-yl)-[1,1'-biphenyl]-2-carboxamide (137ib):}

The general procedure $\mathbf{D}$ was followed using 2,4-dimethyl- $N$-(quinolin-8-yl)benzamide $9 \mathbf{i}$ ( $69 \mathrm{~g}, 0.25$ mmol) and (2,6-dimethylphenyl)trimethoxysilane $\mathbf{1 3 6 b}(113 \mathrm{mg}, 0.50 \mathrm{mmol})$. Isolation by column chromatography ( $n$-hexane/acetone: $10 / 1)$ yielded $137 i b(66.5,70 \%)$ as a white solid.

M. p. $=137-138^{\circ} \mathrm{C}$

${ }^{1}$ H NMR (400 MHz, $\left.\mathrm{CDCl}_{3}\right): \delta=9.62\left(\mathrm{~s}_{\mathrm{br}}, 1 \mathrm{H}\right), 8.69(\mathrm{dd}, J=4.2,1.7 \mathrm{~Hz}, 1 \mathrm{H}), 8.65(\mathrm{dd}, J=6.2,2.8 \mathrm{~Hz}$, $1 \mathrm{H}), 8.06(\mathrm{dd}, J=8.3,1.7 \mathrm{~Hz}, 1 \mathrm{H}), 7.42-7.39(\mathrm{~m}, 2 \mathrm{H}), 7.37$ (dd, $J=8.3,4.2 \mathrm{~Hz}, 1 \mathrm{H}), 7.12-7.09$ (m, 1H), 6.90 (s, 3H), 6.84 (dd, $J=1.0,0.6 \mathrm{~Hz}, 1 \mathrm{H}), 2.47$ (s, 3H), 2.39 (s, 3H), 2.19 (s, 6H).

${ }^{13} \mathrm{C}$ NMR $\left(100 \mathrm{MHz}, \mathrm{CDCl}_{3}\right): \delta=168.0\left(\mathrm{C}_{\mathrm{q}}\right), 147.7(\mathrm{CH}), 139.5\left(\mathrm{C}_{\mathrm{q}}\right), 139.0\left(\mathrm{C}_{\mathrm{q}}\right), 138.4\left(\mathrm{C}_{\mathrm{q}}\right), 138.3$ $\left(\mathrm{C}_{\mathrm{q}}\right), 136.2\left(\mathrm{C}_{\mathrm{q}}\right), 136.1(\mathrm{CH}), 135.6\left(\mathrm{C}_{\mathrm{q}}\right), 134.7\left(\mathrm{C}_{\mathrm{q}}\right), 134.4\left(\mathrm{C}_{\mathrm{q}}\right), 130.0(\mathrm{CH}), 127.7\left(\mathrm{C}_{\mathrm{q}}\right), 127.6(\mathrm{CH})$, $127.3(\mathrm{CH}), 127.1(\mathrm{CH}), 127.1(\mathrm{CH}), 121.4(\mathrm{CH}), 121.3(\mathrm{CH}), 116.2(\mathrm{CH}), 21.3\left(\mathrm{CH}_{3}\right), 20.8\left(\mathrm{CH}_{3}\right)$, $19.8\left(\mathrm{CH}_{3}\right)$.

IR (ATR): 1671, 1518, 1482, 1325, 858, $770 \mathrm{~cm}^{-1}$. 
MS (EI) $m / z$ (relative intensity): $380(20)[\mathrm{M}]^{+}, 237$ (80), 179 (35), 144 (40).

HR-MS (EI) $m / z$ calcd for $\mathrm{C}_{26} \mathrm{H}_{24} \mathrm{~N}_{2} \mathrm{O}^{+}[\mathrm{M}]^{+}: 380.1889$, found: 380.1894 .<smiles>Cc1ccccc1-c1cccc(C)c1C(=O)Nc1cccc2cccnc12</smiles>

\section{2',3-Dimethyl- $N$-(quinolin-8-yl)-[1,1'-biphenyl]-2-carboxamide (137ad):}

The general procedure $\mathbf{D}$ was followed using 2-methyl- $N$-(quinolin-8-yl)benzamide 9a $(65.5 \mathrm{mg}$, $0.25 \mathrm{mmol})$ and trimethoxy $(o-$ tolyl $)$ silane $\mathbf{1 3 6 d}(106 \mathrm{mg}, 0.50 \mathrm{mmol})$. Isolation by column chromatography ( $n$-hexane/acetone: 10/1) yielded 137ad (70.4 mg, 80\%) as a white solid.

M. p. $=115-116^{\circ} \mathrm{C}$

${ }^{1}$ H NMR (400 MHz, $\left.\mathrm{CDCl}_{3}\right): \delta=9.61\left(\mathrm{~s}_{\mathrm{br}}, 1 \mathrm{H}\right), 8.67(\mathrm{dt}, J=2.9,1.4 \mathrm{~Hz}, 1 \mathrm{H}), 8.65(\mathrm{dd}, J=6.3,2.7 \mathrm{~Hz}$, $1 \mathrm{H}), 8.07(\mathrm{dd}, J=8.3,1.7 \mathrm{~Hz}, 1 \mathrm{H}), 7.43-7.41(\mathrm{~m}, 2 \mathrm{H}), 7.40-7.34(\mathrm{~m}, 2 \mathrm{H}), 7.30-7.28(\mathrm{~m}, 1 \mathrm{H}), 7.28-$ 7.25 (m, 1H), 7.14 (ddd, $J=7.6,1.2,0.6 \mathrm{~Hz}, 1 \mathrm{H}), 7.06-7.02(\mathrm{~m}, 1 \mathrm{H}), 6.99-6.95(\mathrm{~m}, 2 \mathrm{H}), 2.52$ (s, 3H), $2.28(\mathrm{~s}, 3 \mathrm{H})$.

${ }^{13}$ C NMR $\left(100 \mathrm{MHz}, \mathrm{CDCl}_{3}\right): \delta=167.8\left(\mathrm{C}_{\mathrm{q}}\right), 147.8(\mathrm{CH}), 139.7\left(\mathrm{C}_{\mathrm{q}}\right), 139.3\left(\mathrm{C}_{\mathrm{q}}\right), 138.3\left(\mathrm{C}_{\mathrm{q}}\right), 137.5$ $\left(\mathrm{C}_{\mathrm{q}}\right), 136.1(\mathrm{CH}), 135.9\left(\mathrm{C}_{\mathrm{q}}\right), 135.6\left(\mathrm{C}_{\mathrm{q}}\right), 134.3\left(\mathrm{C}_{\mathrm{q}}\right), 129.9(\mathrm{CH}), 129.6(\mathrm{CH}), 129.3(\mathrm{CH}), 128.7(\mathrm{CH})$, $127.7\left(\mathrm{C}_{\mathrm{q}}\right), 127.6(\mathrm{CH}), 127.4(\mathrm{CH}), 127.3(\mathrm{CH}), 125.2(\mathrm{CH}), 121.4(\mathrm{CH}), 121.4(\mathrm{CH}), 116.2(\mathrm{CH})$, $20.3\left(\mathrm{CH}_{3}\right), 19.8\left(\mathrm{CH}_{3}\right)$.

IR (ATR): 1673, 1519, 1482, 1325, 899, $790 \mathrm{~cm}^{-1}$.

MS (EI) $m / z$ (relative intensity): 352 (15) [M] ${ }^{+}, 209$ (100), 165 (55), 144 (70).

HR-MS (EI) $m / z$ calcd for $\mathrm{C}_{24} \mathrm{H}_{20} \mathrm{~N}_{2} \mathrm{O}^{+}[\mathrm{M}]^{+}: 353.1576$, found: 352.1586 . 
<smiles>COc1cccc(-c2cccc(C)c2C(=O)Nc2cccc3cccnc23)c1</smiles>

\section{3'-Methoxy-3-methyl- $N$-(quinolin-8-yl)-[1,1'-biphenyl]-2-carboxamide (137ae):}

The general procedure D was followed using 2-methyl- $N$-(quinolin-8-yl)benzamide 9a (65.5 mg, $0.25 \mathrm{mmol}$ ) and trimethoxy(3-methoxyphenyl)silane 136e (114 $\mathrm{mg}, 0.50 \mathrm{mmol})$. Isolation by column chromatography ( $n$-hexane/acetone: 10/1) yielded 137ae (61 mg, 66\%) as a white solid.

M. p. $=102-103{ }^{\circ} \mathrm{C}$

${ }^{1}$ H NMR $\left(300 \mathrm{MHz}, \mathrm{CDCl}_{3}\right): \delta=9.66\left(\mathrm{~s}_{\mathrm{br}}, 1 \mathrm{H}\right), 8.80-8.76(\mathrm{~m}, 1 \mathrm{H}), 8.59(\mathrm{dd}, J=4.2,1.7 \mathrm{~Hz}, 1 \mathrm{H}), 8.05$ $(\mathrm{dd}, J=8.3,1.7 \mathrm{~Hz}, 1 \mathrm{H}), 7.52-7.45(\mathrm{~m}, 2 \mathrm{H}), 7.41(\mathrm{dd}, J=6.1,3.1 \mathrm{~Hz}, 1 \mathrm{H}), 7.38-7.34(\mathrm{~m}, 1 \mathrm{H}), 7.32(\mathrm{t}$, $J=3.1 \mathrm{~Hz}, 1 \mathrm{H}), 7.31-7.26(\mathrm{~m}, 1 \mathrm{H}), 7.11-7.06(\mathrm{~m}, 3 \mathrm{H}), 6.62(\mathrm{ddd}, J=5.1,4.0,2.1 \mathrm{~Hz}, 1 \mathrm{H}), 3.63(\mathrm{~s}$, $3 \mathrm{H}), 2.52(\mathrm{~s}, 3 \mathrm{H})$.

${ }^{13}$ C NMR $\left(125 \mathrm{MHz}, \mathrm{CDCl}_{3}\right): \delta=168.2\left(\mathrm{C}_{\mathrm{q}}\right), 159.2\left(\mathrm{C}_{\mathrm{q}}\right), 147.8(\mathrm{CH}), 141.6\left(\mathrm{C}_{\mathrm{q}}\right), 139.5\left(\mathrm{C}_{\mathrm{q}}\right), 138.3$ $\left(\mathrm{C}_{\mathrm{q}}\right), 136.7\left(\mathrm{C}_{\mathrm{q}}\right), 136.0(\mathrm{CH}), 135.8\left(\mathrm{C}_{\mathrm{q}}\right), 134.3\left(\mathrm{C}_{\mathrm{q}}\right), 129.5(\mathrm{CH}), 129.1(\mathrm{CH}), 129.1(\mathrm{CH}), 127.7\left(\mathrm{C}_{\mathrm{q}}\right)$, 127.4 (CH), $127.1(\mathrm{CH}), 121.6(\mathrm{CH}), 121.3(\mathrm{CH}), 121.1(\mathrm{CH}), 116.3(\mathrm{CH}), 113.6(\mathrm{CH}), 107.8(\mathrm{CH})$, $55.1\left(\mathrm{CH}_{3}\right), 19.8\left(\mathrm{CH}_{3}\right)$.

IR (ATR): 1671, 1520, 1482, 1264, 730, $700 \mathrm{~cm}^{-1}$.

MS (EI) $m / z$ (relative intensity): 368 (40) [M] $]^{+}, 225$ (100), 144 (60).

HR-MS (EI) $m / z$ calcd for $\mathrm{C}_{24} \mathrm{H}_{20} \mathrm{~N}_{2} \mathrm{O}_{2}{ }^{+}[\mathrm{M}]^{+}:$368.1525, found: 368.1526. 
<smiles>Cc1ccc(-c2cccc(C)c2C(=O)Nc2cccc3cccnc23)cc1</smiles>

\section{3,4'-Dimethyl- $N$-(quinolin-8-yl)-[1,1'-biphenyl]-2-carboxamide (137af):}

The general procedure D was followed using 2-methyl- $N$-(quinolin-8-yl)benzamide 9a (65.5 mg, $0.25 \mathrm{mmol})$ and trimethoxy $(p$-tolyl $)$ silane $136 f(106 \mathrm{mg}, 0.50 \mathrm{mmol})$. Isolation by column chromatography ( $\mathrm{n}$-hexane/acetone: $10 / 1)$ yielded 137af (55 mg, 62\%) as a white solid.

M. p. $=118-119^{\circ} \mathrm{C}$.

${ }^{1}$ H NMR $\left(400 \mathrm{MHz}, \mathrm{CDCl}_{3}\right): \delta=9.62\left(\mathrm{~s}_{\mathrm{br}}, 1 \mathrm{H}\right), 8.78(\mathrm{dd}, J=7.4,1.5 \mathrm{~Hz}, 1 \mathrm{H}), 8.60(\mathrm{dd}, J=4.2,1.7 \mathrm{~Hz}$, 1H), 8.07 (dd, $J=8.3,1.7 \mathrm{~Hz}, 1 \mathrm{H}), 7.52-7.47$ (m, 1H), 7.46-7.43 (m, 3H), 7.39-7.32 (m, 2H), 7.297.24 (m, 2H), 6.75-6.72 (m, 2H), 3.61 (s, 3H), 2.51 (s, 3H).

${ }^{13}$ C NMR $\left(100 \mathrm{MHz}, \mathrm{CDCl}_{3}\right): \delta=168.5\left(\mathrm{C}_{\mathrm{q}}\right), 158.9\left(\mathrm{C}_{\mathrm{q}}\right), 148.0(\mathrm{CH}), 139.3\left(\mathrm{C}_{\mathrm{q}}\right), 138.4\left(\mathrm{C}_{\mathrm{q}}\right), 136.8$ $\left(\mathrm{C}_{\mathrm{q}}\right), 136.1(\mathrm{CH}), 135.8\left(\mathrm{C}_{\mathrm{q}}\right), 134.5\left(\mathrm{C}_{\mathrm{q}}\right), 132.8\left(\mathrm{C}_{\mathrm{q}}\right), 129.8(\mathrm{CH}), 129.1(\mathrm{CH}), 129.1(\mathrm{CH}), 127.8\left(\mathrm{C}_{\mathrm{q}}\right)$, 127.6 (CH), $127.2(\mathrm{CH}), 121.6(\mathrm{CH}), 121.4(\mathrm{CH}), 116.5(\mathrm{CH}), 113.7(\mathrm{CH}), 55.1\left(\mathrm{CH}_{3}\right), 19.8\left(\mathrm{CH}_{3}\right)$. IR (ATR): 1666, 1514, 1244, 1176, 786, $569 \mathrm{~cm}^{-1}$.

MS (EI) $m / z$ (relative intensity): $352(20)[\mathrm{M}]^{+}, 208(80), 180$ (40).

HR-MS (ESI) $m / z$ calcd for $\mathrm{C}_{24} \mathrm{H}_{20} \mathrm{~N}_{2} \mathrm{O}^{+}[\mathrm{M}]^{+}: 352.1576$, found: 352.1574 .<smiles>COc1ccc(-c2cccc(C)c2C(=O)Nc2cccc3cccnc23)cc1</smiles>

\section{4'-Methoxy-3-methyl- $N$-(quinolin-8-yl)-[1,1'-biphenyl]-2-carboxamide (137ag):}

The general procedure D was followed using 2-methyl- $N$-(quinolin-8-yl)benzamide 9a $(65.5 \mathrm{mg}$, $0.25 \mathrm{mmol}$ ) and trimethoxy(4-methoxyphenyl)silane $136 \mathrm{~g}(114 \mathrm{mg}, 0.50 \mathrm{mmol})$. Isolation by column chromatography ( $n$-hexane/acetone: $10 / 1)$ yielded 137ag (58 mg, 63\%) as a white solid.

M. p. $=150-151{ }^{\circ} \mathrm{C}$ 
${ }^{1}$ H NMR $\left(400 \mathrm{MHz}, \mathrm{CDCl}_{3}\right): \delta=9.63\left(\mathrm{~s}_{\mathrm{br}}, 1 \mathrm{H}\right), 8.78(\mathrm{dd}, J=7.4,1.5 \mathrm{~Hz}, 1 \mathrm{H}), 8.60(\mathrm{dd}, J=4.2,1.7 \mathrm{~Hz}$, $1 \mathrm{H}), 8.06(\mathrm{dd}, J=8.3,1.7 \mathrm{~Hz}, 1 \mathrm{H}), 7.52-7.47(\mathrm{~m}, 1 \mathrm{H}), 7.46-7.42(\mathrm{~m}, 3 \mathrm{H}), 7.39-7.32(\mathrm{~m}, 2 \mathrm{H}), 7.28-$ $7.25(\mathrm{~m}, 2 \mathrm{H}), 6.76-6.74(\mathrm{~m}, 1 \mathrm{H}), 6.73-6.72(\mathrm{~m}, 1 \mathrm{H}), 3.61(\mathrm{~s}, 3 \mathrm{H}), 2.51(\mathrm{~s}, 3 \mathrm{H})$.

${ }^{13}$ C NMR $\left(100 \mathrm{MHz}, \mathrm{CDCl}_{3}\right): \delta=168.5\left(\mathrm{C}_{\mathrm{q}}\right), 158.9\left(\mathrm{C}_{\mathrm{q}}\right), 148.0(\mathrm{CH}), 139.2\left(\mathrm{C}_{\mathrm{q}}\right), 138.4\left(\mathrm{C}_{\mathrm{q}}\right), 136.8$ $\left(\mathrm{C}_{\mathrm{q}}\right), 136.1(\mathrm{CH}), 135.7\left(\mathrm{C}_{\mathrm{q}}\right), 134.4\left(\mathrm{C}_{\mathrm{q}}\right), 132.8\left(\mathrm{C}_{\mathrm{q}}\right), 129.8(\mathrm{CH}), 129.12(\mathrm{CH}), 129.13(\mathrm{CH}), 127.8$ $\left(\mathrm{C}_{\mathrm{q}}\right), 127.6(\mathrm{CH}), 127.2(\mathrm{CH}), 121.6(\mathrm{CH}), 121.4(\mathrm{CH}), 116.5(\mathrm{CH}), 113.7(\mathrm{CH}), 55.1\left(\mathrm{CH}_{3}\right), 19.8$ $\left(\mathrm{CH}_{3}\right)$.

IR (ATR): 1673, 1519, 1482, 1245, 791, $665 \mathrm{~cm}^{-1}$.

MS (EI) $m / z$ (relative intensity): $368(30)\left[\mathrm{M}^{+}, 225(100)\right.$.

HR-MS (EI) $m / z$ calcd for $\mathrm{C}_{24} \mathrm{H}_{20} \mathrm{~N}_{2} \mathrm{O}_{2}{ }^{+}[\mathrm{M}]^{+}: 368.1525$, found: 368.1528 .<smiles>Cc1cccc(-c2ccc(C(F)(F)F)cc2)c1C(=O)Nc1cccc2cccnc12</smiles>

\section{3-Methyl- $N$-(quinolin-8-yl)-4' -(trifluoromethyl)-[1,1'-biphenyl]-2-carboxamide (132ah):}

The general procedure D was followed using 2-methyl- $N$-(quinolin-8-yl)benzamide 9a (65.5 mg, $0.25 \mathrm{mmol}$ ) and trimethoxy(4-(trifluoromethyl)phenyl)silane $\mathbf{1 3 6 h}(133 \mathrm{mg}, 0.50 \mathrm{mmol})$. Isolation by column chromatography ( $n$-hexane/Actone: 10/1) yielded 137ah (89 $\mathrm{mg}, 88 \%)$ as a colorless oil. ${ }^{1} \mathbf{H}$ NMR $\left(300 \mathrm{MHz}, \mathrm{CDCl}_{3}\right): \delta=9.62\left(\mathrm{~s}_{\mathrm{br}}, 1 \mathrm{H}\right), 8.72(\mathrm{dd}, J=6.7,2.3 \mathrm{~Hz}, 1 \mathrm{H}), 8.58(\mathrm{dd}, J=4.2,1.7 \mathrm{~Hz}$, 1H), 8.10-8.06 (m, 1H), $7.62(\mathrm{dd}, J=8.7,0.7 \mathrm{~Hz}, 2 \mathrm{H}), 7.49(\mathrm{dd}, J=4.5,3.4 \mathrm{~Hz}, 2 \mathrm{H}), 7.43(\mathrm{~m}, 3 \mathrm{H})$, $7.38(\mathrm{dd}, J=8.5,3.8 \mathrm{~Hz}, 1 \mathrm{H}), 7.34(\mathrm{dd}, J=2.5,1.7 \mathrm{~Hz}, 1 \mathrm{H}), 7.30-7.26(\mathrm{~m}, 1 \mathrm{H}), 2.54(\mathrm{~s}, 3 \mathrm{H})$.

${ }^{13}$ C NMR $\left(125 \mathrm{MHz}, \mathrm{CDCl}_{3}\right): \delta=167.8\left(\mathrm{C}_{\mathrm{q}}\right), 148.0(\mathrm{CH}), 144.0\left(\mathrm{C}_{\mathrm{q}}\right), 138.2\left(\mathrm{C}_{\mathrm{q}}\right), 136.7\left(\mathrm{C}_{\mathrm{q}}\right), 136.3$ $\left(\mathrm{C}_{\mathrm{q}}\right), 136.1(\mathrm{CH}), 134.0\left(\mathrm{C}_{\mathrm{q}}\right), 130.3(\mathrm{CH}), 129.4(\mathrm{CH}), 129.2\left(\mathrm{C}_{\mathrm{q}},{ }^{2} J_{\mathrm{C}-\mathrm{F}}=32.5 \mathrm{~Hz}\right), 129.0(\mathrm{CH}), 127.8$ $\left(\mathrm{C}_{\mathrm{q}}\right), 127.5(\mathrm{CH}), 127.2(\mathrm{CH}), 125.1\left(\mathrm{CH},{ }^{3} J_{\mathrm{C}-\mathrm{F}}=7.9 \mathrm{~Hz}\right), 123.9\left(\mathrm{C}_{\mathrm{q}},{ }^{1} J_{\mathrm{C}-\mathrm{F}}=270.3 \mathrm{~Hz}\right), 122.9\left(\mathrm{C}_{\mathrm{q}}\right)$, $122.0(\mathrm{CH}), 121.5(\mathrm{CH}), 116.8(\mathrm{CH}), 19.8\left(\mathrm{CH}_{3}\right)$.

${ }^{19}$ F NMR $\left(282 \mathrm{MHz}, \mathrm{CDCl}_{3}\right): \delta=-62.7$.

IR (ATR): 1671, 1518, 1481, 1321, 1061, 825, $606 \mathrm{~cm}^{-1}$.

MS (EI) $m / z$ (relative intensity): $406(30)[\mathrm{M}]^{+}, 263$ (70), 165 (20).

HR-MS (EI) $m / z$ calcd for $\mathrm{C}_{24} \mathrm{H}_{17} \mathrm{~F}_{3} \mathrm{~N}_{2} \mathrm{O}^{+}[\mathrm{M}]^{+}:$406.1293, found: 406.1294. 
<smiles>Cc1ccc(-c2ccccc2C(=O)Nc2cccc3cccnc23)cc1</smiles>

\section{4'-Methyl- $N$-(quinolin-8-yl)-[1,1'-biphenyl]-2-carboxamide (137bi):}

The general procedure $\mathbf{D}$ was followed using $N$-(quinolin-8-yl)benzamide $9 \mathbf{b}$ (62 $\mathrm{mg}, 0.25 \mathrm{mmol}$ ) and trimethoxy(p-tolyl)silane 136i $(100 \mu \mathrm{L}, 0.50 \mathrm{mmol})$. Isolation by column chromatography ( $n$-hexane/acetone: 10/1) yielded 137bi (46 mg, 54\%) as a white solid.

M. p. $=115-116^{\circ} \mathrm{C}$

${ }^{1}$ H NMR (300 MHz, $\left.\mathrm{CDCl}_{3}\right): \delta=9.79\left(\mathrm{~s}_{\mathrm{br}}, 1 \mathrm{H}\right), 8.80(\mathrm{dd}, J=7.4,1.5 \mathrm{~Hz}, 1 \mathrm{H}), 8.51(\mathrm{dd}, J=4.2,1.7 \mathrm{~Hz}$, $1 \mathrm{H}), 8.07(\mathrm{dd}, J=8.3,1.7 \mathrm{~Hz}, 1 \mathrm{H}), 7.90-7.85(\mathrm{~m}, 1 \mathrm{H}), 7.53(\mathrm{~m}, 2 \mathrm{H}), 7.49-7.43(\mathrm{~m}, 4 \mathrm{H}), 7.42-7.40(\mathrm{~m}$, $1 \mathrm{H}), 7.34$ (dd, $J=8.3,4.2 \mathrm{~Hz}, 1 \mathrm{H}), 6.83-6.77(\mathrm{~m}, 2 \mathrm{H}), 3.64(\mathrm{~s}, 3 \mathrm{H})$.

${ }^{13}$ C NMR (125 MHz, $\left.\mathrm{CDCl}_{3}\right): \delta=168.1\left(\mathrm{C}_{\mathrm{q}}\right), 159.3\left(\mathrm{C}_{\mathrm{q}}\right), 147.7(\mathrm{CH}), 139.9\left(\mathrm{C}_{\mathrm{q}}\right), 138.5\left(\mathrm{C}_{\mathrm{q}}\right), 136.0$ $(\mathrm{CH}), 135.9\left(\mathrm{C}_{\mathrm{q}}\right), 134.6\left(\mathrm{C}_{\mathrm{q}}\right), 132.4\left(\mathrm{C}_{\mathrm{q}}\right), 130.6(\mathrm{CH}), 130.5(\mathrm{CH}), 130.1(\mathrm{CH}), 129.3(\mathrm{CH}), 127.7$ $\left(\mathrm{C}_{\mathrm{q}}\right), 127.3(\mathrm{CH}), 127.2(\mathrm{CH}), 121.5(\mathrm{CH}), 121.4(\mathrm{CH}), 116.3(\mathrm{CH}), 113.9(\mathrm{CH}), 55.1\left(\mathrm{CH}_{3}\right)$.

IR (ATR): 1663, 1517, 1481, 1245, 826, $762 \mathrm{~cm}^{-1}$.

MS (EI) $m / z$ (relative intensity): $338(30)[\mathrm{M}]^{+}, 195(80), 165$ (30).

HR-MS (EI) $m / z$ calcd for $\mathrm{C}_{23} \mathrm{H}_{18} \mathrm{~N}_{2} \mathrm{O}^{+}[\mathrm{M}]^{+}: 338.1419$, found: 338.1416 .<smiles>Cc1cccc(-c2c(C)cccc2C)c1C(=O)Nc1cccc2cccnc12</smiles>

\section{2',3,6'-Trimethyl- $N$-(quinolin-8-yl)-[1,1'-biphenyl]-2-carboxamide (137ab):}

The general procedure D was followed using 2-methyl- $N$-(quinolin-8-yl)benzamide 9a $(65.5 \mathrm{mg}$, $0.25 \mathrm{mmol})$ and (2,6-dimethylphenyl)trimethoxysilane $136 \mathbf{b}(113 \mathrm{mg}, 0.50 \mathrm{mmol})$. Isolation by column chromatography ( $n$-hexane/acetone: $10 / 1)$ yielded $137 \mathbf{a b}(57 \mathrm{mg}, 62 \%)$ as a white solid. M. p. $=128-129^{\circ} \mathrm{C}$. 
${ }^{1}$ H NMR $\left(300 \mathrm{MHz}, \mathrm{CDCl}_{3}\right): \delta=9.63\left(\mathrm{~s}_{\mathrm{br}}, 1 \mathrm{H}\right), 8.69(\mathrm{dd}, J=4.2,1.7 \mathrm{~Hz}, 1 \mathrm{H}), 8.66-8.62(\mathrm{~m}, 1 \mathrm{H}), 8.08$ $(\mathrm{dd}, J=8.3,1.7 \mathrm{~Hz}, 1 \mathrm{H}), 7.43(\mathrm{~d}, J=0.9 \mathrm{~Hz}, 1 \mathrm{H}), 7.41(\mathrm{~s}, 1 \mathrm{H}), 7.41-7.36(\mathrm{~m}, 2 \mathrm{H}), 7.28(\mathrm{dd}, J=7.7$, $1.2 \mathrm{~Hz}, 1 \mathrm{H}), 7.05-7.01(\mathrm{~m}, 1 \mathrm{H}), 6.90(\mathrm{~s}, 3 \mathrm{H}), 2.50$ (s, 3H), 2.17 (s, 6H).

${ }^{13}$ C NMR (125 MHz, $\left.\mathrm{CDCl}_{3}\right): \delta=167.6\left(\mathrm{C}_{\mathrm{q}}\right), 147.5(\mathrm{CH}), 139.3\left(\mathrm{C}_{\mathrm{q}}\right), 138.3\left(\mathrm{C}_{\mathrm{q}}\right), 138.2\left(\mathrm{C}_{\mathrm{q}}\right), 137.3$ $\left(\mathrm{C}_{\mathrm{q}}\right), 136.2\left(\mathrm{C}_{\mathrm{q}}\right), 136.0(\mathrm{CH}), 135.5\left(\mathrm{C}_{\mathrm{q}}\right), 134.3\left(\mathrm{C}_{\mathrm{q}}\right), 129.2(\mathrm{CH}), 129.1(\mathrm{CH}), 127.7\left(\mathrm{C}_{\mathrm{q}}\right), 127.2(\mathrm{CH})$, $127.2(\mathrm{CH}), 127.1(\mathrm{CH}), 127.0(\mathrm{CH}), 121.4(\mathrm{CH}), 121.3(\mathrm{CH}), 116.2(\mathrm{CH}), 20.9\left(\mathrm{CH}_{3}\right), 19.9\left(\mathrm{CH}_{3}\right)$. IR (ATR): 1665, 1523, 1481, 1384, 825, $762 \mathrm{~cm}^{-1}$.

MS (EI) $m / z$ (relative intensity): $366(35)[\mathrm{M}]^{+}, 223$ (100), 165 (50).

HR-MS (EI) $m / z$ calcd for $\mathrm{C}_{25} \mathrm{H}_{22} \mathrm{~N}_{2} \mathrm{O}^{+}[\mathrm{M}]^{+}: 366.1732$, found: 366.1737 .

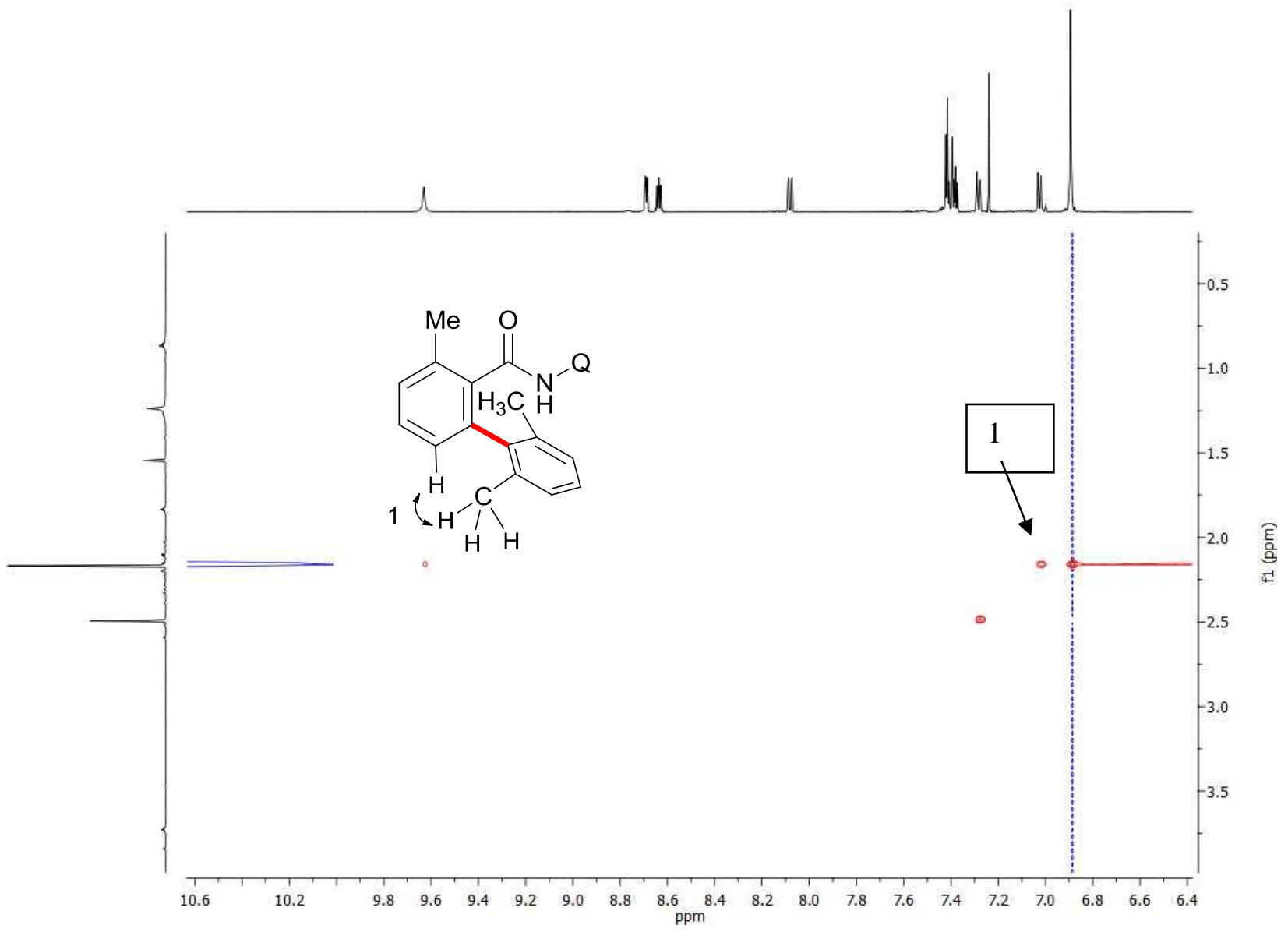


<smiles>Cc1cc(C)c(-c2cccc(C)c2C(=O)Nc2cccc3cccnc23)c(C)c1</smiles>

\section{2',3,4',6'-Tetramethyl- $N$-(quinolin-8-yl)-[1,1'-biphenyl]-2-carboxamide (137ac):}

The general procedure D was followed using 2-methyl- $N$-(quinolin-8-yl)benzamide 9a (65.5 mg, $0.25 \mathrm{mmol})$ and mesityltrimethoxysilane $136 \mathrm{c}(120 \mathrm{mg}, 0.50 \mathrm{mmol})$. Isolation by column chromatography ( $n$-hexane/acetone: $10 / 1)$ yielded 137 ac $(60 \mathrm{mg}, 63 \%)$ as a white solid.

M. p. $=156-157^{\circ} \mathrm{C}$.

${ }^{1}$ H NMR $\left(400 \mathrm{MHz}, \mathrm{CDCl}_{3}\right): \delta=9.65\left(\mathrm{~s}_{\mathrm{br}}, 1 \mathrm{H}\right), 8.69(\mathrm{dd}, J=4.2,1.7 \mathrm{~Hz}, 1 \mathrm{H}), 8.67(\mathrm{dd}, J=5.7,3.3$ $\mathrm{Hz}, 1 \mathrm{H}), 8.09$ (dd, $J=8.3,1.7 \mathrm{~Hz}, 1 \mathrm{H}), 7.44-7.42(\mathrm{~m}, 2 \mathrm{H}), 7.41-7.36$ (m, 2H), 7.27 (ddd, $J=7.6$, 1.2, $0.7 \mathrm{~Hz}, 1 \mathrm{H}), 7.01(\mathrm{dd}, J=7.6,1.2,0.6 \mathrm{~Hz}, 1 \mathrm{H}), 6.72(\mathrm{~d}, J=0.6 \mathrm{~Hz}, 2 \mathrm{H}), 2.49$ (s, 3H), 2.13 (s, $6 \mathrm{H}), 2.09$ (s, 3H).

${ }^{13}$ C NMR (100 MHz, $\left.\mathrm{CDCl}_{3}\right): \delta=167.9\left(\mathrm{C}_{\mathrm{q}}\right), 147.8(\mathrm{CH}), 138.5\left(\mathrm{C}_{\mathrm{q}}\right), 138.3\left(\mathrm{C}_{\mathrm{q}}\right), 137.7\left(\mathrm{C}_{\mathrm{q}}\right), 136.6$ $\left(\mathrm{C}_{\mathrm{q}}\right), 136.5\left(\mathrm{C}_{\mathrm{q}}\right), 136.12\left(\mathrm{C}_{\mathrm{q}}\right), 136.11(\mathrm{CH}), 135.5\left(\mathrm{C}_{\mathrm{q}}\right), 134.4\left(\mathrm{C}_{\mathrm{q}}\right), 129.2(\mathrm{CH}), 129.1(\mathrm{CH}), 127.9$ $(\mathrm{CH}), 127.8\left(\mathrm{C}_{\mathrm{q}}\right), 127.5(\mathrm{CH}), 127.3(\mathrm{CH}), 121.5(\mathrm{CH}), 121.4(\mathrm{CH}), 116.3(\mathrm{CH}), 20.9\left(\mathrm{CH}_{3}\right), 20.7$ $\left(\mathrm{CH}_{3}\right), 19.8\left(\mathrm{CH}_{3}\right)$.

IR (ATR): 1672, 1518, 1481, 1325, 790, $729 \mathrm{~cm}^{-1}$.

MS (EI) $m / z$ (relative intensity): 380 (30) [M] ${ }^{+}, 237$ (90), 179 (45), 144 (100).

HR-MS (ESI) $m / z$ calcd for $\mathrm{C}_{26} \mathrm{H}_{24} \mathrm{~N}_{2} \mathrm{O}^{+}[\mathrm{M}]^{+}: 380.1883$, found: 380.1875 . 
<smiles>Cc1cccc(-c2cccc3ccccc23)c1C(=O)Nc1cccc2cccnc12</smiles>

\section{2-Methyl-6-(naphthalen-1-yl)- $N$-(quinolin-8-yl)benzamide (137aj):}

The general procedure D was followed using 2-methyl- $N$-(quinolin-8-yl)benzamide 9a (65.5 mg, $0.25 \mathrm{mmol}$ ) and trimethoxy(naphthalen-1-yl)silane $\mathbf{1 3 1} \mathbf{j}(124 \mathrm{mg}, 0.50 \mathrm{mmol})$. Isolation by column chromatography ( $n$-hexane/acetone: 10/1) yielded 132aj (78 mg, 80\%) as a white solid.

M. p. $=215-216^{\circ} \mathrm{C}$.

${ }^{1} \mathbf{H}$ NMR $\left(400 \mathrm{MHz}, \mathrm{CDCl}_{3}\right): \delta=9.52\left(\mathrm{~s}_{\mathrm{br}}, 1 \mathrm{H}\right), 8.51(\mathrm{dd}, J=6.8,2.1 \mathrm{~Hz}, 1 \mathrm{H}), 8.29(\mathrm{dd}, J=4.2,1.6 \mathrm{~Hz}$, 1H), $7.93(\mathrm{dd}, J=8.3,1.6 \mathrm{~Hz}, 1 \mathrm{H}), 7.86(\mathrm{~d}, J=8.3 \mathrm{~Hz}, 1 \mathrm{H}), 7.64(\mathrm{~d}, J=8.3 \mathrm{~Hz}, 1 \mathrm{H}), 7.53(\mathrm{~d}, J=8.3 \mathrm{~Hz}$, 1H), $7.50(\mathrm{~d}, J=7.1 \mathrm{~Hz}, 1 \mathrm{H}), 7.47-7.45(\mathrm{~m}, 1 \mathrm{H}), 7.43(\mathrm{~d}, J=7.5 \mathrm{~Hz}, 1 \mathrm{H}), 7.40-7.32(\mathrm{~m}, 3 \mathrm{H}), 7.31(\mathrm{~d}$, $J=1.9 \mathrm{~Hz}, 2 \mathrm{H}), 7.29-7.26(\mathrm{~m}, 1 \mathrm{H}), 7.22(\mathrm{dd}, J=8.3,4.2 \mathrm{~Hz}, 1 \mathrm{H}), 2.57$ (s, 3H).

${ }^{13} \mathrm{C}$ NMR $\left(100 \mathrm{MHz}, \mathrm{CDCl}_{3}\right): \delta=167.6\left(\mathrm{C}_{\mathrm{q}}\right), 147.5(\mathrm{CH}), 138.2\left(\mathrm{C}_{\mathrm{q}}\right), 138.0\left(\mathrm{C}_{\mathrm{q}}\right), 137.8\left(\mathrm{C}_{\mathrm{q}}\right), 137.7$ $\left(\mathrm{C}_{\mathrm{q}}\right), 136.2\left(\mathrm{C}_{\mathrm{q}}\right), 135.8(\mathrm{CH}), 134.1\left(\mathrm{C}_{\mathrm{q}}\right), 133.5\left(\mathrm{C}_{\mathrm{q}}\right), 132.2\left(\mathrm{C}_{\mathrm{q}}\right), 129.8(\mathrm{CH}), 128.8(\mathrm{CH}), 128.6(\mathrm{CH})$, $128.0(\mathrm{CH}), 127.7(\mathrm{CH}), 127.5\left(\mathrm{C}_{\mathrm{q}}\right), 127.1(\mathrm{CH}), 127.0(\mathrm{CH}), 126.3(\mathrm{CH}), 126.0(\mathrm{CH}), 125.6(\mathrm{CH})$, $124.9(\mathrm{CH}), 121.3(\mathrm{CH}), 121.1(\mathrm{CH}), 116.0(\mathrm{CH}), 19.9\left(\mathrm{CH}_{3}\right)$.

IR (ATR): 1674, 1521, 1479, 1261, 798, $609 \mathrm{~cm}^{-1}$.

MS (EI) $m / z$ (relative intensity): 388 (35) [M] $]^{+}, 245$ (100), 202 (35).

HR-MS (EI) $m / z$ calcd for $\mathrm{C}_{27} \mathrm{H}_{20} \mathrm{~N}_{2} \mathrm{O}^{+}[\mathrm{M}]^{+}: 388.1576$, found: 388.1579 . 


\section{H/D-Exchange Experiment}
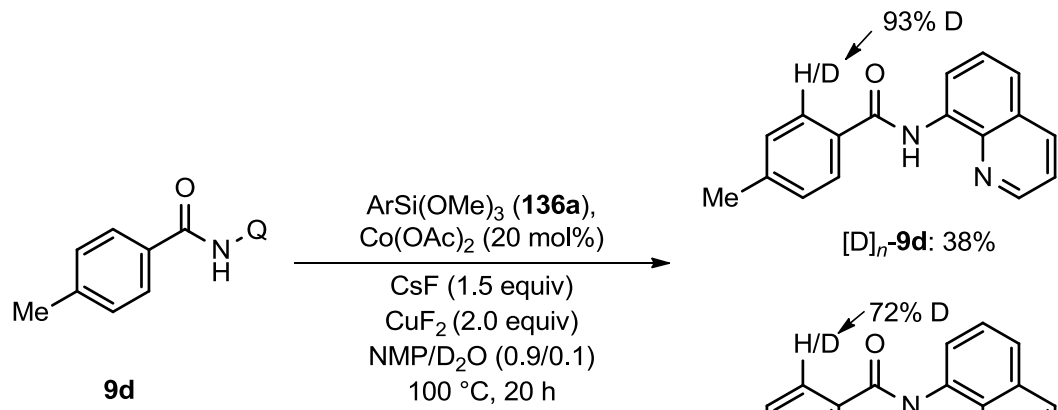

$[D]_{n}-9 d: 38 \%$

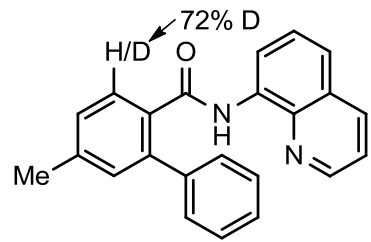

$[\mathrm{D}]_{n}-137 \mathrm{da}: 43 \%$

The representative procedure $\mathbf{D}$ was followed using 9d $(65.5 \mathrm{mg}, 0.25 \mathrm{mmol}, 1.0$ equiv), 136a (37.1 $\mathrm{mg}, 0.375 \mathrm{mmol}, 1.5$ equiv), $\mathrm{Co}(\mathrm{OAc})_{2}(8.9 \mathrm{mg}, 20 \mathrm{~mol} \%), \mathrm{CsF}$ (114 mg, $0.75 \mathrm{mmol}, 3.0$ equiv) and $\mathrm{CuF}_{2}\left(51.0 \mathrm{mg}, 0.5 \mathrm{mmol}, 2.0\right.$ equiv) in $\mathrm{NMP}(0.9 \mathrm{~mL})$ and $\mathrm{D}_{2} \mathrm{O}(0.1 \mathrm{~mL})$. At ambient temperature, the reaction mixture was diluted with $\mathrm{CH}_{2} \mathrm{Cl}_{2}(15 \mathrm{~mL})$ and washed with $\mathrm{NaOH}(2 \mathrm{M}, 10 \mathrm{~mL})$ and $\mathrm{H}_{2} \mathrm{O}(2 \mathrm{x}$ $20 \mathrm{~mL}$ ). The combined organic layers were dried over $\mathrm{Na}_{2} \mathrm{SO}_{4}$. After filtration and evaporation of the solvents in vacuo, the remaining residue was purified by column chromatography on silica gel ( $n$-hexane/Aceton) to yield $[\mathrm{D}]_{\mathrm{n}}-\mathbf{9 d}\left(25.1 \mathrm{mg}, 38 \%\right.$, ) and $[\mathrm{D}]_{\mathrm{n}}-\mathbf{1 3 7 d a}(36.6 \mathrm{mg}, 43 \%)$ as white solids. 


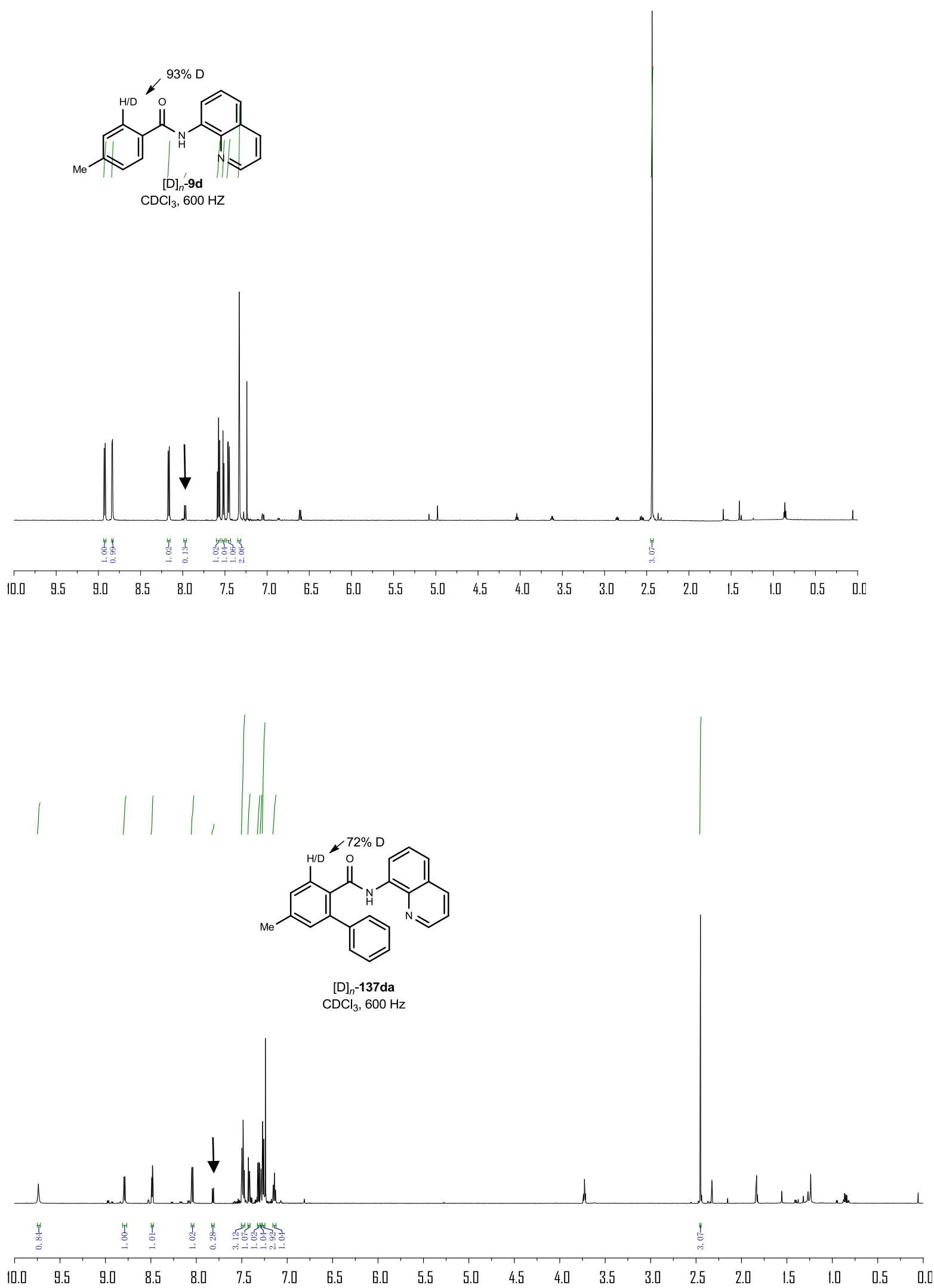




\subsubsection{Cobalt-Catalyzed C-H/C-C Functionalizations}

\section{Analytical Data}

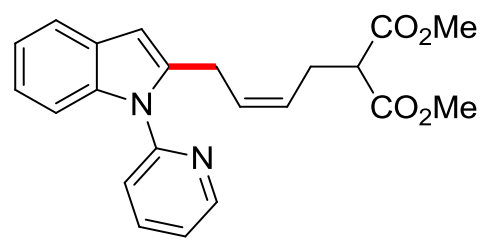

\section{(Z)-Dimethyl 2-\{4-[1-(pyridin-2-yl)-1H-indol-2-yl]but-2-en-1-yl\}malonate [(Z)-151aa]:}

The general procedure $\mathbf{F}$ was followed using 1-(pyridin-2-yl)-1 $H$-indole (95a) $(97.1 \mathrm{mg}, 0.50 \mathrm{mmol})$ and dimethyl 2-vinylcyclopropane-1,1-dicarboxylate (138a) (110 mg, $0.60 \mathrm{mmol})$. Isolation by column chromatography ( $n$-hexane/EtOAc: $3 / 1)$ yielded $(Z)-\mathbf{1 5 1 a a}(176 \mathrm{mg}, 93 \%, E / Z=1: 11)$ as a yellow oil.

${ }^{1}$ H-NMR $\left(300 \mathrm{MHz}, \mathrm{CDCl}_{3}\right): \delta=8.64(\mathrm{ddd}, J=4.9,1.9,0.8 \mathrm{~Hz}, 1 \mathrm{H}), 7.86(\mathrm{ddd}, J=8.0,7.6,1.9 \mathrm{~Hz}$, 1H), 7.59-7.53 (m, 1H), 7.46-7.41 (m, 1H), 7.36-7.27 (m, 2H), 7.15-7.09 (m, 2H), $6.43(\mathrm{~d}, J=$ $0.7 \mathrm{~Hz}, 1 \mathrm{H}), 5.64(\mathrm{dtt}, J=10.8,7.2,1.0 \mathrm{~Hz}, 1 \mathrm{H}), 5.40$ (dtt, $J=10.8,7.6,1.0 \mathrm{~Hz}, 1 \mathrm{H}), 3.69$ (s, 6H), $3.65(\mathrm{~d}, J=7.2 \mathrm{~Hz}, 2 \mathrm{H}), 3.35(\mathrm{t}, J=7.7 \mathrm{~Hz}, 1 \mathrm{H}), 2.62(\mathrm{ddd}, J=7.7,7.6,1.0 \mathrm{~Hz}, 1.83 \mathrm{H}, Z), 2.54$ (ddd, $J=7.7,7.6,1.0 \mathrm{~Hz}, 0.17 \mathrm{H}, E)$.

${ }^{13}$ C-NMR $\left(125 \mathrm{MHz}, \mathrm{CDCl}_{3}\right): \delta=169.0\left(\mathrm{C}_{\mathrm{q}}\right), 151.1\left(\mathrm{C}_{\mathrm{q}}\right), 149.5(\mathrm{CH}), 139.2\left(\mathrm{C}_{\mathrm{q}}\right), 138.1(\mathrm{CH})$, $137.2\left(\mathrm{C}_{\mathrm{q}}\right), 128.8(\mathrm{CH}), 128.4\left(\mathrm{C}_{\mathrm{q}}\right), 126.2(\mathrm{CH}), 121.9(\mathrm{CH}), 121.7(\mathrm{CH}), 120.8(\mathrm{CH}), 120.5(\mathrm{CH})$, $119.9(\mathrm{CH}), 109.9(\mathrm{CH}), 102.7(\mathrm{CH}), 52.5\left(\mathrm{CH}_{3}\right), 51.5(\mathrm{CH}), 31.7\left(\mathrm{CH}_{2}, E\right), 30.9\left(\mathrm{CH}_{2}, E\right), 26.7\left(\mathrm{CH}_{2}\right.$, $\mathrm{Z}), 25.9\left(\mathrm{CH}_{2}, \mathrm{Z}\right)$.

IR (ATR): 1732, 1586, 1469, 1436, 1150, $745 \mathrm{~cm}^{-1}$.

MS (EI) $m / z$ (relative intensity): 378 (30) [M] ${ }^{+}, 247$ (100), 219 (90), 206 (70).

HR-MS (EI): $m / z$ calcd. for $\left[\mathrm{C}_{22} \mathrm{H}_{22} \mathrm{~N}_{2} \mathrm{O}_{4}\right]^{+}[\mathrm{M}]^{+} \quad 378.1574$, found 378.1578. 


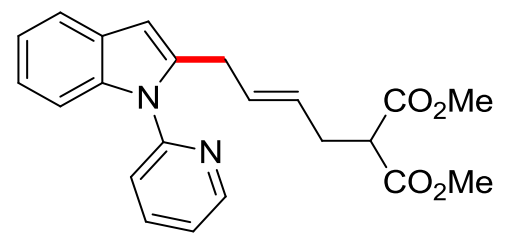

\section{(E)-Dimethyl 2-\{4-[1-(pyridin-2-yl)-1H-indol-2-yl]but-2-en-1-yl\}malonate [(E)-151aa']:}

The general procedure $\mathbf{G}$ was followed using 1-(pyridin-2-yl)-1 $H$-indole (95a) (48.5 mg, $0.25 \mathrm{mmol})$ and dimethyl 2-vinylcyclopropane-1,1-dicarboxylate (138a) (55.2 $\mathrm{mg}, 0.30 \mathrm{mmol}$ ). Isolation by column chromatography ( $n$-hexane/EtOAc: $3 / 1)$ yielded $(E)-151 a a^{\prime}(72.8 \mathrm{mg}, 77 \%, E / Z=2: 1)$ as a yellow oil.

${ }^{1}$ H-NMR $\left(300 \mathrm{MHz}, \mathrm{CDCl}_{3}\right): \delta=8.65-8.60(\mathrm{~m}, 1 \mathrm{H}), 7.85$ (ddd, $\left.J=8.0,7.6,2.0 \mathrm{~Hz}, 1 \mathrm{H}\right), 7.55$ (dd, $J$ $=5.9,3.2 \mathrm{~Hz}, 1 \mathrm{H}), 7.46-7.38(\mathrm{~m}, 1 \mathrm{H}), 7.35-7.26(\mathrm{~m}, 2 \mathrm{H}), 7.14-7.08(\mathrm{~m}, 2 \mathrm{H}), 6.41(\mathrm{~d}, J=0.7 \mathrm{~Hz}$, 1H), 5.69-5.56 (m, 1H), $5.40(\mathrm{dtt}, J=10.8,7.6,1.0 \mathrm{~Hz}, 0.33 \mathrm{H}, Z), 5.32(\mathrm{dtt}, J=15.7,7.6,1.0 \mathrm{~Hz}$, $0.67 \mathrm{H}, E), 3.69$ (s, 6H), 3.55 (d, $J=6.6 \mathrm{~Hz}, 2 \mathrm{H}), 3.33$ (t, $J=7.7 \mathrm{~Hz}, 1 \mathrm{H}), 2.62$ (ddd, $J=7.7,7.6$, $1.4 \mathrm{~Hz}, 0.73 \mathrm{H}, Z), 2.53(\mathrm{ddd}, J=7.7,7.6,1.4 \mathrm{~Hz}, 1.27 \mathrm{H}, E)$.

${ }^{13}$ C-NMR (125 MHz, $\left.\mathrm{CDCl}_{3}\right): \delta=169.0\left(\mathrm{C}_{\mathrm{q}}\right), 151.1\left(\mathrm{C}_{\mathrm{q}}\right), 149.3(\mathrm{CH}), 139.1\left(\mathrm{C}_{\mathrm{q}}\right), 138.0(\mathrm{CH}), 137.1$ $\left(\mathrm{C}_{\mathrm{q}}\right), 129.6(\mathrm{CH}), 127.5\left(\mathrm{C}_{\mathrm{q}}\right), 126.2(\mathrm{CH}), 121.8(\mathrm{CH}), 121.7(\mathrm{CH}), 120.8(\mathrm{CH}), 120.5(\mathrm{CH}), 119.9$ $(\mathrm{CH}), 110.0(\mathrm{CH}), 102.9(\mathrm{CH}), 52.4\left(\mathrm{CH}_{3}\right), 51.6(\mathrm{CH}), 31.7\left(\mathrm{CH}_{2}, E\right), 30.9\left(\mathrm{CH}_{2}, E\right), 26.7\left(\mathrm{CH}_{2}, \mathrm{Z}\right)$, $25.9\left(\mathrm{CH}_{2}, \mathrm{Z}\right)$.

IR (ATR): 1732, 1586, 1469, 1436, 1150, $745 \mathrm{~cm}^{-1}$.

MS (EI) $m / z$ (relative intensity): 378 (30) [M] ${ }^{+}, 247$ (100), 219 (90), 206 (70).

HR-MS (EI): $m / z$ calcd. for $\left[\mathrm{C}_{22} \mathrm{H}_{22} \mathrm{~N}_{2} \mathrm{O}_{4}\right]^{+}[\mathrm{M}]^{+} \quad 378.1574$, found 378.1578. 


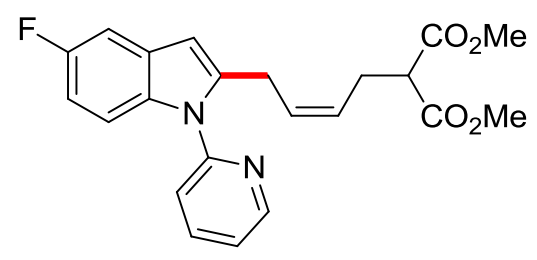

(Z)-Dimethyl 2-\{4-[5-fluoro-1-(pyridin-2-yl)-1H-indol-2-yl]but-2-en-1-yl\}malonate [(Z)-151ba]:

The general procedure $\mathbf{F}$ was followed using 5-fluoro-1-(pyridin-2-yl)-1H-indole (95b) (106 mg, $0.50 \mathrm{mmol}$ ) and dimethyl 2-vinylcyclopropane-1,1-dicarboxylate (138a) (110 mg, $0.60 \mathrm{mmol}$ ). Isolation by column chromatography ( $n$-hexane/EtOAc: $3 / 1)$ yielded $(Z)$-151ba $(182 \mathrm{mg}, 92 \%, E / Z=$ 1:10) as a yellow oil.

${ }^{1}$ H-NMR $\left(300 \mathrm{MHz}, \mathrm{CDCl}_{3}\right): \delta=8.66(\mathrm{ddd}, J=4.9,2.0,0.8 \mathrm{~Hz}, 1 \mathrm{H}), 7.90(\mathrm{ddd}, J=8.0,7.5,2.0 \mathrm{~Hz}$, 1H), 7.42 (dt, $J=8.0,2.0 \mathrm{~Hz}, 1 \mathrm{H}), 7.36-7.30(\mathrm{~m}, 1 \mathrm{H}), 7.23-7.15(\mathrm{~m}, 2 \mathrm{H}), 6.85(\mathrm{td}, J=9.1,2.6 \mathrm{~Hz}$, $1 \mathrm{H}), 6.38(\mathrm{~d}, J=0.8 \mathrm{~Hz}, 1 \mathrm{H}), 5.60(\mathrm{dtt}, J=10.8,7.4,1.4 \mathrm{~Hz}, 1 \mathrm{H}), 5.39$ (dtt, $J=10.8,7.6,1.0 \mathrm{~Hz}$, $1 \mathrm{H}), 3.68(\mathrm{~s}, 6 \mathrm{H}), 3.61(\mathrm{~d}, J=7.4 \mathrm{~Hz}, 2 \mathrm{H}), 3.36(\mathrm{t}, J=7.6,1 \mathrm{H}), 2.59$ (ddd, $J=7.6,7.6,1.4 \mathrm{~Hz}$, $1.82 \mathrm{H}, Z$ ), 2.53 (ddd, $J=7.6,7.6,1.4 \mathrm{~Hz}, 0.18 \mathrm{H}, E$ ).

${ }^{13}$ C-NMR $\left(125 \mathrm{MHz}, \mathrm{CDCl}_{3}\right): \delta=169.1\left(\mathrm{C}_{\mathrm{q}}\right), 158.3\left(\mathrm{C}_{\mathrm{q}},{ }^{1} J_{\mathrm{C}-\mathrm{F}}=234.0 \mathrm{~Hz}\right), 151.0\left(\mathrm{C}_{\mathrm{q}}\right), 149.6(\mathrm{CH})$, $140.8\left(\mathrm{C}_{\mathrm{q}}\right), 138.3(\mathrm{CH}), 133.8\left(\mathrm{C}_{\mathrm{q}}\right), 128.8\left(\mathrm{C}_{\mathrm{q}},{ }^{3} J_{\mathrm{C}-\mathrm{F}}=10.3 \mathrm{~Hz}\right), 128.5(\mathrm{CH}), 126.5(\mathrm{CH}), 122.1(\mathrm{CH})$, $120.8(\mathrm{CH}), 110.7\left(\mathrm{CH},{ }^{3} J_{\mathrm{C}-\mathrm{F}}=9.7 \mathrm{~Hz}\right), 109.7\left(\mathrm{CH},{ }^{2} J_{\mathrm{C}-\mathrm{F}}=25.9 \mathrm{~Hz}\right), 104.9\left(\mathrm{CH},{ }^{2} J_{\mathrm{C}-\mathrm{F}}=23.6 \mathrm{~Hz}\right)$, $102.6\left(\mathrm{CH},{ }^{4} J_{\mathrm{C}-\mathrm{F}}=4.5 \mathrm{~Hz}\right), 52.5\left(\mathrm{CH}_{3}\right), 51.5(\mathrm{CH}), 31.7\left(\mathrm{CH}_{2}, E\right), 31.0\left(\mathrm{CH}_{2}, E\right), 26.7\left(\mathrm{CH}_{2}, Z\right), 26.0$ $\left(\mathrm{CH}_{2}, \mathrm{Z}\right)$.

${ }^{19}$ F-NMR $\left(282 \mathrm{MHz}, \mathrm{CDCl}_{3}\right): \delta=-123.9(E),-124.0(Z)$.

IR (ATR): 1732, 1585, 1470, 1436, 1265, 1230, 1151, 730, $701 \mathrm{~cm}^{-1}$.

MS (ESI) $m / z$ (relative intensity): $419(80)[\mathrm{M}+\mathrm{Na}]^{+}, 397(100)[\mathrm{M}+\mathrm{H}]^{+}$.

HR-MS (ESI) $m / z$ calcd. for $\mathrm{C}_{22} \mathrm{H}_{22} \mathrm{FN}_{2} \mathrm{O}_{4}{ }^{+}[\mathrm{M}+\mathrm{H}]^{+} 397.1558$, found 397.1557 . 


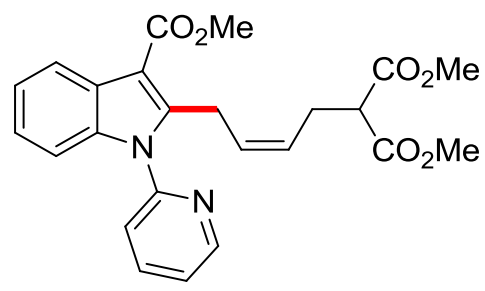

(Z)-Dimethyl 2-\{4-[6-(methoxycarbonyl)-1-(pyridin-2-yl)-1H-indol-2-yl]but-2-en-1-yl\}malonate [(Z)-151ca]:

The general procedure $\mathbf{F}$ was followed using 3-methoxycabonyl-1-(pyridin-2-yl)-1 $H$-indole (95c) (126 mg, $0.50 \mathrm{mmol})$ and dimethyl 2-vinylcyclopropane-1,1-dicarboxylate (138a) (110 mg, $0.60 \mathrm{mmol}$ ). Isolation by column chromatography ( $n$-hexane/EtOAc: $3 / 1)$ yielded $(Z)$-151ca (153 mg, $70 \%, E / Z=1: 25)$ as a yellow oil.

${ }^{1}$ H-NMR $\left(500 \mathrm{MHz}, \mathrm{CDCl}_{3}\right): \delta=8.71-8.66(\mathrm{~m}, 1 \mathrm{H}), 8.18-8.14(\mathrm{~m}, 1 \mathrm{H}), 7.92(\mathrm{td}, J=7.7,2.0 \mathrm{~Hz}, 1 \mathrm{H})$, 7.44-7.36 (m, 2H), 7.24 (ddd, $J=8.0,6.2,2.0 \mathrm{~Hz}, 1 \mathrm{H}) .7 .19-7.11(\mathrm{~m}, 2 \mathrm{H}), 5.40$ (dtt, $J=10.8,7.6$, $0.8 \mathrm{~Hz}, 1 \mathrm{H}), 5.16(\mathrm{dtt}, J=10.8,7.5,1.2 \mathrm{~Hz}, 1 \mathrm{H}), 4.06(\mathrm{dd}, J=6.8,1.4 \mathrm{~Hz}, 2 \mathrm{H}), 3.94(\mathrm{~s}, 3 \mathrm{H}), 3.69$ (s, $5.78 \mathrm{H}, Z), 3.61(\mathrm{~s}, 0.22 \mathrm{H}, E), 3.24(\mathrm{t}, J=7.6 \mathrm{~Hz}, 1 \mathrm{H}), 2.37(\mathrm{ddd}, J=7.6,7.5,0.8 \mathrm{~Hz}, 2 \mathrm{H})$.

${ }^{13}$ C-NMR (125 MHz, $\left.\mathrm{CDCl}_{3}\right): \delta=169.0\left(\mathrm{C}_{\mathrm{q}}\right), 165.8\left(\mathrm{C}_{\mathrm{q}}\right), 150.0\left(\mathrm{C}_{\mathrm{q}}\right), 149.9(\mathrm{CH}), 146.5(\mathrm{CH}), 138.6$ $\left(\mathrm{C}_{\mathrm{q}}\right), 136.7(\mathrm{CH}), 128.7(\mathrm{CH}), 128.5\left(\mathrm{C}_{\mathrm{q}}\right), 126.4(\mathrm{CH}), 125.7\left(\mathrm{C}_{\mathrm{q}}\right), 123.4(\mathrm{CH}), 122.9(\mathrm{CH}), 122.3(\mathrm{CH})$, $121.6\left(\mathrm{C}_{\mathrm{q}}\right), 110.2(\mathrm{CH}), 105.8(\mathrm{CH}), 52.4(\mathrm{CH}), 51.2\left(\mathrm{CH}_{3}\right), 50.9\left(\mathrm{CH}_{3}\right), 26.6\left(\mathrm{CH}_{2}\right), 24.6\left(\mathrm{CH}_{2}\right)$.

IR (ATR): 1735, 1698, 1588, 1538, 1469, 1436, 1194, 788, $749 \mathrm{~cm}^{-1}$.

MS (ESI) $m / z$ (relative intensity): $459(100)[\mathrm{M}+\mathrm{Na}]^{+}, 437(100)[\mathrm{M}+\mathrm{H}]^{+}$.

HR-MS (ESI) $m / z$ calcd. for $\mathrm{C}_{24} \mathrm{H}_{25} \mathrm{~N}_{2} \mathrm{O}_{6}{ }^{+}[\mathrm{M}+\mathrm{H}]^{+} 437.1707$, found 437.1709. 


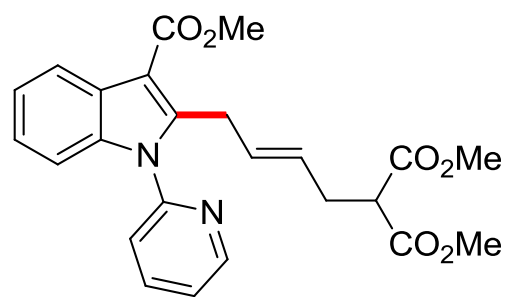

(E,Z)-Dimethyl 2-\{4-[6-(methoxycarbonyl)-1-(pyridin-2-yl)-1H-indol-2-yl]but-2-en-1-yl\}-malonate $[(E, Z)-151 \mathrm{ca}]$ :

The general procedure $\mathbf{G}$ was followed using 3-methoxycabonyl-1-(pyridin-2-yl)-1H-indole (95c) $(63.0 \mathrm{mg}, \quad 0.25 \mathrm{mmol})$ and dimethyl 2-vinylcyclopropane-1,1-dicarboxylate (138a) (55.2 $\mathrm{mg}$, $0.30 \mathrm{mmol})$. Isolation by column chromatography ( -hexane/EtOAc: $3 / 1)$ yielded $(E, Z)-151 \mathbf{c a}^{\prime}$ $(104 \mathrm{mg}, 95 \%, E / Z=1: 1)$ as a yellow oil.

${ }^{1}$ H-NMR $\left(500 \mathrm{MHz}, \mathrm{CDCl}_{3}\right): \delta=8.72-8.67(\mathrm{~m}, 1 \mathrm{H}), 8.19-8.13(\mathrm{~m}, 1 \mathrm{H}), 7.96-7.89(\mathrm{~m}, 1 \mathrm{H}), 7.43-$ 7.37 (m, 2H), 7.27-7.22 (m, 1H), 7.19-7.12 (m, 2H), 5.53 (dtt, $J=15.4,7.5,1.4 \mathrm{~Hz}, 0.50 \mathrm{H}, E), 5.40$ $(\mathrm{dtt}, J=10.7,7.5,1.4 \mathrm{~Hz}, 0.50 \mathrm{H}, Z), 5.19(\mathrm{dtt}, J=10.7,7.5,1.1 \mathrm{~Hz}, 0.50 \mathrm{H}, Z), 5.09$ (dtt, $J=15.4,7.5$, $1.1 \mathrm{~Hz}, 0.50 \mathrm{H}, E), 4.06$ (d, J=7.0 Hz, 0.96H, E), 3.95 (s, 3H), 3.93 (d, J = 7.0 Hz, 1.04H, Z), 3.69 (s, $3.17 \mathrm{H}, Z), 3.62(\mathrm{~s}, 2.83 \mathrm{H}, E), 3.23-3.21(\mathrm{~m}, 1 \mathrm{H}), 2.42$ (d, $J=7.6,7.5,1.4 \mathrm{~Hz}, 0.94 \mathrm{H}, E), 2.37$ (ddd, $J$ $=7.6,7.5,1.4 \mathrm{~Hz}, 1.06 \mathrm{H}, Z)$.

${ }^{13}$ C-NMR (125 MHz, $\left.\mathrm{CDCl}_{3}\right): \delta=169.3\left(\mathrm{C}_{\mathrm{q}}\right), 166.1\left(\mathrm{C}_{\mathrm{q}}\right), 150.2\left(\mathrm{C}_{\mathrm{q}}\right), 146.7\left(\mathrm{C}_{\mathrm{q}}\right), 138.8(\mathrm{CH}), 136.8$ $\left(\mathrm{C}_{\mathrm{q}}\right), 129.3(\mathrm{CH}), 128.7(\mathrm{CH}), 127.2(\mathrm{CH}), 126.6\left(\mathrm{C}_{\mathrm{q}}\right), 125.8(\mathrm{CH}), 123.6(\mathrm{CH}), 123.1(\mathrm{CH}), 122.5$ $(\mathrm{CH}), 121.7(\mathrm{CH}), 110.4(\mathrm{CH}), 106.0\left(\mathrm{C}_{\mathrm{q}}\right), 52.6\left(\mathrm{CH}_{3}\right), 51.3(\mathrm{CH}), 51.0\left(\mathrm{CH}_{3}\right), 31.6\left(\mathrm{CH}_{2}, E\right), 29.1$ $\left(\mathrm{CH}_{2}, E\right), 26.6\left(\mathrm{CH}_{2}, \mathrm{Z}\right), 24.6\left(\mathrm{CH}_{2}, \mathrm{Z}\right)$.

IR (ATR): 1732, 1695, 1587, 1468, 1434, 1190, 1152, 1077, 788, $732 \mathrm{~cm}^{-1}$.

MS (ESI) $m / z$ (relative intensity): $459(100)[\mathrm{M}+\mathrm{Na}]^{+}, 437(100)[\mathrm{M}+\mathrm{H}]^{+}$.

HR-MS (ESI) $m / z$ calcd. for $\mathrm{C}_{24} \mathrm{H}_{24} \mathrm{~N}_{2} \mathrm{NaO}_{6}{ }^{+}\left[\mathrm{M}+\mathrm{Na}^{+}\right]$459.1527, found 459.1527 . 


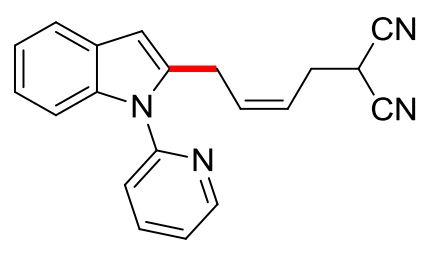

\section{(Z)-2-\{4-[1-(Pyridin-2-yl)-1H-indol-2-yl]but-2-en-1-yl\}malonitrile [(Z)-151ab]:}

The general procedure $\mathbf{F}$ was followed using 1-(pyridin-2-yl)-1H-indole (95a) $(97.1 \mathrm{mg}, 0.50 \mathrm{mmol})$ and 2-vinylcyclopropane-1,1-dicarbonitrile (138b) $(70.9 \mathrm{mg}, 0.60 \mathrm{mmol})$. Isolation by column chromatography ( $n$-hexane/EtOAc: $3 / 1)$ yielded $(Z)$-151ab $(105 \mathrm{mg}, 67 \%, E / Z=1: 3)$ as a pale yellow oil.

${ }^{1}$ H-NMR $\left(600 \mathrm{MHz}, \mathrm{CDCl}_{3}\right): \delta=8.66-8.63(\mathrm{~m}, 1 \mathrm{H}), 7.90(\mathrm{ddd}, J=7.9,4.9,2.0 \mathrm{~Hz}, 1 \mathrm{H}), 7.58-7.54$ (m, 1H), $7.46(\mathrm{~d}, J=7.9 \mathrm{~Hz}, 1 \mathrm{H}), 7.36-7.30(\mathrm{~m}, 2 \mathrm{H}), 7.16-7.11(\mathrm{~m}, 2 \mathrm{H}), 6.44(\mathrm{~d}, J=0.7 \mathrm{~Hz}, 1 \mathrm{H})$, 5.98-5.88 (m, 1H), $5.50(\mathrm{dtt}, J=10.4,7.5,1.1 \mathrm{~Hz}, 0.77 \mathrm{H}, Z), 5.37(\mathrm{dtt}, J=15.4,7.5,1.0 \mathrm{~Hz}, 0.23 \mathrm{H}$, $E), 3.70(\mathrm{~d}, J=7.5 \mathrm{~Hz}, 2 \mathrm{H}), 3.60(\mathrm{t}, J=7.2 \mathrm{~Hz}, 0.77 \mathrm{H}, Z), 3.60(\mathrm{t}, J=7.2 \mathrm{~Hz}, 0.23 \mathrm{H}, E), 2.71(\mathrm{ddd}, J$ $=7.3,7.2,1.1 \mathrm{~Hz}, 2 \mathrm{H})$.

${ }^{13}$ C-NMR (125 MHz, $\left.\mathrm{CDCl}_{3}\right): \delta=151.1\left(\mathrm{C}_{\mathrm{q}}\right), 149.6(\mathrm{CH}), 138.4(\mathrm{CH}), 137.9\left(\mathrm{C}_{\mathrm{q}}\right), 137.2\left(\mathrm{C}_{\mathrm{q}}\right), 135.0$ $(\mathrm{CH}), 133.2(\mathrm{CH}), 128.3\left(\mathrm{C}_{\mathrm{q}}\right), 122.6(\mathrm{CH}), 122.1(\mathrm{CH}), 122.0(\mathrm{CH}), 120.9(\mathrm{CH}), 120.2(\mathrm{CH}), 112.1$ $\left(\mathrm{C}_{\mathrm{q}}\right), 110.0(\mathrm{CH}), 103.2(\mathrm{CH}), 33.8\left(\mathrm{CH}_{2}, E\right), 30.9\left(\mathrm{CH}_{2}, E\right), 28.6\left(\mathrm{CH}_{2}, \mathrm{Z}\right), 26.3\left(\mathrm{CH}_{2}, \mathrm{Z}\right), 22.8(\mathrm{CH})$. IR (ATR): 2257, 1586, 1469, 1456, 1437, 1211, 1149, 782, $745 \mathrm{~cm}^{-1}$.

MS (ESI) $m / z$ (relative intensity): 335 (100) $[\mathrm{M}+\mathrm{Na}]^{+}, 313(80)[\mathrm{M}+\mathrm{H}]^{+}, 197(80)$.

HR-MS (ESI) $m / z$ calcd. for $\mathrm{C}_{20} \mathrm{H}_{17} \mathrm{~N}_{4}{ }^{+}[\mathrm{M}+\mathrm{H}]^{+} 313.1448$, found 313.1442 .

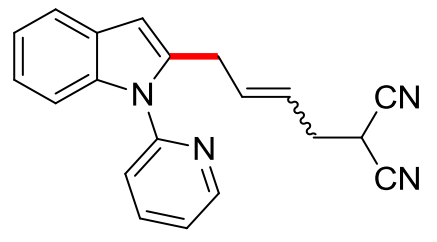

(E,Z)-2-\{4-[1-(Pyridin-2-yl)-1H-indol-2-yl]but-2-en-1-yl\}malonitrile [(E,Z)-151ab']:

The general procedure $\mathbf{G}$ was followed using 1-(pyridin-2-yl)-1 $H$-indole (95a) (48.5 mg, $0.25 \mathrm{mmol})$ and 2-vinylcyclopropane-1,1-dicarbonitrile (138b) $(35.5 \mathrm{mg}, 0.30 \mathrm{mmol})$. Isolation by column 
chromatography (n-hexane/EtOAc: 3/1) yielded (E,Z)-151ab' $(54.2 \mathrm{mg}, 69 \%, E / Z=1: 1)$ as a pale yellow oil.

${ }^{1}$ H-NMR $\left(500 \mathrm{MHz}, \mathrm{CDCl}_{3}\right): \delta=8.68-8.64(\mathrm{~m}, 1 \mathrm{H}), 7.92(\mathrm{ddd}, J=7.9,4.9,2.0 \mathrm{~Hz}, 1 \mathrm{H}), 7.58(\mathrm{dd}, J$ $=8.1,3.9 \mathrm{~Hz}, 1 \mathrm{H}), 7.48(\mathrm{dt}, J=8.0,1.0 \mathrm{~Hz}, 1 \mathrm{H}), 7.37-7.32(\mathrm{~m}, 2 \mathrm{H}), 7.18-7.14(\mathrm{~m}, 2 \mathrm{H}), 6.49(\mathrm{~d}, 0.7$ $\mathrm{Hz}, 0.47 \mathrm{H}, E), 6.46(\mathrm{~d}, 0.7 \mathrm{~Hz}, 0.53 \mathrm{H}, Z), 5.98-5.88(\mathrm{~m}, 1 \mathrm{H}), 5.50(\mathrm{dtt}, J=10.4,7.5,1.1 \mathrm{~Hz}, 0.47 \mathrm{H}$, $Z$ ), $5.37(\mathrm{dtt}, J=15.4,7.5,1.0 \mathrm{~Hz}, 0.53 \mathrm{H}, E), 3.72(\mathrm{~d}, J=7.6 \mathrm{~Hz}, 2 \mathrm{H}), 3.67(\mathrm{t}, J=7.5 \mathrm{~Hz}, 0.53 \mathrm{H}, Z$ ), $3.58(\mathrm{t}, J=7.5 \mathrm{~Hz}, 0.47 \mathrm{H}, E), 2.73(\mathrm{ddd}, J=7.5,7.4,1.1 \mathrm{~Hz}, 1.06 \mathrm{H}), 2.62(\mathrm{ddd}, J=7.5,7.4,1.1 \mathrm{~Hz}$, $0.94 \mathrm{H})$.

${ }^{13}$ C-NMR $\left(125 \mathrm{MHz}, \mathrm{CDCl}_{3}\right): \delta=151.1\left(\mathrm{C}_{\mathrm{q}}\right), 149.7(\mathrm{CH}), 138.5(\mathrm{CH}), 138.0\left(\mathrm{C}_{\mathrm{q}}\right), 137.2\left(\mathrm{C}_{\mathrm{q}}\right), 135.1$ $(\mathrm{CH}), 133.3(\mathrm{CH}), 128.3\left(\mathrm{C}_{\mathrm{q}}\right), 122.6(\mathrm{CH}), 122.2(\mathrm{CH}), 120.9(\mathrm{CH}), 120.3(\mathrm{CH}), 112.2\left(\mathrm{C}_{\mathrm{q}}\right), 110.0$ $(\mathrm{CH}), 103.5(\mathrm{CH}), 103.2(\mathrm{CH}), 33.7\left(\mathrm{CH}_{2}, E\right), 30.9\left(\mathrm{CH}_{2}, E\right), 28.5\left(\mathrm{CH}_{2}, \mathrm{Z}\right), 26.2\left(\mathrm{CH}_{2}, \mathrm{Z}\right), 23.7(\mathrm{CH}$, E), $22.1(\mathrm{CH}, Z)$.

IR (ATR): 2257, 1586, 1468, 1455, 1436, 1211, 908, 738, $737 \mathrm{~cm}^{-1}$.

MS (ESI) $m / z$ (relative intensity): $335(100)[\mathrm{M}+\mathrm{Na}]^{+}, 313(80)[\mathrm{M}+\mathrm{H}]^{+}, 197(80)$.

HR-MS (ESI) $m / z$ calcd. for $\mathrm{C}_{20} \mathrm{H}_{16} \mathrm{~N}_{4} \mathrm{Na}^{+}[\mathrm{M}+\mathrm{Na}]^{+} 335.1267$, found 335.1270 .

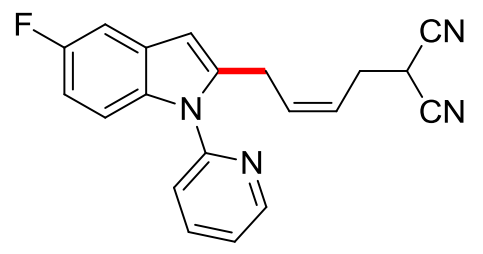

\section{(Z)-2-\{4-[5-Fluoro-1-(pyridin-2-yl)-1H-indol-2-yl]but-2-en-1-yl\}malonitrile [(Z)-151bb]:}

The general procedure $\mathbf{F}$ was followed using 5-fluoro-1-(pyridin-2-yl)-1H-indole (95b) (106 mg, $0.50 \mathrm{mmol}$ ) and 2-vinylcyclopropane-1,1-dicarbonitrile (138b) (70.9 $\mathrm{mg}, 0.60 \mathrm{mmol})$. Isolation by column chromatography ( $n$-hexane/EtOAc: $3 / 1)$ yielded $(Z)-151 b b(114 \mathrm{mg}, 69 \%, E / Z=1: 4)$ as a yellow oil.

${ }^{1}$ H-NMR $\left(600 \mathrm{MHz}, \mathrm{CDCl}_{3}\right): \delta=8.66-8.63(\mathrm{~m}, 1 \mathrm{H}), 7.91(\mathrm{ddd}, J=7.9,5.0,2.0 \mathrm{~Hz}, 1 \mathrm{H}), 7.43(\mathrm{~d}, J$ $=7.5 \mathrm{~Hz}, 1 \mathrm{H}), 7.37-7.30(\mathrm{~m}, 1 \mathrm{H}), 7.25-7.17(\mathrm{~m}, 2 \mathrm{H}), 6.91-6.82(\mathrm{~m}, 1 \mathrm{H}), 6.42(\mathrm{~s}, 0.20 \mathrm{H}, E), 6.40(\mathrm{~s}$, $0.80 \mathrm{H}, Z), 5.98-5.83(\mathrm{~m}, 1 \mathrm{H}), 5.53(\mathrm{dtt}, J=10.8,7.5,1.0 \mathrm{~Hz}, 0.80 \mathrm{H}, Z), 5.39$ (dtt, $J=15.4,7.5$, $1.0 \mathrm{~Hz}, 0.20 \mathrm{H}, E), 3.75-3.56(\mathrm{~m}, 2 \mathrm{H}), 3.63(\mathrm{t}, J=7.5 \mathrm{~Hz}, 0.80 \mathrm{H}, Z), 3.63(\mathrm{t}, J=7.5 \mathrm{~Hz}, 0.20 \mathrm{H}, E)$, $2.72(\mathrm{ddd}, J=7.5,7.4,1.0 \mathrm{~Hz}, 1.60 \mathrm{H}, Z), 2.62(\mathrm{ddd}, J=7.5,7.4,1.0 \mathrm{~Hz}, 0.40 \mathrm{H}, E)$. 
${ }^{13}$ C-NMR $\left(125 \mathrm{MHz}, \mathrm{CDCl}_{3}\right): \delta=158.4\left(\mathrm{C}_{\mathrm{q}},{ }^{1} J_{\mathrm{C}-\mathrm{F}}=235.5 \mathrm{~Hz}\right), 150.8\left(\mathrm{C}_{\mathrm{q}}\right), 149.6(\mathrm{CH}), 139.5\left(\mathrm{C}_{\mathrm{q}}\right)$, $138.6(\mathrm{CH}), 133.7\left(\mathrm{C}_{\mathrm{q}}\right), 132.9(\mathrm{CH}), 128.7\left(\mathrm{C}_{\mathrm{q}},{ }^{3} J_{\mathrm{C}-\mathrm{F}}=10.5 \mathrm{~Hz}\right), 122.4(\mathrm{CH}), 122.1(\mathrm{CH}), 120.8$ $(\mathrm{CH}), 112.1\left(\mathrm{C}_{\mathrm{q}}\right), 110.7\left(\mathrm{CH},{ }^{3} J_{\mathrm{C}-\mathrm{F}}=9.7 \mathrm{~Hz}\right), 110.1\left(\mathrm{CH},{ }^{2} J_{\mathrm{C}-\mathrm{F}}=26.4 \mathrm{~Hz}\right), 105.1\left(\mathrm{CH},{ }^{2} J_{\mathrm{C}-\mathrm{F}}=\right.$ $23.9 \mathrm{~Hz}), 103.1\left(\mathrm{CH},{ }^{4} J_{\mathrm{C}-\mathrm{F}}=4.6 \mathrm{~Hz}\right), 33.7\left(\mathrm{CH}_{2}, E\right), 31.0\left(\mathrm{CH}_{2}, E\right), 28.6\left(\mathrm{CH}_{2}, Z\right), 26.3\left(\mathrm{CH}_{2}, Z\right)$, $23.2(\mathrm{CH}, E), 22.8(\mathrm{CH}, \mathrm{Z})$.

${ }^{19} \mathbf{F}-\mathbf{N M R}\left(282 \mathrm{MHz}, \mathrm{CDCl}_{3}\right): \delta=-123.5$.

IR (ATR): 2255, 1617, 1470, 1438, 1385, 1175, 785, $735 \mathrm{~cm}^{-1}$.

MS (ESI) $m / z$ (relative intensity): $353(100)[\mathrm{M}+\mathrm{Na}]^{+}, 331(80)[\mathrm{M}+\mathrm{H}]^{+}, 215(100)$.

HR-MS (ESI) $m / z$ calcd. for $\mathrm{C}_{20} \mathrm{H}_{16} \mathrm{FN}_{4}{ }^{+}[\mathrm{M}+\mathrm{H}]^{+} 331.1354$, found 331.1342 .

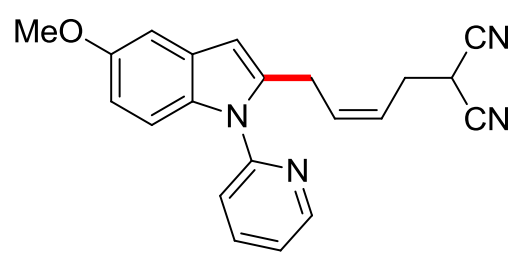

\section{(Z)-2-\{4-[5-Methoxy-1-(pyridin-2-yl)-1H-indol-2-yl]but-2-en-1-yl\}malonitrile [(Z)-151db]:}

The general procedure $\mathbf{F}$ was followed using 5-methoxy-1-(pyridin-2-yl)-1H-indole (95d) (112 mg, $0.50 \mathrm{mmol}$ ) and 2-vinylcyclopropane-1,1-dicarbonitrile (138b) (70.9 $\mathrm{mg}, 0.60 \mathrm{mmol})$. Isolation by column chromatography ( $n$-hexane/EtOAc: $3 / 1)$ yielded $(Z)-151 d b(118 \mathrm{mg}, 65 \%, E / Z=1: 3)$ as a pale yellow oil.

${ }^{1}$ H-NMR $\left(300 \mathrm{MHz}, \mathrm{CDCl}_{3}\right): \delta=8.63-8.60(\mathrm{~m}, 1 \mathrm{H}), 7.87(\mathrm{ddd}, J=7.9,5.0,2.0 \mathrm{~Hz}, 1 \mathrm{H}), 7.43(\mathrm{~d}, J=$ $7.9 \mathrm{~Hz}, 1 \mathrm{H}), 7.32-7.26(\mathrm{~m}, 2 \mathrm{H}), 7.03(\mathrm{~d}, J=2.5 \mathrm{~Hz}, 1 \mathrm{H}), 6.78(\mathrm{dd}, J=8.9,2.5 \mathrm{~Hz}, 1 \mathrm{H}), 6.39(\mathrm{~s}, 0.23 \mathrm{H}$, Z), $6.37(\mathrm{~s}, 0.77 \mathrm{H}, E), 5.91-5.84(\mathrm{~m}, 1 \mathrm{H}), 5.49(\mathrm{dtt}, J=10.8,7.5,1.1 \mathrm{~Hz}, 0.23 \mathrm{H}, Z), 5.34(\mathrm{dtt}, J=15.4$, $7.5,1.1 \mathrm{~Hz}, 0.77 \mathrm{H}, E), 3.83(\mathrm{~s}, 3 \mathrm{H}), 3.72-3.68(\mathrm{~m}, 2 \mathrm{H}), 3.63(\mathrm{t}, J=7.5 \mathrm{~Hz}, 1 \mathrm{H}), 2.69$ (ddd, $J=7.5$, 7.5, $1.1 \mathrm{~Hz}, 1.54 \mathrm{H}, Z), 2.57(\mathrm{ddd}, J=7.5,7.4,1.1 \mathrm{~Hz}, 0.46 \mathrm{H}, E)$.

${ }^{13}$ C-NMR $\left(125 \mathrm{MHz}, \mathrm{CDCl}_{3}\right): \delta=154.8\left(\mathrm{C}_{\mathrm{q}}\right), 151.1\left(\mathrm{C}_{\mathrm{q}}\right), 149.5(\mathrm{CH}), 138.4\left(\mathrm{C}_{\mathrm{q}}\right), 138.4(\mathrm{CH}), 134.9$ $(\mathrm{CH}), 133.2(\mathrm{CH}), 132.2\left(\mathrm{C}_{\mathrm{q}}\right), 128.8\left(\mathrm{C}_{\mathrm{q}}\right), 121.9(\mathrm{CH}), 120.5(\mathrm{CH}), 112.2\left(\mathrm{C}_{\mathrm{q}}\right), 111.7(\mathrm{CH}), 110.8$ $(\mathrm{CH}), 103.0(\mathrm{CH}), 102.3(\mathrm{CH}), 55.8\left(\mathrm{CH}_{3}\right), 33.6\left(\mathrm{CH}_{2}, E\right), 31.0\left(\mathrm{CH}_{2}, E\right), 28.6\left(\mathrm{CH}_{2}, Z\right), 26.3\left(\mathrm{CH}_{2}, Z\right)$, $23.1(\mathrm{CH}, E), 22.7(\mathrm{CH}, \mathrm{Z})$. 
IR (ATR): 2254, 1616, 1582, 1470, 1436, 1203, 1172, $729 \mathrm{~cm}^{-1}$.

MS (ESI) $m / z$ (relative intensity): $365(100)[\mathrm{M}+\mathrm{H}]^{+}, 343(40), 227(80)$.

HR-MS (ESI) $m / z$ calcd. for $\mathrm{C}_{21} \mathrm{H}_{19} \mathrm{~N}_{4} \mathrm{O}^{+}[\mathrm{M}+\mathrm{H}]^{+} 365.1373$, found 365.1365.

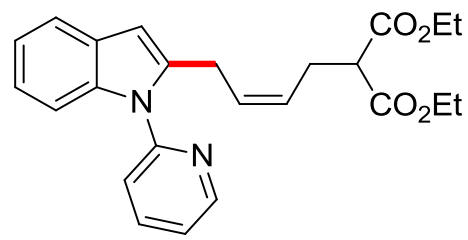

\section{(Z)-Diethyl 2-\{4-[1-(Pyridin-2-yl)-1H-indol-2-yl]but-2-en-1-yl\}malonate [(Z)-151ac]:}

The general procedure $\mathbf{F}$ was followed using (pyridin-2-yl)- $1 H$-indole (95a) (97.1 mg, $0.50 \mathrm{mmol}$ ) and diethyl 2-vinylcyclopropane-1,1-dicarboxylate (138c) $(127 \mathrm{mg}, 0.60 \mathrm{mmol})$. Isolation by column chromatography ( $n$-hexane/EtOAc: $3 / 1)$ yielded $(Z)$-151ac $(171 \mathrm{mg}, 84 \%, E / Z=1: 12)$ as a yellow oil. ${ }^{1}$ H-NMR $\left(300 \mathrm{MHz}, \mathrm{CDCl}_{3}\right): \delta=8.64$ (ddd, $\left.J=4.9,2.0,0.8 \mathrm{~Hz}, 1 \mathrm{H}\right), 7.90-7.83(\mathrm{~m}, 1 \mathrm{H}), 7.56-7.53$ $(\mathrm{m}, 1 \mathrm{H}), 7.42(\mathrm{dt}, J=8.0,8.0,1.0 \mathrm{~Hz}, 1 \mathrm{H}), 7.33-7.25(\mathrm{~m}, 2 \mathrm{H}), 7.13-7.08(\mathrm{~m}, 2 \mathrm{H}), 6.44(\mathrm{~d}, J=0.9 \mathrm{~Hz}$, $1 \mathrm{H}), 5.62(\mathrm{dtt}, J=10.8,7.4,1.4 \mathrm{~Hz}, 1 \mathrm{H}), 5.41(\mathrm{dtt}, J=10.8,7.6,1.0 \mathrm{~Hz}, 1 \mathrm{H}), 4.15(\mathrm{q}, J=7.2 \mathrm{~Hz}, 4 \mathrm{H})$, $3.64(\mathrm{~d}, J=7.4 \mathrm{~Hz}, 1.84 \mathrm{H}, Z), 3.55(\mathrm{~d}, J=7.4 \mathrm{~Hz}, 0.16 \mathrm{H}, E), 3.33(\mathrm{t}, J=7.6 \mathrm{~Hz}, 1 \mathrm{H}), 2.60(\mathrm{ddd}, J=7.6$, $7.6,1.4 \mathrm{~Hz}, 2 \mathrm{H}), 1.23(\mathrm{t}, J=7.2 \mathrm{~Hz}, 6 \mathrm{H})$.

${ }^{13}$ C-NMR (75 MHz, $\left.\mathrm{CDCl}_{3}\right): \delta=168.7\left(\mathrm{C}_{\mathrm{q}}\right), 151.1\left(\mathrm{C}_{\mathrm{q}}\right), 149.5(\mathrm{CH}), 139.2\left(\mathrm{C}_{\mathrm{q}}\right), 138.1(\mathrm{CH}), 137.1$ $\left(\mathrm{C}_{\mathrm{q}}\right), 128.6(\mathrm{CH}), 128.4(\mathrm{CH}), 126.4\left(\mathrm{C}_{\mathrm{q}}\right), 121.8(\mathrm{CH}), 121.6(\mathrm{CH}), 120.8(\mathrm{CH}), 120.5(\mathrm{CH}), 119.8$ $(\mathrm{CH}), 109.9(\mathrm{CH}), 102.6(\mathrm{CH}), 61.2\left(\mathrm{CH}_{2}\right), 51.7(\mathrm{CH}), 31.4\left(\mathrm{CH}_{2}, E\right), 30.7\left(\mathrm{CH}_{2}, E\right), 26.4\left(\mathrm{CH}_{2}, Z\right)$, $25.8\left(\mathrm{CH}_{2}, \mathrm{Z}\right), 13.9\left(\mathrm{CH}_{3}\right)$.

IR (ATR): 1727, 1585, 1468, 1455, 1436, 1149, 1025, 783, $745 \mathrm{~cm}^{-1}$.

MS (ESI) $m / z$ (relative intensity): $429(60)[\mathrm{M}+\mathrm{Na}]^{+}, 407(100)[\mathrm{M}+\mathrm{H}]^{+}$.

HR-MS (ESI) $m / z$ calcd. for $\mathrm{C}_{24} \mathrm{H}_{27} \mathrm{~N}_{2} \mathrm{O}_{4}{ }^{+}[\mathrm{M}+\mathrm{H}]^{+}$407.1965, found 407.1960. 


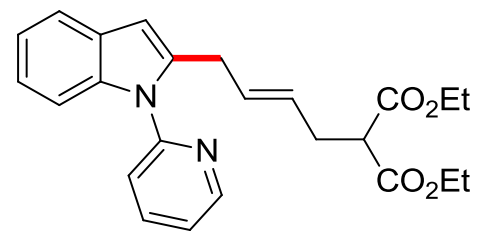

(E)-Diethyl 2-\{4-[1-(Pyridin-2-yl)-1H-indol-2-yl]but-2-en-1-yl\}malonate [(E)-151ac']:

The general procedure $\mathbf{G}$ was followed using (pyridin-2-yl)- $1 H$-indole (95a) (48.5 mg, $0.25 \mathrm{mmol})$ and diethyl 2-vinylcyclopropane-1,1-dicarboxylate (138c) $(63.5 \mathrm{mg}, 0.30 \mathrm{mmol})$. Isolation by column chromatography ( $n$-hexane/EtOAc: $3 / 1)$ yielded $(E)$-151ac' $(66.1 \mathrm{mg}, 65 \%, E / Z=1.3: 1)$ as a yellow oil.

${ }^{1}$ H-NMR $\left(300 \mathrm{MHz}, \mathrm{CDCl}_{3}\right): \delta=8.67-8.60$ (m, 1H), 7.90-7.82 (m, 1H), 7.57-7.51 (m, 1H), 7.46$7.38(\mathrm{~m}, 1 \mathrm{H}), 7.34-7.26(\mathrm{~m}, 2 \mathrm{H}), 7.14-7.07(\mathrm{~m}, 2 \mathrm{H}), 6.41(\mathrm{~d}, J=0.8 \mathrm{~Hz}, 1 \mathrm{H}), 5.67-5.55(\mathrm{~m}, 1 \mathrm{H})$, $5.41(\mathrm{dtt}, J=10.8,7.6,1.0 \mathrm{~Hz}, 0.43 \mathrm{H}, Z), 5.32(\mathrm{dtt}, J=15.3,7.6,1.0 \mathrm{~Hz}, 0.57 \mathrm{H}, E), 4.15(\mathrm{q}, J=7.2 \mathrm{~Hz}$, 4H), 3.65 (d, $J=7.4 \mathrm{~Hz}, 0.86 \mathrm{H}, Z$ ), 3.54 (d, $J=7.4 \mathrm{~Hz}, 1.14 \mathrm{H}, E), 3.29$ (t, $J=7.6 \mathrm{~Hz}, 1 \mathrm{H}$ ), 2.60 (ddd, $J=7.6,7.6,1.5 \mathrm{~Hz}, 0.86 \mathrm{H}, Z), 2.52(\mathrm{ddd}, J=7.6,7.6,1.5 \mathrm{~Hz}, 1.14 \mathrm{H}, E), 1.23(\mathrm{t}, J=7.2 \mathrm{~Hz}, 6 \mathrm{H})$.

${ }^{13}$ C-NMR $\left(100 \mathrm{MHz}, \mathrm{CDCl}_{3}\right): \delta=168.9\left(\mathrm{C}_{\mathrm{q}}\right), 151.4\left(\mathrm{C}_{\mathrm{q}}\right), 149.5(\mathrm{CH}), 139.3\left(\mathrm{C}_{\mathrm{q}}\right), 138.2(\mathrm{CH}), 137.3$ $\left(\mathrm{C}_{\mathrm{q}}\right), 129.6(\mathrm{CH}), 128.8(\mathrm{CH}), 128.5\left(\mathrm{C}_{\mathrm{q}}\right), 127.8(\mathrm{CH}), 126.6(\mathrm{CH}), 121.8(\mathrm{CH}), 121.0(\mathrm{CH}), 120.0$ $(\mathrm{CH}), 110.1(\mathrm{CH}), 103.0(\mathrm{CH}), 61.3\left(\mathrm{CH}_{2}\right), 51.9(\mathrm{CH}), 31.5\left(\mathrm{CH}_{2}, E\right), 30.6\left(\mathrm{CH}_{2}, E\right), 26.7\left(\mathrm{CH}_{2}, \mathrm{Z}\right)$, $25.9\left(\mathrm{CH}_{2}, \mathrm{Z}\right), 14.0\left(\mathrm{CH}_{3}\right)$.

IR (ATR): 1728, 1585, 1469, 1436, 1149, 782, $746 \mathrm{~cm}^{-1}$.

MS (ESI) $m / z$ (relative intensity): $429(100)[\mathrm{M}+\mathrm{Na}]^{+}, 407(20)[\mathrm{M}+\mathrm{H}]^{+}$.

HR-MS (ESI) $m / z$ calcd. for $\mathrm{C}_{24} \mathrm{H}_{27} \mathrm{~N}_{2} \mathrm{O}_{4}{ }^{+}[\mathrm{M}+\mathrm{H}]^{+}$407.1965, found 407.1966. 


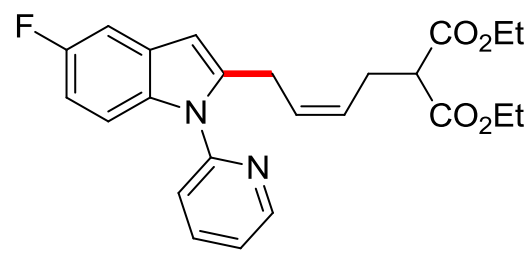

\section{(Z)-Diethyl 2-\{4-[5-Fluoro-1-(pyridin-2-yl)-1H-indol-2-yl]but-2-en-1-yl\}malonate [(Z)-151bc]:}

The general procedure $\mathbf{F}$ was followed using 5-fluoro-1-(pyridin-2-yl)-1H-indole (95b) (106 mg, $0.50 \mathrm{mmol}$ ) and diethyl 2-vinylcyclopropane-1,1-dicarboxylate (138c) (127 mg, $0.60 \mathrm{mmol}$ ). Isolation by column chromatography ( $n$-hexane/EtOAc: $3 / 1)$ yielded $(Z)-151 b c(166 \mathrm{mg}, 78 \%, E / Z=1: 11)$ as a yellow oil.

${ }^{1}$ H-NMR $\left(300 \mathrm{MHz}, \mathrm{CDCl}_{3}\right): \delta=8.64-8.60(\mathrm{~m}, 1 \mathrm{H}), 7.89-7.82(\mathrm{~m}, 1 \mathrm{H}), 7.38(\mathrm{~d}, J=8.0 \mathrm{~Hz}, 1 \mathrm{H})$, 7.32-7.26 (m, 1H), 7.22-7.14 (m, 2H), $6.82(\mathrm{td}, J=9.1,2.6 \mathrm{~Hz}, 1 \mathrm{H}), 6.37(\mathrm{~s}, 1 \mathrm{H}), 5.59$ (dtt, $J=10.8$, 7.5, $1.4 \mathrm{~Hz}, 1 \mathrm{H}), 5.40(\mathrm{dtt}, J=10.8,7.6,1.2 \mathrm{~Hz}, 1 \mathrm{H}), 4.13(\mathrm{q}, J=7.2 \mathrm{~Hz}, 4 \mathrm{H}), 3.61(\mathrm{~d}, J=7.5 \mathrm{~Hz}$, $1.83 \mathrm{H}, Z), 3.50(\mathrm{~d}, J=7.5 \mathrm{~Hz}, 0.17 \mathrm{H}, E), 3.29(\mathrm{t}, J=7.5 \mathrm{~Hz}, 1 \mathrm{H}), 2.58(\mathrm{ddd}, J=7.6,7.6,1.4 \mathrm{~Hz}$, $2 \mathrm{H}), 1.21(\mathrm{t}, J=7.2 \mathrm{~Hz}, 6 \mathrm{H})$.

${ }^{13}$ C-NMR $\left(75 \mathrm{MHz}, \mathrm{CDCl}_{3}\right): \delta=168.8\left(\mathrm{C}_{\mathrm{q}}\right), 158.3\left(\mathrm{C}_{\mathrm{q}},{ }^{1} J_{\mathrm{C}-\mathrm{F}}=234.2 \mathrm{~Hz}\right), 151.0\left(\mathrm{C}_{\mathrm{q}}\right), 149.6(\mathrm{CH})$, $140.9\left(\mathrm{C}_{\mathrm{q}}\right), 138.4(\mathrm{CH}), 133.8\left(\mathrm{C}_{\mathrm{q}}\right), 128.8\left(\mathrm{C}_{\mathrm{q}},{ }^{3} J_{\mathrm{C}-\mathrm{F}}=9.7 \mathrm{~Hz}\right), 128.2(\mathrm{CH}), 126.8(\mathrm{CH}), 122.1(\mathrm{CH})$, $120.8(\mathrm{CH}), 110.7\left(\mathrm{CH},{ }^{3} J_{\mathrm{C}-\mathrm{F}}=9.6 \mathrm{~Hz}\right), 109.6\left(\mathrm{CH},{ }^{2} J_{\mathrm{C}-\mathrm{F}}=25.8 \mathrm{~Hz}\right), 104.3\left(\mathrm{CH},{ }^{2} J_{\mathrm{C}-\mathrm{F}}=25.5 \mathrm{~Hz}\right)$, $102.6\left(\mathrm{CH},{ }^{4} J_{\mathrm{C}-\mathrm{F}}=4.2 \mathrm{~Hz}\right), 61.3\left(\mathrm{CH}_{2}\right), 51.7(\mathrm{CH}), 31.5\left(\mathrm{CH}_{2}, E\right), 30.9\left(\mathrm{CH}_{2}, E\right), 26.5\left(\mathrm{CH}_{2}, \mathrm{Z}\right), 25.9$ $\left(\mathrm{CH}_{2}, \mathrm{Z}\right), 13.9\left(\mathrm{CH}_{3}\right)$.

${ }^{19}$ F-NMR (282 MHz, $\left.\mathrm{CDCl}_{3}\right): \delta=-124.0$. IR (ATR): 1727, 1584, 1469, 1437, 1173, 1151, 1031, 855, $785 \mathrm{~cm}^{-1}$.

MS (ESI) $\mathrm{m} / z$ (relative intensity): $447(90)[\mathrm{M}+\mathrm{Na}]^{+}, 425(100)[\mathrm{M}+\mathrm{H}]^{+}$.

HR-MS (ESI) $m / z$ calcd. for $\mathrm{C}_{24} \mathrm{H}_{26} \mathrm{FN}_{2} \mathrm{O}_{4}{ }^{+}[\mathrm{M}+\mathrm{H}]^{+} 425.1871$, found 425.1875 . 
<smiles>CCOC(=O)C(C/C=C\Cc1cc2cc(OC)ccc2n1-c1ccccn1)C(=O)OCC</smiles>

(Z)-Diethyl 2-\{4-[5-Methoxy-1-(pyridin-2-yl)-1H-indol-2-yl]but-2-en-1-yl\}malonate [(Z)-151dc]: The general procedure $\mathbf{F}$ was followed using 5-methoxy-1-(pyridin-2-yl)-1H-indole (95d) (112 mg, $0.50 \mathrm{mmol}$ ) and diethyl 2-vinylcyclopropane-1,1-dicarboxylate (138c) (127 $\mathrm{mg}, 0.60 \mathrm{mmol})$. Isolation by column chromatography ( $n$-hexane/EtOAc: $3 / 1)$ yielded $(Z)$-151dc $(142 \mathrm{mg}, 65 \%, E / Z=1: 12)$ as a yellow oil.

${ }^{1}$ H-NMR $\left(400 \mathrm{MHz}, \mathrm{CDCl}_{3}\right): \delta=8.60(\mathrm{ddd}, J=4.9,2.0,0.8 \mathrm{~Hz}, 1 \mathrm{H}), 7.83(\mathrm{ddd}, J=8.0,7.5,2.0 \mathrm{~Hz}$, 1H), $7.39(\mathrm{dt}, J=8.0,1.0 \mathrm{~Hz}, 1 \mathrm{H}), 7.25(\mathrm{ddd}, J=7.5,4.9,1.0 \mathrm{~Hz}, 1 \mathrm{H}), 7.24-7.21(\mathrm{~m}, 1 \mathrm{H}), 7.01(\mathrm{~d}, J=$ $2.5 \mathrm{~Hz}, 1 \mathrm{H}), 6.75(\mathrm{dd}, J=8.9,2.5 \mathrm{~Hz}, 1 \mathrm{H}), 6.34(\mathrm{~d}, J=0.9 \mathrm{~Hz}, 1 \mathrm{H}), 5.60(\mathrm{dtt}, J=10.8,7.3,1.2 \mathrm{~Hz}, 1 \mathrm{H})$, $5.39(\mathrm{dtt}, J=10.8,7.5,1.2 \mathrm{~Hz}, 1 \mathrm{H}), 4.14(\mathrm{q}, J=7.1 \mathrm{~Hz}, 4 \mathrm{H}), 3.81(\mathrm{~s}, 3 \mathrm{H}), 3.63(\mathrm{~d}, J=7.3 \mathrm{~Hz}, 1.84 \mathrm{H}$, $Z$ ), $3.53(\mathrm{~d}, J=7.3 \mathrm{~Hz}, 0.16 \mathrm{H}, E), 3.30$ (t, $J=7.6 \mathrm{~Hz}, 1 \mathrm{H}), 2.59$ (ddd, $J=7.6,7.5,1.2 \mathrm{~Hz}, 1.84 \mathrm{H}, Z$ ), 2.51 (ddd, $J=7.6,7.5,1.2 \mathrm{~Hz}, 0.16 \mathrm{H}, E), 1.20(\mathrm{t}, J=7.2 \mathrm{~Hz}, 6 \mathrm{H})$.

${ }^{13}$ C-NMR $\left(100 \mathrm{MHz}, \mathrm{CDCl}_{3}\right): \delta=168.8\left(\mathrm{C}_{\mathrm{q}}\right), 154.7\left(\mathrm{C}_{\mathrm{q}}\right), 151.3\left(\mathrm{C}_{\mathrm{q}}\right), 149.5(\mathrm{CH}), 139.8\left(\mathrm{C}_{\mathrm{q}}\right), 138.2$ $(\mathrm{CH}), 132.3\left(\mathrm{C}_{\mathrm{q}}\right), 129.0\left(\mathrm{C}_{\mathrm{q}}\right), 128.7(\mathrm{CH}), 126.4(\mathrm{CH}), 121.7(\mathrm{CH}), 120.6(\mathrm{CH}), 111.2(\mathrm{CH}), 110.8$ $(\mathrm{CH}), 102.6(\mathrm{CH}), 102.2(\mathrm{CH}), 61.3\left(\mathrm{CH}_{2}\right), 55.7\left(\mathrm{CH}_{3}\right), 51.8(\mathrm{CH}), 31.5\left(\mathrm{CH}_{2}, E\right), 30.6\left(\mathrm{CH}_{2}, E\right), 26.7$ $\left(\mathrm{CH}_{2}, \mathrm{Z}\right), 26.0\left(\mathrm{CH}_{2}, \mathrm{Z}\right), 14.0\left(\mathrm{CH}_{3}\right)$.

IR (ATR): 1727, 1581, 1470, 1436, 1203, 1171, 1151, 1031, 770, $712 \mathrm{~cm}^{-1}$.

MS (ESI) $m / z$ (relative intensity): $459(100)[\mathrm{M}+\mathrm{Na}]^{+}, 437(90)[\mathrm{M}+\mathrm{H}]^{+}$.

HR-MS (ESI) $m / z$ calcd. for $\mathrm{C}_{25} \mathrm{H}_{29} \mathrm{~N}_{2} \mathrm{O}_{5}{ }^{+}[\mathrm{M}+\mathrm{H}]^{+}$437.2071, found 437.2071. 
<smiles>COC(=O)C(C/C=C\Cc1ccc(C)cc1-c1ccccn1)C(C)=O</smiles>

\section{(Z)-Dimethyl 2-\{4-[4-methyl-2-(pyridin-2-yl)phenyl]but-2-en-1-yl\}malonate [(Z)-153aa]:}

The general procedure $\mathbf{F}$ was followed using 2-( $m$-tolyl)pyridine (152a) $(42.3 \mathrm{mg}, 0.25 \mathrm{mmol})$ and dimethyl 2-vinylcyclopropane-1,1-dicarboxylate (138a) $(55.2 \mathrm{mg}, 0.30 \mathrm{mmol})$. Isolation by column chromatography ( $n$-hexane/EtOAc: $3 / 1)$ yielded $(Z)$-153aa $(61.8 \mathrm{mg}, 70 \%, E / Z=1: 3)$.

${ }^{1}$ H-NMR $\left(500 \mathrm{MHz}, \mathrm{CDCl}_{3}\right): \delta=8.67-8.65(\mathrm{~m}, 1 \mathrm{H}), 7.73-7.67(\mathrm{~m}, 1 \mathrm{H}), 7.37-7.32(\mathrm{~m}, 1 \mathrm{H}), 7.17(\mathrm{~s}$, $1 \mathrm{H}), 7.16-7.11(\mathrm{~m}, 3 \mathrm{H}), 5.55(\mathrm{dtt}, J=15.1,7.6,1.4 \mathrm{~Hz}, 0.25 \mathrm{H}, E), 5.49(\mathrm{dtt}, J=10.8,7.6,1.4 \mathrm{~Hz}$, $0.75 \mathrm{H}, Z), 5.29-5.18$ (m, 1H), 3.68 (s, 4.62H, Z), 3.66 (s, 1.38H, E), 3.45 (d, J = 7.2 Hz, 2H), 3.34 $3.29(\mathrm{~m}, 1 \mathrm{H}), 2.55(\mathrm{ddd}, J=7.7,7.6,1.3 \mathrm{~Hz}, 1.54 \mathrm{H}, Z), 2.51(\mathrm{ddd}, J=7.7,7.6,1.3 \mathrm{~Hz}, 0.46 \mathrm{H}, E)$, $2.33(\mathrm{~s}, 3 \mathrm{H})$.

${ }^{13}$ C-NMR (125 MHz, $\left.\mathrm{CDCl}_{3}\right): \delta=169.3\left(\mathrm{C}_{\mathrm{q}}\right), 159.9\left(\mathrm{C}_{\mathrm{q}}\right), 149.2(\mathrm{CH}), 140.1\left(\mathrm{C}_{\mathrm{q}}\right), 136.1(\mathrm{CH}), 135.7$ $\left(\mathrm{C}_{\mathrm{q}}\right), 135.1\left(\mathrm{C}_{\mathrm{q}}\right), 132.1(\mathrm{CH}), 130.4(\mathrm{CH}), 129.6(\mathrm{CH}), 129.2(\mathrm{CH}), 124.7(\mathrm{CH}), 124.1(\mathrm{CH}), 121.6$ $(\mathrm{CH}), 52.5\left(\mathrm{CH}_{3}, E\right), 52.4\left(\mathrm{CH}_{3}, Z\right), 51.7(\mathrm{CH}, \mathrm{Z}), 51.5(\mathrm{CH}, E), 35.7\left(\mathrm{CH}_{2}, E\right), 31.8\left(\mathrm{CH}_{2}, E\right), 30.5$ $\left(\mathrm{CH}_{2}, \mathrm{Z}\right), 26.6\left(\mathrm{CH}_{2}, \mathrm{Z}\right), 20.9\left(\mathrm{CH}_{3}\right)$.

IR (ATR): 1734, 1586, 1433, 1339, 1271, 1231, 1196, 1152, $749 \mathrm{~cm}^{-1}$.

MS (ESI) $m / z$ (relative intensity): $376(70)[\mathrm{M}+\mathrm{Na}]^{+}, 354(100)[\mathrm{M}+\mathrm{H}]^{+}$.

HR-MS (ESI) $m / z$ calcd. for $\mathrm{C}_{21} \mathrm{H}_{24} \mathrm{NO}_{4}{ }^{+}[\mathrm{M}+\mathrm{H}]^{+} 354.1700$, found 354.1702 . 
<smiles>CC(=O)C(C/C=C/Cc1ccc(C)cc1-c1ccccn1)C(C)=O</smiles>

\section{(E)-Dimethyl 2-\{4-[4-methyl-2-(pyridin-2-yl)phenyl]but-2-en-1-yl\}malonate [(E)-153aa']:}

The general procedure $\mathbf{G}$ was followed using 2-( $m$-tolyl)pyridine (152a) (42.3 $\mathrm{mg}, 0.25 \mathrm{mmol})$ and dimethyl 2-vinylcyclopropane-1,1-dicarboxylate (138a) $(55.2 \mathrm{mg}, 0.30 \mathrm{mmol})$. Isolation by column chromatography ( $n$-hexane/EtOAc: $3 / 1)$ yielded $(E)$-153aa' $(30.1 \mathrm{mg}, 34 \%, E / Z=2: 1)$.

${ }^{1}$ H-NMR $\left(500 \mathrm{MHz}, \mathrm{CDCl}_{3}\right): \delta=8.66(\mathrm{ddd}, J=4.9,1.7,0.9 \mathrm{~Hz}, 1 \mathrm{H}), 7.73-7.68(\mathrm{~m}, 1 \mathrm{H}), 7.37-7.32$ $(\mathrm{m}, 1 \mathrm{H}), 7.17(\mathrm{~s}, 1 \mathrm{H}), 7.16-7.11(\mathrm{~m}, 3 \mathrm{H}), 5.55(\mathrm{dtt}, J=15.1,7.6,1.4 \mathrm{~Hz}, 0.67 \mathrm{H}, E), 5.49(\mathrm{dtt}, J=$ 10.8, 7.6, 1.4 Hz, 0.33H, Z), 5.27-5.18 (m, 1H), 3.68 (s, 2.00H, Z), 3.66 (s, 4.00H, E), 3.46-3.29 (m, 3H), 2.55 (ddd, $J=7.7,7.6,1.3 \mathrm{~Hz}, 0.66 \mathrm{H}, Z$ ), 2.51 (ddd, $J=7.7,7.6,1.3 \mathrm{~Hz}, 1.34 \mathrm{H}, E), 2.33$ (s, $3 \mathrm{H})$.

${ }^{13}$ C-NMR (125 MHz, $\left.\mathrm{CDCl}_{3}\right): \delta=169.3\left(\mathrm{C}_{\mathrm{q}}\right), 159.8\left(\mathrm{C}_{\mathrm{q}}\right), 149.1(\mathrm{CH}), 140.1\left(\mathrm{C}_{\mathrm{q}}\right), 136.0(\mathrm{CH}), 135.7$ $\left(\mathrm{C}_{\mathrm{q}}\right), 134.7\left(\mathrm{C}_{\mathrm{q}}\right), 132.9(\mathrm{CH}), 130.4(\mathrm{CH}), 129.8(\mathrm{CH}), 129.1(\mathrm{CH}), 126.2(\mathrm{CH}), 124.1(\mathrm{CH}), 121.6$ $(\mathrm{CH}), 52.5\left(\mathrm{CH}_{3}\right), 52.4\left(\mathrm{CH}_{3}\right), 51.7(\mathrm{CH}, \mathrm{Z}), 51.5(\mathrm{CH}, E), 35.7\left(\mathrm{CH}_{2}, E\right), 31.8\left(\mathrm{CH}_{2}, E\right), 30.5\left(\mathrm{CH}_{2}\right.$, $\mathrm{Z}), 26.6\left(\mathrm{CH}_{2}, \mathrm{Z}\right), 20.9\left(\mathrm{CH}_{3}\right)$.

IR (ATR): 1732, 1599, 1434, 1230, 1151, 829, 972, 773, $752 \mathrm{~cm}^{-1}$.

MS (ESI) $m / z$ (relative intensity): $376(80)[\mathrm{M}+\mathrm{Na}]^{+}, 354(100)[\mathrm{M}+\mathrm{H}]^{+}$.

HR-MS (ESI) $m / z$ calcd. for $\mathrm{C}_{21} \mathrm{H}_{24} \mathrm{NO}_{4}{ }^{+}[\mathrm{M}+\mathrm{H}]^{+} 354.1700$, found 354.1701. 
<smiles>COc1ccc(C/C=C\CC(C(C)=O)C(C)=O)c(-c2ccccn2)c1</smiles>

\section{(Z)-Dimethyl 2-\{4-[4-methoxy-2-(pyridin-2-yl)phenyl]but-2-en-1-yl\} malonate [(Z)-153ba]:}

The general procedure $\mathbf{F}$ was followed using 2-(3-methoxyphenyl)pyridine (152b) (46.3 mg, $0.25 \mathrm{mmol}$ ) and dimethyl 2-vinylcyclopropane-1,1-dicarboxylate (138a) (55.2 $\mathrm{mg}, 0.30 \mathrm{mmol})$. Isolation by column chromatography ( $n$-hexane/EtOAc: $3 / 1)$ yielded $(Z)-153 b a(58.1 \mathrm{mg}, 63 \%, E / Z$ $=1: 5)$.

${ }^{1}$ H-NMR $\left(300 \mathrm{MHz}, \mathrm{CDCl}_{3}\right): \delta=8.68-8.64(\mathrm{~m}, 1 \mathrm{H}), 7.72(\mathrm{ddd}, J=6.7,4.8,1.8 \mathrm{~Hz}, 1 \mathrm{H}), 7.37-7.33$ $(\mathrm{m}, 1 \mathrm{H}), 7.24-7.20(\mathrm{~m}, 1 \mathrm{H}), 7.19-7.14(\mathrm{~m}, 1 \mathrm{H}), 6.89(\mathrm{~s}, 1 \mathrm{H}), 6.87-6.85(\mathrm{~m}, 1 \mathrm{H}), 5.56(\mathrm{dtt}, J=15.3$, 7.6, $1.4 \mathrm{~Hz}, 0.17 \mathrm{H}, E), 5.47(\mathrm{dtt}, J=10.8,7.6,1.4 \mathrm{~Hz}, 0.83 \mathrm{H}, Z), 5.30-5.14(\mathrm{~m}, 1 \mathrm{H}), 3.79(\mathrm{~s}, 3 \mathrm{H})$, $3.69(\mathrm{~s}, 5.00 \mathrm{H}, Z), 3.67(\mathrm{~s}, 1.00 \mathrm{H}, E), 3.41(\mathrm{~d}, J=7.2 \mathrm{~Hz}, 2 \mathrm{H}), 3.34-3.28$ (m, 1H), 2.55 (ddd, $J=7.6$, $7.5,1.3 \mathrm{~Hz}, 2 \mathrm{H})$.

${ }^{13}$ C-NMR $\left(125 \mathrm{MHz}, \mathrm{CDCl}_{3}\right): \delta=169.2\left(\mathrm{C}_{\mathrm{q}}\right), 159.6\left(\mathrm{C}_{\mathrm{q}}\right), 157.7\left(\mathrm{C}_{\mathrm{q}}\right), 149.1(\mathrm{CH}), 141.1\left(\mathrm{C}_{\mathrm{q}}\right), 136.1$ $(\mathrm{CH}), 132.1(\mathrm{CH}), 130.6(\mathrm{CH}), 130.3\left(\mathrm{C}_{\mathrm{q}}\right), 124.6(\mathrm{CH}), 124.0(\mathrm{CH}), 121.7(\mathrm{CH}), 114.9(\mathrm{CH}), 114.4$ $(\mathrm{CH}), 55.4\left(\mathrm{CH}_{3}\right), 52.5(\mathrm{CH}), 51.6\left(\mathrm{CH}_{3}\right), 35.3\left(\mathrm{CH}_{2}, E\right), 31.8\left(\mathrm{CH}_{2}, E\right), 30.2\left(\mathrm{CH}_{2}, \mathrm{Z}\right), 26.7\left(\mathrm{CH}_{2}, Z\right)$.

IR (ATR): 1732, 1607, 1586, 1499, 1469, 1224, 1230, 1150, 750, $611 \mathrm{~cm}^{-1}$.

MS (ESI) $m / z$ (relative intensity): $392(100)[\mathrm{M}+\mathrm{Na}]^{+}, 369(90)[\mathrm{M}]^{+}$.

HR-MS (ESI) $m / z$ calcd. for $\mathrm{C}_{21} \mathrm{H}_{24} \mathrm{NO}_{5}{ }^{+}[\mathrm{M}+\mathrm{H}]^{+} 370.1649$, found 370.1652 . 
<smiles>COC(=O)C(CC=CCc1ccc(OC)cc1-c1ccccn1)C(C)=O</smiles><smiles>COc1cccc(-c2ccccn2)c1CC=CCC(C(C)=O)C(C)=O</smiles>

$(E, Z)$-Dimethyl 2-\{4-[4-methoxy-2-(pyridin-2-yl)phenyl]but-2-en-1-yl\}malonate $\quad[(E, Z)-153 b a]$ and $(E, Z) D i m e t h y l$ 2\{4-[2-methoxy-6-(pyridin-2-yl)phenyl\}but-2-en-1-yl\}malonate $[(E, Z)-153 b a ']:$

The general procedure $\mathbf{G}$ was followed using 2-(3-methoxyphenyl)pyridine (152b) (46.3 mg, $0.25 \mathrm{mmol}$ ) and dimethyl 2-vinylcyclopropane-1,1-dicarboxylate (138a) (55.2 $\mathrm{mg}, 0.30 \mathrm{mmol}$ ). Isolation by column chromatography ( $n$-hexane/EtOAc: 5/1->3/1->2/1) yielded $(E, Z)$-153ba and (E,Z)-ba' as inseparable mixture $(22.2 \mathrm{mg}, 24 \%, E / Z=1: 1)$ and $(E, Z)-153 b a " ~(19.4 \mathrm{mg}, 14 \%, E / Z=$ $1: 1)$.

${ }^{1}$ H-NMR (300 MHz, $\left.\mathrm{CDCl}_{3}\right): \delta=8.68-8.63(\mathrm{~m}, 1 \mathrm{H}), 7.76-7.66(\mathrm{~m}, 1 \mathrm{H}), 7.34$ (ddd, $J=4.1,2.0,1.0$ $\mathrm{Hz}, 1 \mathrm{H}), 7.24-7.20(\mathrm{~m}, 1 \mathrm{H}), 7.19-7.14(\mathrm{~m}, 1 \mathrm{H}), 6.89(\mathrm{~s}, 1 \mathrm{H}), 6.87-6.85(\mathrm{~m}, 1 \mathrm{H}), 5.56(\mathrm{dtt}, J=15.3$, 7.6, $1.4 \mathrm{~Hz}, 0.50 \mathrm{H}, E), 5.47$ (dtt, $J=10.8,7.6,1.4 \mathrm{~Hz}, 0.50 \mathrm{H}, Z), 5.28-5.02(\mathrm{~m}, 1 \mathrm{H}), 3.85-3.79$ (s, $3 \mathrm{H}), 3.70-3.62(\mathrm{~s}, 6 \mathrm{H}), 3.47-3.22(\mathrm{~m}, 3 \mathrm{H}), 2.57-2.51(\mathrm{~m}, 2 \mathrm{H})$.

${ }^{13}$ C-NMR $\left(125 \mathrm{MHz}, \mathrm{CDCl}_{3}\right): \delta=169.2\left(\mathrm{C}_{\mathrm{q}}\right), 159.5\left(\mathrm{C}_{\mathrm{q}}\right), 157.7\left(\mathrm{C}_{\mathrm{q}}\right), 149.1(\mathrm{CH}), 141.2\left(\mathrm{C}_{\mathrm{q}}\right), 136.0$ $(\mathrm{CH}), 135.4(\mathrm{CH}), 132.9(\mathrm{CH}), 130.9\left(\mathrm{C}_{\mathrm{q}}\right), 126.1(\mathrm{CH}), 124.2(\mathrm{CH}), 121.7(\mathrm{CH}), 114.4(\mathrm{CH}), 110.4$ $(\mathrm{CH}), 55.4\left(\mathrm{CH}_{3}\right), 52.4\left(\mathrm{CH}_{3}\right), 51.9(\mathrm{CH}), 35.4\left(\mathrm{CH}_{2}, E\right), 31.8\left(\mathrm{CH}_{2}, E\right), 26.6\left(\mathrm{CH}_{2}, Z\right), 25.1\left(\mathrm{CH}_{2}, Z\right)$. IR (ATR): 1732, 1607, 1586, 1499, 1469, 1224, 1230, 1150, 750, $611 \mathrm{~cm}^{-1}$.

MS (ESI) $m / z$ (relative intensity): $392(100)[\mathrm{M}+\mathrm{Na}]^{+}, 369(90)[\mathrm{M}]^{+}$.

HR-MS (ESI) $m / z$ calcd. for $\mathrm{C}_{21} \mathrm{H}_{24} \mathrm{NO}_{5}{ }^{+}[\mathrm{M}+\mathrm{H}]^{+} 370.1649$, found 370.1652. 
<smiles>COC(=O)C(CC=CCc1ccc(OC)c(-c2ccccn2)c1CC=CCC(C(C)=O)C(C)=O)C(C)=O</smiles>

(2E,Z,2' $E, Z)$-Tetramethyl [4-methoxy-2-(pyridin-2-yl)-1,3-phenylenebis(but-2-ene-4,1-diyl)]dimalonate $[(E, Z)-153 b a "]$ :

${ }^{1}$ H-NMR $\left(300 \mathrm{MHz}, \mathrm{CDCl}_{3}\right): \delta=8.66(\mathrm{ddd}, J=4.9,1.8,1.0 \mathrm{~Hz}, 1 \mathrm{H}), 7.72-7.65(\mathrm{~m}, 1 \mathrm{H}), 7.23-7.17$ (m, 1H), $7.14(\mathrm{dt}, J=7.7,1.1 \mathrm{~Hz}, 1 \mathrm{H}), 7.04-7.00(\mathrm{~m}, 1 \mathrm{H}), 6.83(\mathrm{~d}, J=1.6 \mathrm{~Hz}, 1 \mathrm{H}), 5.51-5.39(\mathrm{~m}$, 2H), 5.15-4.88 (m, 2H), $3.79(\mathrm{~s}, 3 \mathrm{H}), 3.66(\mathrm{~s}, 12 \mathrm{H}), 3.31(\mathrm{t}, J=6.2 \mathrm{~Hz}, 2 \mathrm{H}), 3.11-2.80(\mathrm{~m}, 4 \mathrm{H})$, $2.53-2.39(\mathrm{~m}, 4 \mathrm{H})$.

${ }^{13}$ C-NMR (125 MHz, $\left.\mathrm{CDCl}_{3}\right): \delta=169.2\left(\mathrm{C}_{\mathrm{q}}\right), 158.7\left(\mathrm{C}_{\mathrm{q}}\right), 155.8\left(\mathrm{C}_{\mathrm{q}}\right), 149.2(\mathrm{CH}), 141.0\left(\mathrm{C}_{\mathrm{q}}\right), 135.5$ $(\mathrm{CH}), 132.5(\mathrm{CH}), 131.7(\mathrm{CH}), 130.2\left(\mathrm{C}_{\mathrm{q}}\right), 127.6(\mathrm{CH}), 126.6\left(\mathrm{C}_{\mathrm{q}}\right), 125.9(\mathrm{CH}), 125.1(\mathrm{CH}), 121.7$ $(\mathrm{CH}), 110.4(\mathrm{CH}), 55.7\left(\mathrm{CH}_{3}\right), 52.4\left(\mathrm{CH}_{3}\right), 52.0(\mathrm{CH}), 36.1\left(\mathrm{CH}_{2}, E\right), 31.9\left(\mathrm{CH}_{2}, E\right), 30.6\left(\mathrm{CH}_{2}, Z\right)$, $26.6\left(\mathrm{CH}_{2}, \mathrm{Z}\right)$.

IR (ATR): 1732, 1584, 1466, 1434, 1257, 1151, 1033, 972, $731 \mathrm{~cm}^{-1}$.

MS (ESI) $m / z$ (relative intensity): $554(80)[\mathrm{M}+\mathrm{H}]^{+}, 553(100)[\mathrm{M}]^{+}$.

HR-MS (ESI) $m / z$ calcd. for $\mathrm{C}_{30} \mathrm{H}_{36} \mathrm{NO}_{9}{ }^{+}[\mathrm{M}+\mathrm{H}]^{+}$554.2385, found 554.2389.<smiles>COC(=O)C(C/C=C\Cc1ccccc1-n1cccn1)C(C)=O</smiles>

\section{(Z)-Dimethyl 2-\{4-[2-(1H-pyrazol-1-yl)phenyl]but-2-en-1-yl\}malonate [(Z)-153ca]:}

The general procedure $\mathbf{F}$ was followed using 1-phenyl-1 $H$-pyrazole (152c) $(72.1 \mathrm{mg}, 0.50 \mathrm{mmol})$ and dimethyl 2-vinylcyclopropane-1,1-dicarboxylate (138a) (110 mg, $0.60 \mathrm{mmol})$. Isolation by column chromatography ( $n$-hexane/EtOAc: $3 / 1)$ yielded $(Z)$-153ca $(117 \mathrm{mg}, 71 \%, E / Z=1: 12)$ as a yellow oil. 
${ }^{1}$ H-NMR $\left(500 \mathrm{MHz}, \mathrm{CDCl}_{3}\right): \delta=7.66(\mathrm{dd}, J=2.4,0.7 \mathrm{~Hz}, 1 \mathrm{H}), 7.55(\mathrm{dd}, J=2.4,0.7 \mathrm{~Hz}, 1 \mathrm{H})$, $7.32-7.28(\mathrm{~m}, 2 \mathrm{H}), 7.25-7.24(\mathrm{~m}, 2 \mathrm{H}), 6.39-6.37$ (m, 1H), $5.43(\mathrm{dtt}, J=10.7,7.5,1.0 \mathrm{~Hz}, 1 \mathrm{H}), 5.32$ $(\mathrm{dtt}, J=10.7,7.5,1.4 \mathrm{~Hz}, 1 \mathrm{H}), 3.66(\mathrm{~s}, 6 \mathrm{H}), 3.34-3.31(\mathrm{~m}, 3 \mathrm{H}), 2.59(\mathrm{ddd}, J=7.6,7.5,1.0 \mathrm{~Hz}$, $1.84 \mathrm{H}), 2.53$ (ddd, $J=7.6,7.5,1.0 \mathrm{~Hz}, 0.16 \mathrm{H}$ ).

${ }^{13}$ C-NMR $\left(125 \mathrm{MHz}, \mathrm{CDCl}_{3}\right): \delta=169.1\left(\mathrm{C}_{\mathrm{q}}\right), 140.3(\mathrm{CH}), 139.5\left(\mathrm{C}_{\mathrm{q}}\right), 136.3\left(\mathrm{C}_{\mathrm{q}}\right), 130.6(\mathrm{CH}), 130.4$ $(\mathrm{CH}), 130.1(\mathrm{CH}), 128.6(\mathrm{CH}), 126.8(\mathrm{CH}), 126.4(\mathrm{CH}), 125.8(\mathrm{CH}), 106.2(\mathrm{CH}), 52.4\left(\mathrm{CH}_{3}\right), 51.3$ $(\mathrm{CH}), 34.1\left(\mathrm{CH}_{2}, E\right), 31.1\left(\mathrm{CH}_{2}, E\right), 29.0\left(\mathrm{CH}_{2}, \mathrm{Z}\right), 26.5\left(\mathrm{CH}_{2}, \mathrm{Z}\right)$.

IR (ATR): 1731, 1517, 1435, 1394, 1233, 1153, 911, 759, $730 \mathrm{~cm}^{-1}$.

MS (ESI) $m / z$ (relative intensity): $351(20)[\mathrm{M}+\mathrm{Na}]^{+}, 329(100)[\mathrm{M}+\mathrm{H}]^{+}$.

HR-MS (ESI) $m / z$ calcd. for $\mathrm{C}_{18} \mathrm{H}_{21} \mathrm{~N}_{2} \mathrm{O}_{4}{ }^{+}[\mathrm{M}+\mathrm{H}]^{+} 329.1496$, found 329.1497.

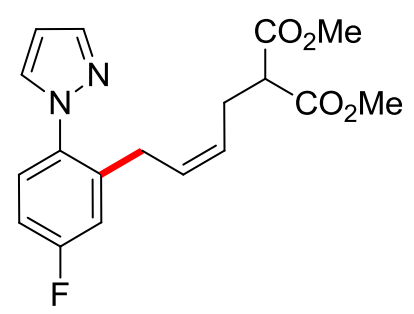

\section{(Z)-Dimethyl 2-\{4-[5-fluoro-2-(1H-pyrazol-1-yl)phenyl]but-2-en-1-yl\}malonate [( $Z)-153 d a]$ :}

The general procedure $\mathbf{F}$ was followed using 1-(4-fluorophenyl)-1H-pyrazole (152d) (81.2 mg, $0.50 \mathrm{mmol}$ ) and dimethyl 2-vinylcyclopropane-1,1-dicarboxylate (138a) (110 mg, $0.60 \mathrm{mmol}$ ). Isolation by column chromatography ( $n$-hexane/EtOAc: $3 / 1)$ yielded $(Z)$-153da $(114 \mathrm{mg}, 66 \%, E / Z=$ $1: 17)$ as a yellow oil.

${ }^{1}$ H-NMR $\left(400 \mathrm{MHz}, \mathrm{CDCl}_{3}\right): \delta=7.66-7.63(\mathrm{~m}, 1 \mathrm{H}), 7.52-7.48(\mathrm{~m}, 1 \mathrm{H}), 7.24-7.19(\mathrm{~m}, 1 \mathrm{H}), 6.97$ $(\mathrm{m}, 2 \mathrm{H}), 6.38(\mathrm{~m}, 1 \mathrm{H}), 5.45-5.32(\mathrm{~m}, 2 \mathrm{H}), 3.66(\mathrm{~s}, 6 \mathrm{H}), 3.32(\mathrm{ddd}, J=7.6,7.5,1.4 \mathrm{~Hz}, 1 \mathrm{H}), 3.26(\mathrm{~d}$, $J=6.4 \mathrm{~Hz}, 1.89 \mathrm{H}, Z), 3.14(\mathrm{~d}, J=6.4 \mathrm{~Hz}, 0.11 \mathrm{H}, E), 2.57-2.52(\mathrm{~m}, 2 \mathrm{H})$.

${ }^{13}$ C-NMR $\left(75 \mathrm{MHz}, \mathrm{CDCl}_{3}\right): \delta=169.0\left(\mathrm{C}_{\mathrm{q}}\right), 162.2\left(\mathrm{C}_{\mathrm{q}},{ }^{1} J_{\mathrm{C}-\mathrm{F}}=248.2 \mathrm{~Hz}\right), 140.4(\mathrm{CH}), 139.2\left(\mathrm{C}_{\mathrm{q}}\right.$, $\left.{ }^{3} J_{\mathrm{C}-\mathrm{F}}=8.0 \mathrm{~Hz}\right), 135.6\left(\mathrm{C}_{\mathrm{q}},{ }^{4} J_{\mathrm{C}-\mathrm{F}}=3.1 \mathrm{~Hz}\right), 130.8(\mathrm{CH}), 129.4(\mathrm{CH}), 128.1\left(\mathrm{CH},{ }^{3} J_{\mathrm{C}-\mathrm{F}}=9.0 \mathrm{~Hz}\right)$, $126.7(\mathrm{CH}), 116.5\left(\mathrm{CH},{ }^{2} J_{\mathrm{C}-\mathrm{F}}=23.0 \mathrm{~Hz}\right), 113.5\left(\mathrm{CH},{ }^{2} J_{\mathrm{C}-\mathrm{F}}=22.7 \mathrm{~Hz}\right), 106.3(\mathrm{CH}), 52.4\left(\mathrm{CH}_{3}\right), 51.2$ $(\mathrm{CH}), 34.0\left(\mathrm{CH}_{2},{ }^{4} J_{\mathrm{C}-\mathrm{F}}=1.5 \mathrm{~Hz}, E\right), 31.3\left(\mathrm{CH}_{2}, E\right), 28.8\left(\mathrm{CH}_{2},{ }^{4} J_{\mathrm{C}-\mathrm{F}}=1.5 \mathrm{~Hz}, Z\right), 26.5\left(\mathrm{CH}_{2}, Z\right)$.

${ }^{19}$ F-NMR $\left(282 \mathrm{MHz}, \mathrm{CDCl}_{3}\right): \delta=-112.7(E),-112.5(Z)$. IR (ATR): 1731, 1518, 1497, 1434, 1267 , $1230,1150,1024,755 \mathrm{~cm}^{-1}$. 
MS (ESI) $m / z$ (relative intensity): $369(30)[\mathrm{M}+\mathrm{Na}]^{+}, 347(100)[\mathrm{M}+\mathrm{H}]^{+}$.

HR-MS (ESI) $m / z$ calcd. for $\mathrm{C}_{18} \mathrm{H}_{20} \mathrm{FN}_{2} \mathrm{O}_{4}{ }^{+}[\mathrm{M}+\mathrm{H}]^{+} 347.1402$, found 347.1402.<smiles>CC(=O)C(C/C=C/Cc1cc(F)ccc1-n1cccn1)C(C)=O</smiles>

\section{(E)-Dimethyl 2-\{4-[5-fluoro-2-(1H-pyrazol-1-yl)phenyl]but-2-en-1-yl\}malonate [(E)-153da']:}

The general procedure $\mathbf{G}$ was followed using 1-(4-fluorophenyl)-1H-pyrazole (152d) (41 mg, $0.25 \mathrm{mmol}$ ) and dimethyl 2-vinylcyclopropane-1,1-dicarboxylate (138a) (55.2 $\mathrm{mg}, 0.30 \mathrm{mmol}$ ). Isolation by column chromatography ( $n$-hexane/EtOAc: $3 / 1)$ yielded $(E)$-153da' $(44.2 \mathrm{mg}, 48 \%, E / Z=$ 1:2) as a yellow oil.

${ }^{1}$ H-NMR $\left(300 \mathrm{MHz}, \mathrm{CDCl}_{3}\right): \delta=7.69-7.66(\mathrm{~m}, 1 \mathrm{H}), 7.55-7.50(\mathrm{~m}, 1 \mathrm{H}), 7.33-7.24(\mathrm{~m}, 1 \mathrm{H}), 7.02-$ $6.92(\mathrm{~m}, 2 \mathrm{H}), 6.45-6.38(\mathrm{~m}, 1 \mathrm{H}), 5.55-5.23(\mathrm{~m}, 2 \mathrm{H}), 3.70(\mathrm{~s}, 6 \mathrm{H}), 3.41-3.32(\mathrm{~m}, 1 \mathrm{H}), 3.28(\mathrm{~d}, J=$ $6.4 \mathrm{~Hz}, 1.20 \mathrm{H}, Z), 3.17(\mathrm{~d}, J=6.4 \mathrm{~Hz}, 0.80 \mathrm{H}, E), 2.62-2.52(\mathrm{~m}, 2 \mathrm{H})$.

${ }^{13}$ C-NMR $\left(100 \mathrm{MHz}, \mathrm{CDCl}_{3}\right): \delta=169.0\left(\mathrm{C}_{\mathrm{q}}\right), 162.8\left(\mathrm{C}_{\mathrm{q}},{ }^{1} J_{\mathrm{C}-\mathrm{F}}=248.1 \mathrm{~Hz}\right), 140.4(\mathrm{CH}), 138.9\left(\mathrm{C}_{\mathrm{q}}\right.$, $\left.{ }^{3} J_{\mathrm{C}-\mathrm{F}}=8.0 \mathrm{~Hz}\right), 135.6\left(\mathrm{C}_{\mathrm{q}},{ }^{4} J_{\mathrm{C}-\mathrm{F}}=3.1 \mathrm{~Hz}\right), 130.8(\mathrm{CH}), 129.4(\mathrm{CH}), 128.2\left(\mathrm{CH},{ }^{3} J_{\mathrm{C}-\mathrm{F}}=9.0 \mathrm{~Hz}\right), 126.7$ $(\mathrm{CH}), 116.8\left(\mathrm{CH},{ }^{2} J_{\mathrm{C}-\mathrm{F}}=23.0 \mathrm{~Hz}\right), 113.7\left(\mathrm{CH},{ }^{2} J_{\mathrm{C}-\mathrm{F}}=22.7 \mathrm{~Hz}\right), 106.5(\mathrm{CH}), 52.5\left(\mathrm{CH}_{3}\right), 51.4(\mathrm{CH})$, $34.4\left(\mathrm{CH}_{2},{ }^{4} J_{\mathrm{C}-\mathrm{F}}=1.5 \mathrm{~Hz}, E\right), 31.2\left(\mathrm{CH}_{2}, E\right), 29.0\left(\mathrm{CH}_{2},{ }^{4} J_{\mathrm{C}-\mathrm{F}}=1.5 \mathrm{~Hz}, Z\right), 26.5\left(\mathrm{CH}_{2}, Z\right)$.

${ }^{19}$ F-NMR $\left(282 \mathrm{MHz}, \mathrm{CDCl}_{3}\right): \delta=-112.7(E),-112.5(Z)$. IR (ATR): 1732, 1518, 1497, 1435, 1334, $1268,1151,755 \mathrm{~cm}^{-1}$.

MS (ESI) $m / z$ (relative intensity): $369(20)[\mathrm{M}+\mathrm{Na}]^{+}, 347(100)[\mathrm{M}+\mathrm{H}]^{+}$.

HR-MS (ESI) $m / z$ calcd. for $\mathrm{C}_{18} \mathrm{H}_{19} \mathrm{FNaN}_{2} \mathrm{O}_{4}{ }^{+}[\mathrm{M}+\mathrm{Na}]^{+} 369.1221$, found 369.1221. 
<smiles>CC(=O)C(C/C=C\Cc1cc(C)ccc1-n1cccn1)C(C)=O</smiles>

\section{(Z)-Dimethyl 2-\{4-[5-methyl-2-(1H-pyrazol-1-yl)phenyl]but-2-en-1-yl\}malonat [(Z)-153ea]:}

The general procedure $\mathbf{F}$ was followed using 1-(p-tolyl)- $1 H$-pyrazole (152e) $(79.3 \mathrm{mg}, 0.50 \mathrm{mmol})$ and dimethyl 2-vinylcyclopropane-1,1-dicarboxylate (138a) (110 mg, $0.60 \mathrm{mmol})$. Isolation by column chromatography ( $n$-hexane/EtOAc: $3 / 1)$ yielded $(Z)$-153ea $(118 \mathrm{mg}, 69 \%, E / Z=1: 19)$ as a yellow oil.

${ }^{1}$ H-NMR (400 MHz, $\left.\mathrm{CDCl}_{3}\right): \delta=7.66-7.63(\mathrm{~m}, 1 \mathrm{H}), 7.52-7.48(\mathrm{~m}, 1 \mathrm{H}), 7.13(\mathrm{~d}, J=7.9 \mathrm{~Hz}, 1 \mathrm{H})$, 7.08-7.02 (m, 2H), $6.37(\mathrm{~m}, 1 \mathrm{H}), 5.43(\mathrm{dtt}, J=10.7,7.4,1.4 \mathrm{~Hz}, 1 \mathrm{H}), 5.32(\mathrm{dtt}, J=10.7,7.6,1.4 \mathrm{~Hz}$, $1 \mathrm{H}), 3.66(\mathrm{~s}, 6 \mathrm{H}), 3.32$ (t, $J=7.8 \mathrm{~Hz}, 1 \mathrm{H}), 3.27$ (d, $J=7.4 \mathrm{~Hz}, 1.90 \mathrm{H}, Z), 3.15$ (d, $J=7.3 \mathrm{~Hz}, 0.10 \mathrm{H}$, $E$ ), 2.57 (ddd, $J=7.6,7.6,1.4 \mathrm{~Hz}, 2 \mathrm{H}), 2.33(\mathrm{~s}, 3 \mathrm{H})$.

${ }^{13}$ C-NMR $\left(100 \mathrm{MHz}, \mathrm{CDCl}_{3}\right): \delta=169.1\left(\mathrm{C}_{\mathrm{q}}\right), 140.1(\mathrm{CH}), 138.5\left(\mathrm{C}_{\mathrm{q}}\right), 137.1\left(\mathrm{C}_{\mathrm{q}}\right), 136.0\left(\mathrm{C}_{\mathrm{q}}\right), 130.7$ $(\mathrm{CH}), 130.6(\mathrm{CH}), 130.5(\mathrm{CH}), 127.3(\mathrm{CH}), 126.2(\mathrm{CH}), 125.6(\mathrm{CH}), 106.0(\mathrm{CH}), 52.3\left(\mathrm{CH}_{3}\right), 51.3$ $(\mathrm{CH}), 34.1\left(\mathrm{CH}_{2}, E\right), 31.1\left(\mathrm{CH}_{2}, E\right), 29.0\left(\mathrm{CH}_{2}, \mathrm{Z}\right), 26.5\left(\mathrm{CH}_{2}, \mathrm{Z}\right), 21.0\left(\mathrm{CH}_{3}\right)$.

IR (ATR): 1732, 1518, 1434, 1495, 1231, 1152, 1023, 916, 753, $624 \mathrm{~cm}^{-1}$.

MS (ESI) $m / z$ (relative intensity): $365(10)[\mathrm{M}+\mathrm{Na}]^{+}, 343(100)[\mathrm{M}+\mathrm{H}]^{+}$.

HR-MS (ESI) $m / z$ calcd. for $\mathrm{C}_{19} \mathrm{H}_{23} \mathrm{~N}_{2} \mathrm{O}_{4}{ }^{+}[\mathrm{M}+\mathrm{H}]^{+} 343.1652$, found 343.1655.<smiles>CC(=O)C(C/C=C\Cc1c(F)cccc1-c1ccccn1)C(C)=O</smiles>

(Z)-Dimethyl 2-\{4-[2-fluoro-6-(pyridin-2-yl)phenyl]but-2-en-1-yl\}malonate [(Z)-153fa]:

The general procedure $\mathbf{F}$ was followed using 2-(3-fluorophenyl)pyridine (152f) (42.5 mg, $0.25 \mathrm{mmol}$ ) and dimethyl 2-vinylcyclopropane-1,1-dicarboxylate (138a) (55.2 $\mathrm{mg}, 0.30 \mathrm{mmol})$. Isolation by 
column chromatography ( $n$-hexane/EtOAc: 10/1->7/1->5/1) yielded $(Z)-153 f a(51.8 \mathrm{mg}, 58 \%, E / Z=$ $1: 7)$ and $(Z)$-153fa' $(12.5 \mathrm{mg}, 14 \%, E / Z=1: 5)$ as yellow oils.

${ }^{1} \mathbf{H}-\mathrm{NMR}\left(300 \mathrm{MHz}, \mathrm{CDCl}_{3}\right): \delta=8.69(\mathrm{ddd}, J=4.3,1.6,0.8 \mathrm{~Hz}, 1 \mathrm{H}), 7.79-7.72(\mathrm{~m}, 1 \mathrm{H}), 7.38-7.26$ $(\mathrm{m}, 2 \mathrm{H}), 7.09-6.95(\mathrm{~m}, 3 \mathrm{H}), 5.57(\mathrm{dtt}, J=15.2,7.2,1.4,0.13 \mathrm{H}, E), 5.46(\mathrm{dtt}, J=10.8,7.2,1.4$, $0.87 \mathrm{H}, Z), 5.34-5.16(\mathrm{~m}, 1 \mathrm{H}), 3.69(\mathrm{~s}, 5.20 \mathrm{H}, Z), 3.64(\mathrm{~s}, 0.80 \mathrm{H}, E), 3.51$ (d, J = $7.2 \mathrm{~Hz}, 1.74 \mathrm{H}, Z$ ), $3.38(\mathrm{~d}, J=7.2 \mathrm{~Hz}, 0.26 \mathrm{H}, E), 3.28(\mathrm{t}, J=7.7 \mathrm{~Hz}, 1 \mathrm{H}), 2.49$ (ddd, $J=7.6,7.6,1.4 \mathrm{~Hz}, 2 \mathrm{H})$.

${ }^{13}$ C-NMR $\left(125 \mathrm{MHz}, \mathrm{CDCl}_{3}\right): \delta=169.3\left(\mathrm{C}_{\mathrm{q}}\right), 161.5\left(\mathrm{C}_{\mathrm{q}},{ }^{1} J_{\mathrm{C}-\mathrm{F}}=245.1 \mathrm{~Hz}\right), 158.6\left(\mathrm{C}_{\mathrm{q}},{ }^{4} J_{\mathrm{C}-\mathrm{F}}=3.0\right.$ $\mathrm{Hz}), 149.3(\mathrm{CH}), 142.4\left(\mathrm{C}_{\mathrm{q}},{ }^{3} J_{\mathrm{C}-\mathrm{F}}=3.8 \mathrm{~Hz}\right), 136.5(\mathrm{CH}), 130.5(\mathrm{CH}), 127.4\left(\mathrm{CH},{ }^{3} J_{\mathrm{C}-\mathrm{F}}=9.2 \mathrm{~Hz}\right)$, $126.0\left(\mathrm{C}_{\mathrm{q}},{ }^{2} J_{\mathrm{C}-\mathrm{F}}=17.0 \mathrm{~Hz}\right), 125.5\left(\mathrm{CH},{ }^{4} J_{\mathrm{C}-\mathrm{F}}=3.2 \mathrm{~Hz}\right), 124.8(\mathrm{CH}), 124.2(\mathrm{CH}), 122.1(\mathrm{CH}), 115.3$ $\left(\mathrm{CH},{ }^{2} J_{\mathrm{C}-\mathrm{F}}=22.5 \mathrm{~Hz}\right), 52.5\left(\mathrm{CH}_{3}\right), 51.4(\mathrm{CH}), 31.6\left(\mathrm{CH}_{2}, E\right), 29.0\left(\mathrm{CH}_{2}, E\right), 26.5\left(\mathrm{CH}_{2}, \mathrm{Z}\right), 24.2$ $\left(\mathrm{CH}_{2}, \mathrm{Z}\right)$.

${ }^{19}$ F-NMR $\left(282 \mathrm{MHz}, \mathrm{CDCl}_{3}\right): \delta=-116.4(Z),-116.7(E)$.

IR (ATR): 1732, 1585, 1565, 1471, 1434, 1232, 1194, 1150, $749 \mathrm{~cm}^{-1}$.

MS (ESI) $m / z$ (relative intensity): $380(60)[\mathrm{M}+\mathrm{Na}]^{+}, 358(100)[\mathrm{M}+\mathrm{H}]^{+}$.

HR-MS (ESI) $m / z$ calcd. for $\mathrm{C}_{20} \mathrm{H}_{21} \mathrm{FNO}_{4}{ }^{+}[\mathrm{M}+\mathrm{H}]^{+} 358.1449$, found 358.1450.<smiles>CC(=O)C(C/C=C\Cc1ccc(F)cc1-c1ccccn1)C(C)=O</smiles>

\section{(Z)-Dimethyl 2-\{4-[4-fluoro-2-(pyridin-2-yl)phenyl]but-2-en-1-yl\}malonate [(Z)-153'fa]:}

${ }^{1}$ H-NMR $\left(300 \mathrm{MHz}, \mathrm{CDCl}_{3}\right): \delta=8.67$ (ddd, $\left.J=4.3,1.6,0.8 \mathrm{~Hz}, 1 \mathrm{H}\right), 7.77-7.71(\mathrm{~m}, 1 \mathrm{H}), 7.35(\mathrm{~d}, J$ $=7.8 \mathrm{~Hz}, 1 \mathrm{H}), 7.26(\mathrm{ddd}, J=4.2,2.4,1.4 \mathrm{~Hz}, 1 \mathrm{H}), 7.22(\mathrm{dd}, J=6.2,3.8 \mathrm{~Hz}, 1 \mathrm{H}), 7.16-7.02(\mathrm{~m}, 2 \mathrm{H})$, $5.57(\mathrm{dtt}, J=15.3,7.0,1.2,0.16 \mathrm{H}, E), 5.45(\mathrm{dtt}, J=10.8,7.0,1.2,0.84 \mathrm{H}, Z), 5.27-5.08(\mathrm{~m}, 1 \mathrm{H})$, 3.70 (s, 5.17, Z), 3.65 (s, 0.83H, E), 3.51 (d, $J=7.0 \mathrm{~Hz}, 2 \mathrm{H}), 3.29$ (dd, $J=7.6 \mathrm{~Hz}, 1 \mathrm{H}), 2.48$ (ddd, $J$ $=7.3,7.2,1.2 \mathrm{~Hz}, 2 \mathrm{H})$.

${ }^{13}$ C-NMR $\left(125 \mathrm{MHz}, \mathrm{CDCl}_{3}\right): \delta=169.3\left(\mathrm{C}_{\mathrm{q}}\right), 161.1\left(\mathrm{C}_{\mathrm{q}},{ }^{1} J_{\mathrm{C}-\mathrm{F}}=245.1 \mathrm{~Hz}\right), 158.6\left(\mathrm{C}_{\mathrm{q}},{ }^{4} J_{\mathrm{C}-\mathrm{F}}=4.4\right.$ $\mathrm{Hz}), 149.3(\mathrm{CH}), 141.6\left(\mathrm{C}_{\mathrm{q}},{ }^{3} J_{\mathrm{C}-\mathrm{F}}=4.6 \mathrm{~Hz}\right), 136.6(\mathrm{CH}), 134.0(\mathrm{CH}), 131.6(\mathrm{CH}), 131.2\left(\mathrm{C}_{\mathrm{q}},{ }^{4} J_{\mathrm{C}-\mathrm{F}}=\right.$ 
$7.7 \mathrm{~Hz}), 125.2(\mathrm{CH}), 124.1(\mathrm{CH}), 122.2(\mathrm{CH}), 116.4\left(\mathrm{CH},{ }^{2} J_{\mathrm{C}-\mathrm{F}}=22.3 \mathrm{~Hz}\right), 115.3\left(\mathrm{CH},{ }^{2} J_{\mathrm{C}-\mathrm{F}}=22.3\right.$ $\mathrm{Hz}), 52.5\left(\mathrm{CH}_{3}\right), 51.5(\mathrm{CH}), 35.5\left(\mathrm{CH}_{2}, E\right), 31.7\left(\mathrm{CH}_{2}, E\right), 30.2\left(\mathrm{CH}_{2}, \mathrm{Z}\right), 26.6\left(\mathrm{CH}_{2}, \mathrm{Z}\right)$.

${ }^{19}$ F-NMR $\left(282 \mathrm{MHz}, \mathrm{CDCl}_{3}\right): \delta=-117.3(Z),-117.2(E)$.

IR (ATR): 1735, 1452, 1436, 1372, 1237, 1154, 1045, $778 \mathrm{~cm}^{-1}$.

HR-MS (ESI) $m / z$ calcd. for $\mathrm{C}_{20} \mathrm{H}_{21} \mathrm{FNO}_{4}{ }^{+}\left[\mathrm{M}+\mathrm{H}^{+}\right]$358.1449, found 358.1456.

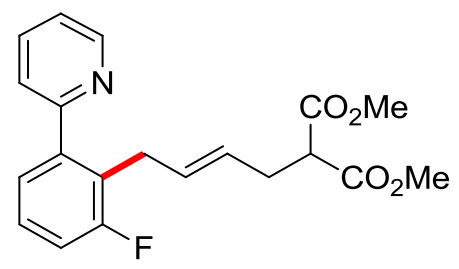

(E,Z)-Dimethyl 2-\{4-[2-fluoro-6-(pyridin-2-yl)phenyl]but-2-en-1-yl\}malonate [(E,Z)-153fa']:

The general procedure $\mathbf{G}$ was followed using 2-(3-fluorophenyl)pyridine (152f) (42.5 mg, $0.25 \mathrm{mmol}$ ) and dimethyl 2-vinylcyclopropane-1,1-dicarboxylate (138a) $(55.2 \mathrm{mg}, 0.30 \mathrm{mmol})$. Isolation by column chromatography ( $n$-hexane/EtOAc: 10/1->7/1->5/1) yielded (E,Z)-153fa' $(21.4 \mathrm{mg}, 24 \%, E / Z$ $=1: 1)$ and $(E, Z)$-153fa" (5.4 mg, 6\%, E/Z = 1:1).

${ }^{1}$ H-NMR $\left(300 \mathrm{MHz}, \mathrm{CDCl}_{3}\right): \delta=8.67$ (ddd, $\left.J=4.3,1.6,0.8 \mathrm{~Hz}, 1 \mathrm{H}\right), 7.77-7.71(\mathrm{~m}, 1 \mathrm{H}), 7.35(\mathrm{~d}, J$ $=7.8 \mathrm{~Hz}, 1 \mathrm{H}), 7.26(\mathrm{ddd}, J=4.2,2.4,1.4 \mathrm{~Hz}, 1 \mathrm{H}), 7.22(\mathrm{dd}, J=6.2,4.2 \mathrm{~Hz}, 1 \mathrm{H}), 7.16-7.02(\mathrm{~m}, 2 \mathrm{H})$, $5.57(\mathrm{dtt}, J=15.2,7.2,1.4,0.53 \mathrm{H}, E), 5.46(\mathrm{dtt}, J=10.8,7.2,1.4,0.47 \mathrm{H}, Z), 5.27-5.08(\mathrm{~m}, 1 \mathrm{H})$, $3.70(\mathrm{~s}, 2.66 \mathrm{H}, Z), 3.64(\mathrm{~s}, 3.34 \mathrm{H}, E), 3.50(\mathrm{~d}, J=7.0 \mathrm{~Hz}, 0.84 \mathrm{H}, Z), 3.38(\mathrm{~d}, J=7.0 \mathrm{~Hz}, 1.16 \mathrm{H}, E)$, $3.33-3.25(\mathrm{~m}, 1 \mathrm{H}), 2.48(\mathrm{ddd}, J=7.6,7.5,1.4 \mathrm{~Hz}, 2 \mathrm{H})$.

${ }^{13}$ C-NMR $\left(125 \mathrm{MHz}, \mathrm{CDCl}_{3}\right): \delta=169.3\left(\mathrm{C}_{\mathrm{q}}\right), 161.4\left(\mathrm{C}_{\mathrm{q}},{ }^{1} J_{\mathrm{C}-\mathrm{F}}=245 \mathrm{~Hz}\right), 158.5\left(\mathrm{C}_{\mathrm{q}},{ }^{4} J_{\mathrm{C}-\mathrm{F}}=3.3 \mathrm{~Hz}\right)$, $149.3(\mathrm{CH}), 142.5\left(\mathrm{C}_{\mathrm{q}},{ }^{3} J_{\mathrm{C}-\mathrm{F}}=3.8 \mathrm{~Hz}\right), 136.5(\mathrm{CH}), 130.5(\mathrm{CH}), 127.4\left(\mathrm{CH},{ }^{3} J_{\mathrm{C}-\mathrm{F}}=9.2 \mathrm{~Hz}\right), 126.0$ $\left(\mathrm{C}_{\mathrm{q}},{ }^{2} J_{\mathrm{C}-\mathrm{F}}=17.2 \mathrm{~Hz}\right), 125.5\left(\mathrm{CH},{ }^{4} J_{\mathrm{C}-\mathrm{F}}=3.2 \mathrm{~Hz}\right), 124.8(\mathrm{CH}), 124.2(\mathrm{CH}), 122.1(\mathrm{CH}), 115.3(\mathrm{CH}$, $\left.{ }^{2} J_{\mathrm{C}-\mathrm{F}}=22.8 \mathrm{~Hz}\right), 52.5\left(\mathrm{CH}_{3}, \mathrm{Z}\right), 52.4\left(\mathrm{CH}_{3}, E\right), 51.8(\mathrm{CH}, E), 51.5(\mathrm{CH}, \mathrm{Z}), 31.8\left(\mathrm{CH}_{2}, E\right), 29.0\left(\mathrm{CH}_{2}\right.$, E), $26.5\left(\mathrm{CH}_{2}, \mathrm{Z}\right), 24.2\left(\mathrm{CH}_{2}, Z\right)$.

${ }^{19}$ F-NMR $\left(282 \mathrm{MHz}, \mathrm{CDCl}_{3}\right): \delta=-116.4(Z),-116.7(E)$.

IR (ATR): 1735, 1452, 1436, 1372, 1237, 1154, 1045, $778 \mathrm{~cm}^{-1}$.

MS (ESI) $\mathrm{m} / z$ (relative intensity): $380(60)[\mathrm{M}+\mathrm{Na}]^{+}, 358(100)[\mathrm{M}+\mathrm{H}]^{+}$.

HR-MS (ESI) $m / z$ calcd. for $\mathrm{C}_{20} \mathrm{H}_{21} \mathrm{FNO}_{4}{ }^{+}\left[\mathrm{M}+\mathrm{H}^{+}\right]$358.1449, found 358.1456. 
<smiles>CC(=O)C(C/C=C\Cc1ccc(F)cc1-c1ccccn1)C(C)=O</smiles>

(E,Z)-Dimethyl 2-\{4-[4-fluoro-2-(pyridin-2-yl)phenyl]but-2-en-1-yl\}malonate [(E,Z)-153fa"]:

${ }^{1}$ H-NMR $\left(300 \mathrm{MHz}, \mathrm{CDCl}_{3}\right): \delta=8.67(\mathrm{ddd}, J=4.3,1.6,0.8 \mathrm{~Hz}, 1 \mathrm{H}), 7.77-7.71(\mathrm{~m}, 1 \mathrm{H}), 7.39-7.32$ $(\mathrm{m}, 1 \mathrm{H}), 7.31-7.27(\mathrm{~m}, 1 \mathrm{H}), 7.25-7.19(\mathrm{~m}, 1 \mathrm{H}), 7.12-6.98(\mathrm{~m}, 2 \mathrm{H}), 5.57(\mathrm{dtt}, J=15.2,7.2,1.4$, $0.50 \mathrm{H}, E), 5.46(\mathrm{dtt}, J=10.8,7.2,1.4,0.50 \mathrm{H}, Z), 5.34-5.21(\mathrm{~m}, 1 \mathrm{H}), 3.71(\mathrm{~s}, 3.00 \mathrm{H}, Z), 3.68$ (s, $3.00 \mathrm{H}, E), 3.47(\mathrm{~d}, J=7.0 \mathrm{~Hz}, 1 \mathrm{H}), 3.38-3.33(\mathrm{~m}, 2 \mathrm{H}), 2.60-2.49(\mathrm{~m}, 2 \mathrm{H})$.

${ }^{13}$ C-NMR $\left(125 \mathrm{MHz}, \mathrm{CDCl}_{3}\right): \delta=169.3\left(\mathrm{C}_{\mathrm{q}}\right), 161.1\left(\mathrm{C}_{\mathrm{q}},{ }^{1} J_{\mathrm{C}-\mathrm{F}}=245.4 \mathrm{~Hz}\right), 158.6\left(\mathrm{C}_{\mathrm{q}},{ }^{4} J_{\mathrm{C}-\mathrm{F}}=4.4\right.$ $\mathrm{Hz}), 149.3(\mathrm{CH}), 141.6\left(\mathrm{C}_{\mathrm{q}},{ }^{3} J_{\mathrm{C}-\mathrm{F}}=4.6 \mathrm{~Hz}\right), 136.6(\mathrm{CH}), 134.0(\mathrm{CH}), 131.6(\mathrm{CH}), 131.2\left(\mathrm{C}_{\mathrm{q}},{ }^{4} J_{\mathrm{C}-\mathrm{F}}=\right.$ $7.7 \mathrm{~Hz}), 125.2(\mathrm{CH}), 124.1(\mathrm{CH}), 122.2(\mathrm{CH}), 116.4\left(\mathrm{CH},{ }^{2} J_{\mathrm{C}-\mathrm{F}}=22.3 \mathrm{~Hz}\right), 115.3\left(\mathrm{CH},{ }^{2} J_{\mathrm{C}-\mathrm{F}}=22.3\right.$ $\mathrm{Hz}), \quad 52.5\left(\mathrm{CH}_{3}\right), 51.5(\mathrm{CH}), 35.5\left(\mathrm{CH}_{2}, E\right), 31.7\left(\mathrm{CH}_{2}, E\right), 30.2\left(\mathrm{CH}_{2}, Z\right), 26.6\left(\mathrm{CH}_{2}, Z\right)$.

${ }^{19} \mathbf{F}-\mathbf{N M R}\left(282 \mathrm{MHz}, \mathrm{CDCl}_{3}\right): \delta=-117.3(Z),-117.2(E)$.

IR (ATR): 1735, 1452, 1436, 1372, 1237, 1154, 1045, $778 \mathrm{~cm}^{-1}$.

HR-MS (ESI) $m / z$ calcd. for $\mathrm{C}_{20} \mathrm{H}_{21} \mathrm{FNO}_{4}{ }^{+}\left[\mathrm{M}+\mathrm{H}^{+}\right]$358.1449, found 358.1456.<smiles>CC(=O)C(C/C=C\Cc1ccc(C=O)n1-c1ccccn1)C(C)=O</smiles>

\section{(Z)-dimethyl 2-(4-(5-formyl-1-(pyridin-2-yl)-1H-pyrrol-2-yl)but-2-en-1-yl)malonate (153ga):}

The representative procedure $\mathbf{F}$ was followed using 1-phenyl-1H-pyrrole-2-carbaldehyde (152g) and dimethyl 2-vinylcyclopropane-1,1-dicarboxylate (138a) (55.2 mg, $0.30 \mathrm{mmol})$. (85 mg, $0.50 \mathrm{mmol})$, Isolation by column chromatography(n-hexane/EtOAc: 10/1->7/1->5/1) yielded (E,Z)-153ga $(138 \mathrm{mg}, 78 \%, Z / E=1: 1)$ as a yellow oil.

${ }^{1}$ H NMR $\left(300 \mathrm{MHz}, \mathrm{CDCl}_{3}\right) \delta=9.39(\mathrm{~s}, 1 \mathrm{H}), 8.60-8.53(\mathrm{~m}, 1 \mathrm{H}), 7.82(\mathrm{tdd}, J=7.6,5.6,1.9 \mathrm{~Hz}, 1 \mathrm{H})$, 7.40-7.33 (m, 1H), 7.32-7.24 (m, 1H), $7.01(\mathrm{~d}, J=3.9 \mathrm{~Hz}, 1 \mathrm{H}), 6.15(\mathrm{dd}, J=6.9,3.9 \mathrm{~Hz}, 1 \mathrm{H}), 5.55-$ 
$5.43(\mathrm{~m}, 1 \mathrm{H}), 5.40-5.30(\mathrm{~m}, 1 \mathrm{H}), 3.67(\mathrm{~s}, 6 \mathrm{H}), 3.39-3.25(\mathrm{~m}, 1 \mathrm{H}), 3.28-3.18(\mathrm{~m}, 2 \mathrm{H}), 2.49(\mathrm{dd}, J=$ $12.5,7.0 \mathrm{~Hz}, 2 \mathrm{H})$.

${ }^{13}$ C NMR $\left(125 \mathrm{MHz}, \mathrm{CDCl}_{3}\right) \delta=177.7(\mathrm{CHO}), 168.9\left(\mathrm{C}_{\mathrm{q}}\right), 150.6\left(\mathrm{C}_{\mathrm{q}}\right), 149.0(\mathrm{CH}), 142.4\left(\mathrm{C}_{\mathrm{q}}\right)$, $138.0(\mathrm{CH}), 132.9\left(\mathrm{C}_{\mathrm{q}}\right), 128.4(\mathrm{CH}), 127.6(\mathrm{CH}), 126.9(\mathrm{CH}), 123.6(\mathrm{CH}), 122.8(\mathrm{CH}), 109.8(\mathrm{CH})$, $52.5\left(\mathrm{CH}_{3}\right), 51.5(\mathrm{CH}), 30.0\left(\mathrm{CH}_{2}\right), 25.0\left(\mathrm{CH}_{2}\right)$.

IR (ATR): 1731, 1517, 1434, 1394, 1271, 1022, 760, $623 \mathrm{~cm}^{-1}$.

HR-MS (ESI) $\mathrm{m} / \mathrm{z}$ calcd for $\mathrm{C}_{19} \mathrm{H}_{21} \mathrm{~N}_{2} \mathrm{O}_{5}{ }^{+}\left[\mathrm{M}+\mathrm{H}^{+}\right] 357.1445$, found 357.1443.

\section{Decarboxylation}

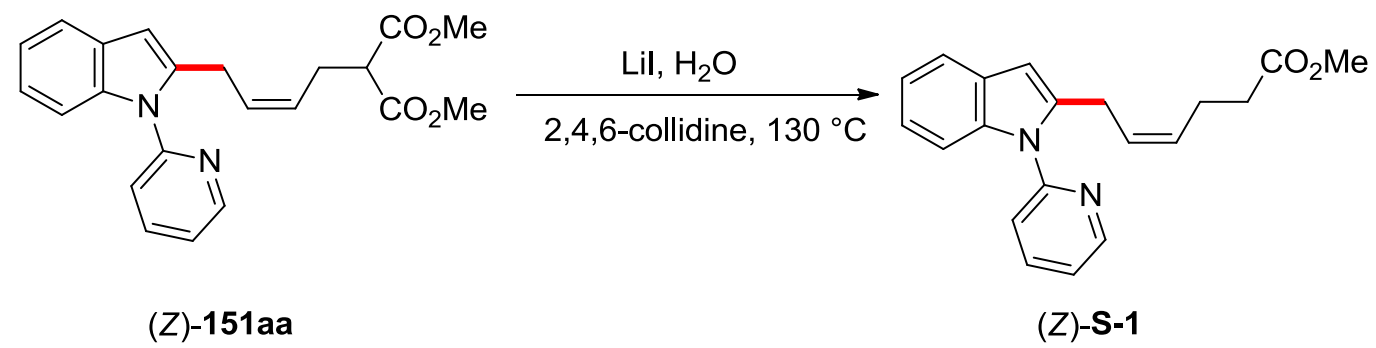

A mixture of dimethyl (Z)-2-\{4-[1-(pyridin-2-yl)-1H-indol-2-yl]but-2-en-1-yl $\}$ malonate (151aa) (113 mg, $300 \mu \mathrm{mol}, 1.0$ equiv), LiI (60.2 mg, $450 \mu \mathrm{mol}, 1.5$ equiv) and $\mathrm{H}_{2} \mathrm{O}$ (10.8 $\mu \mathrm{l}, 600 \mu \mathrm{mol}$, 2.0 equiv) in 2,4,6-collidine $(2.0 \mathrm{~mL}, 0.15 \mathrm{M})$ was stirred at $140{ }^{\circ} \mathrm{C}$ for $24 \mathrm{~h}$. At ambient temperature, the mixture was diluted with EtOAc $(5.0 \mathrm{~mL})$, washed four times successively with $1 \mathrm{M}$ $\mathrm{HCl}(5.0 \mathrm{~mL})$ and sat. $\mathrm{NaHCO}_{3} /$ brine $(1: 3,5.0 \mathrm{~mL})$, dried over $\mathrm{MgSO}_{4}$ and concentrated in vacuo to yield the product $\mathbf{S - 1}$ as a pale yellow liquid (72.0 $\mathrm{mg}, 75 \%)$. 


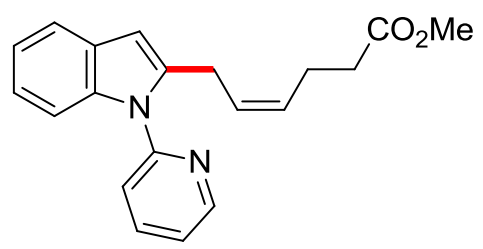

\section{(Z)-Methyl 6-[1-(pyridin-2-yl)-1H-indol-2-yl]hex-4-enoate (S-1):}

${ }^{1}$ H-NMR $\left(300 \mathrm{MHz}, \mathrm{CDCl}_{3}\right): \delta=8.64(\mathrm{ddd}, J=4.9,2.0,0.9 \mathrm{~Hz}, 1 \mathrm{H}), 7.91-7.83(\mathrm{~m}, 1 \mathrm{H}), 7.55(\mathrm{ddd}$, $J=6.0,3.1,0.7 \mathrm{~Hz}, 1 \mathrm{H}), 7.43(\mathrm{ddd}, J=3.9,2.0,1.0 \mathrm{~Hz}, 1 \mathrm{H}), 7.34-7.27(\mathrm{~m}, 2 \mathrm{H}), 7.12-7.07$ (m, 2H), $6.42(\mathrm{~d}, J=1.0 \mathrm{~Hz}, 1 \mathrm{H}), 5.59-5.49(\mathrm{~m}, 1 \mathrm{H}), 5.46-5.34(\mathrm{~m}, 1 \mathrm{H}), 3.65(\mathrm{~s}, 3 \mathrm{H}), 3.64-3.61(\mathrm{~m}, 2 \mathrm{H})$, $2.34-2.29(\mathrm{~m}, 4 \mathrm{H})$.

${ }^{13}$ C-NMR (125 MHz, $\left.\mathrm{CDCl}_{3}\right): \delta=173.3\left(\mathrm{C}_{\mathrm{q}}\right), 151.3\left(\mathrm{C}_{\mathrm{q}}\right), 149.6(\mathrm{CH}), 139.5(\mathrm{CH}), 138.1\left(\mathrm{C}_{\mathrm{q}}\right), 137.3$ $(\mathrm{CH}), 129.2(\mathrm{CH}), 128.5\left(\mathrm{C}_{\mathrm{q}}\right), 127.1(\mathrm{CH}), 121.9(\mathrm{CH}), 121.7(\mathrm{CH}), 121.0(\mathrm{CH}), 120.6(\mathrm{CH}), 119.9$ $(\mathrm{CH}), 110.0\left(\mathrm{C}_{\mathrm{q}}\right), 102.7(\mathrm{CH}), 51.6\left(\mathrm{CH}_{2}\right), 34.0\left(\mathrm{CH}_{2}\right), 26.0\left(\mathrm{CH}_{3}\right), 22.8\left(\mathrm{CH}_{2}\right)$.

IR (ATR): 1733, 1586, 1469, 1455, 1435, 1151, 1024, 972, $747 \mathrm{~cm}^{-1}$.

MS (ESI) $m / z$ (relative intensity): $321(20)[\mathrm{M}+\mathrm{H}]^{+}$.

HR-MS (ESI) $m / z$ calcd. for $\mathrm{C}_{20} \mathrm{H}_{21} \mathrm{~N}_{2} \mathrm{O}_{2}{ }^{+}[\mathrm{M}+\mathrm{H}]^{+} 321.1598$, found 321.1598.

\section{Hydrogenation}

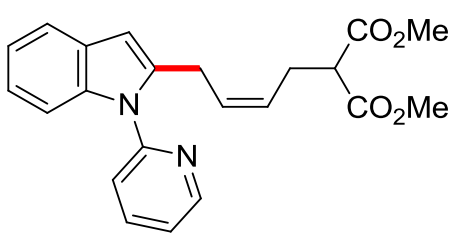

(Z)-151aa

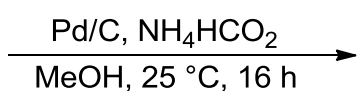

$\mathrm{MeOH}, 25^{\circ} \mathrm{C}, 16 \mathrm{~h}$

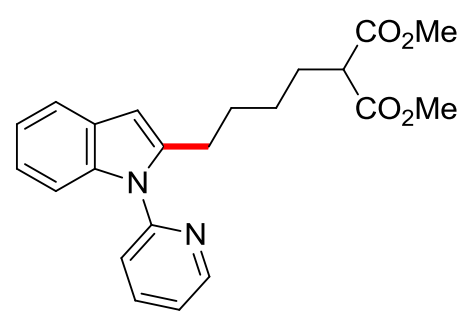

S-2

To a solution of dimethyl (Z)-2-\{4-[1-(pyridin-2-yl)-1H-indol-2-yl]but-2-en-1-yl\}malonate [(Z)-151aa] $(94.5 \mathrm{mg}, 0.25 \mathrm{mmol})$ in $\mathrm{MeOH}(1.0 \mathrm{~mL})$ was added $\mathrm{Pd} / \mathrm{C}(9.5 \mathrm{mg}, 10$ wt.-\%) and ammonium formate (79.0 mg, 5.0 equiv). The mixture was stirred at $25{ }^{\circ} \mathrm{C}$ for $20 \mathrm{~h}$ and then filtered through a short pad of celite. The residue was washed with EtOAc $(10 \mathrm{~mL})$, filtered and the combined 
filtrate was concentrated in vacuo. The crude mixture was purified by flash column chromatography on silica gel ( $n$-hexane/EtOAc: $5 / 1)$ to yield S-2 (88.4 mg, 93\%) as a yellow oil.

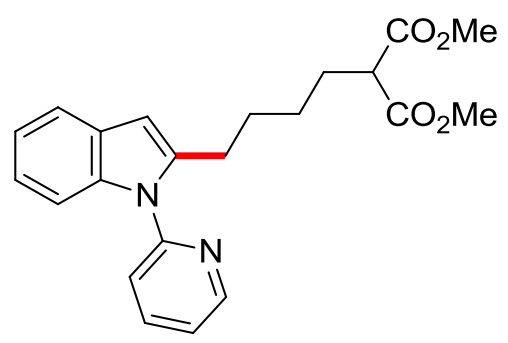

\section{Dimethyl 2-\{4-[1-(pyridin-2-yl)-1H-indol-2-yl]butyl\}malonate (S-2):}

${ }^{1}$ H-NMR $\left(500 \mathrm{MHz}, \mathrm{CDCl}_{3}\right): \delta=8.66(\mathrm{ddd}, J=4.9,1.9,0.7 \mathrm{~Hz}, 1 \mathrm{H}), 7.89(\mathrm{dt}, J=7.8,2.0 \mathrm{~Hz}, 1 \mathrm{H})$, $7.58-7.56(\mathrm{~m}, 1 \mathrm{H}), 7.43(\mathrm{~d}, J=8.0 \mathrm{~Hz}, 1 \mathrm{H}), 7.34-7.31(\mathrm{~m}, 2 \mathrm{H}), 7.14-7.11(\mathrm{~m}, 2 \mathrm{H}), 6.44(\mathrm{~d}, J=0.6$ $\mathrm{Hz}, 1 \mathrm{H}), 3.71(\mathrm{~s}, 6 \mathrm{H}), 3.31(\mathrm{t}, J=7.7 \mathrm{~Hz}, 1 \mathrm{H}), 2.85(\mathrm{ddd}, J=7.6,7.5,1.0 \mathrm{~Hz}, 2 \mathrm{H}), 1.91-1.84(\mathrm{~m}, 2 \mathrm{H})$, 1.64-1.57 (m, 2H), 1.37-1.30 (m, 2H).

${ }^{13}$ C-NMR $\left(125 \mathrm{MHz}, \mathrm{CDCl}_{3}\right): \delta=169.9\left(\mathrm{C}_{\mathrm{q}}\right), 151.5\left(\mathrm{C}_{\mathrm{q}}\right), 149.7(\mathrm{CH}), 141.1\left(\mathrm{C}_{\mathrm{q}}\right), 138.3(\mathrm{CH}), 137.3$ $\left(\mathrm{C}_{\mathrm{q}}\right), 128.6\left(\mathrm{C}_{\mathrm{q}}\right), 122.1(\mathrm{CH}), 121.7(\mathrm{CH}), 121.1(\mathrm{CH}), 120.6(\mathrm{CH}), 119.9(\mathrm{CH}), 110.1(\mathrm{CH}), 102.2$ $(\mathrm{CH}), 52.5\left(\mathrm{CH}_{3}\right), 51.6(\mathrm{CH}), 28.6\left(\mathrm{CH}_{2}\right), 28.1\left(\mathrm{CH}_{2}\right), 27.2\left(\mathrm{CH}_{2}\right), 26.9\left(\mathrm{CH}_{2}\right)$.

IR (ATR): 1731, 1570, 1469, 1435, 1148, 909, 781, $731 \mathrm{~cm}^{-1}$.

MS (ESI) $m / z$ (relative intensity): $403(100)[\mathrm{M}+\mathrm{Na}]^{+}, 381(20)[\mathrm{M}+\mathrm{H}]^{+}$.

HR-MS (ESI) $m / z$ calcd. for $\mathrm{C}_{22} \mathrm{H}_{25} \mathrm{~N}_{2} \mathrm{O}_{4}{ }^{+}[\mathrm{M}+\mathrm{H}]^{+} 381.1809$, found 381.1810.

\section{Isomerization Experiments}

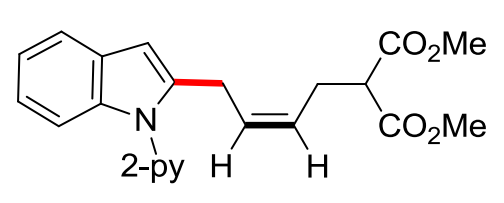

$(Z)-151$ aa $(E / Z=1: 11)$

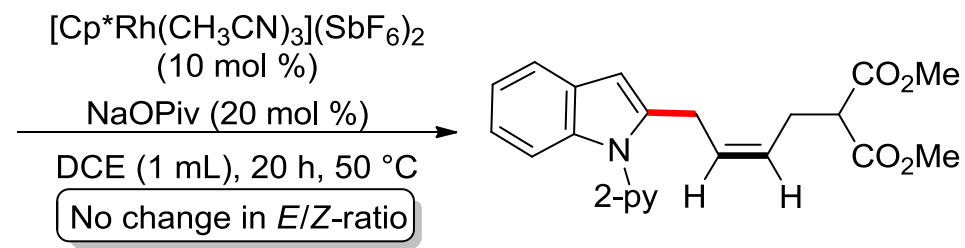

$(Z)-151$ aa $(E / Z=1: 11): 89 \%$

A solution of (Z)-151aa $\left(94.5 \mathrm{mg}, 0.25 \mathrm{mmol}, 1.0\right.$ equiv), $\left[\mathrm{Cp} * \mathrm{Rh}\left(\mathrm{CH}_{3} \mathrm{CN}\right)_{3}\right]\left(\mathrm{SbF}_{6}\right)_{2}(20.0 \mathrm{mg}$, $10 \mathrm{~mol} \%)$ and NaOPiv (6.2 mg, $20 \mathrm{~mol} \%)$ in DCE (1 mL, $0.25 \mathrm{M})$ was stirred at $50{ }^{\circ} \mathrm{C}$ for $20 \mathrm{~h}$. At 
ambient temperature, the solvent was removed and the crude mixture was purified by flash column chromatography on silica gel ( $n$-hexane/EtOAc: $3 / 1)$ to yield $(Z)$-151aa $(84.1 \mathrm{mg}, 89 \%, E / Z=1: 11)$ as a pale yellow oil.

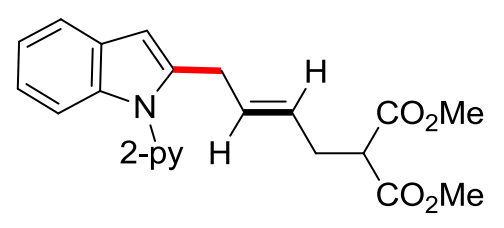

$(E)-151$ aa' $(E / Z=1.8: 1)$
$\left[\mathrm{Cp}{ }^{*} \mathrm{Co}(\mathrm{CO}) \mathrm{I}_{2}\right](10 \mathrm{~mol} \%)$

NaOPiv $(20 \mathrm{~mol} \%)$

DCE $(1 \mathrm{~mL}), 20 \mathrm{~h}, 50^{\circ} \mathrm{C}$

No change in E/Z-ratio

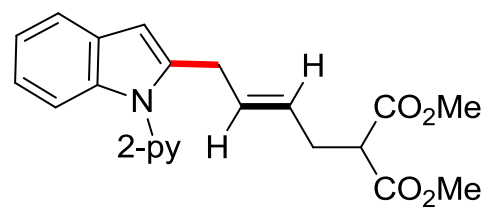

$94 \%,(E)-151 a^{\prime}(E / Z=1.8: 1)$

A solution of $(E)$-151aa' (94.5 mg, $0.25 \mathrm{mmol}, 1.0$ equiv), [Cp*Co(CO) $\left.\mathrm{I}_{2}\right](11.9 \mathrm{mg}, 10 \mathrm{~mol} \%)$ and NaOPiv $(6.2 \mathrm{mg}, 20 \mathrm{~mol} \%)$ in DCE $(1 \mathrm{~mL}, 0.25 \mathrm{M})$ was stirred at $50{ }^{\circ} \mathrm{C}$ for $20 \mathrm{~h}$. At ambient temperature, the solvent was removed and the crude mixture was purified by flash column chromatography on silica gel ( $n$-hexane/EtOAc: 3/1), yielding $(E)$-151aa' $(88.9 \mathrm{mg}, 94 \%, E / Z=1.8: 1)$ as a yellow oil.

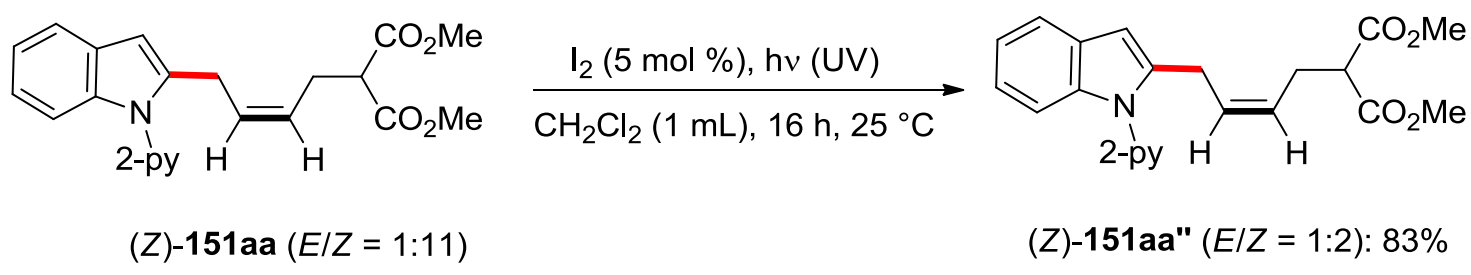

A solution of (Z)-151aa (94.5 mg, $0.25 \mathrm{mmol}, 1.0$ equiv) and $\mathrm{I}_{2}(1.6 \mathrm{mg}, 5 \mathrm{~mol} \%)$ in $\mathrm{CH}_{2} \mathrm{Cl}_{2}(1 \mathrm{~mL}$, $0.25 \mathrm{M})$ was irradiated by UV-light $(254 \mathrm{~nm})$ at $25{ }^{\circ} \mathrm{C}$ for $16 \mathrm{~h}$. The solvent was removed and the crude mixture was purified by column chromatography on silica gel ( $n$-hexane/EtOAc: $5 / 1)$ to yield (Z)-151aa" (78.4 mg, 83\%, $E / Z=1: 2)$ as a yellow oil. 


\section{References}

[1] a) A. Mishra, C.-Q. Ma, P. Bäuerle, Chem. Rev. 2009, 109, 1141-1276; b) J. Kim, Movassaghi, Chem. Soc. Rev. 2009, 38, 3035-3050; c) M. E. Webb, A. Marquet, R. R. Mendel, F. Rebeille, A. G. Smith, Nat. Prod. Rep. 2007, 24, 988-1008; d) M. C. Bagley, J. W. Dale, E. A. Merritt, X. Xiong, Chem. Rev. 2005, 105, 685-714.

[2] a) R. Jana, T. P. Pathak, M. S. Sigman, Chem. Rev. 2011, 111, 1417-1492; b) J.-P. Corbet, G. Mignani, Chem. Rev. 2006, 106, 2651-2710; c) J. F. Hartwig, Angew. Chem. Int. Ed. 1998, 37, 2046-2067.

[3] R. F. Heck, J. P. Nolley, J. Org. Chem. 1972, 37, 2320-2322.

[4] S. Baba, E. Negishi, J. Am. Chem. Soc. 1976, 98, 6729-6731.

[5] a) N. Miyaura, K. Yamada, A. Suzuki, Tetrahedron Lett. 1979, 20, 3437-3440; b) N. Miyaura, A. Suzuki, Chem. Commun. 1979, 866-867.

[6] a) S. H. Cho, J. Y. Kim, J. Kwak, S. Chang, Chem. Soc. Rev. 2011, 40, 5068-5083; b) T. W. Lyons, M. S. Sanford, Chem. Rev. 2010, 110, 1147-1169.

[7] a) L. Ackermann, Acc. Chem. Res. 2014, 47, 281-295; b) S. I. Kozhushkov, L. Ackermann, Chem. Sci. 2013, 4, 886-896; c) P. B. Arockiam, C. Bruneau, P. H. Dixneuf, Chem. Rev. 2012, 112, 5879-5918.

[8] a) G. Song, F. Wang, X. Li, Chem. Soc. Rev. 2012, 41, 3651-3678; b) D. A. Colby, A. S. Tsai, R. G. Bergman, J. A. Ellman, Acc. Chem. Res. 2011, 45, 814-825; c) D. A. Colby, R. G. Bergman, J. A. Ellman, Chem. Rev. 2009, 110, 624-655.

[9] a) H.-Q. Do, O. Daugulis, J. Am. Chem. Soc. 2008, 130, 1128-1129; b) H.-Q. Do, O. Daugulis, J. Am. Chem. Soc. 2007, 129, 12404-12405.

[10] a) T. Kang, Y. Kim, D. Lee, Z. Wang, S. Chang, J. Am. Chem. Soc. 2014, 136, 4141-4144; b) E. M. Simmons, J. F. Hartwig, J. Am. Chem. Soc. 2010, 132, 17092-17095.

[11] a) Y. Hu, B. Zhou, C. Wang, Acc. Chem. Res., 2018, 51, 816-827. b) W. Liu, L. Ackermann, ACS Catal. 2016, 6, 3743-3752; 
[12] a) M. Moselage, J. Li, L. Ackermann, ACS Catal. 2015, 6, 498-525; b) K. Gao, N. Yoshikai, Acc. Chem. Res. 2014, 47, 1208-1219; c) C.-L. Sun, B. Li, Z. Shi, Chem. Rev. 2010, 111, $1293-1314$.

[13] a) D. Alberico, M. E. Scott, M. Lautens, Chem. Rev. 2007, 107, 174-238; b) I. V. Seregin, V. Gevorgyan, Chem. Soc. Rev. 2007, 36, 1173-1193.

[14] a) T. W. Lyons, M. S. Sanford, Chem. Rev. 2010, 110, 1147-1169; b) L. Ackermann, R. Vicente, A. R. Kapdi, Angew. Chem. Int. Ed. 2009, 48, 9792-9826.

[15] a) J. Le Bras, J. Muzart, Chem. Rev. 2011, 111, 1170-1214; b) C. Liu, H. Zhang, W. Shi, A. Lei, Chem. Rev. 2011, 111, 1780-1824; c) G. P. McGlacken, L. M. Bateman, Chem. Soc. Rev. 2009, 38, 2447-2464.

[16] L. Ackermann, Top. Organoment. Chem., 2007, 24, 35-60.

[17] a) F. Xie, Z. Qi, S. Yu, X. Li, J. Am. Chem. Soc. 2014, 136, 4780-4787; b) M. Shang, S.-H. Zeng, S.-Z. Sun, H.-X. Dai, J.-Q. Yu, Org. Lett. 2013, 15, 5286-5289; c) D.-H. Wang, M. Wasa, R. Giri, J.-Q. Yu, J. Am. Chem. Soc. 2008, 130, 7190-7191.

[18] a) Y. Huang, D. Wu, J. Huang, Q. Guo, J. Li, J. You, Angew. Chem., Int. Ed. 2014, 126, 12354-12358; b) R. Manikandan, M. Jeganmohan, Org. Lett. 2014, 16, 3568-3571; c) L. Ackermann, S. Fenner, Org. Lett. 2011, 13, 6548-6551.

[19] a) K. Gao, N. Yoshikai, J. Am. Chem. Soc. 2013, 135, 9279-9282; b) P. Zhao, F. Wang, K. Han, X. Li, Org. Lett. 2012, 14, 5506-5509; c) N. Guimond, K. Fagnou, J. Am. Chem. Soc. 2009, 131, 12050-12051.

[20] a) L. Liang, S. Fu, D. Lin, X.-Q. Zhang, Y. Deng, H. Jiang, W. Zeng, J. Org. Chem. 2014, 79, 9472-9480; b) L. Ackermann, L. Wang, A. V. Lygin, Chem. Sci. 2012, 3, 177-180.

[21] a) K. N. Y. Phani, B. Alexander, R. Keshav, L. Ackermann, Angew. Chem. Int. Ed. 2016, 55, 6929-6932; b) M. Shimizu, K. Hirano, T. Satoh, M. Miura, J. Org. Chem. 2009, 74, $3478-3483$.

[22] a) S. H. Park, J. Y. Kim, S. Chang, Org. Lett. 2011, 13, 2372-2375; b) N. M. Neisius, B. Plietker, Angew. Chem. Int. Ed. 2009, 48, 5752-5755.

[23] a) K. Padala, M. Jeganmohan, Org. Lett. 2012, 14, 1134-1137; b) K. Tanaka, Y. Otake, A. Wada, K. Noguchi, M. Hirano, Org. Lett. 2007, 9, 2203-2206. 
[24] a) S. Tetsuya, N. Yuko, M. Masahiro, N. Masakatsu, Chem. Lett. 1999, 28, 615-616; b) T. Satoh, Y. Kawamura, M. Miura, M. Nomura, Angew. Chem. Int. Ed. Engl. 1997, 36, $1740-1742$.

[25] J.-R. Pouliot, F. Grenier, J. T. Blaskovits, S. Beaupré, M. Leclerc, Chem. Rev. 2016, 116, $14225-14274$.

[26] a) M. Fujita, T. Hiyama, J. Org. Chem. 1988, 53, 5415-5421; b) T. Hiyama, M. Obayashi, I. Mori, H. Nozaki, J. Org. Chem. 1983, 48, 912-914.

[27] C. Jun, Chem. Soc. Rev. 2004, 33, 610-618.

[28] F. C. Kakiuchi, N. Chatani, In Ruthenium catalysts and fine chemistry, Vol. 11, Springer: Heidelberg, Germany, 2004.

[29] a) V. S. Thirunavukkarasu, S. I. Kozhushkov, L. Ackermann, Chem. Commun. 2014, 50, 29-39; b) C. Kornhaaß, J. Li, L. Ackermann, J. Org. Chem 2012, 77, 9190-9198.

[30] S. Oi, S. Fukita, N. Hirata, N. Watanuki, S. Miyano, Y. Inoue, Org. Lett. 2001, 3, 2579-2581.

[31] a) L. Ackermann, Org. Process Res. Dev. 2015, 19, 260-269; b) S. De Sarkar, W. Liu, S. I. Kozhushkov, L. Ackermann, Adv. Synth. Catal. 2014, 356, 1461-1479.

[32] L. Ackermann, R. Vicente, A. Althammer, Org. Lett. 2008, 10, 2299-2302.

[33] a) M. M. Grutters, C. Müller, D. Vogt, J. Am. Chem. Soc. 2006, 128, 7414-7415; b) A. Hirao, S. Loykulnant, T. Ishizone, Prog. Polym. Sci. 2002, 27, 1399-1471.

[34] Y. Fujiwara, I. Moritani, M. Matsuda, S. Teranishi, Tetrahedron Lett. 1968, 9, 3863-3865.

[35] S. I. Kozhushkov, L. Ackermann, Chem. Sci. 2013, 4, 886-896.

[36] H. Weissman, X. Song, D. Milstein, J. Am. Chem. Soc. 2001, 123, 337-338.

[37] E. J. Farrington, J. M. Brown, C. F. J. Barnard, E. Rowsell, Angew. Chem. Int. Ed. 2002, 41, $169-171$.

[38] K.-H. Kwon, D. W. Lee, C. S. Yi, Organometallics 2010, 29, 5748-5750.

[39] L. Ackermann, J. Pospech, Org. Lett. 2011, 13, 4153-4155.

[40] a) K. Ueura, T. Satoh, M. Miura, Org. Lett. 2007, 9, 1407-1409. b) K. Ueura, T. Satoh, M. Miura, J. Org. Chem. 2007, 72, 5362-5367; c) S. Mochida, K. Hirano, T. Satoh, M Miura, J. Org. Chem. 2011, 76, 3024-3033.

[41] L. Ackermann, L. Wang, R. Wolfram, A. V. Lygin, Org. Lett. 2012, 14, 728-731.

[42] K. Graczyk, W. Ma, L. Ackermann, Org. Lett. 2012, 14, 4110-4113.

[43] K. Padala, M. Jeganmohan, Org. Lett. 2012, 14, 1134-1137. 
[44] J. Li, Kornh $\beta$, L. Ackermann, Chem. Commun 2012, 48, 11343-11345.

[45] W. Ma, L. Ackermann, Chem-Eur. J. 2013, 19, 13925-13928.

[46] P. B. Arockiam, C. Fischmeister, C. Bruneau, P. H. Dixneuf, Green Chem. 2011, 13, 3075-3078.

[47] Y. Hashimoto, T. Ueyama, T. Fukutani, K. Hirano, T. Satoh, M. Miura, Chem. Lett. 2011, 40, $1165-1166$.

[48] Y. Hashimoto, T. Ortloff, K. Hirano, T. Satoh, C. Bolm, M. Miura, Chem. Lett. 2012, 41, $151-153$.

[49] C. Tirler, L. Ackermann, Tetrahedron 2015, 71, 4543-4551.

[50] W. Ma, R. Mei, G. Tenti, L. Ackermann, Chem. Eur. J. 2014, 20, 15248-15251.

[51] S. Chiharu, M. Keisuke, H. Koji, S. Tetsuya, M. Masahiro, Adv. Synth. Catal. 2014, 356, $1521-1526$.

[52] a) D. J. Burns, S. I. Kozhushkov, L. Ackermann, in Catalytic Hydroarylation of Carbon-Carbon Multiple Bonds (Eds.: L. G. Habgood, T. B. Gunnoe, L. Ackermann), Wiley-VCH, Weinheim, 2017, pp. 49-81. b) H. Miura, S. Terajima, K. Tsutsui, T. Shishido, J. Org. Chem. 2017, 82, 1231-1239; c) Y. Hashimoto, K. Hirano, T. Satoh, F. Kakiuchi, M. Miura, Org. Lett. 2012, 14, 2058-2061.

[53] L. N. Lewis, J. F. Smith, J. Am. Chem. Soc. 1986, 108, 2728-2735.

[54] S. Murai, F. Kakiuchi, S. Sekine, Y. Tanaka, A. Kamatani, M. Sonoda, N. Chatani, Nature 1993, 366, 529.

[55] F. Kakiuchi, Y. Yamamoto, N. Chatani, S. Murai, Chem. Lett. 1995, 24, 681-682.

[56] K. Cheng, B. Yao, J. Zhao, Y. Zhang, Org. Lett. 2008, 10, 5309-5312.

[57] a) R. N. P. Tulichala, M. Shankar, K. C. K. Swamy, J. Org. Chem. 2017, 82, 5068-5079; b) Y. Hashimoto, K. Hirano, T. Satoh, F. Kakiuchi, M. Miura, J. Org. Chem. 2013, 78, 638-646.

[58] P. Zhao, R. Niu, F. Wang, K. Han, X. Li, Org. Lett. 2012, 14, 4166-4169.

[59] M. Reddy, M. Jeganmohan, Chem. Commun. 2013, 49, 481-483.

[60] a) K. Padala, M. Jeganmohan, Chem. Commun. 2014, 50, 14573-14576; b) C. Suzuki, K. Hirano, T. Satoh, M. Miura, Org. Lett. 2013, 15, 3990-3993.

[61] a) X. Yang, G. Shan, Y. Rao, Org. Lett. 2013, 15, 2334-2337; b) V. S. Thirunavukkarasu, L. Ackermann, Org. Lett. 2012, 14, 6206-6209. 
[62] E. McNeill, J. Du Bois, J. Am. Chem. Soc. 2010, 132, 10202-10204.

[63] Y. Yang, Y. Lin, Y. Rao, Org. Lett. 2012, 14, 2874-2877.

[64] W. Liu, L. Ackermann, Org. Lett. 2013, 15, 3484-3486.

[65] F. Yang, K. Rauch, K. Kettelhoit, L. Ackermann, Angew. Chem. Int. Ed. 2014, 53, $11285-11288$.

[66] a) M. Moselage, J. Li, L. Ackermann, ACS Catal. 2016, 6, 498-525; b) L. Ackermann, J. Org. Chem. 2014, 79, 8948-8954; c) G. Halbritter, F. Knoch, A. Wolski, H. Kisch, Angew. Chem. Int. Ed. 1994, 33, 1603-1605.

[67] S. Murahashi, J. Am. Chem. Soc. 1955, 77, 6403-6404.

[68] S. Murahashi, S. Horiie, J. Am. Chem. Soc. 1956, 78, 4816-4817.

[69] H.-F. Klein, M. Helwig, U. Koch, U. Flörke, H.-J. Haupt, Z. Naturforsch. B: J. Chem. Sci. 1993, 48, 778-784.

[70] P.-S. Lee, T. Fujita, N. Yoshikai, J. Am. Chem. Soc. 2011, 133, 17283-17295.

[71] B. J. Fallon, E. Derat, M. Amatore, C. Aubert, F. Chemla, F. Ferreira, A. Perez-Luna, M. Petit, J. Am. Chem. Soc. 2015, 137, 2448-2451.

[72] K. Gao, N. Yoshikai, J. Am. Chem. Soc. 2011, 133, 400-402.

[73] a) L. Ackermann, Chem. Commun. 2010, 46, 4866-4877. b) L. Ackermann, P. Novák, R. Vicente, N. Hofmann, Angew. Chem. Int. Ed. 2009, 48, 6045-6048.

[74] Q. Chen, L. Ilies, E. Nakamura, J. Am. Chem. Soc. 2011, 133, 428-429.

[75] W. Song, L. Ackermann, Angew. Chem. Int. Ed. 2012, 51, 8251-8254.

[76] K. Gao, P.-S. Lee, C. Long, N. Yoshikai, Org. Lett. 2012, 14, 4234-4237.

[77] M. Marc, S. Nicolas, R. S. C., A. Lutz, Angew. Chem. Int. Ed. 2015, 54, 6352-6355.

[78] T.-J. Gong, B. Xiao, Z.-J. Liu, J. Wan, J. Xu, D.-F. Luo, Y. Fu, L. Liu, Org. Lett. 2011, 13, $3235-3237$.

[79] T. Yoshino, H. Ikemoto, S. Matsunaga, M. Kanai, Angew. Chem. Int. Ed. 2013, 52, $2207-2211$

[80] H. Ikemoto, T. Yoshino, K. Sakata, S. Matsunaga, M. Kanai, J. Am. Chem. Soc. 2014, 136, $5424-5431$

[81] J. R. Hummel, J. A. Ellman, J. Am. Chem. Soc. 2015, 137, 490-498. 
[82] a) L. Kong, S. Yu, X. Zhou, X. Li, Org. Lett. 2016, 18, 588-591; b) Q. Lu, S. Vásquez-Céspedes, T. Gensch, F. Glorius, ACS Catal. 2016, 6, 2352-2356; c) Q. Yan, Z. Chen, Z. Liu, Y. Zhang, Org. Chem. Front. 2016, 3, 678-682.

[83] a) S. Bo, Y. Tatsuhiko, K. Motomu, M. Shigeki, Angew. Chem. Int. Ed. 2015, 54, 12968-12972; b) H. Wang, J. Koeller, W. Liu, L. Ackermann, Chem. Eur. J. 2015, 21, $15525-15528$.

[84] a) L. Kong, X. Yang, X. Zhou, S. Yu, X. Li, Org. Chem. Front. 2016, 3, 813-816; b) W. Yu, W. Zhang, Z. Liu, Y. Zhang, Chem. Commun. 2016, 52, 6837-6840.

[85] H. Wang, M. Moselage, M. J. González, L. Ackermann, ACS Catal. 2016, 6, 2705-2709.

[86] W. Li, L.-H. Weng, G.-X. Jin, Inorg. Chem. Commun. 2004, 7, 1174-1177.

[87] S. Bo, Y. Tatsuhiko, M. Shigeki, K. Motomu, Adv. Synth. Catal. 2014, 356, 1491-1495.

[88] J. Li, L. Ackermann, Angew. Chem. Int. Ed. 2015, 54, 3635-3638.

[89] D.-G. Yu, T. Gensch, F. de Azambuja, S. Vásquez-Céspedes, F. Glorius, J. Am. Chem. Soc. 2014, 136, 17722-17725.

[90] J. Li, L. Ackermann, Angew. Chem. Int. Ed. 2015, 54, 8551-8554.

[91] a) M. K. Manzo-Valencia, L. Valdés-Santiago, L. Sánchez-Segura, D. L. Guzmán-de-Peña, J. Agric. Food. Chem. 2016, 64, 8315-8323; b) E. F. S. Authority, EFSA Journal 2011, 9, 2020; c) V. Martınez, M. Maguregui, R. Jiménez, R. Alonso, J. Pharm. Biomed. Anal. 2000, 23, 459-468.

[92] a) W. Liu, L. Ackermann, Chem. Commun. 2014, 50, 1878-1881; b) L. Wang, L. Ackermann, Chem. Commun. 2014, 50, 1083-1085; c) R. K. Chinnagolla, M. Jeganmohan, Org. Lett. 2012, 14, 5246-5249; d) V. S. Thirunavukkarasu, J. Hubrich, L. Ackermann, Org. Lett. 2012, $14,4210-4213$.

[93] a) G. Li, L. Wan, G. Zhang, D. Leow, J. Spangler, J.-Q. Yu, J. Am. Chem. Soc. 2015, 137, 4391-4397; b) P.-X. Shen, X.-C. Wang, P. Wang, R.-Y. Zhu, J.-Q. Yu, J. Am. Chem. Soc. 2015, 137, 11574-11577; c) A. Deb, S. Bag, R. Kancherla, D. Maiti, J. Am. Chem. Soc. 2014, 136, 13602-13605; d) K. M. Engle, T.-S. Mei, M. Wasa, J.-Q. Yu, Acc. Chem. Res. 2011, 45, 788-802.

[94] F. Yang, L. Ackermann, Org. Lett. 2013, 15, 718-720.

[95] S. E. Denmark, R. F. Sweis, Acc. Chem. Res. 2002, 35, 835-846. 
[96] a) H. Zhou, Y. H. Xu, W. J. Chung, T. P. Loh, Angew. Chem. Int. Ed. 2009, 48, 5355-5357;

b) A. F. Littke, G. C. Fu, Angew. Chem. Int. Ed. 2002, 41, 4176-4211.

[97] M.-Z. Lu, P. Lu, Y.-H. Xu, T.-P. Loh, Org. Lett. 2014, 16, 2614-2617.

[98] a) S. Zhao, B. Liu, B.-B. Zhan, W.-D. Zhang, B.-F. Shi, Org. Lett. 2016, 18, 4586-4589; b) H. Hachiya, K. Hirano, T. Satoh, M. Miura, Angew. Chem. Int. Ed. 2010, 122, 2248-2251.

[99] K. Shin, Y. Park, M.-H. Baik, S. Chang, Nat. Chem. 2018, 10, 218-224.

[100] a) P. Nareddy, F. Jordan, M. Szostak, Org. Biomol. Chem. 2017, 15, 4783-4788; b) P. Nareddy, F. Jordan, M. Szostak, ACS Catal. 2017, 7, 5721-5745; c) P. Nareddy, F. Jordan, M. Szostak, Chem. Sci. 2017, 8, 3204-3210.

[101] T. Yoshino, H. Ikemoto, S. Matsunaga, M. Kanai, Chem. Eur. J. 2013, 19, 9142-9146.

[102] a) M. Moselage, J. Li, L. Ackermann, ACS Catal. 2016, 6, 498-525; b) Z.-Z. Zhang, B. Liu, C.-Y. Wang, B.-F. Shi, Org. Lett. 2015, 17, 4094-4097; c) N. Sauermann, M. J. Gonzalez, L. Ackermann, Org. Lett. 2015, 17, 5316-5319.

[103] A. Y. Kocaman, B. Güven, Cytotechnology 2016, 68, 947-956.

[104] a) P.-X. Shen, X.-C. Wang, P. Wang, R.-Y. Zhu, J.-Q. Yu, J. Am. Chem. Soc. 2015, 137, 11574-11577; b) A. Deb, S. Bag, R. Kancherla, D. Maiti, J. Am. Chem. Soc. 2014, 136, 13602-13605; c) X.-C. Wang, Y. Hu, S. Bonacorsi, Y. Hong, R. Burrell, J.-Q. Yu, J. Am. Chem. Soc. 2013, 135, 10326-10329; d) S. HwiáLee, J. HwanáKwak, Y. HoonáJung, I. SuáKim, Chem. Commun. 2013, 49, 1654-1656; e) C. S. Yeung, X. Zhao, N. Borduas, V. M. Dong, Chem. Sci. 2010, 1, 331-336.

[105] a) W. Ma, P. Gandeepan, J. Li, L. Ackermann, Org. Chem. Front. 2017, 4, 1435-1467; b) B. Li, P. H. Dixneuf, Chem. Soc. Rev. 2013, 42, 5744-5767.

[105] a) B. M. Trost, Science 1991, 254, 1471-1477; b) B. M. Trost, Acc. Chem. Res., 2002, 35, 695-705; c) J. Wencel-Delord, F. Glorius, Nat. Chem. 2013, 5, 369-375; d) Z. Shi, C. Zhang, C. Tang, N. Jiao, Chem. Soc. Rev. 2012, 41, 3381-3430; e) A. J. Hickman, M. S. Sanford, Nature 2012, 484, 177-185; f) L. McMurray, F. O'Hara, M. J. Gaunt, Chem. Soc. Rev. 2011, $40,1885-1898$.

[107] a) P. Y. Choy, F. Y. Kwong, Org. Lett. 2013, 15, 270-273; b) G. Shan, X. Yang, L. Ma, Y. Rao, Angew. Chem. 2012, 124, 13247-13251; c) K. J. Stowers, A. Kubota, M. S. Sanford, 
Chem. Sci. 2012, 3, 3192-3195; d) D. Kalyani, M. S. Sanford, Org. Lett. 2005, 7, 4149-4152.

[108] a) Y.-F. Wang, H. Chen, X. Zhu, S. Chiba, J. Am. Chem. Soc. 2012, 134, 11980-11983; b) L. Zhang, G. Y. Ang, S. Chiba, Org. Lett. 2011, 13, 1622-1625.

[109] Q. Bu, T. Rogge, V. Kotek, L. Ackermann, Angew. Chem. Int. Ed. 2018, 57, 765-768.

[110] a) E. J.-G. Anctil, V. Snieckus, J. Organomet. Chem. 2002, 653, 150-160; b) J. Hassan, M. Sevignon, C. Gozzi, E. Schulz, M. Lemaire, Chem. Rev. 2002, 102, 1359-1470.

[111] T. Hiyama, Y. Hatanaka, Pure. Appl. Chem. 1994, 66, 1471-1478.

[112] a) J. C. Lewis, R. G. Bergman, J. A. Ellman, Acc. Chem. Res. 2008, 41, 1013-1025; b) D. Alberico, M. E. Scott, M. Lautens, Chem. Rev. 2007, 107, 174-238.

[113] S. Yang, B. Li, X. Wan, Z. Shi, J. Am. Chem. Soc. 2007, 129, 6066-6067.

[114] J. He, R. Takise, H. Fu, J.-Q. Yu, J. Am. Chem. Soc. 2015, 137, 4618-4621.

[115] N. Senthilkumar, K. Parthasarathy, P. Gandeepan, C. H. Cheng, Chem. Asian J. 2013, 8, 2175-2181.

[116] W. Song, L. Ackermann, Angew. Chem. Int. Ed. 2012, 124, 8376-8379.

[117] a) B. E. Haines, J.-Q. Yu, D. G. Musaev, Chem. Sci. 2018, 9, 1144-1154; b) Z. Shen, G. Cera, T. Haven, L. Ackermann, Org. Lett. 2017, 19, 3795-3798; c) G. Cera, T. Haven, L. Ackermann, Chem. Commun. 2017, 53, 6460-6463; d) G. Cera, T. Haven, L. Ackermann, Angew. Chem. Int. Ed. 2016, 55, 1484-1488; e) H.-L. Wang, M. Shang, S.-Z. Sun, Z.-L. Zhou, B. N. Laforteza, H.-X. Dai, J.-Q. Yu, Org. Lett. 2015, 17, 1228-1231.

[118] a) S. E. Denmark, J. H. C. Liu, Angew. Chem., Int. Ed. 2010, 49, 2978-2986; b) S. E. Denmark, C. S. Regens, Acc. Chem. Res. 2008, 41, 1486-1499.

[119] C.-L. Sun, B.-J. Li, Z.-J. Shi, Chem. Rev. 2010, 111, 1293-1314.

[120] a) R. Mei, J. Loup, L. Ackermann, ACS Catal. 2016, 6, 793-797; b) M. Moselage, N. Sauermann, J. Koeller, W. Liu, D. Gelman, L. Ackermann, Synlett 2015, 26, 1596-1600.

[121] a) J. R. Hummel, J. A. Ellman, Org. Lett. 2015, 17, 2400-2403; b) J. R. Hummel, J. A. Ellman, J. Am. Chem. Soc. 2014, 137, 490-498.

[122] a) P. Patel, S. Chang, ACS Catal. 2015, 5, 853-858; b) J. Park, S. Chang, Angew. Chem. Int. Ed. 2015, 54, 14103-14107.

[123] B. Sun, T. Yoshino, M. Kanai, S. Matsunaga, Angew. Chem. Int. Ed. 2015, 54, 12968-12972. 
[124] Y. Tatsuhiko, M. Shigeki, Adv. Synth. Catal. 2017, 359, 1245-1262.

[125] J.-Q. Wu, Z.-P. Qiu, S.-S. Zhang, J.-G. Liu, Y.-X. Lao, L.-Q. Gu, Z.-S. Huang, J. Li, H. Wang, Chem. Commun. 2015, 51, 77-80.

[126] a) S. Grimme, A. Hansen, J. G. Brandenburg, C. Bannwarth, Chem. Rev. 2016, 116, 5105-5154; b) J. P. Wagner, P. R. Schreiner, Angew. Chem. Int. Ed. 2015, 54, 12274-12296.

[127] D. Zell, Q. Bu, M. Feldt, L. Ackermann, Angew. Chem. Int. Ed. 2016, 128, 7534-7538.

[128] V. R. Kumar, B. Prabal, Eur. J. Org. Chem. 2016, 2016, 4059-4066.

[129] a) K. Raghuvanshi, D. Zell, L. Ackermann, Org. Lett. 2017, 19, 1278-1281; b) H. Wang, M. Moselage, M. J. González, L. Ackermann, ACS Catal. 2016, 6, 2705-2709; c) W. Ma, R. Mei, G. Tenti, L. Ackermann, Chem. Eur. J. 2014, 20, 15248-15251.

[130] S. Kozuch, S. Shaik, Acc. Chem. Res. 2010, 44, 101-110.

[131] O. Mahé, J. Desroches, J.-F. Paquin, Eur. J. Org. Chem. 2013, 2013, 4325-4331.

[132] B. Sun, T. Yoshino, S. Matsunaga, M. Kanai, Adv. Synth. Catal. 2014, 356, 1491-1495.

[133] B. Sun, T. Yoshino, S. Matsunaga, M. Kanai, Chem. Commun. 2015, 51, 4659-4661.

[134] D.-G. Yu, T. Gensch, F. de Azambuja, S. Vásquez-Céspedes, F. Glorius, J. Am. Chem. Soc. 2014, 136, 17722-17725.

[135] V. K. Tiwari, N. Kamal, M. Kapur, Org. Lett. 2015, 17, 1766-1769.

[136] K. Shibata, N. Hasegawa, Y. Fukumoto, N. Chatani, ChemCatChem 2012, 4, 1733-1736.

[137] E. V. Bellale, D. S. Bhalerao, K. G. Akamanchi, J. Org. Chem. 2008, 73, 9473-9475.

[138] S. Rakshit, C. Grohmann, T. Besset, F. Glorius, J. Am. Chem. Soc. 2011, 133, 2350-2353. 


\section{Acknowledgements}

At the outset, I would like to express my sincerely thanks to Prof Dr. Lutz Ackermann, who is patience, intelligent, professional and gentleman. In the past 4 years, He gave me a lot of professional guidance, which let me get a lot benefit on the rugged road of scientific research. He is always full of energy to everything, I see a great chemist from him.

I am grateful to PD Dr. Alexander Breder, as my second supervisor. His kindly support provided me with a great deal of motivation. Great gratitude for Prof. Dr. Dr. h.c. Lutz-F. Tietze, Prof. Dr. Dietmar Stalke, Dr. Shoubhik Das, Dr. Franziska Thomas, who have agreed to attend my defense.

I deeply appreciate my great motherland- China and also the China Scholarship Council (CSC) for the financial support during my phd study in Germany.

I would like to thank Dr. Gandeepan Parthasarathy, Dr. Mélanie Lorion, Dr. Santhi Vardhana Yetra, Dr. Joao Carlos Agostinho de Oliveira, Dr. Elżbieta Gońka, Hui Wang, Joachim Loup, Torben Rogge, for their patience and kindness to correct this manuscript.

I also would like to thank Mrs. Gabriele Keil-Knepel, who is very nice and kindness. She always gave me some help when i encountered any problem in last 4 years. Her kindly smile warmed my heart deeply. I thank Mr. Stefan Beußhausen and Mr. Karsten Rauch for the invaluable technical and experimental assistance. I would like to thanks all the members of the analytical departments.

I am also deeply indebted to all my enthusiastic lab mates-Dr. Gandeepan Parthasarathy, Dr. Elżbieta Gońka, Wei Wang, Michaela Bauer, Alexandra Schischko, Nikolaos Kaplaneris-in lab 302 for their help and encouragement in past 4 years. I also thank to Dr. Vladislav Kotek and Dr. Hongjun Ren, they gave me some adivices about my research.

I am grateful to all the other people in the last 4 years duing my study. I have enjoyed very nice together with the whole group members.

During this 4 years, I also enjoyed the free time with my chinese collegues and friends - Dr. Hongjun Ren, Dr. Xu Tian, Dr. Wenbo Ma, Dr. Jie Li, Dr. Fanzhi Yang, Dr. Yingjun Zhu, Dr. 
Weiping Liu, Dr. Ruhuai Mei, Dr. Zhixiong Ruan, Dr. Yufeng Liang, Dr. Weijun Kong, Dr. Youai Qiu, Hui Wang, Wei Wang, Cuiju Zhu, Cong Tian, Jiayu Mo, Shoukun Zhang, Zhigao Shen, Long Yang, Xiaohua Qi, Jiliang Li. Mengwen Hu, Mengdan Liu. Thank you for all your support and encouragement.

At last, sepical thanks to my husband Mr Shuxue Tan who always encourages me to overcome difficulties and chanllenges. He is always there for me.

I will dedicate this thesis to my family!

Qingqing Bu (卜庆青) 


\section{Curriculum Vitae}

\section{Personal information}

Name: $\quad$ Qingqing Bu

Date of Birth: $\quad 19.02,1988$

Place of Birth: $\quad$ Xinxiang, Henan (P. R. CHINA.)

Gender: $\quad$ Female

Nationality: Chinese

2. Education

10.2014-Present

PhD Candidate in Organic Chemistry

Institut für Organische und Biomolekulare Chemie,

Georg-August-Universität Göttingen

Supervisor: Prof. Dr. Lutz Ackermann

Thesis: Ruthenium- and Cobalt-Catalyzed C-H Activation

2011.09-2014.06

M. Sc. in Fine Chemicals

State Key Laboratory of Fine Chemicals,

Dalian University of Technology 
Supervisor: Prof. Dr. Chun Liu

Thesis: The oxidation of arylaldehydes in EtOH under metal-free

conditions

09.2006-07.2010

B.Sc. in Chemical Engineering and Technology

College of Chemistry,

Henan Normal university

\section{Publication}

1) Q. Bu,' T. Rogge,' V. Kotek, L. Ackermann, "Distal Weak Coordination of Acetamides in Ruthenium(II)-Catalyzed C-H Activation Processes" Angew. Chem. Int. Ed. 2018, 57, 765-768. 'Both authors contributed equally.

2) D. Zell,' Q. Bu,' M. Feldt, L. Ackermann, "Mild C-H/C-C Activation by (Z)-Selective Cobalt-Catalysis" Angew. Chem. Int. Ed. 2016, 55, 7408-7412. 'Both authors contributed equally.

3) Cobalt-catalyzed $\mathrm{C}-\mathrm{H}$ arylations. Manuscript is in preparation.

4) Ruthenium-catalyzed C-H oxygenations. Manuscript is in preparation.

5) A conference paper (accepted by The 13th National homogeneous catalysis symposium, 09. 2013, Suzhou).

6) A patent Applications has been granted, Chinese Patent Application No: CN103613479A. 


\section{Erklärung}

Ich versichere, dass ich die vorliegende Dissertation in dem Zeitraum von Oktober 2014 bis Oktober 2018 am Institut für Organische und Biomolekulare Chemie der GeorgAugust-Universität Göttingen

auf Anregung und unter Anleitung von

Herrn Prof. Dr. Lutz Ackermann

selbstständig verfasst und keine anderen als die angegebenen Hilfsmittel und

Quellen verwendet habe.

Göttingen, den 20.09.2018 